$S$

\begin{tabular}{|c|c|c|c|c|}
\hline \multirow{3}{*}{$\begin{array}{l}\text { 2. ECN Category } \\
\text { (mark one) } \\
\text { Supplemental } \\
\text { Direct Revision } \\
\text { Change ECN } \\
\text { Temporary } \\
\text { Standby } \\
\text { Supersedure } \\
\text { Cancel/Void }\end{array}$} & \multirow{3}{*}{$\begin{array}{c}{[]} \\
{[\mathbf{x}]} \\
{[]} \\
{[]} \\
{[]} \\
{[]} \\
{[]}\end{array}$} & $\begin{array}{l}\text { 3. Originator's Name, Organization, MSIN, } \\
\text { and Telephone No. } \\
\text { P. D. Rittmann, Nuclear Safety, } \\
\text { R3-26, 373-7794 }\end{array}$ & $\begin{array}{l}\text { 4. USQ Required? } \\
\text { [] Yes }[x] \text { No }\end{array}$ & $\begin{array}{l}\text { 5. Date } \\
5-26-90\end{array}$ \\
\hline & & $\begin{array}{l}\text { 6. Project Title/No./Work Order No. } \\
\text { Spent Nuclear Fuel Project }\end{array}$ & $\begin{array}{l}\text { 7. Bldg./Sys./Fac. No. } \\
\text { W-441 }\end{array}$ & $\begin{array}{l}\text { 8. Approval Designator } \\
\qquad E, S^{N}, Q\end{array}$ \\
\hline & & $\begin{array}{l}\text { 9. Document Numbers Changed by this ECN } \\
\text { (includes sheet no. and rev.) } \\
\text { HNF-SD-SNF-TI-059, Rev. } 1\end{array}$ & $\begin{array}{l}\text { 10. Related ECN No(s). } \\
637174\end{array}$ & $\begin{array}{l}\text { 11. Related PO No. } \\
\text { N/A }\end{array}$ \\
\hline
\end{tabular}

12a. Modification Work
[ ] Yes (fill out Blk. 12b)
[x] No (NA Blks. 12b, 12c, 12d)

13a. Description of Change

\begin{tabular}{|c|c|}
\hline $\begin{array}{l}\text { 12b. Work Package } \\
\text { No. }\end{array}$ & $\begin{array}{l}\text { 12c. Modification Work Complete } \\
\text { N/A }\end{array}$ \\
\hline N/A & $\begin{array}{c}\text { Design Authority/Cog. Engineer } \\
\text { Signature \& Date }\end{array}$ \\
\hline
\end{tabular}

12d. Restored to Original Condition (Temp. or Standby ECN only)

N/A

Design Authority/Cog. Engineer Signature \& Date

This new revision shows joint frequency tables and wind roses for the 100 and 200 Areas of the Hanford Site using the average of nine years of data (1983 to 1991). Revision includes the overall site $95 \%$ values for air transport factors. Distances have been revised in each direction to follow the method given in NRC Regulatory Guide 1.145.

\begin{tabular}{|lcllllll}
\hline 14a. Justification (mark one) & & & & & \\
Criteria Change & {$[\mathrm{x}]$} & Design Improvement & {[]} & Environmental & [ ] & Facility Deactivation \\
As-Found & {[]} & Facilitate Const & {[]} & Const. Error/Omission & [] & Design Error/Omission & [] \\
\hline
\end{tabular}

14b. Justification Details

See box 13a.

15. Distribution (include name, MSIN, and no. of copies)

See attached distribution coversheet.

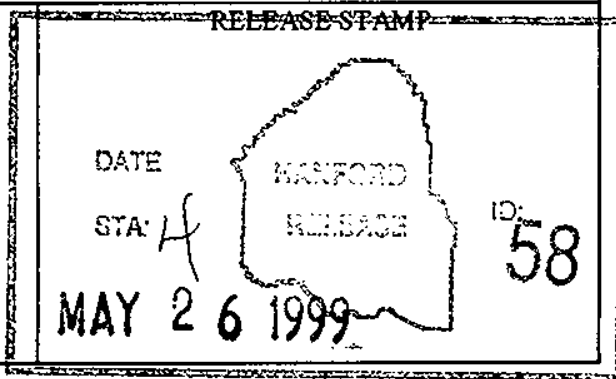




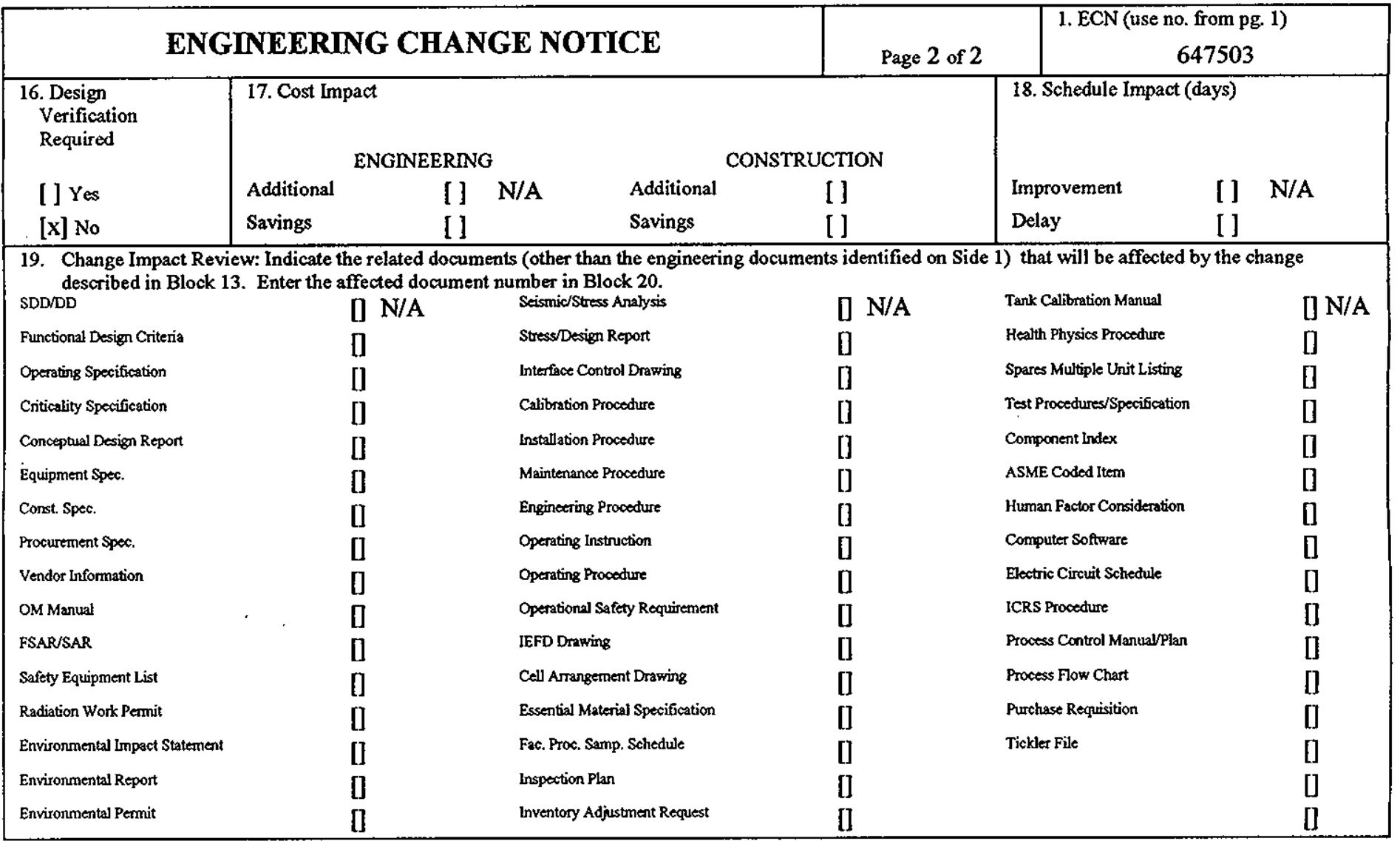

20. Other Affected Documents: (NOTE: Documents listed below will not be revised by this ECN.) Signatures below indicate that the signing organization has been notified of other affected documents listed below.

Document Number/Revision

Document Number/Revision

Document Number Revision

N/A

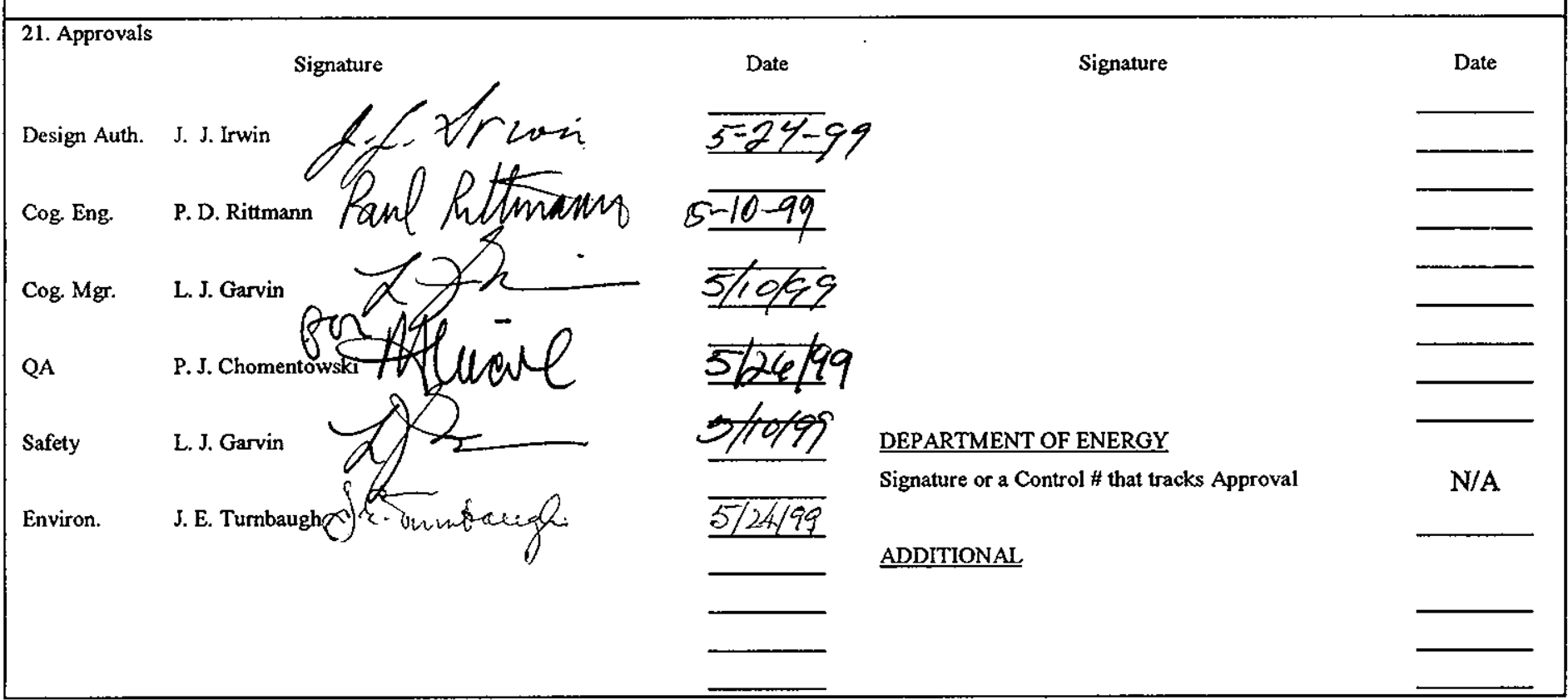




\section{DISTRIBUTION SHEET}

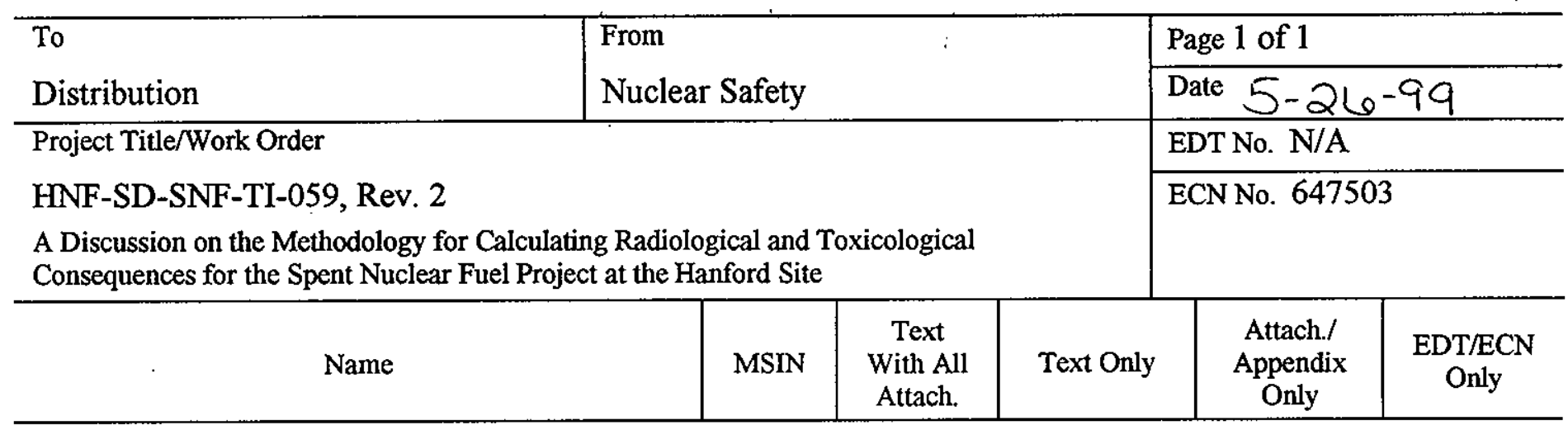

J. R. Brehm

P. J. Chomentowski

R. D. Crowe

L. J. Garvin

S. B. Harrington (3)

J. J. Irwin

M. A. Medsker

M. G. Piepho

T. B. Powers

P. D. Rittmann (2)

J. E. Turnbaugh

SNF Project Files
R3-26 X

S2-48 X

R3-26 $X$

R3-26 X

R3-26 $X$

R3-86 $X$

R3-26 $X$

R3-26 $\mathrm{X}$

R3-26 $X$

R3-26 $X$

R3-26 $X$

R3-11 X 


\section{A Discussion on the Methodology for Calculating Radiological and Toxicological Consequences for the Spent Nuclear Fuel Project at the Hanford Site}

\section{P. D. Rittmann}

Fluor Daniel Northwest, Inc., Richland, WA 99352

U.S. Department of Energy Contract DE-AC06-96RL13200

ECN: 647503

Org Code: $2 \mathrm{~F} 200$

B\&R Code: 39EW40400
UC: 620

Charge Code: 105350/CB80

Total Pages: 194

Key Words: environmental, air transport, inhalation dose, toxic chemical, air concentration

Abstract: This report contains technical information used to determine accident consequences for the Spent Nuclear Fuel Project safety documents. It does not determine accident consequences or describe specific accident scenarios, but instead provides generic information used to calculate radiological consequences and toxicological exposures for postulated accident releases.

TRADEMARK DISCLAIMER. Reference herein to any specific commercial product, process, or service by trade name, trademark, manufacturer, or otherwise, does not necessarily constitute or imply its endorsement, recommendation, or favoring by the United States Government or any agency thereof or its contractors or subcontractors.

Printed in the United States of Anerica. To obtain copies of this document, contact: Document Control Services, P.O. Box 950, Mailstop H6-08, Richland WA 99352, Phone (509) 372-2420; Fax (509) 376-498
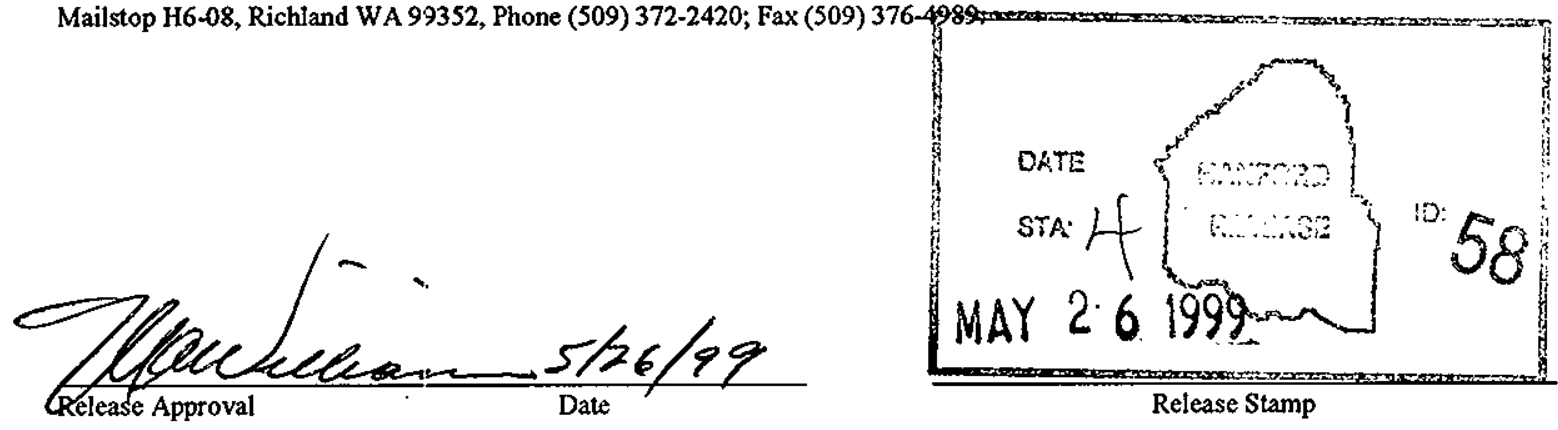
Rev. 2

(2) Title

A Discussion on the Methodology for Calculating Radiological and Toxicological Consequences for the Spent Nuclear Fuel Project at the Hanford Site

\begin{tabular}{|c|c|c|c|}
\hline \multicolumn{4}{|c|}{ CHANGE CONTROL RECORD } \\
\hline \multirow[t]{2}{*}{ (3) Revision } & \multirow[t]{2}{*}{ (4) Description of Change - Replace, Add, and Delete Pages } & \multicolumn{2}{|c|}{ Authorized for Release } \\
\hline & & (5) Cog. Engr. & (6) Cog. Mgr. \\
\hline & $(7)$ & & \\
\hline 0 & EDT: 607699 & & \\
\hline 1 & $\begin{array}{l}\text { ECN: } 637174 \\
\text { Revision } 1 \text { adds a comparison of radiological and toxicological } \\
\text { exposures showing that radiological consequences are always } \\
\text { worse. Revision also adds air transport factors for stack } \\
\text { emissions. The maximum onsite exposure time was changed } \\
\text { from } 8 \text { hours to } 12 \text { hours, to be consistent with the current } \\
\text { Hanford practice. }\end{array}$ & & \\
\hline$R^{2}$ & $\begin{array}{l}\text { ECN: } 647503 \\
\text { Revision } 2 \text { shows joint frequency tables and wind roses for the } \\
100 \text { and } 200 \text { Areas of the Hanford Site using the average of nine } \\
\text { years of data (1983 to } 1991) \text {. Revision includes the overall site } \\
95 \% \text { values for air transport factors. Distances have been } \\
\text { revised in each direction to follow the method given in NRC } \\
\text { Regulatory Guide } 1.145 \text {. }\end{array}$ & $\begin{array}{l}\text { P.D. Rittmann } \\
\text { Paul RWtwam } \\
5 / 10 / 99\end{array}$ & L. J. Garvin \\
\hline & & & \\
\hline & & & \\
\hline & & & \\
\hline & & & \\
\hline
\end{tabular}


HNF-SD-SNF-TI-059 REV 2

This page intentionally left blank. 


\section{CONTENTS}

1.0 PURPOSE

2.0 AIR TRANSPORT FACTORS . . . . . . . . . . . . . . . . . . . 2-1

2.1 GENERATION OF AIR TRANSPORT FACTORS . . . . . . . . . . 2-1

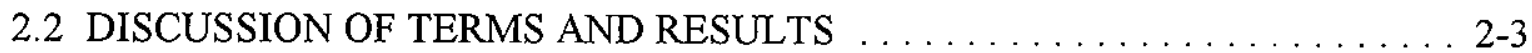

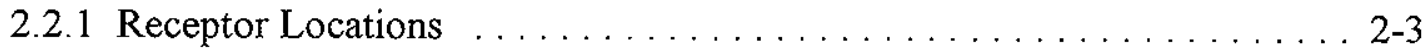

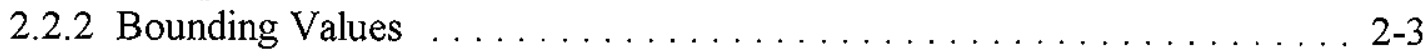

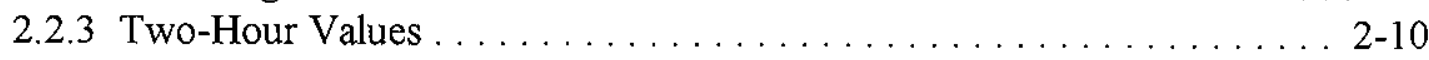

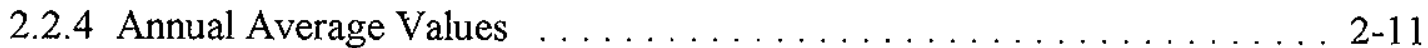

2.2.5 Interpolated Values ........................... 2-12

2.2.6 Puff Release Values for Toxicological Releases $\ldots \ldots \ldots \ldots \ldots \ldots$. 2-13

3.0 RADIOLOGICAL CONSEQUENCE METHODOLOGY $\ldots \ldots \ldots \ldots \ldots \ldots \ldots$. $\ldots$. 1

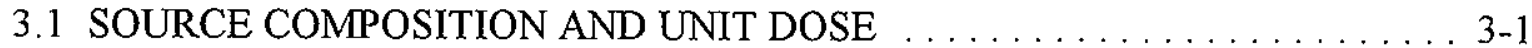

3.2 RADIOLOGICAL EXPOSURE PATHWAYS . . . . . . . . . . . . . 3-12

3.2 .1 Inhalation Pathway . . . . . . . . . . . . . . . . . . . . . . 3-12

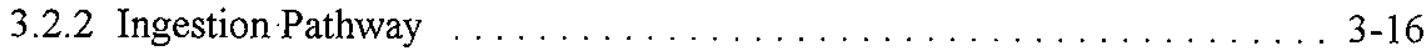

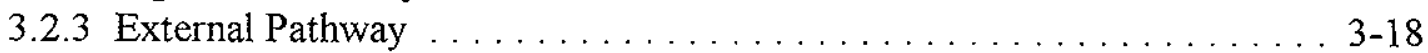

3.3 DOSE CALCULATION METHODS . . . . . . . . . . . . . . . . . . . . . . 3-19

4.0 TOXICOLOGICAL CONSEQUENCE METHODOLOGY . . . . . . . . . . . . . . 4-1

4.1 SOURCE COMPOSITION . . . . . . . . . . . . . . . . . . . . . . 4-1

4.2 TOXICOLOGICAL EXPOSURE PATHWAYS . . . . . . . . . . . . . 4-6

4.3 TOXICOLOGICAL DOSE CALCULATION METHODS . . . . . . . . . 4-6

5.0 COMPARISON OF TOXICOLOGICAL AND

RADIOLOGICAL IMPORTANCE . . . . . . . . . . . . . . . . . . . . 5-1

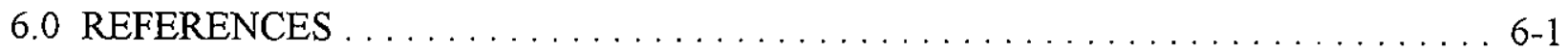


HNF-SD-SNF-TI-059 REV 2

\section{CONTENTS (Continued)}

\section{APPENDIXES}

A GROUND-LEVEL AIR TRANSPORT FACTORS FOR EACH WIND DIRECTION

B GXQ INPUT FILES FOR GROUND-LEVEL RELEASES . . . . . . . . . . B-1

C AIR TRANSPORT FACTORS FOR ELEVATED RELEASES $\ldots \ldots \ldots \ldots \ldots \ldots$. . .

D GXQ INPUT FILES FOR ELEVATED RELEASES $\ldots \ldots \ldots \ldots \ldots \ldots \ldots \ldots$

E JOINT FREQUENCY DATA AND WIND ROSES $\ldots \ldots \ldots \ldots \ldots \ldots \ldots$

F UNIT DOSE WITH INSOLUBLE LUNG CLASSES $\ldots \ldots \ldots \ldots \ldots \ldots \ldots \ldots$

G GENII INPUT FILES FOR INGESTION DOSE CALCULATIONS $\ldots \ldots \ldots \ldots$. . . 1

$\mathrm{H}$ CHECKLISTS FOR PEER REVIEW AND APPROVAL $\ldots \ldots \ldots \ldots \ldots \ldots \ldots$ 
HNF-SD-SNF-TI-059 REV 2

\section{LIST OF TABLES}

1-1 Radiological Dose Limits/Guidelines for the Spent Nuclear Fuel Project $\ldots \ldots \ldots \ldots$. 1-2

1-2 Toxicological Air Concentration Guidelines for the Spent Nuclear Fuel Project . . . . 1-2

2-1 Distances (meters) in Each Wind Transport Direction for the Canister Storage

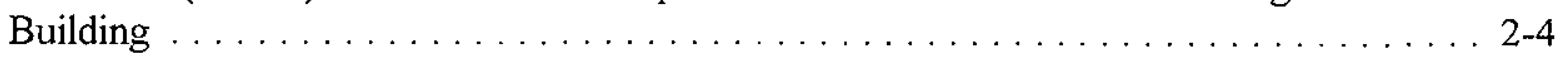

2-2 Distances (meters) in Each Wind Transport Direction for the Cold Vacuum

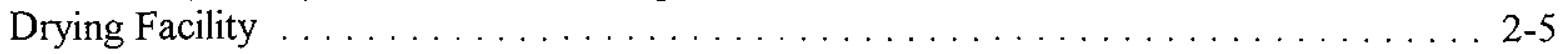

2-3 Distances (meters) in Each Wind Transport Direction for the $100 \mathrm{KW}$ Reactor Building . 2-6

2-4 Maximum Individual Locations and Air Transport Factors for Ground-Level Releases . . 2-7

2-5 Maximum Individual Locations and Air Transport Factors for Stack Releases . . . . . . . 2-9

2-6 Air Transport Factors for Puffs and Puff-to-Plume Transition Times . . . . . . . . 2-14

3-1 Radionuclide Composition of Fuel and the Unit Dose Factor $\ldots \ldots \ldots \ldots \ldots$. . . . . .

3-2 Organ Dose Factors from Inhalation and Air Submersion Dose Factors . . . . . . . . 3-6

3-3 Unit Dose Factors for Organs and for Air Submersion $\ldots \ldots \ldots \ldots \ldots \ldots \ldots \ldots \ldots$

3-4 Unit Dose Factor for 24-Hour Exposure to the Offsite Maximum Exposed Individual . . 3-19

3-5 Effective Dose Equivalent in Sieverts from One-Gram Uranium Fuel Releases . . . . . 3-22

3-6 Minimum Releases to Reach the Radiological Risk Guidelines . . . . . . . . . . . . . 3-23

4-1 Composition of Spent Fuel and Air Concentration Limits . . . . . . . . . . . . . 4-2

4-2 Ratios of Normalized Fuel Composition to Risk Guidelines $\ldots \ldots \ldots \ldots$. . . . . 4-4

4-3 Composition-Weighted Risk Guidelines for Spent Fuel . . . . . . . . . . . . 4-5

4-4 Composition-Weighted Air Concentration Guidelines for Spent Fuel $\ldots \ldots \ldots \ldots$. . . . .

4-5 Maximum Sum-of-Fractions for a One-Gram Uranium Fuel Release at Ground Level . . 4-11

4-6 Minimum Releases to Reach the Toxicological Risk Guidelines . . . . . . . . . . . 4-12

5-1 Radiological Ratios Divided by Toxicological Ratios $\ldots \ldots \ldots \ldots \ldots \ldots \ldots$ 5-2 


\section{LIST OF TERMS}

$\begin{array}{ll}\text { CSB } & \text { Canister Storage Building } \\ \text { CVDF } & \text { Cold Vacuum Drying Facility } \\ \text { CWRG } & \text { composition-weighted risk guideline } \\ \text { DBA } & \text { design basis accident } \\ \text { DOE } & \text { U.S. Department of Energy } \\ \text { DOE-RL } & \text { U.S. Department of Energy, Richland Operations Office } \\ \text { EDE } & \text { effective dose equivalent } \\ \text { ERPG } & \text { emergency response planning guideline } \\ \text { HEPA } & \text { high-efficiency particulate air (filter) } \\ \text { HVAC } & \text { heating, ventilation, and air conditioning } \\ \text { NRC } & \text { U.S. Nuclear Regulatory Commission } \\ \text { PEL } & \text { permissible exposure limit } \\ \text { SNF } & \text { spent nuclear fuel } \\ \text { TWA } & \text { time-weighted average }\end{array}$


HNF-SD-SNF-TI-059 REV 2

\title{
A DISCUSSION ON THE METHODOLOGY FOR CALCULATING RADIOLOGICAL AND TOXICOLOGICAL CONSEQUENCES FOR THE SPENT NUCLEAR FUEL PROJECT AT THE HANFORD SITE
}

\author{
by Paul D. Rittmann, PhD CHP
}

\subsection{PURPOSE}

This report contains technical support information used to determine accident consequences for the Spent Nuclear Fuel (SNF) Project safety documents. It does not determine accident consequences or describe specific accident scenarios, but instead provides generic information used to calculate radiological doses and air concentrations of toxic chemicals for postulated accident releases from SNF facilities.

Both radionuclides and toxic chemicals may be released into the air through postulated accidents and then travel downwind to other onsite workers and offsite to members of the public. Section 2.0 provides the methodology for modeling the air transport of airborne materials. It contains air transport factors that were generated for the locations of the SNF Project facilities in the 200 East Area and in the $100 \mathrm{~K}$ Area. Guidance is provided on the appropriate selection and use of these air transport factors for calculating accident consequences.

Specific modeling assumptions and methods for radiological emissions are presented in Section 3.0. This section lists radionuclide inventories for high-burnup Mark IV fuel. This inventory is developed into a unit dose for calculating accident consequences (i.e., dose equivalent) from radionuclides released into the air. Calculated radiological doses are evaluated by comparison with guidance from U.S. Department of Energy, Richland Operations Office (DOE-RL). Postulated accidents that lead to doses exceeding the guidelines require mitigation.

The method for calculating air concentrations of toxic chemicals is presented in Section 4.0. This section lists chemical inventories for high-burnup Mark IV fuel and a discussion of other potential chemical emission hazards. This inventory is developed into a unit sum-offractions for evaluating toxicological hazards presented by specific mixtures of the chemicals found in spent fuel. Calculated air concentrations are evaluated by comparison with guidance from DOE-RL. Postulated accidents that lead to air concentrations exceeding the guidelines require mitigation.

Section 5.0 compares the radiological and the toxicological consequences of postulated accidents using a ratioing approach in which doses and air concentrations are compared with the corresponding DOE-RL guidance. It is shown that the radiological guidelines are always more limiting than the toxicological guidelines. For this reason, the accident analyses need only examine the radiological effects. 
The U.S. Department of Energy (DOE)-recommended risk evaluation guidelines (Sellers 1997) for radiological consequences and for toxicological exposures are shown in Tables $1-1$ and 1-2 below.

Table 1-1. Radiological Dose Limits/Guidelines for the Spent Nuclear Fuel Project.

\begin{tabular}{|c|c|c|}
\hline Frequency & Onsite, Sv (rem) & Offsite, Sv (rem) \\
\hline Anticipated & $0.01 \mathrm{~Sv}$ & $0.005 \mathrm{~Sv}$ \\
$10^{+0}$ to $10^{-2} / \mathrm{yr}$ & $0.0 \mathrm{rem})$ & $(0.5 \mathrm{rem})$ \\
\hline Unlikely & $\begin{array}{c}10 \mathrm{~Sv} \\
10^{-2} \text { to } 10^{-4} / \mathrm{yr}\end{array}$ & $\begin{array}{c}\text { (1) }) \\
(5.0 \mathrm{rem})\end{array}$ \\
\hline Extremely unlikely & $0.25 \mathrm{~Sv}$ & $0.05 \mathrm{~Sv}$ \\
$10^{-4}$ to $10^{-6} / \mathrm{yr}$ & $(25 \mathrm{rem})$ & $(5.0 \mathrm{rem})$ \\
\hline
\end{tabular}

$1 \mathrm{~Sv}=100 \mathrm{rem}$.

The doses are 50 year committed effective dose equivalents.

Onsite values are "risk evaluation guidelines," while offsite values are "accident release limits"

(Sellers 1997).

Table 1-2. Toxicological Air Concentration Guidelines for the Spent Nuclear Fuel Project.

\begin{tabular}{|c|c|c|}
\hline Frequency & Onsite & Offsite \\
\hline $\begin{array}{c}\text { Anticipated } \\
10^{+0} \text { to } 10^{-2} / \mathrm{yr}\end{array}$ & $\leq$ ERPG-1 & $\leq$ PEL-TWA \\
\hline $\begin{array}{c}\text { Unlikely } \\
10^{-2} \text { to } 10^{-4} / \mathrm{yr}\end{array}$ & $\leq$ ERPG-2 & $\leq$ ERPG-1 \\
\hline $\begin{array}{c}\text { Extremely unlikely } \\
10^{-4} \text { to } 10^{-6} / \mathrm{yr}\end{array}$ & $\leq$ ERPG-3 & $\leq$ ERPG-2 \\
\hline
\end{tabular}

$\mathrm{ERPG}=$ emergency response planning guideline.

PEL = permissible exposure limit.

TWA $=$ time-weighted average.

The following are definitions for emergency response planning guidelines (ERPGs) and the permissible exposure limit (PEL)-time-weighted average (TWA) (AIHA 1991).

- The ERPG-1 value is the maximum airborne concentration to which it is believed that nearly all individuals could be exposed for up to 1 hour without experiencing other than mild transient adverse health effects or perceiving a clearly defined objectionable odor. 
- The ERPG-2 value is the maximum airborne concentration to which it is believed that nearly all individuals could be exposed for up to 1 hour without experiencing or developing irreversible or other serious health effects or symptoms that could impair their abilities to take protective action.

- The ERPG-3 value is the maximum airborne concentration to which it is believed that nearly all individuals could be exposed for up to 1 hour without experiencing or developing life-threatening health effects.

- The PEL-TWA value is the employees' average airborne exposure in any 8-hour work shift of a 40 -hour work week that shall not be exceeded.

PEL-TWA use for emergency response is not strictly appropriate because the PEL-TWA is designed to control relatively long-term worker exposure rather than the short term exposure to the public that would be expected for accident response. The lower of the ERPG-1 and the PEL-TWA should be used for the offsite exposure for high frequency events. Use of the limits that are at or below the ERPG-1 accident category provides an additional level of conservatism. However, it is shown in Section 5.0 that radiological effects are greater than toxicological effects, so this refinement is not needed.

No published ERPG values exist for a number of chemicals found in SNF. Therefore ERPG values developed by Craig to fill these gaps were employed (Craig 1997). These interim ERPG values are known as temporary emergency exposure limits or TEELs. 
HNF-SD-SNF-TI-059 REV 2

This page intentionally left blank. 


\subsection{AIR TRANSPORT FACTORS}

\subsection{GENERATION OF AIR TRANSPORT FACTORS}

In this report, the air transport factors $\left(\chi / Q^{\prime}\right.$ and $\left.\chi / Q\right)$ represent the dilution of a contaminant by atmospheric turbulence and diffusion as the contaminant travels downwind. Two types of air transport factors are needed to represent both dose and air concentration.

The symbol $\chi / Q^{\prime}$ is the time-integrated normalized air concentration at a downwind receptor location. It can also be regarded as the ratio of the average air concentration measured at the downwind receptor to the average release rate measured at the release point. It is used to determine radionuclide doses and noncorrosive chemical concentrations at downwind locations. The primary indicator of harm to the receptor is the amount that accumulates in the body via inhalation or skin absorption rather than the actual air concentration during the passage of the plume. The methods described in NRC Regulatory Guide 1.145, Atmospheric Dispersion Models for Potential Accident Consequence Assessments at Nuclear Power Plants are followed for ground level emissions. However, for stack emissions affected by nearby buildings (i.e., the Cold Vacuum Drying Facility [CVDF] and Canister Storage Building [CSB] heating, ventilation, and air conditioning [HVAC] stacks), this regulatory guide provides no specific direction, so a simple model was developed to extend the U.S. Nuclear Regulatory Commission (NRC) model to represent expected phenomena.

The symbol $\chi / Q$ is the normalized peak air concentration, that is, the peak air concentration at the center of a puff divided by the quantity released. It is used to determine the consequences to a receptor for toxic chemicals that are corrosive. The actual concentration is the primary indicator of harm to the receptor rather than the amount that accumulates in the body during plume passage. NRC Regulatory Guide 1.145 does not address air concentrations, so a simple puff model was developed to represent expected effects. Some aspects of the NRC regulatory model are preserved.

For both types of air transport factors, a realistic worst case model is developed for the accident analyses. The worst observed wind conditions are not selected. Instead, the hourly wind data collected at a given location are used to construct a distribution of potential values for a given wind direction, and also for the entire boundary. As recommended by the NRC Regulatory Guide 1.145 , values which are exceeded only $0.5 \%$ of the time for each wind direction, or $5.0 \%$ of the time for the entire boundary, are selected. For SNF facilities the sector maximum $(0.5 \%)$ is always greater than the overall site value $(5.0 \%)$ for ground-level emissions. Tables of sector and site air transport factors are provided in Appendix A for ground-level emissions and in Appendix $\mathrm{C}$ for elevated emissions.

The computer program GXQ (WHC-SD-GN-SWD-30002 and WHC-SD-GN-SWD-30003) was used to generate $\chi / Q^{\prime}$ and $\chi / Q$ values. Input files for the GXQ program are provided in Appendix B for ground-level releases and in Appendix $D$ for elevated releases. The joint frequency data used are 9-year averaged data from the years 1983 through 1991. The data used to represent $100 \mathrm{~K}$ Area winds were collected at the meteorology tower 
located between the $100 \mathrm{~N}$ and $100 \mathrm{~K}$ Areas $(100 \mathrm{~N})$. The data used to represent 200 East Area winds were obtained east of the 200 West Area (Hanford Meteorological Station). These values are listed in Appendix $\mathrm{E}$ for reference.

Unlike many air transport computer programs, GXQ has the ability to represent both the height of the release and the height of the receptor. Traditional ground-level release models assume the release height is zero meters, and the receptor is also breathing air from a height of zero meters. This unrealistic model is adequate at large distances, where elevations of a few meters for the release or the receptor location do not affect the result. However, at the onsite location $(100 \mathrm{~m})$ for stability class $\mathrm{G}$, this unrealistic assumption has the effect of doubling the result. The doubling comes about by including the ground reflection factor. For class $\mathrm{G}$ conditions, the vertical spread of the plume is small enough that reflection is insignificant at $100 \mathrm{~m}$ downwind for release and receptor heights of $2 \mathrm{~m}$. To be consistent with the formulas given in NRC Regulatory Guide 1.145, as well as previous Hanford Site practice, this feature was not used.

GXQ, Version 4.0 (WHC-SD-GN-SWD-30002), is a FORTRAN program for calculating atmospheric dispersion using site specific wind data. It uses the Gaussian straight line model for both instantaneous and continuous releases. Several models are available that modify parameters within the Gaussian plume model to account for phenomena such as plume depletion, building wake, plume meander, gravitational settling, and plume rise. The treatment of site wind data is also subject to user controls to allow various frequencies of exceedence to be computed. GXQ is an expert program. This means that it is intended to be used by individuals who are knowledgeable of the limits and applicability of the models implemented. The program has been reviewed and tested to verify that it implements its calculational models correctly (WHC-SD-GN-SWD-30003). In addition, since GXQ can duplicate GENII (PNL-6584) air transport results, it has been checked against the GENII software.

Air transport factors have been computed for three release durations: very short, 2 hours, and annual average. These are derived from NRC Regulatory Guide 1.145. Annual average is the largest time interval. The 2-hour case is needed to calculate air transport factors for release durations between 2 hours and 1 year using the method given in NRC Regulatory Guide 1.145. The very short duration case looks at a time scale short enough that the corrections and averaging used in the 2-hour case cannot be assumed. In the discussion below, the very short duration case is considered bounding. For ground level releases, "very short" means less than one hour. For stack releases, "very short" means less than 30 minutes. For toxicological calculations, the "puff" model would normally used for very short duration emissions. In the puff model, the meaning of "very short" depends on the transport distance. Further discussion is provided below. 


\subsection{DISCUSSION OF TERMS AND RESULTS}

\subsubsection{Receptor Locations}

Each of the principal receptors locations (onsite or offsite) has a unique value for air transport factor. Several locations have been selected in order to identify the locations with the largest air transport factors. Because both the radiological dose and the toxicological concentration are directly proportional to the air transport factor, the consequences of a release are greatest at the location with the greatest air transport factor.

Onsite workers are assumed to be located no closer than $100 \mathrm{~m}$ from the release point. These individuals are part of the Hanford Site workforce not directly involved with SNF activities. Onsite members of the public are assumed to be located on the Columbia River or Highway 240, which represent the nearest public access locations for SNF facilities. Receptor locations in all 16 wind directions must be evaluated to identify the location with the greatest air transport factor. An additional onsite receptor location for $100 \mathrm{~K}$ Area releases is the 100 Area Fire Station $(3,750 \mathrm{~m} \mathrm{ESE})$. Other onsite locations (e.g., the $100-\mathrm{N}$ reactor) are not evaluated because the nearest onsite worker location (at $100 \mathrm{~m}$ ) will receive substantially higher consequences from any release.

Offsite receptors are located on the Hanford Site boundary. To the north this boundary is the Wahluke slope, consistent with guidance from DOE-RL (Sellers 1996). Receptor locations in all 16 wind directions must be evaluated to identify the location with the greatest air transport factor.

Distances from the three SNF Project facilities (CSB, CVDF, and 100-KW reactor building) to public access locations (onsite and offsite) in all 16 wind transport directions are shown in Tables 2-1, 2-2, and 2-3. In each table, the distances to the nearest public access locations onsite, as well as to the Hanford Site boundary, are shown for two methods. The first method is that specified in NRC Regulatory Guide 1.145, which uses the shortest distance in a 45-degree sector centered on the direction of interest. These values are incorporated into air transport calculations. The second method is provided to show changes from Revision 1 of this document. This method finds the shortest distance in the sector of interest (i.e., 22.5 degrees centered on the direction of interest). The NRC method can lead to considerably smaller values if the distance to the boundary is changing rapidly with wind transport direction.

\subsubsection{Bounding Values}

Table 2-4 shows the bounding $\chi / Q^{\prime}$ values for onsite and offsite receptors for continuous ground-level releases under the column heading " $<1 \mathrm{hr} "$. These $\chi / \mathrm{Q}^{\prime}$ values should be used for ground-level releases less than 1 hour in duration. The 1-hour cutoff comes from NRC Regulatory Guide 1.145. Releases lasting less than I hour are modeled as point sources. 
Table 2-1. Distances (meters) in Each Wind Transport Direction for the Canister Storage Building.

\begin{tabular}{|l|c|c|c|c|}
\hline \multirow{2}{*}{$\begin{array}{c}\text { Transport } \\
\text { direction }\end{array}$} & \multicolumn{2}{|c|}{$45^{\circ}$ Sector method } & \multicolumn{2}{c|}{$22.5^{\circ}$ Sector method } \\
\cline { 2 - 5 } & Public access & Site boundary & Public access & Site boundary \\
\hline S & 7,830 & 16,260 & 8,490 & 18,830 \\
\hline SSW & 7,830 & 16,260 & 7,830 & 16,260 \\
\hline WSW & 7,830 & 16,260 & 7,830 & 17,910 \\
\hline W & 7,830 & 17,910 & 9,280 & 18,800 \\
\hline WNW & 9,280 & 18,400 & 10,510 & 18,400 \\
\hline NW & 10,510 & 18,400 & 13,860 & 18,870 \\
\hline NNW & 11,250 & 18,870 & 11,530 & 19,670 \\
\hline N & 11,250 & 19,450 & 11,250 & 19,450 \\
\hline NNE & 11,250 & 19,450 & 12,750 & 22,880 \\
\hline NE & 12,750 & 20,390 & 14,470 & 25,860 \\
\hline ENE & 12,670 & 17,540 & 12,840 & 20,390 \\
\hline E & 12,670 & 17,390 & 12,670 & 17,540 \\
\hline ESE & 12,670 & 17,390 & 14,230 & 17,390 \\
\hline SE & 14,230 & 17,390 & 14,500 & 22,390 \\
\hline SSE & 11,070 & 20,630 & 14,560 & 26,200 \\
\hline
\end{tabular}

"Transport Direction" is from the Canister Storage Building toward the location of interest.

" $45^{\circ}$ Sector Method" uses the shortest distance inside a $45^{\circ}$ sector centered on the direction of interest. This approach is found in NRC Regulatory Guide 1.145, 1982, Atmospheric Dispersion Models for Potential Accident Consequence Assessments at Nuclear Power Plants, U.S. Nuclear Regulatory Commission, Washington, D.C., and is used in further calculations.

"22.5 Sector Method" uses the shortest distance inside a $22.5^{\circ}$ sector centered on the direction of interest. This approach was used in HNF-SD-SNF-TI-059 Rev. 1, and is provided for comparison. 
Table 2-2. Distances (meters) in Each Wind Transport Direction for the Cold Vacuum Drying Facility.

\begin{tabular}{|l|c|c|c|c|}
\hline \multirow{2}{*}{$\begin{array}{c}\text { Transport } \\
\text { direction }\end{array}$} & \multicolumn{2}{|c|}{$45^{\circ}$ Sector method } & \multicolumn{2}{c|}{$22.5^{\circ}$ Sector method } \\
\cline { 2 - 5 } & Public access & Site boundary & Public access & Site boundary \\
\hline S & 12,650 & 24,960 & 15,600 & 24,960 \\
\hline SSW & 11,340 & 17,130 & 12,650 & 25,360 \\
\hline SW & 1,690 & 15,510 & 11,340 & 17,130 \\
\hline WSW & 700 & 11,990 & 1,690 & 15,510 \\
\hline W & 650 & 10,090 & 700 & 11,990 \\
\hline WNW & 580 & 8,740 & 650 & 10,090 \\
\hline NW & 580 & 8,740 & 580 & 8,740 \\
\hline NNW & 580 & 8,740 & 580 & 8,930 \\
\hline N & 580 & 8,930 & 640 & 10,750 \\
\hline NNE & 640 & 10,750 & 860 & 15,390 \\
\hline NE & 860 & 15,390 & 2,540 & 20,080 \\
\hline ENE & 2,540 & 20,080 & 11,470 & 20,510 \\
\hline E & 11,470 & 20,510 & 12,060 & 20,670 \\
\hline ESE & 12,060 & 20,670 & 15,150 & 21,790 \\
\hline SE & 15,150 & 21,790 & 24,290 & 32,320 \\
\hline SSE & 15,600 & 24,960 & 19,660 & 30,830 \\
\hline
\end{tabular}

"Transport Direction" is from the Cold Vacuum Drying Facility toward the location of interest.

" $45^{\circ}$ Sector Method" uses the shortest distance inside a $45^{\circ}$ sector centered on the direction of interest. This approach is found in NRC Regulatory Guide 1.145, 1982, Atmospheric Dispersion Models for Potential Accident Consequence Assessments at Nuclear Power Plants, U.S. Nuclear Regulatory Commission, Washington, D.C., and is used in further calculations.

"22.5 Sector Method" uses the shortest distance inside a $22.5^{\circ}$ sector centered on the direction of interest. This approach was used in HNF-SD-SNF-TI-059 Rev. 1, and is provided for comparison. 
Table 2-3. Distances (meters) in Each Wind Transport Direction for the $100 \mathrm{KW}$ Reactor Building.

\begin{tabular}{|l|c|c|c|c|}
\hline \multirow{2}{*}{$\begin{array}{c}\text { Transport } \\
\text { direction }\end{array}$} & \multicolumn{2}{|c|}{$45^{\circ}$ Sector method } & \multicolumn{2}{c|}{$22.5^{\circ}$ Sector method } \\
\cline { 2 - 5 } & Public access & Site boundary & Public access & Site boundary \\
\hline S & 12,850 & 25,150 & 15,800 & 25,150 \\
\hline SSW & 11,400 & 17,310 & 12,850 & 25,540 \\
\hline WW & 1,060 & 15,660 & 11,400 & 17,310 \\
\hline W & 710 & 12,040 & 1,060 & 15,660 \\
\hline WNW & 520 & 10,070 & 710 & 12,040 \\
\hline NW & 480 & 8,650 & 520 & 10,070 \\
\hline NNW & 480 & 8,650 & 480 & 8,650 \\
\hline N & 480 & 8,650 & 480 & 8,810 \\
\hline NNE & 480 & 8,810 & 530 & 10,910 \\
\hline NE & 530 & 10,910 & 730 & 15,190 \\
\hline ENE & 730 & 15,190 & 2,250 & 19,880 \\
\hline E & 2,250 & 19,880 & 11,330 & 20,380 \\
\hline ESE & 11,330 & 20,380 & 11,780 & 20,570 \\
\hline SE & 11,780 & 20,570 & 15,050 & 21,700 \\
\hline SSE & 15,050 & 21,700 & 24,370 & 32,080 \\
\hline
\end{tabular}

"Transport Direction" is from 100-KW Reactor toward the location of interest.

" $45^{\circ}$ Sector Method" uses the shortest distance inside a $45^{\circ}$ sector centered on the direction of interest. This approach is found in NRC Regulatory Guide 1.145, 1982, Atmospheric Dispersion Models for Potential Accident Consequence Assessments at Nuclear Power Plants, U.S. Nuclear Regulatory Commission, Washington, D.C., and is used in further calculations.

"22.5 Sector Method" uses the shortest distance inside a $22.5^{\circ}$ sector centered on the direction of interest. This approach was used in HNF-SD-SNF-TI-059 Rev. 1, and is provided for comparison. 
Table 2-4. Maximum Individual Locations and Air Transport Factors for Ground-Level Releases.

\begin{tabular}{|c|c|c|c|c|c|}
\hline \multirow{2}{*}{$\begin{array}{l}\text { Receptor } \\
\text { type }\end{array}$} & \multicolumn{5}{|c|}{ Air transport factors, $\mathrm{s} / \mathrm{m}^{3}$} \\
\hline & $<1 \mathrm{hr}$ & $1 \mathrm{hr}$ to $2 \mathrm{hr}$ & $12 \mathrm{hr}^{\mathrm{a}}$ & $24 \mathrm{hr}^{\mathrm{a}}$ & Annual \\
\hline \multicolumn{6}{|c|}{$\mathrm{K}$ West Reactor and adjacent buildings } \\
\hline $\begin{array}{l}\text { Onsite worker } \\
100 \mathrm{~m} \mathrm{E}\end{array}$ & $7.32 \mathrm{E}-02$ & $1.24 \mathrm{E}-02$ & $6.28 \mathrm{E}-03$ & NA & $5.12 \mathrm{E}-04$ \\
\hline $\begin{array}{l}\text { Columbia River } \\
520 \mathrm{~m} \mathrm{~W}\end{array}$ & $3.55 \mathrm{E}-03$ & $6.17 \mathrm{E}-04$ & $2.90 \mathrm{E}-04$ & NA & $1.79 \mathrm{E}-05$ \\
\hline $\begin{array}{l}100 \text { Area Fire Station } \\
3,750 \mathrm{~m} \text { ESE }\end{array}$ & $1.60 \mathrm{E}-04$ & $7.82 \mathrm{E}-05$ & $2.73 \mathrm{E}-05$ & NA & $5.70 \mathrm{E}-07$ \\
\hline $\begin{array}{l}\text { Hanford Site boundary } \\
10,070 \mathrm{~m} \mathrm{~W}\end{array}$ & $4.49 \mathrm{E}-05$ & 3.12 E-05 & $1.01 \mathrm{E}-05$ & $6.51 \mathrm{E}-06$ & $1.58 \mathrm{E}-07$ \\
\hline \multicolumn{6}{|c|}{ Cold Vacuum Drying Facility } \\
\hline $\begin{array}{l}\text { Onsite worker } \\
100 \mathrm{~m} \mathrm{E} \\
\end{array}$ & $7.32 \mathrm{E}-02$ & $1.24 \mathrm{E}-02$ & $6.28 \mathrm{E}-03$ & NA & $5.12 \mathrm{E}-04$ \\
\hline $\begin{array}{l}\text { Columbia River } \\
650 \mathrm{~m} \mathrm{~W} \\
\end{array}$ & $2.44 \mathrm{E}-03$ & $4.25 \mathrm{E}-04$ & $1.99 \mathrm{E}-04$ & NA & $1.21 \mathrm{E}-05$ \\
\hline $\begin{array}{l}100 \text { Area Fire Station } \\
3,750 \mathrm{~m} \text { ESE } \\
\end{array}$ & $1.60 \mathrm{E}-04$ & $7.82 \mathrm{E}-05$ & $2.73 \mathrm{E}-05$ & NA & $5.70 \mathrm{E}-07$ \\
\hline $\begin{array}{l}\text { Hanford Site boundary } \\
10,090 \mathrm{~m} \mathrm{~W}\end{array}$ & $4.48 \mathrm{E}-05$ & $3.11 \mathrm{E}-05$ & $1.01 \mathrm{E}-05$ & $6.50 \mathrm{E}-06$ & $1.58 \mathrm{E}-07$ \\
\hline \multicolumn{6}{|c|}{ Canister Storage Building } \\
\hline $\begin{array}{l}\text { Onsite worker } \\
100 \mathrm{~m} \mathrm{E} \\
\end{array}$ & $3.41 \mathrm{E}-02$ & $1.13 \mathrm{E}-02^{\mathrm{b}}$ & $5.54 \mathrm{E}-03$ & NA & $4.03 \mathrm{E}-04^{\mathrm{b}}$ \\
\hline $\begin{array}{l}\text { Highway } 240 \\
9,280 \mathrm{~m} \mathrm{~W}\end{array}$ & $2.36 \mathrm{E}-05$ & $1.81 \mathrm{E}-05$ & $6.23 \mathrm{E}-06$ & NA & $1.23 \mathrm{E}-07^{\circ}$ \\
\hline $\begin{array}{l}\text { Hanford Site boundary } \\
17,390 \mathrm{~m} \mathrm{E}\end{array}$ & $1.30 \mathrm{E}-05$ & $1.09 \mathrm{E}-05$ & $3.84 \mathrm{E}-06$ & $2.57 \mathrm{E}-06$ & $8.31 \mathrm{E}-08^{\mathrm{d}}$ \\
\hline
\end{tabular}

${ }^{\text {aT }}$ The 12- and 24-hour values are computed by interpolation. The rest are computed by GXQ (WHC-SD-GNSWD-30002, 1993, GXQ Program Users' Guide, Rev. 0, Westinghouse Hanford Company, Richland, Washington). All GXQ runs use a release height and receptor height of zero meters.

${ }^{\mathrm{b}}$ For the Canister Storage Building, this receptor is located $100 \mathrm{~m}$ ESE.

'For the Canister Storage Building, this receptor is located $12,670 \mathrm{~m} \mathrm{E}$.

${ }^{\mathrm{d}}$ For the Canister Storage Building, this receptor is located $17,390 \mathrm{~m}$ ESE.

$\mathrm{NA}=$ not applicable 
Releases lasting 1 hour or more are modeled using plume meander and building wake corrections. No guidance is offered for when these corrections begin to take full effect, so the maximum allowable time ( 1 hour) has been chosen.

Table 2-5 shows the bounding $\chi / Q^{\prime}$ values for onsite and offsite receptors for continuous stack releases under the column heading " $<0.5 \mathrm{hr}$ ". These $\chi / \mathrm{Q}^{\prime}$ values should be used for stack releases less than 0.5 hour in duration. The 0.5 -hour limit comes from NRC Regulatory Guide 1.145 as a general characteristic of fumigation conditions at inland sites. The GXQ software does not model fumigation conditions directly (WHC-SD-GN-SWD-30002). However, the condition can be closely approximated using the MACCS building wake model (NUREG/CR-4691). The input values for building width and height are just the stack diameter and height. The release height should be zero meters (ground level). Finally, the mixing depth should be set equal to the height of the stack.

For the CVDF HVAC stack, the GXQ inputs for building width and height are $0.762 \mathrm{~m}$

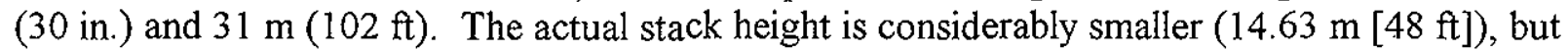
because of the large exhaust flow rate $\left(8.33 \mathrm{~m}^{3} / \mathrm{s}\left[17,650 \mathrm{ft}^{3} / \mathrm{min}\right]\right)$, there is considerable plume rise. Appendix C describes the calculation of plume rise. At low wind speeds $(0.89 \mathrm{~m} / \mathrm{s}$

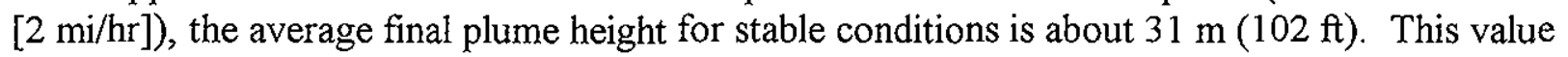
is used for the mixing depth in the GXQ input.

For the CSB HVAC stack, the GXQ inputs for building width and height are $0.71 \mathrm{~m}$

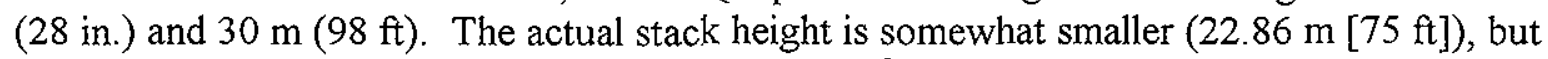
because of the exhaust flow rate $\left(2.12 \mathrm{~m}^{3} / \mathrm{s}\left[4,500 \mathrm{ft}^{3} / \mathrm{min}\right]\right)$, there is significant plume rise. At low wind speed $(0.89 \mathrm{~m} / \mathrm{s}$ [2 mi/hr]), average plume height for stable conditions is $30 \mathrm{~m}(98 \mathrm{ft})$ (Appendix C).

For the CSB's natural circulation stack, the GXQ inputs for building width and height are $2.13 \mathrm{~m}$ and $48 \mathrm{~m}(7 \mathrm{ft}$ and $157 \mathrm{ft})$. The actual stack height is essentially the same $(47.55 \mathrm{~m}$ [156 ft]). As shown in Appendix $\mathrm{C}$, the expected low exhaust flow rates for this stack result in minimal plume rise.

For receptors located farther than $2 \mathrm{~km}$ away, the fumigation model does not apply. The reduced vertical spread of the plume represented by the fumigation model does not hold indefinitely. The long transport time exceeds the duration of the fumigation condition, so other processes affect the dilution and dispersion of the emissions. To model very short release durations at great distances, the " 0.5 to $2 \mathrm{hr}$ " model (discussed below) was simplified by eliminating all adjustments (i.e., building wake, plume meander, and wind speed changes with elevation) and reducing the stack height to half the mixing depth used in the fumigation model. These changes serve to increase the air transport factor to represent very short duration releases while to some degree including the presence of the stack and nearby buildings. 
Table 2-5. Maximum Individual Locations and Air Transport Factors for Stack Releases.

\begin{tabular}{|c|c|c|c|c|c|}
\hline \multirow{2}{*}{$\begin{array}{l}\text { Receptor } \\
\text { type }\end{array}$} & \multicolumn{5}{|c|}{ Air transport factors, $\mathrm{s} / \mathrm{m}^{3}$} \\
\hline & $<0.5 \mathrm{hr}$ & 0.5 to $2 \mathrm{hr}$ & $12 \mathrm{hr}^{\mathrm{a}}$ & $24 \mathrm{hr}^{\mathrm{a}}$ & Annual \\
\hline \multicolumn{6}{|c|}{ Cold Vacuum Drying Facility HVAC stack ( $48 \mathrm{ft}$ ) } \\
\hline Onsite worker & $\begin{array}{l}6.88 \mathrm{E}-03 \\
100 \mathrm{~m} \mathrm{E}\end{array}$ & $\begin{array}{c}6.98 \mathrm{E}-04^{\mathrm{b}} \\
100 \mathrm{~m}\end{array}$ & $3.40 \mathrm{E}-04$ & NA & $\begin{array}{l}2.76 \mathrm{E}-05 \\
150 \mathrm{~m} \mathrm{E}\end{array}$ \\
\hline Columbia River & $\begin{array}{l}9.93 \mathrm{E}-04 \\
650 \mathrm{~m} \mathrm{~W}\end{array}$ & $\begin{array}{c}2.01 \mathrm{E}-04 \\
580 \mathrm{~m} \mathrm{WNW}\end{array}$ & $9.86 \mathrm{E}-05$ & NA & $\begin{array}{l}7.16 \mathrm{E}-06 \\
650 \mathrm{~m} \mathrm{~W}\end{array}$ \\
\hline 100 Area Fire Station & $\begin{array}{c}1.22 \mathrm{E}-04 \\
3,750 \mathrm{ESE}\end{array}$ & $\begin{array}{c}6.61 \mathrm{E}-05 \\
3,750 \mathrm{ESE}\end{array}$ & $2.34 \mathrm{E}-05$ & NA & $\begin{array}{c}5.15 \mathrm{E}-07 \\
3,750 \mathrm{ESE}\end{array}$ \\
\hline Hanford Site boundary & $\begin{array}{c}3.95 \mathrm{E}-05 \\
10,090 \mathrm{~m} \mathrm{~W}\end{array}$ & $\begin{array}{c}2.82 \mathrm{E}-05 \\
10,090 \mathrm{~m} \mathrm{~W}\end{array}$ & $9.18 \mathrm{E}-06$ & $5.95 \mathrm{E}-06$ & $\begin{array}{c}1.48 \mathrm{E}-07 \\
10,090 \mathrm{~m} \mathrm{~W}\end{array}$ \\
\hline \multicolumn{6}{|c|}{ Canister Storage Building HVAC stack (75 ft) } \\
\hline Onsite worker & $\begin{array}{l}4.85 \mathrm{E}-03 \\
100 \mathrm{~m} \mathrm{E}\end{array}$ & $\begin{array}{l}2.66 \mathrm{E}-04 \\
150 \mathrm{~m} \mathrm{~W}\end{array}$ & $1.19 \mathrm{E}-04$ & NA & $\begin{array}{c}6.08 \mathrm{E}-06 \\
100 \mathrm{~m} \mathrm{~S}\end{array}$ \\
\hline Highway 240 & $\begin{array}{l}2.02 \mathrm{E}-05 \\
9,280 \mathrm{~m} \mathrm{~W}\end{array}$ & $\begin{array}{c}1.17 \mathrm{E}-05 \\
9,280 \mathrm{~m} \mathrm{~W}\end{array}$ & 4.09E-06 & NA & $\begin{array}{l}8.60 \mathrm{E}-08 \\
12,670 \mathrm{E}\end{array}$ \\
\hline Hanford Site boundary & $\begin{array}{c}1.25 \mathrm{E}-05 \\
17,390 \mathrm{mE}\end{array}$ & $\begin{array}{c}7.42 \mathrm{E}-06 \\
17,390 \mathrm{~m} \mathrm{E}\end{array}$ & $2.65 \mathrm{E}-06$ & $1.78 \mathrm{E}-06$ & $\begin{array}{c}5.99 \mathrm{E}-08 \\
17,390 \mathrm{~m} \mathrm{ESE}\end{array}$ \\
\hline \multicolumn{6}{|c|}{ Canister Storage Building natural circulation stack (156 ft) } \\
\hline Onsite worker & $\begin{array}{l}3.04 \mathrm{E}-03 \\
100 \mathrm{~m} \mathrm{E}\end{array}$ & $\begin{array}{l}4.84 \mathrm{E}-05 \\
300 \mathrm{~m} \mathrm{~W}\end{array}$ & $2.01 \mathrm{E}-05$ & NA & $\begin{array}{l}7.89 \mathrm{E}-07 \\
250 \mathrm{~m} \mathrm{~S}\end{array}$ \\
\hline Highway 240 & $1.08 \mathrm{E}-05^{\mathrm{b}}$ & $\begin{array}{c}6.66 \mathrm{E}-06 \\
7,830 \mathrm{~m} \mathrm{~S}\end{array}$ & $2.27 \mathrm{E}-06$ & NA & $\begin{array}{l}4.30 \mathrm{E}-08 \\
7,830 \mathrm{~m} \mathrm{~S}\end{array}$ \\
\hline Hanford Site boundary & $\begin{array}{c}\text { 7.23E-06 } \\
17,390 \mathrm{~m} \mathrm{E}\end{array}$ & $\begin{array}{c}3.75 \mathrm{E}-06 \\
17,390 \mathrm{~m} \mathrm{E}\end{array}$ & $1.36 \mathrm{E}-06$ & $9.23 \mathrm{E}-07$ & $\begin{array}{c}\text { 3.31E-08 } \\
\text { 17,390 m ESE }\end{array}$ \\
\hline
\end{tabular}

${ }^{2}$ The 12- and 24-hour values are computed by interpolation. The rest are computed by GXQ

(WHC-SD-GN-SWD-30002, 1993, GXQ Program Users' Guide, Rev. 0, Westinghouse Hanford Company, Richland, Washington). All GXQ runs use a receptor height of $2 \mathrm{~m}$.

${ }^{6}$ These values are the overall site $95 \%$ result. For the Cold Vacuum Drying Facility onsite worker, the sector maximum was $6.73 \mathrm{E}-04 \mathrm{~s} / \mathrm{m}^{3}$ at $100 \mathrm{~m}$ east. For the Canister Storage Building highway receptor, the sector maximum was $1.07 \mathrm{E}-05 \mathrm{~s} / \mathrm{m}^{3}$ at $7,830 \mathrm{~m}$ south.

HVAC $=$ heating, ventilation, and air conditioning.

$\mathrm{NA}=$ not applicable. 
Note that the shortest distance to a boundary did not always lead to the largest air transport. In some cases the wind speed and stability class distributions lead to larger transport factors in other directions than the one with the smallest distance. Values shown in Tables 2-4 and $2-5$ are worst-case numbers. The actual values in each wind transport direction $(9.9 .5 \%)$ as well as the overall site value (95\%) are listed in Appendices A and C.

Tables 2-4 and 2-5 provide the air transport factors for the various facilities associated with the SNF Project (K Basins, CVDF, and CSB). Air transport factors are given for continuous releases only. The $\chi / \mathrm{Q}^{\prime}$ values are given for receptors at onsite work locations, the nearest onsite public access, the 100 Area Fire Station, and the current boundary of the Hanford Site (including the north Wahluke slope). For the $100 \mathrm{~K}$ Area facilities, the nearest onsite public location is the near bank of the Columbia River. For the CSB, the nearest onsite public location is Highway 240.

\subsubsection{Two-Hour Values}

As with the bounding $\chi / \mathrm{Q}^{\prime}$ values, the 2-hour values are computed using the $99.5 \%$ criterion for each sector, and the $95 \%$ criterion for the entire boundary. For each wind transport direction, the $\chi / Q^{\prime}$ values at particular wind speeds and stability classes are computed, sorted, and plotted against the fraction of the hours in a year that they occur. The $99.5 \% \chi / \mathrm{Q}^{\prime}$ values are read from this graph. For the entire boundary, the $\chi / Q^{\prime}$ values at particular wind speeds and stability classes for all 16 directions are computed, sorted, and plotted against the fraction of the hours in a year that they occur. The $95 \% \chi / \mathrm{Q}^{\prime}$ value is read from this graph. The wind transport direction with the largest value is reported on Tables 2-4 and 2-5.

For ground-level releases with durations from 1 to 2 hours, the point-source (i.e., bounding) $\chi / Q^{\prime}$ values are adjusted downward by including the effects of plume meander. NRC Regulatory Guide 1.145 states that 1-hour average $\chi / Q^{\prime}$ values are lower than the bounding model predicts because of plume meander. Thus the plume meander adjustment should be taken if the duration of the release is 1 hour or greater. In reality, some meander effects will be seen at much shorter release durations. Using the unadjusted $\chi / \mathrm{Q}^{\prime}$ values for durations up to 1 hour is certainly conservative. Plume meander is accounted for in the GXQ program (WHC-SD-GN-SWD-30002 and WHC-SD-GN-SWD-30003) using the empirical model given in the in NRC Regulatory Guide 1.145. Table $2-4$ contains $\chi / Q^{\prime}$ values with plume meander for ground-level releases under the column heading " $1 \mathrm{hr}$ to $2 \mathrm{hr}$ ". These $\chi / \mathrm{Q}^{\prime}$ values with plume meander should be used for ground-level releases with durations from 1 to 2 hours.

For stack releases with durations from 0.5 to 2 hours, a typical stack release calculation normally would be done. For the $47.55-\mathrm{m}$ (156-ft) natural circulation stacks at the CSB, this is appropriate because the stack is more than 2.5 times the height of the nearby building. However, for the HVAC stacks at the CSB and CVDF, this is not appropriate because each HVAC stack is just a few feet taller than the roof of the main building nearby. Thus the stack emissions are often captured and diluted in the turbulent eddies near the building. The method used to represent the rooftop emissions from the CVDF and CSB HVAC stacks is the NRC plume meander and building wake model (NRC Regulatory Guide 1.145) with a release height corresponding to the height of the facility. The CVDF is modeled as being $10.67 \mathrm{~m}(35 \mathrm{ft})$ tall and $24.38 \mathrm{~m}(80 \mathrm{ft})$ 
wide. The CSB is modeled as being $18.29 \mathrm{~m}(60 \mathrm{ft})$ tall and $42.37 \mathrm{~m}(139 \mathrm{ft})$ wide. Note that the minimum width of the main structure is used to represent the building.

Using the NRC model (NRC Regulatory Guide 1.145) with an elevated release height results in air transport factors somewhat smaller than those for ground-level emissions. Note that this method approximates the air concentration near stacks that are just above the level of the roof. Normally one would use a split-H model that divides the emission into two parts, one for the stack and one for the building area. Since neither GXQ nor GENII has implemented the split-H model (WHC-SD-GN-SWD-30002, PNL-6584), this approximation scheme is used in its place. Plume rise from momentum effects, stack tip downwash, and wind speed adjustment for elevation are also used in the GXQ input. Table 2-5 contains $\chi / Q^{\prime}$ values for stack releases under the column heading " 0.5 to $2 \mathrm{hr}$." These $\chi / \mathrm{Q}^{\prime}$ values should be used for elevated releases with durations from 0.5 to 2 hours.

\subsubsection{Annual Average Values}

Accident analyses normally do not consider annual release durations. However, the NRC Regulatory Guide 1.145 method for calculating air transport factors for release durations longer than 2 hours requires the use of the annual average $\chi / Q^{\prime}$. Therefore, annual average $\chi / Q^{\prime}$ values are provided for chronic (i.e., routine or long-term) releases.

Annual average $\chi / Q^{\prime}$ values are calculated for each sector, and the sector with the highest annual average $\chi / Q^{\prime}$ value is reported. This is a "sector-averaged" value, which assumes there is no cross-wind variation in concentration within the sector. Annual average $\chi / Q^{\prime}$ values are appropriate for long-term or routine releases not normally associated with accident conditions. The average is computed by weighting the $\chi / Q^{\prime}$ values at individual wind speeds and stability classes by the fraction of the year that those combinations occur in each wind direction. The weighted values are summed to give the annual average. The annual average $\chi / Q^{\prime}$ values included in this report provide a method for calculating $\chi / Q^{\prime}$ values for release durations between 2 hours and 1 year using an interpolation method mentioned in NRC Regulatory Guide 1.145.

Table 2-4 contains annual average $\chi / \mathrm{Q}^{\prime}$ values for ground-level releases from the various SNF Project facilities under the column heading "Annual." The sources are modeled with no adjustments other than the sector-averaging normally used with annual averages. These annual average $\chi / Q^{\prime}$ values should be used for ground-level release durations of 1 year.

Table 2-5 contains annual average $\chi / Q^{\prime}$ values for stack releases from the various SNF Project facilities under the column heading "Annual." The HVAC stacks at the CVDF and CSB are modeled using the roof height as the release height, while the natural circulation stack at the CSB is modeled using the actual stack height. In addition to the sector-averaging normally used with annual averages, plume rise due to momentum effects, stack tip downwash, and the wind speed adjustment for elevated emissions are included in the GXQ input. These annual average $\chi / Q^{\prime}$ values should be used for stack release durations of 1 year. 


\subsubsection{Interpolated Values}

For accident scenarios with release durations from 2 to 8,760 hours ( 1 year), NRC Regulatory Guide 1.145 recommends a logarithmic interpolation method to calculate $\chi / Q^{\prime}$. The interpolation is between the 2 -hour $\chi / Q^{\prime}$ value and the annual average $\chi / Q^{\prime}$ value. Doing the interpolation graphically requires plotting $\chi / \mathrm{Q}^{\prime}$ versus release duration on log-log graph paper and drawing a line between the two points. Analytically, the $\chi / Q^{\prime}$ for release durations between 2 and 8,760 hours is computed using the formula below. The release duration is represented by the symbol " $\mathrm{T}_{\text {rel." }}$ "

$$
\frac{\log \left(\chi / \mathrm{Q}^{\prime}\right)_{\text {rrel }}-\log \left(\chi / \mathrm{Q}^{\prime}\right)_{2 \mathrm{hr}}}{\log \left(\chi / \mathrm{Q}^{\prime}\right)_{\text {chronic }}-\log \left(\chi / \mathrm{Q}^{\prime}\right)_{2 \mathrm{hr}}}=\frac{\log \left(\mathrm{T}_{\text {rel }}\right)-\log (2 \mathrm{hr})}{\log (8,760 \mathrm{hr})-\log (2 \mathrm{hr})}
$$

which can be written more directly as

$$
\begin{gathered}
\left(\chi / \mathrm{Q}^{\prime}\right)_{\text {Trel }}=\left(\chi / \mathrm{Q}^{\prime}\right)_{2 \mathrm{hr}}\left(\frac{\mathrm{T}_{\mathrm{rel}}}{2 \mathrm{hr}}\right)^{\text {slope }} \\
\text { slope }=\frac{\ln \left(\frac{\left(\chi / \mathrm{Q}^{\prime}\right)_{\text {chronic }}}{\left(\chi / \mathrm{Q}^{\prime}\right)_{2 \mathrm{hr}}}\right)}{\ln (8,760 \mathrm{hr} / 2 \mathrm{hr})}
\end{gathered}
$$

This method is illustrated by the following example. Assume an accident at the CVDF is postulated to last 12 hours and produce a ground-level release of some quantity of spent fuel. To calculate the $\chi / \mathrm{Q}^{\prime}$ (12 hours), one first finds the 1-hour to 2 -hour and annual average $\chi / \mathrm{Q}^{\prime}$ values from Table 2-4. For the onsite worker at the $\mathrm{K}$ Basins or CVDF during a ground-level release, the 1-hour to 2-hour $\chi / Q^{\prime}$ is $1.24 \times 10^{-2} \mathrm{~s} / \mathrm{m}^{3}$, and the annual average $\chi / Q^{\prime}$ is $5.12 \times 10^{-4} \mathrm{~s} / \mathrm{m}^{3}$. From the equations above, one finds the result shown below.

$$
\begin{gathered}
\text { slope }=\frac{\ln \left(\frac{5.12 \times 10^{-4} \mathrm{~s} / \mathrm{m}^{3}}{1.24 \times 10^{-2} \mathrm{~s} / \mathrm{m}^{3}}\right)}{\ln (8,760 \mathrm{hr} / 2 \mathrm{hr})}=-0.38011 \\
\left(\chi / \mathrm{Q}^{\prime}\right)_{\text {Trel }}=\left(1.24 \times 10^{-2} \mathrm{~s} / \mathrm{m}^{3}\right)\left(\frac{12 \mathrm{hr}}{2 \mathrm{hr}}\right)^{-0.38011}=6.28 \times 10^{-3} \mathrm{~s} / \mathrm{m}^{3}
\end{gathered}
$$


Interpolated $\chi / Q^{\prime}$ values are given in Tables 2-4 and 2-5 for release durations of 12 hours and 24 hours. Note that the onsite receptors can be exposed for at most 12 hours. This is the longest time a worker is likely to spend in a work location at the Hanford Site. Thus the 24-hour values for onsite receptors are not needed and are not shown on the tables.

\subsubsection{Puff Release Values for Toxicological Releases}

Air concentrations must be computed to evaluate toxicological releases. Long duration emissions are computed using the mass released divided by the release duration and multiplied by the plume air transport factor, $\chi / Q^{\prime}$. Short duration emissions are computed using the mass released multiplied by the puff air transport factor, $\chi / Q$. Plume air transport factors were discussed in previous sections. Puff air transport factors are discussed in this section.

The idealized puff model represents a hemispherical cloud of contamination that is increasing in size as it travels downwind. The air concentration in the center of the puff decreases according to the cube of the distance traveled. The idealized finite plume model represents an oblong shape whose initial length depends on the release duration and wind speed. The finite plume becomes wider and longer as it travels downwind. The air concentration in the center of the finite plume decreases according to the square of the distance traveled. The reason for the difference can be seen by imagining the finite plume as a series of puffs. Adjacent puffs grow as the cube of the distance, but overlap the puffs next to them. In effect, the finite plume is spreading in only two dimensions.

At some point downwind, the finite plume is large enough that it looks and acts like a puff. The concentration in the center begins to fall according to the cube of the distance. The transition from plume to puff depends on the release duration and the stability class. Unstable conditions make the plume spread more quickly with distance, so the transition occurs earlier. When using NRC Regulatory Guide 1.145 methods, there is no defined stability class. Therefore, the next best approach to estimate the transition time is to simply divide the plume air transport factor by the puff air transport factor.

Using the GXQ software, ground-level, point-source $\chi / Q$ values have been computed for each wind speed and stability class and the results sorted and plotted against the fraction of hours in a year that the combination occurs. To be consistent with NRC Regulatory Guide 1.145, the $\chi / Q$ values that are exceeded only $0.5 \%$ of the hours in a year (about 44 hours for all sectors) are shown on Table 2-6 for the worst-case onsite and offsite receptors. Note that puff release values are only given for ground-level emissions. Very short duration (puff) releases from stacks are assumed to be unimportant for SNF Project facilities at the present time. In addition, very short duration releases are hardly affected by building turbulence and elevated release heights. The puff simply follows the building eddies or atmospheric circulation under unstable (i.e., looping) conditions. Buildings and stacks only lower the air concentration when averaged over a period of time. Thus the ground-level puff values can be used to represent stack emissions. 
Table 2-6. Air Transport Factors for Puffs and

Puff-to-Plume Transition Times.

\begin{tabular}{|c|c|c|}
\hline Receptor type & $\begin{array}{l}\text { Air transport factor } \\
\qquad\left(1 / \mathrm{m}^{3}\right)\end{array}$ & $\begin{array}{l}\text { Transition time } \\
\text { (seconds) }\end{array}$ \\
\hline \multicolumn{3}{|c|}{ K West Reactor and adjacent buildings } \\
\hline $\begin{array}{l}\text { Onsite worker } \\
100 \mathrm{~m} \mathrm{E}\end{array}$ & $9.85 \mathrm{E}-03$ & 7.4 \\
\hline $\begin{array}{l}\text { Columbia River } \\
520 \mathrm{~m} \mathrm{~W}\end{array}$ & $1.23 \mathrm{E}-04$ & 29 \\
\hline $\begin{array}{l}100 \text { Area Fire Station } \\
3,750 \mathrm{~m} \mathrm{ESE}\end{array}$ & $8.88 \mathrm{E}-07$ & 180 \\
\hline $\begin{array}{l}\text { Hanford Site boundary } \\
10,070 \mathrm{~m} \mathrm{~W}\end{array}$ & $1.07 \mathrm{E}-07$ & 420 \\
\hline \multicolumn{3}{|c|}{ Cold Vacuum Drying Facility } \\
\hline $\begin{array}{l}\text { Onsite worker } \\
100 \mathrm{~m} \mathrm{E}\end{array}$ & $9.85 \mathrm{E}-03$ & 7.4 \\
\hline $\begin{array}{l}\text { Columbia River } \\
650 \mathrm{~m} \mathrm{~W}\end{array}$ & $6.90 \mathrm{E}-05$ & 35 \\
\hline $\begin{array}{l}100 \text { Area Fire Station } \\
3,750 \mathrm{~m} \mathrm{ESE}\end{array}$ & $8.88 \mathrm{E}-07$ & 180 \\
\hline $\begin{array}{l}\text { Hanford Site boundary } \\
10,090 \mathrm{~m} \mathrm{~W}\end{array}$ & $1.07 \mathrm{E}-07$ & 420 \\
\hline \multicolumn{3}{|c|}{ Canister Storage Building } \\
\hline $\begin{array}{l}\text { Onsite worker } \\
100 \mathrm{~m} \mathrm{ESE}\end{array}$ & $9.85 \mathrm{E}-03$ & 3.5 \\
\hline $\begin{array}{l}\text { Highway } 240 \\
11,070 \mathrm{~m} \mathrm{SE}\end{array}$ & 8.04 E-08 & 260 \\
\hline $\begin{array}{l}\text { Hanford Site boundary } \\
17,390 \mathrm{~m} \mathrm{E}\end{array}$ & $3.58 \mathrm{E}-08$ & 360 \\
\hline
\end{tabular}

Note that the larger of the release duration or the exposure averaging time should be compared with the above transition times. Releases lasting less than the transition time should be treated as puffs, longer durations as plumes. 
Time limits on release durations are given in Table 2-6. The time values are computed by dividing the puff $\chi / \mathrm{Q}$ into the bounding (point source) plume $\chi / \mathrm{Q}^{\prime}$ from Table 2-4. Note that the greater the receptor distance, the longer the release can last and still be treated as a puff at the receptor location. These maximum release durations are called transition times. For a given accident scenario, the estimated release duration must be compared with the transition time to decide whether to use a puff or plume air transport factor. Release durations less than the transition time should be modeled as puffs. Release durations greater than the transition time should be modeled as plumes. It is overly conservative to use the puff model for longer times or the continuous release model for shorter times. 
HNF-SD-SNF-TI-059 REV 2

This page intentionally left blank. 


\subsection{RADIOLOGICAL CONSEQUENCE METHODOLOGY}

\subsection{SOURCE COMPOSITION AND UNIT DOSE}

The radionuclide composition of SNF for safety analysis modeling was obtained from information contained in HNF-SD-SNF-TI-015, Spent Nuclear Fuel Project Technical Databook. The safety-basis values were selected based on potential inhalation dose from the mixture. The worst-case radioisotope mixture is Mark IV fuel irradiated to $16.72 \%{ }^{240} \mathrm{Pu}$ content and discharged on February 20, 1979. These radioisotopes are then decayed to May 31, 1998. The long decay half-lives of the main contributors (plutonium and americium) means the decay time has little effect on the resulting doses. Table 3-1 shows this radionuclide composition in both $\mathrm{Ci} / \mathrm{MTU}$ and $\mathrm{Bq} / \mathrm{g} \mathrm{U}$.

Assuming that this mixture becomes airborne as respirable-sized particles, a unit dose factor that gives the dose per gram inhaled can be computed. It is assumed that the relative amounts of each radionuclide do not change. The usefulness of this dose factor is that one number replaces many numbers (i.e., the individual dose factors for each nuclide). The drawback to this number is that it only applies to one specific nuclide composition.

The unit dose factor is the sum of the products of the activity per gram of uranium and the effective dose equivalent (EDE) per unit activity inhaled as shown in the equation below. These dose factors are compiled in various references and can be computed by the GENII software (PNL-6584). For this report, values for "Inhalation dose factor" were taken from Federal Guidance Report Number 11, Limiting Values of Radionuclide Intake and Air Concentration and Dose Conversion Factors for Inhalation, and are listed on Table 3-1. The computed unit dose factors are listed in the column labeled "Unit dose." To indicate the relative importance of the various radionuclides to the total dose, the last column shows the fraction contributed by each nuclide to the total dose per gram inhaled.

$$
\mathrm{UD}=\sum_{\mathrm{K}}(\mathrm{UQK})(\mathrm{DFK})
$$

where

$$
\begin{aligned}
\mathrm{UD}= & 50 \text {-year committed } \mathrm{EDE} \text { from inhalation of a unit mass of SNF as respirable } \\
& \text { particles, } \mathrm{Sv} / \mathrm{g} \\
\mathrm{UQ}_{\mathrm{K}}= & \text { activity of the Kth nuclide per unit mass of } \mathrm{SNF}, \mathrm{Bq} / \mathrm{g} \\
\mathrm{DF}_{\mathrm{K}}= & 50 \text {-year committed EDE per unit activity inhaled of the Kth nuclide, } \mathrm{Sv} / \mathrm{Bq} .
\end{aligned}
$$


Table 3-1. Radionuclide Composition of Fuel and the Unit Dose Factor. (3 sheets)

\begin{tabular}{|c|c|c|c|c|c|c|}
\hline \multirow{2}{*}{ Nuclide } & \multirow{2}{*}{$\begin{array}{c}\text { Activity }^{\mathrm{a}} \\
\text { (Ci/MTU) }\end{array}$} & \multirow{2}{*}{$\begin{array}{l}\text { Activity } \\
(\mathrm{Bq} / \mathrm{g} U)\end{array}$} & \multicolumn{2}{|c|}{ Inhalation dose factor ${ }^{b}$} & \multirow{2}{*}{$\begin{array}{l}\text { Unit dose }^{c} \\
(\mathrm{~Sv} / \mathrm{g} \mathrm{U})\end{array}$} & \multirow{2}{*}{$\begin{array}{c}\text { Percent } \\
\text { of } \\
\text { total }\end{array}$} \\
\hline & & & $(\mathrm{Sv} / \mathrm{Bq})$ & Class & & \\
\hline \multicolumn{7}{|c|}{ Fission and activation products } \\
\hline $\mathrm{H}-3$ & $2.61 \mathrm{E}+01$ & $9.66 \mathrm{E}+05$ & $2.60 \mathrm{E}-11$ & Vapor & $2.51 \mathrm{E}-05$ & $0.00 \%$ \\
\hline C-14 & $5.53 \mathrm{E}-01$ & $2.05 \mathrm{E}+04$ & $5.64 \mathrm{E}-10$ & Organic & $1.15 \mathrm{E}-05$ & $0.00 \%$ \\
\hline Fe-55 & $5.41 \mathrm{E}-01$ & $2.00 \mathrm{E}+04$ & $7.26 \mathrm{E}-10$ & $\mathrm{D}$ & $1.45 \mathrm{E}-05$ & $0.00 \%$ \\
\hline Co-60 & $2.09 \mathrm{E}+00$ & $7.73 \mathrm{E}+04$ & $5.91 \mathrm{E}-08$ & $\mathrm{Y}$ & $4.57 \mathrm{E}-03$ & $0.00 \%$ \\
\hline $\mathrm{Ni}-59$ & $3.18 \mathrm{E}-02$ & $1.18 \mathrm{E}+03$ & $7.31 \mathrm{E}-10$ & Vapor & $8.60 \mathrm{E}-07$ & $0.00 \%$ \\
\hline $\mathrm{Ni}-63$ & $3.47 \mathrm{E}+00$ & $1.28 \mathrm{E}+05$ & 1.70 E-09 & Vapor & $2.18 \mathrm{E}-04$ & $0.00 \%$ \\
\hline $\mathrm{Se}-79$ & $6.54 \mathrm{E}-02$ & $2.42 \mathrm{E}+03$ & $2.66 \mathrm{E}-09$ & W & 6.44 E-06 & $0.00 \%$ \\
\hline $\mathrm{Kr}-85$ & $3.70 \mathrm{E}+02$ & $1.37 \mathrm{E}+07$ & $3.57 \mathrm{E}-13$ & $\operatorname{Gas}^{d}$ & $4.89 \mathrm{E}-06$ & $0.00 \%$ \\
\hline $\mathrm{Sr}-90$ & $6.93 \mathrm{E}+03$ & $2.56 \mathrm{E}+08$ & $6.47 \mathrm{E}-08$ & $\mathrm{D}$ & $1.66 \mathrm{E}+01$ & $0.38 \%$ \\
\hline$Y-90$ & $6.93 \mathrm{E}+03$ & $2.56 \mathrm{E}+08$ & $2.28 \mathrm{E}-09$ & $\mathrm{Y}$ & $5.85 \mathrm{E}-01$ & $0.01 \%$ \\
\hline $\mathrm{Zr}-93$ & $2.95 \mathrm{E}-01$ & $1.09 \mathrm{E}+04$ & $8.67 \mathrm{E}-08$ & $\mathrm{D}$ & $9.46 \mathrm{E}-04$ & $0.00 \%$ \\
\hline $\mathrm{Nb}-93 \mathrm{~m}$ & $1.93 \mathrm{E}-01$ & $7.14 E+03$ & 7.90 E-09 & $\mathrm{Y}$ & 5.64 E-05 & $0.00 \%$ \\
\hline Tc-99 & $2.19 \mathrm{E}+00$ & $8.10 \mathrm{E}+04$ & $2.25 \mathrm{E}-09$ & $W$ & $1.82 \mathrm{E}-04$ & $0.00 \%$ \\
\hline Ru-1.06 & $2.56 \mathrm{E}-02$ & $9.47 \mathrm{E}+02$ & $1.29 \mathrm{E}-07$ & $\mathrm{Y}$ & 1.22 E-04 & $0.00 \%$ \\
\hline Rh-106 & $2.56 \mathrm{E}-02$ & $9.47 \mathrm{E}+02$ & $\mathrm{DP}^{\mathrm{e}}$ & $\mathrm{NA}$ & NA & NA \\
\hline $\mathrm{Pd}-107$ & $1.56 \mathrm{E}-02$ & $5.77 \mathrm{E}+02$ & $3.45 \mathrm{E}-09$ & $\mathrm{Y}$ & $1.99 \mathrm{E}-06$ & $0.00 \%$ \\
\hline $\mathrm{Ag}-110$ & $7.17 \mathrm{E}-10$ & $2.65 \mathrm{E}-05$ & $\mathrm{DP}^{\mathrm{e}}$ & NA & $\mathrm{NA}$ & $\mathrm{NA}$ \\
\hline $\mathrm{Ag}-110 \mathrm{~m}$ & $5.39 \mathrm{E}-08$ & $1.99 \mathrm{E}-03$ & $2.17 \mathrm{E}-08$ & $\mathrm{Y}$ & 4.33 E-11 & $0.00 \%$ \\
\hline $\mathrm{Cd}-113 \mathrm{~m}$ & $2.78 \mathrm{E}+00$ & $1.03 \mathrm{E}+05$ & $4.13 \mathrm{E}-07$ & $\mathrm{D}$ & $4.25 \mathrm{E}-02$ & $0.00 \%$ \\
\hline In- $113 \mathrm{~m}$ & $1.36 \mathrm{E}-19$ & $5.03 \mathrm{E}-15$ & $1.11 \mathrm{E}-11$ & $\mathrm{D}$ & $5.59 \mathrm{E}-26$ & $0.00 \%$ \\
\hline Sn-113 & $1.36 \mathrm{E}-19$ & $5.03 \mathrm{E}-15$ & $2.88 \mathrm{E}-09$ & W & $1.45 \mathrm{E}-23$ & $0.00 \%$ \\
\hline $\mathrm{Sn}-119 \mathrm{~m}$ & $6.14 \mathrm{E}-08$ & $2.27 \mathrm{E}-03$ & $1.69 \mathrm{E}-09$ & W & 3.84 E-12 & $0.00 \%$ \\
\hline Sn-12lm & $6.27 \mathrm{E}-02$ & $2.32 \mathrm{E}+03$ & 3.22 E-09 & W & $7.46 \mathrm{E}-06$ & $0.00 \%$ \\
\hline Sn-123 & $1.72 \mathrm{E}-16$ & $6.36 \mathrm{E}-12$ & 8.79 E-09 & W & $5.59 \mathrm{E}-20$ & $0.00 \%$ \\
\hline Sn-126 & $1.29 \mathrm{E}-01$ & $4.77 \mathrm{E}+03$ & $2.69 \mathrm{E}-08$ & W & $1.28 \mathrm{E}-04$ & $0.00 \%$ \\
\hline $\mathrm{Sb}-125$ & $0.00 \mathrm{E}+00$ & $0.00 \mathrm{E}+00$ & 3.30 E-09 & $W$ & $0.00 \mathrm{E}+00$ & $0.00 \%$ \\
\hline
\end{tabular}


Table 3-1. Radionuclide Composition of Fuel and the Unit Dose Factor. (3 sheets)

\begin{tabular}{|c|c|c|c|c|c|c|}
\hline \multirow{2}{*}{ Nuclide } & \multirow{2}{*}{$\begin{array}{l}\text { Activity }^{\mathrm{a}} \\
\text { (Ci/MTU) }\end{array}$} & \multirow{2}{*}{$\begin{array}{l}\text { Activity } \\
(\mathrm{Bq} / \mathrm{g} \mathrm{U})\end{array}$} & \multicolumn{2}{|c|}{ Inhalation dose factor ${ }^{b}$} & \multirow{2}{*}{$\begin{array}{l}\text { Unit dose }^{c} \\
(\mathrm{~Sv} / \mathrm{g} \mathrm{U})\end{array}$} & \multirow{2}{*}{$\begin{array}{c}\text { Percent } \\
\text { of } \\
\text { total }\end{array}$} \\
\hline & & & $(\mathrm{Sv} / \mathrm{Bq})$ & Class & & \\
\hline $\mathrm{Sb}-126$ & $1.81 \mathrm{E}-02$ & $6.70 \mathrm{E}+02$ & 3.17 E-09 & $W$ & $2.12 \mathrm{E}-06$ & $0.00 \%$ \\
\hline $\mathrm{Sb}-126 \mathrm{~m}$ & $1.29 \mathrm{E}-01$ & $4.77 \mathrm{E}+03$ & $9.17 \mathrm{E}-12$ & $\mathrm{D}$ & $4.38 \mathrm{E}-08$ & $0.00 \%$ \\
\hline $\mathrm{Te}-123 \mathrm{~m}$ & $1.50 \mathrm{E}-21$ & $5.55 \mathrm{E}-17$ & $2.86 \mathrm{E}-09$ & $\mathrm{D}$ & $1.59 \mathrm{E}-25$ & $0.00 \%$ \\
\hline $\mathrm{Te}-125 \mathrm{~m}$ & $0.00 \mathrm{E}+00$ & $0.00 \mathrm{E}+00$ & $1.97 \mathrm{E}-09$ & $\mathrm{~W}$ & $0.00 \mathrm{E}+00$ & $0.00 \%$ \\
\hline $\mathrm{Te}-127$ & $2.12 \mathrm{E}-19$ & $7.84 \mathrm{E}-15$ & $8.60 \mathrm{E}-11$ & W & $6.75 \mathrm{E}-25$ & $0.00 \%$ \\
\hline $\mathrm{Te}-127 \mathrm{~m}$ & $2.16 \mathrm{E}-19$ & 7.99 E-15 & $5.81 \mathrm{E}-09$ & W & $4.64 \mathrm{E}-23$ & $0.00 \%$ \\
\hline $\mathrm{I}-129$ & $5.16 \mathrm{E}-03$ & $1.91 \mathrm{E}+02$ & $4.69 \mathrm{E}-08$ & $\mathrm{D}$ & 8.95 E-06 & $0.00 \%$ \\
\hline $\mathrm{Cs}-134$ & $6.47 \mathrm{E}+00$ & $2.39 \mathrm{E}+05$ & $1.25 \mathrm{E}-08$ & $\mathrm{D}$ & $2.99 \mathrm{E}-03$ & $0.00 \%$ \\
\hline $\mathrm{Cs}-135$ & $6.04 \mathrm{E}-02$ & $2.23 \mathrm{E}+03$ & $1.23 \mathrm{E}-09$ & $\mathrm{D}$ & $2.75 \mathrm{E}-06$ & $0.00 \%$ \\
\hline $\mathrm{Cs}-137$. & $9.66 \mathrm{E}+03$ & $3.57 E+08$ & 8.63 E-09 & $\mathrm{D}$ & $3.08 \mathrm{E}+00$ & $0.07 \%$ \\
\hline $\mathrm{Ba}-137 \mathrm{~m}$ & $9.14 \mathrm{E}+03$ & $3.38 \mathrm{E}+08$ & $\mathrm{DP}^{\mathrm{e}}$ & $\mathrm{NA}$ & NA & $\mathrm{NA}$ \\
\hline $\mathrm{Ce}-144$ & $7.91 \mathrm{E}-04$ & $2.93 \mathrm{E}+01$ & $1.01 \mathrm{E}-07$ & $\mathrm{Y}$ & 2.96 E-06 & $0.00 \%$ \\
\hline Pr-144 & $7.82 \mathrm{E}-04$ & $2.89 \mathrm{E}+01$ & $1.17 \mathrm{E}-11$ & $\mathrm{Y}$ & $3.39 \mathrm{E}-10$ & $0.00 \%$ \\
\hline $\operatorname{Pr}-144 \mathrm{~m}$ & $9.48 \mathrm{E}-06$ & $3.51 \mathrm{E}-01$ & $\mathrm{DP}^{e}$ & $\mathrm{NA}$ & NA & NA \\
\hline $\mathrm{Pm}-147$ & $1.09 \mathrm{E}+02$ & $4.03 \mathrm{E}+06$ & $1.06 \mathrm{E}-08$ & $\mathrm{Y}$ & $4.28 \mathrm{E}-02$ & $0.00 \%$ \\
\hline $\mathrm{Sm}-151$ & $1.02 \mathrm{E}+02$ & $3.77 \mathrm{E}+06$ & $8.10 \mathrm{E}-09$ & W & $3.06 \mathrm{E}-02$ & $0.00 \%$ \\
\hline Eu-152 & 8.45 E-01 & $3.13 \mathrm{E}+04$ & 5.97 E-08 & $\mathrm{W}$ & $1.87 \mathrm{E}-03$ & $0.00 \%$ \\
\hline Eu-154 & $1.13 E+02$ & $4.18 \mathrm{E}+06$ & 7.73 E-08 & $\mathrm{W}$ & $3.23 \mathrm{E}-01$ & $0.01 \%$ \\
\hline Eu-155 & $1.06 E+01$ & $3.92 \mathrm{E}+05$ & $1.12 \mathrm{E}-08$ & $W$ & $4.39 \mathrm{E}-03$ & $0.00 \%$ \\
\hline Gd-153 & $5.19 \mathrm{E}-19$ & $1.92 \mathrm{E}-14$ & $6.43 \mathrm{E}-09$ & $\mathrm{D}$ & $1.23 \mathrm{E}-22$ & $0.00 \%$ \\
\hline Subtotal: & $3.34 \mathrm{E}+04$ & $1.24 \mathrm{E}+09$ & $1.20 \mathrm{E}-06$ & & $2.07 \mathrm{E}+01$ & $0.47 \%$ \\
\hline \multicolumn{7}{|c|}{ Actinides } \\
\hline U-234 & 3.84 E-01 & $1.42 \mathrm{E}+04$ & $3.58 \mathrm{E}-05$ & $Y$ & 5.09 E-01 & $0.01 \%$ \\
\hline $\mathrm{U}-235$ & $1.27 \mathrm{E}-02$ & $4.70 \mathrm{E}+02$ & 3.32 E-05 & $Y$ & $1.56 \mathrm{E}-02$ & $0.00 \%$ \\
\hline $\mathrm{U}-236$ & $7.16 \mathrm{E}-02$ & $2.65 \mathrm{E}+03$ & $3.39 \mathrm{E}-05$ & $\mathrm{Y}$ & $8.98 \mathrm{E}-02$ & $0.00 \%$ \\
\hline U-238 & $3.31 \mathrm{E}-01$ & $1.22 \mathrm{E}+04$ & $3.20 \mathrm{E}-05$ & $\mathrm{Y}$ & $3.92 \mathrm{E}-01$ & $0.01 \%$ \\
\hline $\mathrm{Np}-237$ & $4.66 \mathrm{E}-02$ & $1.72 E+03$ & $1.46 \mathrm{E}-04$ & $\mathrm{~W}$ & $2.52 \mathrm{E}-01$ & $0.01 \%$ \\
\hline
\end{tabular}


Table 3-1. Radionuclide Composition of Fuel and the Unit Dose Factor. (3 sheets)

\begin{tabular}{|c|c|c|c|c|c|c|}
\hline \multirow{2}{*}{ Nuclide } & \multirow{2}{*}{$\begin{array}{l}\text { Activity }^{\mathrm{a}} \\
\text { (Ci/MTU) }\end{array}$} & \multirow{2}{*}{$\begin{array}{l}\text { Activity } \\
(\mathrm{Bq} / \mathrm{g} U)\end{array}$} & \multicolumn{2}{|c|}{ Inhalation dose factor ${ }^{b}$} & \multirow{2}{*}{$\begin{array}{l}\text { Unit dose }^{\mathrm{c}} \\
(\mathrm{Sv} / \mathrm{g} \mathrm{U})\end{array}$} & \multirow{2}{*}{$\begin{array}{c}\text { Percent } \\
\text { of } \\
\text { total }\end{array}$} \\
\hline & & & $(\mathrm{Sv} / \mathrm{Bq})^{\circ}$ & Class & & \\
\hline $\mathrm{Pu}-238$ & $1.33 \mathrm{E}+02$ & $4.92 \mathrm{E}+06$ & $1.06 \mathrm{E}-04$ & $W$ & $5.22 \mathrm{E}+02$ & $11.91 \%$ \\
\hline Pu-239 & $1.73 E+02$ & $6.40 \mathrm{E}+06$ & $1.16 \mathrm{E}-04$ & $W$ & $7.43 \mathrm{E}+02$ & $16.96 \%$ \\
\hline $\mathrm{Pu}-240$ & $1.37 \mathrm{E}+02$ & $5.07 \mathrm{E}+06$ & $1.16 \mathrm{E}-04$ & $\mathrm{~W}$ & $5.88 \mathrm{E}+02$ & $13.43 \%$ \\
\hline $\mathrm{Pu}-241$ & $6.82 \mathrm{E}+03$ & $2.52 \mathrm{E}+08$ & $2.23 \mathrm{E}-06$ & W & $5.63 E+02$ & $12.85 \%$ \\
\hline $\mathrm{Pu}-242$ & $8.71 \mathrm{E}-02$ & $3.22 \mathrm{E}+03$ & $1.11 \mathrm{E}-04$ & W & $3.58 \mathrm{E}-01$ & $0.01 \%$ \\
\hline Am-241 & $4.34 \mathrm{E}+02$ & $1.61 \mathrm{E}+07$ & $1.20 \mathrm{E}-04$ & W & $1.93 \mathrm{E}+03$ & $44.01 \%$ \\
\hline $\mathrm{Am}-242$ & $3.71 \mathrm{E}-01$ & $1.37 \mathrm{E}+04$ & $1.58 \mathrm{E}-08$ & W & 2.17 E-04 & $0.00 \%$ \\
\hline $\mathrm{Am}-242 \mathrm{~m}$ & $3.72 \mathrm{E}-01$ & $1.38 \mathrm{E}+04$ & $1.15 \mathrm{E}-04$ & $\mathrm{~W}$ & $1.58 \mathrm{E}+00$ & $0.04 \%$ \\
\hline Am-243 & $2.78 \mathrm{E}-01$ & $1.03 \mathrm{E}+04$ & $1.19 \mathrm{E}-04$ & W & $1.22 \mathrm{E}+00$ & $0.03 \%$ \\
\hline $\mathrm{Cm}-242$ & $3.08 \mathrm{E}-01$ & $1.14 \mathrm{E}+04$ & $4.67 \mathrm{E}-06$ & $\mathrm{~W}$ & $5.32 \mathrm{E}-02$ & $0.00 \%$ \\
\hline $\mathrm{Cm}-244$ & $4.47 E+00$ & $1.65 \mathrm{E}+05$ & 6.70 E-05 & W & $1.11 \mathrm{E}+01$ & $0.25 \%$ \\
\hline Subtotal: & $7.70 \mathrm{E}+03$ & $2.85 \mathrm{E}+08$ & $1.16 \mathrm{E}-03$ & & $4.36 \mathrm{E}+03$ & $99.53 \%$ \\
\hline & & & & & $4.38 \mathrm{E}+03$ & $\mathrm{~Sv} / \mathrm{g} \mathrm{U}$ \\
\hline
\end{tabular}

${ }^{2}$ Results are decayed to May 31, 1998. Fuel activities are from HNF-SD-SNF-TI-015, 1998, Spent Nuclear Fuel Project Technical Databook, Rev. 6, Fluor Daniel Hanford, Incorporated, Richland, Washington.

'Inhalation dose factors are bounding values from Federal Guidance Report Number 11, 1988, Limiting Values of Radionuclide Intake and Air Concentration and Dose Conversion Factors for Inhalation, Submersion, and Ingestion, U.S. Environmental Protection Agency, Washington, D.C. The internal dose factor for tritium was increased by $50 \%$ to include absorption through the skin.

The unit dose is the product of the normalized activity and the inhalation dose factor. To convert Sv/g to rem/g multiply by 100 .

${ }^{d}$ Krypton- 85 is a noble gas. It does not accumulate in the body; therefore its internal dose factor is zero. The value shown is the external dose rate factor for submersion in an infinite cloud divided by the light activity breathing rate.

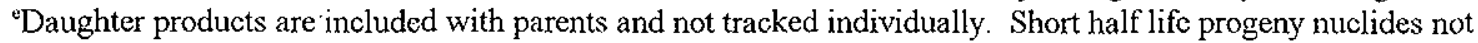
shown are assumed to be in equilibrium with their parent nuclide.

$\mathrm{D}=$ very soluble compounds with lung residence times of days

$\mathrm{DP}=$ daughter product.

MTU $=$ metric ton of uranium.

$\mathrm{NA}=$ not applicable.

$\mathrm{W}=$ moderately soluble compounds with lung residence times of weeks

$\mathrm{Y}=$ insoluble compounds with lung residence times of years 
For nuclides with more than one biological lung clearance class, the class that gives the largest dose factor is used unless clear justification for non-conservative values can be provided. These represent bounding values. More realistic lung clearance classes based on insoluble chemical forms have been selected to evaluate the degree of conservatism built into the unit dose. These are shown in Appendix $\mathrm{F}$ together with a summary table with all unit dose factors. The more realistic value for unit dose is $17 \%$ lower than the value recommended above for use in the SNF accident calculations.

The unit dose in consequence analysis for accident scenarios for the SNF Project is $4.38 \times 10^{3} \mathrm{~Sv} / \mathrm{g}\left(4.38 \times 10^{5} \mathrm{rem} / \mathrm{g}\right)$. As can be seen from the table, the radionuclides that account for $99.5 \%$ of the unit dose are ${ }^{238} \mathrm{Pu},{ }^{239} \mathrm{Pu},{ }^{240} \mathrm{Pu},{ }^{241} \mathrm{Pu},{ }^{241} \mathrm{Am}$, and ${ }^{244} \mathrm{Cm}$. Fuel that has been processed to remove transuranic isotopes would have a substantially lower unit dose. Note that the unit dose value presented here assumes the full mixture of spent fuel is present in the airborne material. In other words, all nuclides have the same release fraction. Accident scenarios that preferentially release certain nuclides may require calculation of a new unit dose.

Inhalation of SNF particles also produces doses to individual organs. The NRC has established dose equivalent limits (10 CFR 72.106) for organs as well as the risk-based EDE. The NRC recently revised the dose equivalent limits for individuals at the nearest boundary from design basis accidents (DBA) to be consistent with ICRP Publication 26, Recommendations of the International Commission on Radiological Protection. The new EDE limit is $5 \mathrm{rem}$, and the corresponding organ dose limit is 50 rem.

For comparison with the NRC DBA limits, organ doses from inhalation of SNF were computed using the same methods as for the EDE. Since the various nuclides in SNF have different target organs, several organs were used in the calculation and the organ with the greatest dose was selected. The inhalation dose factors for five organs are shown in Table 3-2, along with the external dose rate factors for submersion in a semi-infinite cloud for a person standing on the ground. Both of these dose factors are from recent U.S. Environmental Protection Agency compilations (Federal Guidance Report No. 11, Federal Guidance Report No. 12). Table 3-3 shows the resulting unit dose factors. Organs not listed in the table were found to have smaller unit dose factors. The organ unit dose factors were computed as the product of the organ dose factor from Table 3-2 and the activity concentration in the fuel from Table 3-1. The external unit dose factors were computed as the external dose rate factor from Table 3-2 divided by the light activity breathing rate $\left(3.33 \mathrm{E}-04 \mathrm{~m}^{3} / \mathrm{s}\right)$ and multiplied by the SNF activity concentration from Table 3-1.

The organ with the largest unit dose is the bone surface. Note that the organ unit dose is a factor of 18 larger than the EDE unit dose shown on Table 3-1. For anticipated events, the offsite dose guideline is $0.5 \mathrm{rem}$ (Table 1-1). An accident with an offsite dose of $0.5 \mathrm{rem}$ also produces an organ dose of 9 rem (to the bone surface). These doses are less than the NRC limits. Therefore, accidents with offsite doses below the DOE-RL guidance for anticipated events will necessarily be in compliance with the NRC limits. 
Table 3-2. Organ Dose Factors from Inhalation and Air Submersion Dose Factors. (3 sheets)

\begin{tabular}{|c|c|c|c|c|c|c|}
\hline \multirow{2}{*}{ Nuclide } & \multicolumn{5}{|c|}{ Inhalation dose factors, $\mathrm{Sv} / \mathrm{Bq}^{\mathrm{a}}$} & \multirow{2}{*}{$\begin{array}{c}\text { Air } \\
\text { submersion } \\
(\mathrm{Sv} / \mathrm{s} \text { per } \\
\left.\mathrm{Bq} / \mathrm{m}^{3}\right)\end{array}$} \\
\hline & Bone surface & Red marrow & Lungs & Gonads & Remainder & \\
\hline \multicolumn{7}{|c|}{ Fission and activation products } \\
\hline $\mathrm{H}-3$ & $2.60 \mathrm{E}-11$ & $2.60 \mathrm{E}-11$ & $2.60 \mathrm{E}-11$ & $2.60 \mathrm{E}-11$ & $2.60 \mathrm{E}-11$ & $3.31 \mathrm{E}-19$ \\
\hline C-14 & $5.64 \mathrm{E}-10$ & $5.64 \mathrm{E}-10$ & $5.64 \mathrm{E}-10$ & $5.64 \mathrm{E}-10$ & $5.64 \mathrm{E}-10$ & $2.24 \mathrm{E}-19$ \\
\hline $\mathrm{Fe}-55$ & $5.14 \mathrm{E}-10$ & $5.17 \mathrm{E}-10$ & $5.19 \mathrm{E}-10$ & $5.23 \mathrm{E}-10$ & $1.21 \mathrm{E}-09$ & 0.0 \\
\hline $\mathrm{Co}-60$ & $1.35 \mathrm{E}-08$ & $1.72 \mathrm{E}-08$ & $3.45 \mathrm{E}-07$ & $4.76 \mathrm{E}-09$ & $3.60 \mathrm{E}-08$ & $1.26 \mathrm{E}-13$ \\
\hline $\mathrm{Ni}-59$ & $7.25 \mathrm{E}-10$ & $7.31 \mathrm{E}-10$ & $7.14 \mathrm{E}-10$ & 7.43 E-10 & $7.33 \mathrm{E}-10$ & 0.0 \\
\hline $\mathrm{Ni}-63$ & $1.70 \mathrm{E}-09$ & 1.70 E-09 & $1.73 \mathrm{E}-09$ & $1.70 \mathrm{E}-09$ & $1.70 \mathrm{E}-09$ & 0.0 \\
\hline $\mathrm{Se}-79$ & $5.98 \mathrm{E}-10$ & $5.98 \mathrm{E}-10$ & $9.81 \mathrm{E}-09$ & $5.98 \mathrm{E}-10$ & 3.77 E-09 & 3.03 E-19 \\
\hline $\mathrm{Kr}-85$ & 0.0 & 0.0 & 0.0 & 0.0 & 0.0 & $1.19 \mathrm{E}-16$ \\
\hline $\operatorname{Sr}-90$ & $7.27 \mathrm{E}-07$ & $3.36 \mathrm{E}-07$ & 3.73 E-09 & 2.64 E-09 & 3.36 E-09 & $7.53 \mathrm{E}-18$ \\
\hline$Y-90$ & $1.51 \mathrm{E}-11$ & $1.52 \mathrm{E}-11$ & $9.31 \mathrm{E}-09$ & $5.17 \mathrm{E}-13$ & $3.87 \mathrm{E}-09$ & $1.90 \mathrm{E}-16$ \\
\hline Zr-93 & $2.18 \mathrm{E}-06$ & $1.77 \mathrm{E}-07$ & $8.68 \mathrm{E}-11$ & $2.18 \mathrm{E}-11$ & $8.48 \mathrm{E}-11$ & 0.0 \\
\hline $\mathrm{Nb}-93 \mathrm{~m}$ & $2.84 \mathrm{E}-10$ & $1.14 \mathrm{E}-10$ & $6.45 \mathrm{E}-08$ & $1.55 \mathrm{E}-10$ & 3.04 E-10 & $4.44 \mathrm{E}-18$ \\
\hline Tc-99 & 3.99 E-11 & $3.99 \mathrm{E}-1 \mathrm{I}$ & $1.67 \mathrm{E}-08$ & 3.99 E-11 & $6.26 \mathrm{E}-10$ & $1.62 \mathrm{E}-18$ \\
\hline Ru-106 & $1.61 \mathrm{E}-09$ & $1.76 \mathrm{E}-09$ & $1.04 \mathrm{E}-06$ & $1.30 \mathrm{E}-09$ & $1.20 \mathrm{E}-08$ & 0.0 \\
\hline $\mathrm{Rh}-106$ & $0.0^{b}$ & $0.0^{\mathrm{b}}$ & $0.0^{\mathrm{b}}$ & $0.0^{\mathrm{b}}$ & $0.0^{\mathrm{b}}$ & $1.04 \mathrm{E}-14$ \\
\hline Pd-107 & $1.51 \mathrm{E}-12$ & $5.68 \mathrm{E}-13$ & $2.85 \mathrm{E}-08$ & $1.05 \mathrm{E}-13$ & $9.71 \mathrm{E}-11$ & 0.0 \\
\hline Ag- 110 & $0.0^{\mathrm{b}}$ & $0.0^{\mathrm{b}}$ & $0.0^{\mathrm{b}}$ & $0.0^{\mathrm{b}}$ & $0.0^{\mathrm{b}}$ & $1.78 \mathrm{E}-15$ \\
\hline $\mathrm{Ag}-110 \mathrm{~m}$ & $5.19 \mathrm{E}-09$ & 6.74 E-09 & $1.20 \mathrm{E}-07$ & 2.43 E-09 & $1.51 \mathrm{E}-08$ & $1.36 \mathrm{E}-13$ \\
\hline Cd-113m & $3.32 \mathrm{E}-08$ & $3.32 \mathrm{E}-08$ & $3.38 \mathrm{E}-08$ & $3.32 \mathrm{E}-08$ & $1.30 \mathrm{E}-06$ & $6.94 \mathrm{E}-18$ \\
\hline In-113m & $2.30 \mathrm{E}-12$ & $3.63 \mathrm{E}-12$ & $4.98 \mathrm{E}-11$ & $2.32 \mathrm{E}-12$ & $1.26 \mathrm{E}-11$ & $1.21 \mathrm{E}-14$ \\
\hline Sn-113 & 1.32 E-09 & $7.71 \mathrm{E}-10$ & 1.84 E-08 & $3.16 \mathrm{E}-10$ & $1.38 \mathrm{E}-09$ & $3.82 \mathrm{E}-16$ \\
\hline Sn-119m & 1.10 E-09 & 4.62 E-10 & $1.15 \mathrm{E}-08$ & $7.14 \mathrm{E}-11$ & $6.28 \mathrm{E}-10$ & $1.01 \mathrm{E}-16$ \\
\hline $\mathrm{Sn}-121 \mathrm{~m}$ & $4.06 \mathrm{E}-09$ & $1.50 \mathrm{E}-09$ & $2.08 \mathrm{E}-08$ & $1.97 \mathrm{E}-10$ & $1.10 \mathrm{E}-09$ & $6.20 \mathrm{E}-17$ \\
\hline Sn-123 & $3.75 \mathrm{E}-09$ & $1.36 \mathrm{E}-09$ & $6.11 \mathrm{E}-08$ & $1.81 \mathrm{E}-10$ & $3.70 \mathrm{E}-09$ & $4.03 \mathrm{E}-16$ \\
\hline $\mathrm{Sn}-126$ & $3.33 \mathrm{E}-08$ & $1.69 \mathrm{E}-08$ & $1.51 \mathrm{E}-07$ & 4.95 E-09 & $1.20 \mathrm{E}-08$ & $2.11 \mathrm{E}-15$ \\
\hline
\end{tabular}


Table 3-2. Organ Dose Factors from Inhalation and Air Submersion Dose Factors. (3 sheets)

\begin{tabular}{|c|c|c|c|c|c|c|}
\hline \multirow{2}{*}{ Nuclide } & \multicolumn{5}{|c|}{ Inhalation dose factors, $\mathrm{Sv} / \mathrm{Bq}^{\mathrm{a}}$} & \multirow{2}{*}{$\begin{array}{c}\text { Air } \\
\text { submersion } \\
(\mathrm{Sv} / \mathrm{s} \text { per } \\
\left.\mathrm{Bq} / \mathrm{m}^{3}\right)\end{array}$} \\
\hline & Bone surface & Red marrow & Lungs & Gonads & Remainder & \\
\hline Sb-125 & $9.78 \mathrm{E}-10$ & $5.35 \mathrm{E}-10$ & $2.17 \mathrm{E}-08$ & $3.60 \mathrm{E}-1.0$ & $1.45 \mathrm{E}-09$ & $2.02 \mathrm{E}-14$ \\
\hline $\mathrm{Sb}-126$ & $6.75 \mathrm{E}-10$ & $7.97 \mathrm{E}-10$ & $1.38 \mathrm{E}-08$ & $1.32 \mathrm{E}-09$ & $3.19 \mathrm{E}-09$ & $1.37 \mathrm{E}-13$ \\
\hline $\mathrm{Sb}-126 \mathrm{~m}$ & $1.32 \mathrm{E}-12$ & $1.46 \mathrm{E}-12$ & $5.04 \mathrm{E}-11$ & $1.19 \mathrm{E}-12$ & $7.92 \mathrm{E}-12$ & $7.50 \mathrm{E}-14$ \\
\hline $\mathrm{Te}-123 \mathrm{~m}$ & $6.09 \mathrm{E}-08$ & 5.79 E-09 & $6.05 \mathrm{E}-10$ & $2.77 \mathrm{E}-10$ & $4.75 \mathrm{E}-10$ & $6.51 \mathrm{E}-15$ \\
\hline $\mathrm{Te}-125 \mathrm{~m}$ & $1.18 \mathrm{E}-08$ & $1.15 \mathrm{E}-09$ & $1.04 \mathrm{E}-08$ & $7.93 \mathrm{E}-11$ & $6.75 \mathrm{E}-10$ & $4.53 \mathrm{E}-16$ \\
\hline Te-127 & $4.09 \mathrm{E}-12$ & $4.09 \mathrm{E}-12$ & $4.27 \mathrm{E}-10$ & $2.02 \mathrm{E}-12$ & $1.11 \mathrm{E}-10$ & $2.42 \mathrm{E}-16$ \\
\hline $\mathrm{Te}-127 \mathrm{~m}$ & 2.04 E-08 & $5.36 \mathrm{E}-09$ & $3.34 \mathrm{E}-08$ & $1.10 \mathrm{E}-10$ & $1.66 \mathrm{E}-09$ & $1.47 \mathrm{E}-16$ \\
\hline $\mathrm{I}-129$ & $1.38 \mathrm{E}-10$ & $1.40 \mathrm{E}-10$ & $3.14 \mathrm{E}-10$ & $8.69 \mathrm{E}-11$ & $1.18 \mathrm{E}-10$ & $3.80 \mathrm{E}-16$ \\
\hline Cs-134 & $1.10 \mathrm{E}-08$ & $1.18 \mathrm{E}-08$ & $1.18 \mathrm{E}-08$ & $1.30 \mathrm{E}-08$ & $1.39 \mathrm{E}-08$ & $7.57 \mathrm{E}-14$ \\
\hline Cs- 135 & $1.20 \mathrm{E}-09$ & $1.20 \mathrm{E}-09$ & 1.41 E-09 & 1.20 E-09 & 1.20 E-09 & 5.65 E-19 \\
\hline Cs- 137 & 7.94 E-09 & $8.30 \mathrm{E}-09$ & $8.82 \mathrm{E}-09$ & 8.76 E-09 & 9.12 E-09 & $7.74 \mathrm{E}-18$ \\
\hline $\mathrm{Ba}-137 \mathrm{~m}$ & $0.0^{\mathrm{b}}$ & $0.0^{\mathrm{b}}$ & $0.0^{\mathrm{b}}$ & $0.0^{6}$ & $0.0^{6}$ & $2.88 \mathrm{E}-14$ \\
\hline Ce-144 & 4.72 E-09 & $2.88 \mathrm{E}-09$ & 7.91 E-07 & $2.39 \mathrm{E}-10$ & $1.91 \mathrm{E}-08$ & 8.53 E-16 \\
\hline Pr-144 & $1.47 \mathrm{E}-14$ & $1.38 \mathrm{E}-14$ & 9.40 E-11 & $2.41 \mathrm{E}-15$ & $1.40 \mathrm{E}-12$ & $1.95 \mathrm{E}-15$ \\
\hline $\operatorname{Pr}-144 \mathrm{~m}$ & $0.0^{\mathrm{b}}$ & $0.0^{\mathrm{b}}$ & $0.0^{b}$ & $0.0^{\mathrm{b}}$ & $0.0^{\mathrm{b}}$ & $2.79 \mathrm{E}-16$ \\
\hline Pm- 147 & $2.01 \mathrm{E}-08$ & $1.61 \mathrm{E}-09$ & $7.74 \mathrm{E}-08$ & 8.25 E-15 & $1.56 \mathrm{E}-09$ & $6.93 \mathrm{E}-19$ \\
\hline Sm-151 & $1.38 \mathrm{E}-07$ & $1.10 \mathrm{E}-08$ & $3.26 \mathrm{E}-09$ & $4.03 \mathrm{E}-14$ & $7.51 \mathrm{E}-09$ & $3.61 \mathrm{E}-20$ \\
\hline Eu-152 & $2.40 \mathrm{E}-07$ & $7.91 \mathrm{E}-08$ & 5.76 E-08 & $1.31 \mathrm{E}-08$ & $9.99 \mathrm{E}-08$ & $5.65 \mathrm{E}-14$ \\
\hline Eu-154 & 5.23 E-07 & $1.06 \mathrm{E}-07$ & 7.92 E-08 & $1.17 \mathrm{E}-08$ & $1.13 \mathrm{E}-07$ & $6.14 \mathrm{E}-14$ \\
\hline Eu-155 & $1.52 \mathrm{E}-07$ & $1.43 \mathrm{E}-08$ & $1.19 \mathrm{E}-08$ & $3.56 \mathrm{E}-10$ & $1.11 \mathrm{E}-08$ & $2.49 \mathrm{E}-15$ \\
\hline Gd- 153 & $9.23 \mathrm{E}-08$ & $1.09 \mathrm{E}-08$ & 1.40 E-09 & $4.35 \mathrm{E}-10$ & $6.56 \mathrm{E}-09$ & $3.71 \mathrm{E}-15$ \\
\hline \multicolumn{7}{|c|}{ Actinides } \\
\hline U-234 & $1.13 \mathrm{E}-06$ & 7.22 E-08 & $2.98 \mathrm{E}-04$ & 2.65 E-09 & $1.06 \mathrm{E}-07$ & $7.63 \mathrm{E}-18$ \\
\hline U-235 & 1.05 E-06 & $7.15 \mathrm{E}-08$ & $2.76 \mathrm{E}-04$ & $2.85 \mathrm{E}-09$ & $1.02 \mathrm{E}-07$ & $7.72 \mathrm{E}-15$ \\
\hline U-236 & 1.07 E-06 & $6.83 \mathrm{E}-08$ & $2.82 \mathrm{E}-04$ & 2.51 E-09 & $1.00 \mathrm{E}-07$ & $5.01 \mathrm{E}-18$ \\
\hline U-238 & 1.01 E-06 & 6.91 E-08 & $2.66 \mathrm{E}-04$ & $2.44 \mathrm{E}-09$ & 1.02 E-07 & $1.21 \mathrm{E}-15$ \\
\hline
\end{tabular}


Table 3-2. Organ Dose Factors from Inhalation and Air Submersion Dose Factors. (3 sheets)

\begin{tabular}{|c|c|c|c|c|c|c|}
\hline \multirow{2}{*}{ Nuclide } & \multicolumn{5}{|c|}{ Inhalation dose factors, $\mathrm{Sv} / \mathrm{Bq}^{\mathrm{a}}$} & \multirow{2}{*}{$\begin{array}{c}\text { Air } \\
\text { submersion } \\
(\mathrm{Sv} / \mathrm{s} \text { per } \\
\left.\mathrm{Bq} / \mathrm{m}^{3}\right)\end{array}$} \\
\hline & Bone surface & Red marrow & Lungs & Gonads & Remainder & \\
\hline Np-237 & $3.27 \mathrm{E}-03$ & $2.62 \mathrm{E}-04$ & $1.61 \mathrm{E}-05$ & $2.96 \mathrm{E}-05$ & $2.34 \mathrm{E}-05$ & $1.04 \mathrm{E}-14$ \\
\hline $\mathrm{Pu}-238$ & $1.90 \mathrm{E}-03$ & $1.52 \mathrm{E}-04$ & $1.84 \mathrm{E}-05$ & $2.80 \mathrm{E}-05$ & $7.02 \mathrm{E}-05$ & $4.88 \mathrm{E}-18$ \\
\hline $\mathrm{Pu}-239$ & $2.11 \mathrm{E}-03$ & $1.69 \mathrm{E}-04$ & $1.73 \mathrm{E}-05$ & $3.18 \mathrm{E}-05$ & $7.56 \mathrm{E}-05$ & 4.24 E-18 \\
\hline $\mathrm{Pu}-240$ & $2.11 \mathrm{E}-03$ & $1.69 \mathrm{E}-04$ & $1.73 \mathrm{E}-05$ & $3.18 \mathrm{E}-05$ & $7.56 \mathrm{E}-05$ & $4.75 \mathrm{E}-18$ \\
\hline $\mathrm{Pu}-241$ & $4.20 \mathrm{E}-05$ & $3.36 \mathrm{E}-06$ & $7.42 \mathrm{E}-09$ & $6.82 \mathrm{E}-07$ & $1.31 \mathrm{E}-06$ & $2.19 \mathrm{E}-19$ \\
\hline $\mathrm{Pu}-242$ & $2.01 \mathrm{E}-03$ & $1.61 \mathrm{E}-04$ & $1.64 \mathrm{E}-05$ & $3.02 \mathrm{E}-05$ & $7.18 \mathrm{E}-05$ & $4.01 \mathrm{E}-18$ \\
\hline Am-241 & $2.17 \mathrm{E}-03$ & $1.74 \mathrm{E}-04$ & $1.84 \mathrm{E}-05$ & $3.25 \mathrm{E}-05$ & 7.82 E-05 & $8.18 \mathrm{E}-16$ \\
\hline Am-242 & $1.65 \mathrm{E}-07$ & $1.32 \mathrm{E}-08$ & $5.20 \mathrm{E}-08$ & $1.94 \mathrm{E}-09$ & 8.54 E-09 & $6.15 \mathrm{E}-16$ \\
\hline Am-242m & $2.12 \mathrm{E}-03$ & $1.69 \mathrm{E}-04$ & $4.20 \mathrm{E}-06$ & $3.21 \mathrm{E}-05$ & $7.48 \mathrm{E}-05$ & $1.61 \mathrm{E}-16$ \\
\hline $\mathrm{Am}-243$ & $2.17 \mathrm{E}-03$ & 1.73 E-04 & $1.78 \mathrm{E}-05$ & $3.26 \mathrm{E}-05$ & 7.74 E-05 & $9.87 \mathrm{E}-15$ \\
\hline $\mathrm{Cm}-242$ & $4.87 \mathrm{E}-05$ & $3.90 \mathrm{E}-06$ & $1.55 \mathrm{E}-05$ & $5.70 \mathrm{E}-07$ & $2.45 \mathrm{E}-06$ & $5.69 \mathrm{E}-18$ \\
\hline $\mathrm{Cm}-244$ & $1.17 \mathrm{E}-03$ & 9.38 E-05 & 1.93 E-05 & $1.59 \mathrm{E}-05$ & 4.78 E-05 & 4.91 E-18 \\
\hline
\end{tabular}

a'Inhalation dose factors are bounding values from Federal Guidance Report Number 11, 1988, Limiting Values of Radionuclide Intake and Air Concentration and Dose Conversion Factors for Inhalation, Submersion, and Ingestion, U.S. Environmental Protection Agency, Washington, D.C. The internal dose factor for tritium was increased by $50 \%$ to include skin absorption. Extemal dose rate factors are from Federal Guidance Report Number 12, 1993, External Exposure to Radionuclides in Air, Water, and Soil, U.S. Environmental Protection Agency, Washington, D.C. To convert $\mathrm{Sv} / \mathrm{Bq}$ to mrem/pCi multiply by 3,700 .

baughter products are included with parents and not tracked individually. Short half life progeny nuclides not shown are assumed to be in equilibrium with their parent nuclide. 
Table 3-3. Unit Dose Factors for Organs and for Air Submersion. (3 sheets)

\begin{tabular}{|c|c|c|c|c|c|c|}
\hline \multirow[b]{2}{*}{ Nuclide } & \multicolumn{6}{|c|}{ Organ and air submersion unit dose factors, $\mathrm{Sv} / \mathrm{g}^{\mathrm{a}}$} \\
\hline & Bone surface & Red marrow & Lungs & Gonads & Remainder & $\begin{array}{c}\text { Air } \\
\text { submersion }\end{array}$ \\
\hline \multicolumn{7}{|c|}{ Fission and activation products } \\
\hline $\mathrm{H}-3$ & $2.51 \mathrm{E}-05$ & $2.51 \mathrm{E}-05$ & $2.51 \mathrm{E}-05$ & $2.51 \mathrm{E}-05$ & $2.51 \mathrm{E}-05$ & $9.59 \mathrm{E}-10$ \\
\hline C-14 & $1.15 \mathrm{E}-05$ & $1.15 \mathrm{E}-05$ & $1.15 \mathrm{E}-05$ & $1.15 \mathrm{E}-05$ & $1.15 \mathrm{E}-05$ & $1.37 \mathrm{E}-11$ \\
\hline Fe-55 & $1.03 \mathrm{E}-05$ & $1.03 \mathrm{E}-05$ & $1.04 \mathrm{E}-05$ & 1.05 E-05 & 2.42 E-05 & 0.0 \\
\hline Co-60 & $1.04 \mathrm{E}-03$ & $1.33 \mathrm{E}-03$ & $2.67 \mathrm{E}-02$ & $3.68 \mathrm{E}-04$ & $2.78 \mathrm{E}-03$ & $2.92 \mathrm{E}-05$ \\
\hline Ni-59 & $8.53 \mathrm{E}-07$ & $8.60 \mathrm{E}-07$ & $8.40 \mathrm{E}-07$ & $8.74 \mathrm{E}-07$ & $8.62 \mathrm{E}-07$ & 0.0 \\
\hline $\mathrm{Ni}-63$ & $2.18 \mathrm{E}-04$ & $2.18 \mathrm{E}-04$ & $2.22 \mathrm{E}-04$ & $2.18 \mathrm{E}-04$ & $2.18 \mathrm{E}-04$ & 0.0 \\
\hline Se-79 & $1.45 \mathrm{E}-06$ & 1.45 E-06 & 2.37 E-05 & $1.45 \mathrm{E}-06$ & $9.12 \mathrm{E}-06$ & $2.20 \mathrm{E}-12$ \\
\hline $\mathrm{Kr}-85$ & 0.0 & 0.0 & 0.0 & 0.0 & 0.0 & $4.89 \mathrm{E}-06$ \\
\hline Sr-90 & $1.86 \mathrm{E}+02$ & $8.62 \mathrm{E}+01$ & $9.56 \mathrm{E}-01$ & $6.77 \mathrm{E}-01$ & $8.62 \mathrm{E}-01$ & $5.79 \mathrm{E}-06$ \\
\hline$Y-90$ & $3.87 \mathrm{E}-03$ & $3.90 \mathrm{E}-03$ & $2.39 \mathrm{E}+00$ & $1.33 \mathrm{E}-04$ & $9.92 \mathrm{E}-01$ & $1.46 \mathrm{E}-04$ \\
\hline Zr-93 & $2.38 \mathrm{E}-02$ & $1.93 \mathrm{E}-03$ & $9.47 \mathrm{E}-07$ & $2.38 \mathrm{E}-07$ & $9.26 \mathrm{E}-07$ & 0.0 \\
\hline $\mathrm{Nb}-93 \mathrm{~m}$ & $2.03 \mathrm{E}-06$ & $8.14 \mathrm{E}-07$ & 4.61 E-04 & 1.11 E-06 & $2.17 \mathrm{E}-06$ & $9.51 \mathrm{E}-11$ \\
\hline Tc-99 & $3.23 \mathrm{E}-06$ & $3.23 \mathrm{E}-06$ & $1.35 \mathrm{E}-03$ & $3.23 \mathrm{E}-06$ & $5.07 \mathrm{E}-05$ & $3.94 \mathrm{E}-10$ \\
\hline Ru-106 & $1.52 \mathrm{E}-06$ & $1.67 \mathrm{E}-06$ & $9.85 \mathrm{E}-04$ & $1.23 \mathrm{E}-06$ & $1.14 \mathrm{E}-05$ & 0.0 \\
\hline Rh-106 & $0.0^{\mathrm{b}}$ & $0.0^{\mathrm{b}}$ & $0.0^{\mathrm{b}}$ & $0.0^{\mathrm{b}}$ & $0.0^{\mathrm{b}}$ & $2.96 \mathrm{E}-08$ \\
\hline Pd-107 & $8.72 \mathrm{E}-10$ & $3.28 \mathrm{E}-10$ & $1.65 \mathrm{E}-05$ & $6.06 \mathrm{E}-11$ & $5.60 \mathrm{E}-08$ & 0.0 \\
\hline Ag-110 & $0.0^{\mathrm{b}}$ & $0.0^{\mathrm{b}}$ & $0.0^{\mathrm{b}}$ & $0.0^{\mathrm{b}}$ & $0.0^{6}$ & $1.42 \mathrm{E}-16$ \\
\hline Ag- $110 \mathrm{~m}$ & $1.04 \mathrm{E}-11$ & $1.34 \mathrm{E}-11$ & $2.39 \mathrm{E}-10$ & $4.85 \mathrm{E}-12$ & $3.01 \mathrm{E}-11$ & $8.14 \mathrm{E}-13$ \\
\hline Cd-113m & $3.41 \mathrm{E}-03$ & $3.41 \mathrm{E}-03$ & $3.48 \mathrm{E}-03$ & $3.41 \mathrm{E}-03$ & $1.34 \mathrm{E}-01$ & 2.14 E-09 \\
\hline In- $113 m$ & $1.16 \mathrm{E}-26$ & $1.83 \mathrm{E}-26$ & $2.51 \mathrm{E}-25$ & $1.17 \mathrm{E}-26$ & $6.34 \mathrm{E}-26$ & $1.83 \mathrm{E}-25$ \\
\hline Sn-113 & $6.64 \mathrm{E}-24$ & $3.88 \mathrm{E}-24$ & $9.26 \mathrm{E}-23$ & $1.59 \mathrm{E}-24$ & $6.94 \mathrm{E}-24$ & $5.77 \mathrm{E}-27$ \\
\hline Sn-119m & $2.50 \mathrm{E}-12$ & $1.05 \mathrm{E}-12$ & $2.61 \mathrm{E}-11$ & $1.62 \mathrm{E}-13$ & $1.43 \mathrm{E}-12$ & $6.88 \mathrm{E}-16$ \\
\hline Sn-121m & $9.42 \mathrm{E}-06$ & $3.47 \mathrm{E}-06$ & $4.83 \mathrm{E}-05$ & $4.56 \mathrm{E}-07$ & $2.55 \mathrm{E}-06$ & $4.32 \mathrm{E}-10$ \\
\hline Sn-123 & $2.39 \mathrm{E}-20$ & $8.66 \mathrm{E}-21$ & 3.89 E-19 & $1.15 \mathrm{E}-21$ & $2.35 \mathrm{E}-20$ & $7.69 \mathrm{E}-24$ \\
\hline Sn-126 & $1.59 \mathrm{E}-04$ & 8.07 E-05 & $7.21 \mathrm{E}-04$ & $2.36 \mathrm{E}-05$ & $5.73 \mathrm{E}-05$ & 3.02 E-08 \\
\hline Sb-125 & 0.0 & 0.0 & 0.0 & 0.0 & 0.0 & 0.0 \\
\hline
\end{tabular}


HNF-SD-SNF-TI-059 REV 2

Table 3-3. Unit Dose Factors for Organs and for Air Submersion. (3 sheets)

\begin{tabular}{|c|c|c|c|c|c|c|}
\hline \multirow[b]{2}{*}{ Nuclide } & \multicolumn{6}{|c|}{ Organ and air submersion unit dose factors, $\mathrm{Sv} / \mathrm{g}^{\mathrm{a}}$} \\
\hline & Bone surface & Red marrow & Lungs & Gonads & Remainder & $\begin{array}{c}\text { Air } \\
\text { submersion }\end{array}$ \\
\hline $\mathrm{Sb}-126$ & $4.52 \mathrm{E}-07$ & $5.34 \mathrm{E}-07$ & $9.24 \mathrm{E}-06$ & $8.84 \mathrm{E}-07$ & $2.14 \mathrm{E}-06$ & $2.75 \mathrm{E}-07$ \\
\hline $\mathrm{Sb}-126 \mathrm{~m}$ & $6.30 \mathrm{E}-09$ & $6.97 \mathrm{E}-09$ & $2.41 \mathrm{E}-07$ & $5.68 \mathrm{E}-09$ & $3.78 \mathrm{E}-08$ & $1.07 \mathrm{E}-06$ \\
\hline $\mathrm{Te}-123 \mathrm{~m}$ & $3.38 \mathrm{E}-24$ & $3.21 \mathrm{E}-25$ & 3.36 E-26 & $1.54 \mathrm{E}-26$ & $2.64 \mathrm{E}-26$ & $1.08 \mathrm{E}-27$ \\
\hline $\mathrm{Te}-125 \mathrm{~m}$ & 0.0 & 0.0 & 0.0 & 0.0 & 0.0 & 0.0 \\
\hline Te-127 & $3.21 \mathrm{E}-26$ & $3.21 \mathrm{E}-26$ & $3.35 \mathrm{E}-24$ & $1.58 \mathrm{E}-26$ & $8.71 \mathrm{E}-25$ & $5.69 \mathrm{E}-27$ \\
\hline $\mathrm{Te}-127 \mathrm{~m}$ & $1.63 \mathrm{E}-22$ & $4.28 \mathrm{E}-23$ & $2.67 \mathrm{E}-22$ & $8.79 \mathrm{E}-25$ & $1.33 \mathrm{E}-23$ & $3.52 \mathrm{E}-27$ \\
\hline I-129 & $2.63 \mathrm{E}-08$ & $2.67 \mathrm{E}-08$ & $5.99 \mathrm{E}-08$ & $1.66 \mathrm{E}-08$ & $2.25 \mathrm{E}-08$ & $2.18 \mathrm{E}-10$ \\
\hline $\mathrm{Cs}-134$ & 2.63 E-03 & $2.82 \mathrm{E}-03$ & $2.82 \mathrm{E}-03$ & $3.11 \mathrm{E}-03$ & $3.33 \mathrm{E}-03$ & 5.44 E-05 \\
\hline Cs- 135 & $2.68 \mathrm{E}-06$ & $2.68 \mathrm{E}-06$ & $3.15 \mathrm{E}-06$ & $2.68 \mathrm{E}-06$ & $2.68 \mathrm{E}-06$ & $3.79 \mathrm{E}-12$ \\
\hline Cs-137 & $2.84 \mathrm{E}+00$ & $2.97 \mathrm{E}+00$ & $3.15 \mathrm{E}+00$ & $3.13 E+00$ & $3.26 \mathrm{E}+00$ & $8.30 \mathrm{E}-06$ \\
\hline $\mathrm{Ba}-137 \mathrm{~m}$ & $0.0^{\mathrm{b}}$ & $0.0^{\mathrm{b}}$ & $0.0^{\mathrm{b}}$ & $0.0^{\mathbf{b}}$ & $0.0^{\mathrm{b}}$ & 2.92 E-02 \\
\hline $\mathrm{Ce}-144$ & $1.38 \mathrm{E}-07$ & 8.43 E-08 & $2.32 \mathrm{E}-05$ & $6.99 \mathrm{E}-09$ & $5.59 \mathrm{E}-07$ & $7.49 \mathrm{E}-11$ \\
\hline Pr-144 & $4.25 \mathrm{E}-13$ & $3.99 \mathrm{E}-13$ & 2.72 E-09 & $6.97 \mathrm{E}-14$ & $4.05 \mathrm{E}-11$ & 1.69 E-10 \\
\hline $\operatorname{Pr}-144 \mathrm{~m}$ & $0.0^{\mathrm{b}}$ & $0.0^{\mathrm{b}}$ & $0.0^{\mathrm{b}}$ & $0.0^{\mathrm{b}}$ & $0.0^{\mathrm{b}}$ & $2.94 \mathrm{E}-13$ \\
\hline Pm-147 & 8.11 E-02 & $6.49 \mathrm{E}-03$ & $3.12 \mathrm{E}-01$ & $3.33 \mathrm{E}-08$ & $6.29 \mathrm{E}-03$ & 8.38 E-09 \\
\hline Sm- 151 & $5.21 \mathrm{E}-01$ & $4.15 \mathrm{E}-02$ & $1.23 \mathrm{E}-02$ & $1.52 \mathrm{E}-07$ & $2.83 \mathrm{E}-02$ & $4.09 \mathrm{E}-10$ \\
\hline Eu-152 & $7.50 \mathrm{E}-03$ & $2.47 \mathrm{E}-03$ & $1.80 \mathrm{E}-03$ & $4.10 \mathrm{E}-04$ & $3.12 \mathrm{E}-03$ & 5.30 E-06 \\
\hline Eu-154 & $2.19 \mathrm{E}+00$ & $4.43 \mathrm{E}-01$ & $3.31 \mathrm{E}-01$ & $4.89 \mathrm{E}-02$ & 4.72 E-01 & $7.70 \mathrm{E}-04$ \\
\hline Eu-155 & $5.96 \mathrm{E}-02$ & $5.61 \mathrm{E}-03$ & $4.67 \mathrm{E}-03$ & $1.40 \mathrm{E}-04$ & $4.35 \mathrm{E}-03$ & $2.93 \mathrm{E}-06$ \\
\hline Gd-153 & $1.77 \mathrm{E}-21$ & $2.09 \mathrm{E}-22$ & $2.69 \mathrm{E}-23$ & 8.35 E-24 & $1.26 \mathrm{E}-22$ & $2.14 \mathrm{E}-25$ \\
\hline Subtotal: & $1.92 \mathrm{E}+02$ & $8.96 \mathrm{E}+01$ & $7.19 \mathrm{E}+00$ & $3.86 \mathrm{E}+00$ & $5.77 \mathrm{E}+00$ & $3.02 \mathrm{E}-02$ \\
\hline \multicolumn{7}{|c|}{ Actinides } \\
\hline U-234 & $1.61 \mathrm{E}-02$ & 1.03 E-03 & $4.23 \mathrm{E}+00$ & 3.77 E-05 & $1.51 \mathrm{E}-03$ & $3.25 \mathrm{E}-10$ \\
\hline $\mathrm{U}-235$ & $4.93 \mathrm{E}-04$ & $3.36 \mathrm{E}-05$ & 1.30 E-01 & $1.34 \mathrm{E}-06$ & $4.81 \mathrm{E}-05$ & $1.09 \mathrm{E}-08$ \\
\hline $\mathrm{U}-236$ & $2.83 \mathrm{E}-03$ & $1.81 \mathrm{E}-04$ & 7.47 E-01 & $6.65 \mathrm{E}-06$ & $2.65 \mathrm{E}-04$ & $3.98 \mathrm{E}-11$ \\
\hline U-238 & $1.24 \mathrm{E}-02$ & 8.46 E-04 & $3.26 \mathrm{E}+00$ & $2.99 \mathrm{E}-05$ & $1.25 \mathrm{E}-03$ & 4.45 E-08 \\
\hline $\mathrm{Np}-237$ & $5.64 \mathrm{E}+00$ & $4.52 \mathrm{E}-01$ & $2.78 \mathrm{E}-02$ & $5.10 \mathrm{E}-02$ & $4.03 \mathrm{E}-02$ & 5.37 E-08 \\
\hline
\end{tabular}


Table 3-3. Unit Dose Factors for Organs and for Air Submersion. (3 sheets)

\begin{tabular}{|l|c|c|c|c|c|c|}
\hline \multirow{3}{*}{ Nuclide } & \multicolumn{5}{|c|}{ Organ and air submersion unit dose factors, Sv/ga } \\
\cline { 2 - 7 } & Bone surface & Red marrow & Lungs & Gonads & Remainder & $\begin{array}{c}\text { Air } \\
\text { submersion }\end{array}$ \\
\hline Pu-238 & $9.35 \mathrm{E}+03$ & $7.48 \mathrm{E}+02$ & $9.05 \mathrm{E}+01$ & $1.38 \mathrm{E}+02$ & $3.45 \mathrm{E}+02$ & $7.20 \mathrm{E}-08$ \\
\hline Pu-239 & $1.35 \mathrm{E}+04$ & $1.08 \mathrm{E}+03$ & $1.11 \mathrm{E}+02$ & $2.04 \mathrm{E}+02$ & $4.84 \mathrm{E}+02$ & $8.14 \mathrm{E}-08$ \\
\hline Pu-240 & $1.07 \mathrm{E}+04$ & $8.57 \mathrm{E}+02$ & $8.77 \mathrm{E}+01$ & $1.61 \mathrm{E}+02$ & $3.83 \mathrm{E}+02$ & $7.22 \mathrm{E}-08$ \\
\hline Pu-241 & $1.06 \mathrm{E}+04$ & $8.48 \mathrm{E}+02$ & $1.87 \mathrm{E}+00$ & $1.72 \mathrm{E}+02$ & $3.31 \mathrm{E}+02$ & $1.66 \mathrm{E}-07$ \\
\hline Pu-242 & $6.48 \mathrm{E}+00$ & $5.19 \mathrm{E}-01$ & $5.29 \mathrm{E}-02$ & $9.73 \mathrm{E}-02$ & $2.31 \mathrm{E}-01$ & $3.88 \mathrm{E}-11$ \\
\hline Am-241 & $3.48 \mathrm{E}+04$ & $2.79 \mathrm{E}+03$ & $2.95 \mathrm{E}+02$ & $5.22 \mathrm{E}+02$ & $1.26 \mathrm{E}+03$ & $3.94 \mathrm{E}-05$ \\
\hline Am-242 & $2.26 \mathrm{E}-03$ & $1.81 \mathrm{E}-04$ & $7.14 \mathrm{E}-04$ & $2.66 \mathrm{E}-05$ & $1.17 \mathrm{E}-04$ & $2.53 \mathrm{E}-08$ \\
\hline Am-242m & $2.92 \mathrm{E}+01$ & $2.33 \mathrm{E}+00$ & $5.78 \mathrm{E}-02$ & $4.42 \mathrm{E}-01$ & $1.03 \mathrm{E}+00$ & $6.66 \mathrm{E}-09$ \\
\hline Am-243 & $2.23 \mathrm{E}+01$ & $1.78 \mathrm{E}+00$ & $1.83 \mathrm{E}-01$ & $3.35 \mathrm{E}-01$ & $7.96 \mathrm{E}-01$ & $3.05 \mathrm{E}-07$ \\
\hline Cm-242 & $5.55 \mathrm{E}-01$ & $4.44 \mathrm{E}-02$ & $1.77 \mathrm{E}-01$ & $6.50 \mathrm{E}-03$ & $2.79 \mathrm{E}-02$ & $1.95 \mathrm{E}-10$ \\
\hline Cm-244 & $1.94 \mathrm{E}+02$ & $1.55 \mathrm{E}+01$ & $3.19 \mathrm{E}+00$ & $2.63 \mathrm{E}+00$ & $7.91 \mathrm{E}+00$ & $2.44 \mathrm{E}-09$ \\
\hline Subtotal: & $7.93 \mathrm{E}+04$ & $6.35 \mathrm{E}+03$ & $5.98 \mathrm{E}+02$ & $1.20 \mathrm{E}+03$ & $2.81 \mathrm{E}+03$ & $4.02 \mathrm{E}-05$ \\
\hline \hline SNF Total: & $7.94 \mathrm{E}+04$ & $6.44 \mathrm{E}+03$ & $6.06 \mathrm{E}+02$ & $1.20 \mathrm{E}+03$ & $2.81 \mathrm{E}+03$ & $3.03 \mathrm{E}-02$ \\
\hline
\end{tabular}

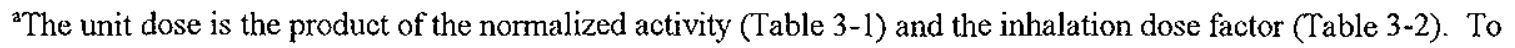
convert $\mathrm{Sv} / \mathrm{g}$ to rem/g multiply by 100 . The values shown for air submersion are the external dose rate factor for submersion in an infinite cloud (Table 3-2) divided by the light activity breathing rate and multiplied by the normalized activity (Table 3-1).

bDaughter products are included with parents and not tracked individually. Short half life progeny nuclides not shown are assumed to be in equilibrium with their parent nuclide. 
Separate occupational exposure limits were provided in ICRP Publication 26 for the EDE and the organs to limit both stochastic and non-stochastic effects. Stochastic effects are biological effects whose probability depends on the dose, but whose severity does not. An example of a stochastic effect is the development of a fatal cancer. The EDE is a measure of the probability of a fatal cancer developing due to exposure to ionizing radiation. Non-stochastic effects are the result of too much dose to specific organs, leading to some symptoms of tissue damage. For non-stochastic effects the severity depends on the dose, and there normally is a threshold below which there is no effect. Examples of non-stochastic effects in persons exposed to large radiation doses from World War II atomic bombs and therapeutic radiation exposures was published in ICRP Publication 41, Non-Stochastic Effects of Ionizing Radiation. From a health standpoint, the exposure threshold values reported in ICRP Publication 41 are high enough that radiation dose can be effectively controlled using only the EDE. The 50 rem organ limit is unnecessary.

The guidance from DOE-RL presented (Table 1-1) only limits EDE. Organ dose limits are not given. NRC compliance then requires that the postulated DBAs have site boundary EDE values less than $2.8 \mathrm{rem}$. This value is lower than the guidelines given in Table 1-1 for "unlikely" and "extremely unlikely" events. Events considered "anticipated" have DOE limits that are lower than the NRC equivalent.

\subsection{RADIOLOGICAL EXPOSURE PATHWAYS}

Two general exposure pathways associated with accidental releases of radioactive materials are internal and external. Internal exposure occurs when radioactive materials get inside the body. External exposure is received from radioactive materials outside the body. The total radiation dose received by a receptor downwind is equal to the sum of the dose contributions from the internal and external exposure pathways. In this section, the internal is divided into inhalation and ingestion contributions. The pathway of concern for SNF is the inhalation pathway. The external pathway is divided into contributions from air submersion and ground deposition. Neither external pathway is a significant contributor to total dose. Another route of entry is injection through cuts in the skin. This last one will not be considered, because it assumes additional accidents take place at the receptor location at the time of the postulated SNF accident. This represents a low probability due to the small time window.

\subsubsection{Inhalation Pathway}

The major internal exposure pathway for accidents occurring at the SNF Project facilities is the inhalation pathway. Exposure through the inhalation pathway occurs when an accident results in a release of airborne radioactive materials that are transported downwind and inhaled, or when radioactive materials that have been deposited on the ground during plume passage become resuspended and subsequently inhaled.

Inhalation Dose During Plume Passage. The calculation of inhalation dose from a mixture of radionuclides transported downwind is computed as the sum of the products of the 
quantity released, the air transport factor, the inhalation rate, and the unit dose factor for the radionuclide released. This is summarized in the following equation.

$$
\mathrm{DE}_{\mathrm{TNHALE}}=\sum_{\mathrm{K}}\left(\mathrm{QK}_{\mathrm{K}}\right)\left(\chi / \mathrm{Q}^{\prime}\right)(\mathrm{BR})(\mathrm{DFK})
$$

where

$$
\begin{aligned}
\mathrm{DE}_{\mathrm{INHALE}} & =50 \text {-year committed EDE from inhalation of a mixture of nuclides, } \mathrm{Sv} \\
\mathrm{Q}_{\mathrm{K}} & =\text { activity of the Kth nuclide released into the air as respirable particles, } \mathrm{Bq} \\
\chi / \mathrm{Q}^{\prime} & =\text { air transport factor, } \mathrm{s} / \mathrm{m}^{3} \\
\mathrm{BR} & =\text { average inhalation rate during the release, } \mathrm{m}^{3} / \mathrm{s} \\
\mathrm{DF}_{\mathrm{K}} & =50 \text {-year committed EDE per unit activity inhaled of the Kth nuclide, } \mathrm{Sv} / \mathrm{Bq}
\end{aligned}
$$

Inhalation dose factors $\left(\mathrm{DF}_{\mathrm{K}}\right)$ are taken from Federal Guidance Report No. 11. For nuclides with more than one biological lung clearance class, the class that gives the largest dose factor is used unless clear justification for non-conservative values can be provided. For example, Sr-90 has both class D and class $Y$ dose factors and the class $Y$ is larger. However, the class $Y$ material is only for a compound, $\mathrm{SrTiO}_{3}$, that is not found in SNF. Therefore, class D is used for Sr-90.

Inhalation rates (BR) for the reference man (ICRP Publication 23) are used. The light activity breathing rate $\left(1.2 \mathrm{~m}^{3} / \mathrm{hr}\right.$ or $\left.3.33 \times 10^{-4} \mathrm{~m}^{3} / \mathrm{s}\right)$ normally applies during the first 16 hours of the day when the man is assumed to be awake. The resting breathing rate $\left(0.45 \mathrm{~m}^{3} / \mathrm{hr}\right.$ or $1.25 \times 10^{-4} \mathrm{~m}^{3} / \mathrm{s}$ ) applies during the last 8 hours of the day when the man is assumed to be asleep. The 24-hour average breathing rate is $2.64 \times 10^{-4} \mathrm{~m}^{3} / \mathrm{s}$. Note that the adult male breathing rate is used rather than the adult female breathing rate to maximize the intake and also the dose from SNF.

The air transport factor $\left(\chi / Q^{\prime}\right)$ depends on which receptor is being considered, the release height, and the duration of the release. Values are given in Tables 2-4 and 2-5.

The quantity released is based on the accident scenario. Since only the respirable portion contributes to inhalation dose, the value for $\mathrm{Q}_{\mathrm{K}}$ is limited to the respirable portion. If this is not known, then the entire release should be assumed to be respirable. Note that if the various activities released are those found in a certain number of grams of SNF (M), then the equation can be written as

$$
\begin{gathered}
\mathrm{DE}_{\mathrm{TNHALE}}=\sum_{\mathrm{K}}(\mathrm{M})\left(\mathrm{UQ}_{\mathrm{K}}\right)\left(\chi / \mathrm{Q}^{\prime}\right)(\mathrm{BR})(\mathrm{DFK}) \\
\mathrm{DE}_{\mathrm{TNHALE}}=(\mathrm{M})\left(\chi / \mathrm{Q}^{\prime}\right)(\mathrm{BR})(\mathrm{UD})
\end{gathered}
$$


where

$$
\begin{aligned}
\mathrm{DE}_{\mathrm{INHALE}}= & 50 \text {-year committed EDE from inhalation of a mixture of nuclides, } \mathrm{Sv} \\
\mathrm{M}= & \text { mass of SNF released into the air as respirable particles, } \mathrm{g} \\
\mathrm{UQ}_{\mathrm{K}}= & \text { activity of the Kth nuclide per unit mass of } \mathrm{SNF}, \mathrm{Bq} / \mathrm{g} \\
\chi / \mathrm{Q}^{\prime}= & \text { air transport factor, } \left.\mathrm{s} / \mathrm{m}^{3} \text { (Tables } 2-4 \text { and } 2-5\right) \\
\mathrm{BR}= & \text { average inhalation rate during the release, } \mathrm{m}^{3} / \mathrm{s} \\
\mathrm{DF}_{\mathrm{K}}= & 50 \text {-year committed EDE per unit activity inhaled of the Kth nuclide, } \mathrm{Sv} / \mathrm{Bq} \\
& (\text { Table } 3-1) \\
\mathrm{UD}= & 50 \text {-year committed EDE from inhalation of a unit mass of SNF as respirable } \\
& \text { particles, } 4380 \mathrm{~Sv} / \mathrm{g}(\text { Table } 3-1)
\end{aligned}
$$

An additional consideration for certain downwind receptors is occupancy time, the period out of the total release duration that they are actually exposed. Onsite workers and onsite members of the public can be exposed for as many as 12 hours if they are not evacuated. For release durations longer than 1 day, the typical 8-hour per day exposure schedule should be used. For example, if a continuous release lasts 24 hours then the dose to onsite individuals should be modeled using the 12-hour $\chi / Q^{\prime}$ along with the activity released during the first 12 hours. Dose to the offsite individual should be modeled using the 24-hour $\chi / Q^{\prime}$ along with the total activity released during the 24 hours.

The selection of 12 hours as the bounding case exposure duration for the onsite worker finds a compromise between the single shift of the majority of the Hanford workforce and a double shift occasionally worked by a few. The air transport factors for 16 -hour releases are just $24 \%$ lower than the air transport factors for 8-hour releases. A constant release rate leads to onsite worker doses for 16 -hour releases that are $53 \%$ higher than the 8 -hour doses. Selecting 12 hours as the onsite maximum presents a realistic worst-case exposure time that does consider the effect of additional dose during extra work hours.

Inhalation Dose from Resuspension of Deposited Material. The airborne emission not only leads to an inhalation dose at the receptor location while the plume passes, but also some long-term inhalation due to resuspended activity. Since inhalation dose from resuspended particulate is accumulated over an extended period of time following the accident, it can be estimated using a resuspension model. The dose from inhalation of resuspended activity is a small addition to the dose from inhalation of the passing plume. This is demonstrated in the discussion below by constructing a ratio of inhalation doses.

To estimate dose from resuspended material, one first needs an estimate of how much can be resuspended. It will be assumed that the average air concentration of resuspended material is proportional to the concentration deposited on the ground surface. The constant of proportionality is called a resuspension factor. A bounding value is $1 \times 10^{-5}$ per meter (DOE-HDBK-3010-94, Figure 4-22). Doses are computed using the formula below. 


$$
\mathrm{DE}_{\mathrm{NH}, \mathrm{RES}}=\sum_{\mathrm{K}}(\mathrm{SK})(\mathrm{R})(\mathrm{BR})\left(\mathrm{T}_{\mathrm{B}}\right)(\mathrm{DFK})
$$

where

$$
\begin{aligned}
\mathrm{DE}_{\mathrm{INH}, \mathrm{RES}} & =50 \text {-year committed EDE from inhalation of resuspended activity, } \mathrm{Sv} \\
\mathrm{S}_{\mathrm{K}} & =\text { surface concentration of the Kth nuclide, } \mathrm{Bq} / \mathrm{m}^{2} \\
\mathrm{R} & =\text { resuspension factor, } 1 \times 10^{-5} \text { per meter } \\
\mathrm{BR} & =\text { average inhalation rate during the exposure period, } \mathrm{m}^{3} / \mathrm{s} \\
\mathrm{T}_{\mathrm{B}} & =\text { period during which the resuspended activity is inhaled, } \mathrm{s} \\
\mathrm{DF}_{\mathrm{K}} & =50 \text {-year committed EDE per unit activity inhaled of the Kth nuclide, } \mathrm{Sv} / \mathrm{Bq} .
\end{aligned}
$$

Note that the breathing rates in the two inhalation dose equations could be different. For a short-duration release followed by a week of resuspension, the light activity breathing rate applies to the inhalation dose from plume passage, while the daily average breathing rate applies to the inhalation dose from resuspension.

Surface contamination from the passing plume is the result of deposition on the ground surface. Ground deposition a the low rates typical of respirable particles is modeled using the formula below.

$$
S_{K}=\left(Q_{K}\right)\left(\chi / Q^{\prime}\right)\left(V_{K}\right)
$$

where

$$
\begin{aligned}
\mathrm{S}_{\mathrm{K}} & =\text { surface concentration of the Kth nuclide, } \mathrm{Bq} / \mathrm{m}^{2} \\
\mathrm{Q}_{\mathrm{K}} & =\text { activity of the Kth nuclide released into the air as respirable particles, } \mathrm{Bq} \\
\chi / \mathrm{Q}^{\prime} & =\text { air transport factor, } \mathrm{s} / \mathrm{m}^{3} \\
\mathrm{~V}_{\mathrm{K}} & =\text { ground surface deposition speed for the } \mathrm{K} \text { th nuclide, } \mathrm{m} / \mathrm{s} .
\end{aligned}
$$

For the nuclides of interest in SNF, the ground deposition speed is $0.001 \mathrm{~m} / \mathrm{s}$. Inserting the surface activity equation into the resuspended dose equation and dividing this by the plume inhalation dose equation leads to the result shown below.

$$
\begin{gathered}
\left(\mathrm{DE}_{\mathrm{TNH}, \mathrm{RES}}\right) /\left(\mathrm{DE}_{\mathrm{TNHALE}}\right)=(\mathrm{V})(\mathrm{R})\left(\mathrm{T}_{\mathrm{B}}\right)\left(\mathrm{BR}_{\mathrm{RESUS}}\right) /\left(\mathrm{BR}_{\mathrm{PLUME}}\right) \\
=(0.001 \mathrm{~m} / \mathrm{s})\left(1 \times 10^{-5} \mathrm{~m}^{-1}\right)\left(3.15 \times 10^{7} \mathrm{~s}\right)\left(2.64 \times 10^{-4} \mathrm{~m}^{3} / \mathrm{s}\right) /\left(3.33 \times 10^{-4} \mathrm{~m}^{3} / \mathrm{s}\right) \\
=0.25
\end{gathered}
$$


If the exposure period is 1 year following the postulated accident, the ratio of resuspension dose to plume dose is 0.25 , which is not negligible. Two additional considerations allow it to be discarded. The first is weathering effects on the surface contamination. The second is the assumed exposure time of the individual spending time in the contamination.

Weathering of the surface contamination refers to migration by wind and precipitation stresses into locations that are not exposed to the surface air. Weathering causes the surface activity to become unavailable for resuspension. In effect, the surface activity decreases with time, which lowers the inhalation dose from resuspended activity. The GENII software was also used to provide a more sophisticated estimate of resuspension dose. The time-dependent resuspension model in GENII (known as the Anspaugh resuspension model) includes the effects of weathering, but also starts at a higher initial resuspension factor. From GENII (see next section), the ratio of inhalation dose from resuspended activity to inhalation dose from the plume is 0.14 .

The assumed exposure period of 1 year is unlikely. Any measurable contamination on the ground following an accidental release would be removed before the general workforce could have access to the area. In addition, the Hanford Site dosimetry program is set up to detect elevated external dose rates and elevated bioassay results (i.e., internal contamination of workers from radioactivity in their work environment). Offsite individuals would be warned to evacuate areas with measurable surface contamination, according to current emergency plans for the Hanford Site (DOE-0223, WSDOA 1994, WSDOH 1993, EPA 1992). Thus the dose from resuspended activity is a small addition to the total inhalation dose, and will not be considered.

\subsubsection{Ingestion Pathway}

The other internal exposure pathway is the ingestion pathway. Exposure through the ingestion pathway occurs when radioactive materials that have been deposited offsite are ingested. An example is activity deposited on vegetable produce that is collected and eaten the day of the accident. Another example is activity deposited on grass that is consumed by a cow, transferred to the cow's milk, and consumed the day of the accident. Intake of contaminated food is assumed to end after the first day as a result of state and federal programs in place to prevent ingestion of contaminated food and water in the event of an accident (DOE-0223, WSDOA 1994, WSDOH 1993, EPA 1992). The primary determinant of exposure from the ingestion pathway is the effectiveness of public health measures (i.e., interdiction) rather than the severity of the accident itself.

The ingestion pathway, if it occurs, is a slow-to-develop pathway and is not considered an immediate threat to an exposed population in the same sense as airborne plume exposures. The first day's ingestion dose is estimated below using the GENII software (PNL-6584). The ingestion dose turns out to be less than $1 \%$ of the dose from inhalation. Therefore, the ingestion pathway is not included in calculations of the radiological dose for comparison against the risk evaluation criteria. 
The approach used to estimate bounding ingestion doses for the first day after an accident is similar to that used in tank waste calculations (WHC-SD-WM-SAR-016). The GENII software (PNL-6584) is used to estimate this dose contribution. The GENII internal dose factors differ slightly from those developed by the U.S. Environmental Protection Agency (Federal Guidance Report No. 11). This difference does not affect the conclusion that 24 hour ingestion dose is small compared to the inhalation dose from the passing plume. below.

The title lines from the data libraries used by the GENII code in these calculations are listed

- GENII Default Parameter Values (28-Mar-90 RAP)

- Radionuclide Library - Times $<100$ years (23-July-93 PDR)

- Pacific Northwest National Laboratory Food Transfer Factor Library (by Z, with Fr\&Os 7/19/93 PDR)

- External Dose Factors for GENII in person Sv/yr per Bq/x (8-May-90 RAP)

- Worst-Case Solubilities, Yearly Dose Increments (23-Jul-93 PDR).

There are two known errors in these files. First, the dose factors for ${ }^{110 \mathrm{~m}} \mathrm{Ag}$ are a factor of three too large because an incorrect branching ratio was used. Second, the food transfer factors are of uncertain origin due to inadequate documentation. Nevertheless, this code and libraries are currently preferred for Hanford Site modeling. below:

Specific modeling inputs for 24 hour ingestion dose calculations using GENII are listed

- Direct dose equivalent from the plume (i.e., inhalation and external dose from submersion) is not considered. Both doses were computed separately using dose factors from the U.S. Environmental Protection Agency listed in Tables 3-1 and 3-2. The external dose from air submersion dose is orders of magnitude smaller than the inhalation dose (Table 3-3).

- Resuspension of contamination deposited on the ground is estimated using the Anspaugh model found in GENII. Since GENII spreads the deposited activity to a depth of $15 \mathrm{~cm}$, this was also used as the depth of material resuspended so that all the deposited material participates. The first day's dose is approximated as the total in 1 year divided by 365 days.

- External exposure from material deposited on the ground is for 1 day. The exposure time input to GENII is 8766 hours, and the annual dose is divided by 365 days.

- The four vegetable pathways in GENII are (1) leafy vegetables, (2) other vegetables, (3) fruit, and (4) grain. Leafy vegetables are consumed directly from the garden, with 
little or no washing. Other vegetables (e.g., beans, peas, corn) and fruit are assumed to be harvested and a portion consumed the day of the accident. Since these crops are normally not ready for harvest on the same day, the resulting 24-hour dose is overestimated. In addition, since the produce is grown and consumed for only a portion of the year, the annual dose was divided by 180 days rather than 365 days to arrive at the 24-hour dose. Dose from grains is not included because the delay between harvest and consumption normally exceeds 1 day. It is assumed that people are successfully warned not to consume grain after the first day.

- The only animal pathway of concern is milk. The poultry and egg pathways rely on contamination of the grain the poultry eats. These products will not be contaminated the first day. The beef cow may graze on contaminated pasture prior to slaughter, but it will be assumed that the owners are warned and do not consume the meat. The milk cow grazes and is milked before the owners are warned not to drink the milk. Since equilibrium assumptions are made to estimate the milk concentration, the dose from contaminated milk is overestimated. Since milk is consumed daily throughout the year, the first day's dose is the total annual dose divided by 365 days.

The activity input to the GENII software is activity in $1 \mathrm{~g}$ of uranium with the spent fuel composition. This is the same source listed in Table 3-1. Two input files were used, one for animal products (milk) and one for vegetable produce. The GENII input files are listed in Appendix G, for reference. Table 3-4 shows the dose results by pathway. The dose factors shown on Table 3-4 are multiplied by the mass airborne and the air transport factor to arrive at the dose equivalent to a particular receptor from a given accident. This only differs from the inhalation dose formula by the omission of a breathing rate.

From Table 3-4 the direct dose from the plume is more than $99 \%$ of the total dose. Thus the other pathways can be ignored as negligible. (For information, the GENII value for the plume dose factor turns out to be $1.2 \mathrm{~Sv} / \mathrm{s}$ per $\mathrm{g} \mathrm{U} / \mathrm{m}^{3}$, which agrees well with the calculated value.)

\subsubsection{External Pathway}

The external exposure pathways are the result of exposure to gamma and X-ray radiation. Downwind receptors receive external radiation exposure by submersion, groundshine, and direct exposure to exposed SNF. Submersion refers to the external dose received by a person located in the airborne radioactive plume during plume passage. Groundshine refers to the external dose received by a person standing on ground contaminated by radioactive materials deposited during passage of the airborne radioactive plume. As shown in Table 3-4, groundshine and submersion doses are much smaller than inhalation doses for the nuclides present in SNF. Therefore, the groundshine and submersion doses are not included in calculations of the unit dose. 
Table 3-4. Unit Dose Factor for 24-Hour Exposure to the Offsite Maximum Exposed Individual.

\begin{tabular}{|c|c|}
\hline $\begin{array}{l}\text { Direct dose from plume } \\
\text { (inhalation and submersion) }\end{array}$ & $\begin{array}{c}(4,380 \mathrm{~Sv} / \mathrm{g} \mathrm{U})\left(2.64 \mathrm{E}-4 \mathrm{~m}^{3} / \mathrm{s}\right) \\
=1.16 \mathrm{~Sv} / \mathrm{s} \text { per g } \mathrm{U} / \mathrm{m}^{3}\end{array}$ \\
\hline Inhalation dose from resuspended material & $5.7 \mathrm{E}-4 \mathrm{~Sv} / \mathrm{s}$ per $\mathrm{g} \mathrm{U} / \mathrm{m}^{3}$ \\
\hline External dose from surface contamination & $3.8 \mathrm{E}-6 \mathrm{~Sv} / \mathrm{s}$ per $g \mathrm{U} / \mathrm{m}^{3}$ \\
\hline Ingestion dose from milk & $5.6 \mathrm{E}-4 \mathrm{~Sv} / \mathrm{s}$ per $\mathrm{g} \mathrm{U} / \mathrm{m}^{3}$ \\
\hline Ingestion dose from vegetable products & $6.9 \mathrm{E}-3 \mathrm{~Sv} / \mathrm{s}$ per $g \mathrm{U} / \mathrm{m}^{3}$ \\
\hline Total dose factor & $1.17 \mathrm{~Sv} / \mathrm{s}$ per $\mathrm{g} \mathrm{U} / \mathrm{m}^{3}$ \\
\hline
\end{tabular}

The direct dose factor was computed using U.S. Environmental Protection Agency inhalation dose factors and the daily average breathing rate. The other dose factors were computed using GENII Version 1.485 (PNL-6584). To compute the dose to the Site boundary farmer, multiply the total dose factor by the air transport factor and the mass released into the air as respirable particles.

The only other exposure pathway is direct exposure from the SNF itself. Because the nearest downwind receptor is $100 \mathrm{~m}$ from the scene of the accident, direct exposure to penetrating radiation emitted by the SNF is negligible due to the inverse square law reducing the dose rate. Note that $100 \mathrm{~m}$ of air does not present enough mass $\left(0.12 \mathrm{~g} / \mathrm{cm}^{2}\right)$ to have a shielding effect. Dose rates near any exposed SNF would be very high and create a worker safety issue.

\subsection{DOSE CALCULATION METHODS}

The process of estimating consequences from postulated emissions due to an accident at SNF Project facilities requires calculation of inhalation dose to worst-case receptors downwind and comparison of that dose with the risk evaluation guides (Sellers 1997). Calculating the dose begins with an estimation of the quantity of SNF that is released to the environment as respirable particles. This quantity is then multiplied by the appropriate air transport factor and unit dose to arrive at the receptor dose. The formula below summarizes the method for calculating this.

$$
\mathrm{M}=(\mathrm{MAR})(\mathrm{ARF})(\mathrm{RF})(\mathrm{LPF})
$$

where

$\mathrm{M}=$ mass released into the air as respirable particles, $\mathrm{g}$

MAR = material at risk: quantity of SNF that is involved in the postulated accident, $g$ 
$\mathrm{ARF}=$ airborne release fraction: fraction of the MAR that becomes airborne when some kind of stress (e.g., thermal, explosive) is applied to the MAR during a postulated accident

$\mathrm{RF}=$ respirable fraction: fraction of the airborne materials that can be transported through air and inhaled into the human respiratory system, normally unit density spheres $10 \mu \mathrm{m}$ or less in diameter (or their aerodynamic equivalent)

$\mathrm{LPF}=$ leak path factor: fraction of the airborne material that is transported through some confinement deposition or filtration processes.

For many accident scenarios (particularly those involving releases through high-efficiency particulate air [HEPA] filters), the respirable fraction is 1 , which means the total airborne release quantity is assumed to be equal to the respirable airborne release quantity. Once again, this depends on the type of stress applied to the material at risk during the accident scenario. The development of airborne release fractions and subsequent doses to downwind receptors should strive for realistic levels of conservatism. Bounding calculations usually assume the respirable fraction is 1 , unless credible experimental data is available.

Leak path factors are normally 1 for unmitigated dose calculations. The typical mitigating feature that affects leak path factor is HEPA filtration prior to release into the environment. Individual HEPA filter efficiency is greater than $99.97 \%$ for particles the filter is least efficient at removing. For accident mitigation calculations, reducing the environmental release by a factor of 1,000 (i.e., assume $99.90 \%$ efficiency) is adequate, unless the accident may damage the HEPA filter.

It is important to recognize that while the inhalation dose is a function of the quantity of respirable radioactive contaminants present at the receptor, the dose from other pathways (e.g., submersion, ingestion) is a function of the total quantity of radioactive contaminants present at the receptor. Because the inhalation dose is orders of magnitude greater than the dose from other pathways, this distinction normally is not considered. Only the respirable portion of the release is used in the dose calculations.

Because gases (e.g., tritium, krypton) and volatile solids (e.g., iodine) are in the fuel matrix, some accidents could liberate these materials more readily than others. If the release is filtered, the particulate material is reduced while these gases and volatile elements pass through unimpaired. The end result could be that the downwind consequences must be determined using a nuclide mixture that differs significantly from the original spent fuel. In such a case, a new value for unit dose is warranted.

In summary, the radiological dose calculations addressed in this report include only the inhalation pathway for all accident scenarios. These doses should be computed using the steps shown below. 
1. Determine the accident frequency range for the event.

2. Determine the quantity of radioactive material released into the air as respirable particles. It is also important to estimate the time required to release this material. The shorter the release duration, the larger the dose results to the downwind receptors.

3. Multiply the mass released by the air transport factor, the breathing rate, and the unit dose for each receptor of interest.

4. Compare the receptor doses with the risk evaluation guidelines. Doses which exceed the guidelines require controls of some type.

To illustrate the method, the doses from a 1-gram release of SNF as respirable particles is shown in Table 3-5. The table shows that the release duration has a significant effect on the estimated dose. Values in Table 3-5 were computed from the unit dose (Table 3-1), the appropriate breathing rate, and the ground-level air transport factors (Table 2-4).

The significance of the doses in Table 3-5 is found by comparison with the risk evaluation guidelines (Sellers 1997). Since the shortest release duration gives the largest doses, it will be closest to the risk guidelines. One way to make the comparison is to compute ratios of the above doses to the risk guidelines. For general evaluation purposes, it is useful to know the smallest release needed to produce downwind doses that exceed the risk evaluation guidelines. From such a table one can quickly determine which receptors are closest to their limits. In addition, one can avoid unnecessary detail in the accident analysis by knowing the bounding release amounts. Table 3-6 shows the number of grams that would have to be released to reach the risk guidelines. At all SNF facilities, the onsite receptor is closest to the risk guideline or first to exceed it. 
Table 3-5. Effective Dose Equivalent in Sieverts from One-Gram Uranium Fuel Releases.

\begin{tabular}{|c|c|c|c|c|}
\hline \multirow{2}{*}{ Receptor type } & \multicolumn{4}{|c|}{ Release duration category } \\
\hline & $<1 \mathrm{hr}$ & $1 \mathrm{hr}$ to $2 \mathrm{hr}$ & $12 \mathrm{hr}$ & $24 \mathrm{hr}$ \\
\hline \multicolumn{5}{|c|}{ K West Reactor and adjacent buildings } \\
\hline Onsite worker & $1.07 \mathrm{E}-01$ & $1.81 \mathrm{E}-02$ & $9.16 \mathrm{E}-03$ & $4.58 \mathrm{E}-03$ \\
\hline Columbia River & $5.18 \mathrm{E}-03$ & 9.00 E-04 & $4.23 \mathrm{E}-04$ & $2.11 \mathrm{E}-04$ \\
\hline 100 Area Fire Station & $2.33 \mathrm{E}-04$ & 1.14 E-04 & 3.99 E-05 & 1.99 E-05 \\
\hline Hanford Site boundary & $6.55 \mathrm{E}-05$ & 4.55 E-05 & $1.27 \mathrm{E}-05$ & $7.52 \mathrm{E}-06$ \\
\hline \multicolumn{5}{|c|}{ Cold Vacuum Drying Facility } \\
\hline Onsite worker & $1.07 \mathrm{E}-01$ & $1.81 \mathrm{E}-02$ & $9.16 \mathrm{E}-03$ & $4.58 \mathrm{E}-03$ \\
\hline Columbia River & $3.56 \mathrm{E}-03$ & $6.20 \mathrm{E}-04$ & $2.90 \mathrm{E}-04$ & $1.45 \mathrm{E}-04$ \\
\hline 100 Area Fire Station & $2.33 \mathrm{E}-04$ & $1.14 \mathrm{E}-04$ & 3.99 E-05 & $1.99 \mathrm{E}-05$ \\
\hline Hanford Site boundary & $6.54 \mathrm{E}-05$ & $4.54 \mathrm{E}-05$ & 1.47 E-05 & $7.51 \mathrm{E}-06$ \\
\hline \multicolumn{5}{|c|}{ Canister Storage Building } \\
\hline Onsite worker & $4.98 \mathrm{E}-02$ & $1.65 \mathrm{E}-02$ & 8.09 E-03 & $4.04 \mathrm{E}-03$ \\
\hline Highway 240 & $3.44 \mathrm{E}-05$ & $2.64 \mathrm{E}-05$ & 9.09 E-06 & $4.54 \mathrm{E}-06$ \\
\hline Hanford Site boundary & $1.90 \mathrm{E}-05$ & $1.59 \mathrm{E}-05$ & $5.61 \mathrm{E}-06$ & $2.97 \mathrm{E}-06$ \\
\hline
\end{tabular}

Notes: Release quantity is $1 \mathrm{~g}$ of SNF at ground level. Air transport factors are from Table 2-4. The light activity breathing rate $\left(3.33 \times 10^{-4} \mathrm{~m}^{3} / \mathrm{s}\right)$ is used everywhere except for 24 -hour releases where the average breathing rate for the Hanford Site boundary receptor is $2.64 \times 10^{-4} \mathrm{~m}^{3} / \mathrm{s}$ corresponding to 16 hours awake and 8 hours asleep. The unit dose is from Table 3-1. 
Table 3-6. Minimum Releases to Reach the Radiological Risk Guidelines.

\begin{tabular}{|c|c|c|c|c|}
\hline \multirow{2}{*}{ Receptor type } & \multirow{2}{*}{$\begin{array}{l}\text { Receptor } \\
\text { location }\end{array}$} & \multicolumn{3}{|c|}{$\begin{array}{l}\text { Grams of fuel to be released to reach risk } \\
\text { guidelines }\end{array}$} \\
\hline & & Anticipated & Unlikely & $\begin{array}{l}\text { Extremely } \\
\text { unlikely }\end{array}$ \\
\hline \multicolumn{5}{|c|}{ K West Reactor and Adjacent Buildings } \\
\hline Onsite worker & $100 \mathrm{~m} \mathrm{E}$ & $9.36 \mathrm{E}-02$ & $9.36 \mathrm{E}-01$ & $2.34 \mathrm{E}+00$ \\
\hline Columbia River & $520 \mathrm{~m} \mathrm{~W}$ & $9.65 \mathrm{E}-01$ & $9.65 \mathrm{E}+00$ & $9.65 \mathrm{E}+00$ \\
\hline 100 Area Fire Station & $3,750 \mathrm{~m} \mathrm{ESE}$ & $4.28 \mathrm{E}+01$ & $4.28 \mathrm{E}+02$ & $1.07 \mathrm{E}+03$ \\
\hline Hanford Site boundary & $10,070 \mathrm{~m} \mathrm{~W}$ & $7.63 \mathrm{E}+01$ & $7.63 \mathrm{E}+02$ & $7.63 \mathrm{E}+02$ \\
\hline \multicolumn{5}{|c|}{ Cold Vacuum Drying Facility } \\
\hline Onsite worker & $100 \mathrm{~m} \mathrm{E}$ & $9.36 \mathrm{E}-02$ & $9.36 \mathrm{E}-01$ & $2.34 \mathrm{E}+00$ \\
\hline Columbia River & $650 \mathrm{~m} \mathrm{~W}$ & $1.40 \mathrm{E}+00$ & $1.40 \mathrm{E}+01$ & $1.40 \mathrm{E}+01$ \\
\hline 100 Area Fire Station & $3,750 \mathrm{~m} \mathrm{ESE}$ & $4.28 \mathrm{E}+01$ & $4.28 \mathrm{E}+02$ & $1.07 \mathrm{E}+03$ \\
\hline Hanford Site boundary & $10,090 \mathrm{~m} \mathrm{~W}$ & $7.65 \mathrm{E}+01$ & $7.65 \mathrm{E}+02$ & $7.65 \mathrm{E}+02$ \\
\hline \multicolumn{5}{|c|}{ Canister Storage Building } \\
\hline Onsite worker & $100 \mathrm{~m} \mathrm{E}$ & $2.01 \mathrm{E}-01$ & $2.01 \mathrm{E}+00$ & $5.02 \mathrm{E}+00$ \\
\hline Highway 240 & $9,280 \mathrm{~m} \mathrm{~W}$ & $1.45 \mathrm{E}+02$ & $1.45 \mathrm{E}+03$ & $1.45 \mathrm{E}+03$ \\
\hline Hanford Site boundary & $17,390 \mathrm{~m} \mathrm{E}$ & $2.64 \mathrm{E}+02$ & $2.64 \mathrm{E}+03$ & $2.64 \mathrm{E}+03$ \\
\hline
\end{tabular}

The assumed release is from ground level and has a duration less than 1 hour. 
HNF-SD-SNF-TI-059 REV 2

This page intentionally left blank. 
HNF-SD-SNF-TI-059 REV 2

\subsection{TOXICOLOGICAL CONSEQUENCE METHODOLOGY}

\subsection{SOURCE COMPOSITION}

Table 4-1 shows the fuel composition and the air concentration limits for each analyte. The fuel composition is taken from HNF-SD-SNF-TI-015. The value for cesium has been increased by a factor of 100 to correct an obvious error in the databook. The air concentration limits are from PEC-CAT-97-0044A, ERPGs and TEELs for Chemicals of Concern at SRS (Craig 1997). Conservative limits were chosen by assuming the compounds that could be formed during an explosion are present. The column labeled "Normalized" shows the grams of each element per gram of SNF. It was computed by dividing the values in the first column by the value for the total mass.

Other chemicals which are likely to be part of any release from the MCO are helium and hydrogen. The primary hazard from hydrogen is the explosive reaction with air. Both gases will displace air, and may present a suffocation hazard to personnel in the facility. However, at the downwind locations under consideration, these gases will have been diluted with air to the point that neither hazard is realistic. The hydrogen will be below the lower flammable limit, and enough oxygen is present in the mixture to sustain life.

Table 4-2 shows the ratios between mass per gram of fuel and the limiting air concentration for each element. The units for this table are $\mathrm{m}^{3} / \mathrm{g}$ SNF. Elements with no concentration limit have been omitted from the table. Only three elements cause $99.9 \%$ of the result. These are uranium, zirconium, and beryllium. Of these three, uranium contributes more than $97 \%$ of the total result. As long as the composition of the material released into the air does not differ significantly from the fuel itself, the toxicological effects are determined by one element, uranium. Uranium acts like many heavy metals to damage one or more internal organs of individuals exposed to high air concentrations. The toxicity depends on the solubility of the uranium, with more soluble compounds being a greater hazard because they are transferred from the respiratory tract into the blood more quickly.

Note that using the PEL-TWA for accidental releases is not strictly appropriate because the PEL-TWA is designed to control relatively long-term worker exposure rather than the short-term exposure to the public that would be expected for accident response. The lower of the ERPG-1 and the PEL-TWA should be used for the offsite exposure for high frequency events. Use of the limits that are at or below the ERPG-1 accident category provides an additional level of conservatism. However, only iodine falls into this category, so this refinement has no effect on the resulting composition-weighted risk guideline (CWRG).

Note that there are no concentration limits for long-lived alpha-emitting radionuclides (Am, $\mathrm{Cm}, \mathrm{Np}$, and $\mathrm{Pu}$ ). If it is assumed that these elements have biological effects similar to uranium, then the limits for uranium could be used as a first approximation. With this assumption, it can be seen that these heavy metals would add about $0.20 \%$ to the total. In other words, the omitted heavy metals are a negligible addition to the toxicological effects. 
Table 4-1. Composition of Spent Fuel and Air Concentration Limits. (2 sheets)

\begin{tabular}{|c|c|c|c|c|c|c|}
\hline \multirow{2}{*}{ Analyte } & \multirow{2}{*}{$\begin{array}{l}\text { Mass in } \\
\text { fuel, } \mathrm{kg}\end{array}$} & \multirow{2}{*}{ Normalized } & \multicolumn{4}{|c|}{ Air concentration limits, $\mathrm{mg} / \mathrm{m}^{3}$} \\
\hline & & & PEL-TWA & ERPG-1 & ERPG-2 & ERPG-3 \\
\hline $\mathrm{Al}$ & $1.70 \mathrm{E}+03$ & $8.10 \mathrm{E}-04$ & 10 & 15 & 15 & 25 \\
\hline Am & $1.09 \mathrm{E}+02$ & $5.19 \mathrm{E}-05$ & NA & NA & $\mathrm{NA}$ & $\mathrm{NA}$ \\
\hline B & $6.05 \mathrm{E}-01$ & $2.88 \mathrm{E}-07$ & 10 & 30 & 50 & 250 \\
\hline $\mathrm{Be}$ & $1.63 \mathrm{E}+02$ & 7.76 E-05 & 0.002 & 0.01 & 0.025 & 0.1 \\
\hline $\mathrm{C}$ & $1.20 \mathrm{E}+03$ & $5.71 \mathrm{E}-04$ & 39.9 & 228 & 399 & 570 \\
\hline $\mathrm{Cd}$ & $6.05 \mathrm{E}-01$ & $2.88 \mathrm{E}-07$ & 0.005 & 0.03 & 4 & 9 \\
\hline $\mathrm{Cm}$ & $1.78 \mathrm{E}-02$ & $8.48 \mathrm{E}-09$ & NA & NA & NA & NA \\
\hline $\mathrm{Co}$ & $1.54 \mathrm{E}+00$ & $7.33 \mathrm{E}-07$ & NA & NA & NA & $\mathrm{NA}$ \\
\hline $\mathrm{Cr}$ & $2.88 \mathrm{E}+02$ & 1.37 E-04 & 0.5 & 1.5 & 2.5 & 25 \\
\hline $\mathrm{Cs}$ & $4.65 \mathrm{E}+02$ & $2.21 \mathrm{E}-04$ & $\mathrm{NA}$ & $\mathrm{NA}$ & $\mathrm{NA}$ & NA \\
\hline $\mathrm{Cu}$ & $1.66 \mathrm{E}+02$ & 7.90 E-05 & 1 & 3 & 5 & 100 \\
\hline $\mathrm{Fe}$ & $9.41 \mathrm{E}+02$ & $4.48 \mathrm{E}-04$ & 10 & 15 & 25 & 2,500 \\
\hline $\mathrm{H}$ & $8.06 \mathrm{E}+00$ & 3.84 E-06 & NA & $\mathrm{NA}$ & $\mathrm{NA}$ & NA \\
\hline $\mathrm{Hf}$ & $3.02 \mathrm{E}+01$ & $1.44 \mathrm{E}-05$ & NA & NA & $\mathrm{NA}$ & $\mathrm{NA}$ \\
\hline I & $4.61 \mathrm{E}+01$ & $2.20 \mathrm{E}-05$ & 3.1 & 1.0 & 5.2 & 52 \\
\hline $\mathrm{Kr}$ & $7.71 \mathrm{E}+01$ & $3.67 \mathrm{E}-05$ & NA & NA & $\mathrm{NA}$ & $\mathrm{NA}$ \\
\hline $\mathrm{Mg}$ & $5.58 \mathrm{E}+01$ & $2.66 \mathrm{E}-05$ & 10 & 30 & 50 & 250 \\
\hline $\mathrm{Mn}$ & $6.03 \mathrm{E}+01$ & $2.87 \mathrm{E}-05$ & 0.2 & 3 & 5 & 500 \\
\hline Mo & $7.54 \mathrm{E}+00$ & $3.59 \mathrm{E}-06$ & $\mathrm{NA}$ & NA & NA & NA \\
\hline $\mathrm{N}$ & $1.70 \mathrm{E}+02$ & $8.10 \mathrm{E}-05$ & $\mathrm{NA}$ & NA & $\mathrm{NA}$ & $\mathrm{NA}$ \\
\hline $\mathrm{Na}$ & $3.02 \mathrm{E}+00$ & 1.44 E-06 & 2 & 2 & 40 & 100 \\
\hline $\mathrm{Ni}$ & $2.94 \mathrm{E}+02$ & 1.40 E-04 & 1 & 3 & 10 & 10 \\
\hline $\mathrm{Np}$ & $8.11 \mathrm{E}+01$ & $3.86 \mathrm{E}-05$ & $\mathrm{NA}$ & NA & NA & NA \\
\hline $\mathrm{O}$ & $6.53 \mathrm{E}+00$ & $3.11 \mathrm{E}-06$ & NA & NA & NA & $\mathrm{NA}$ \\
\hline $\mathrm{Pb}$ & $1.52 \mathrm{E}+01$ & 7.24 E-06 & 0.05 & 0.15 & 0.25 & 100 \\
\hline $\mathrm{Pd}$ & $1.33 \mathrm{E}+02$ & 6.33 E-05 & 10 & 30 & 50 & 250 \\
\hline
\end{tabular}


Table 4-1. Composition of Spent Fuel and Air Concentration Limits. (2 sheets)

\begin{tabular}{|l|c|c|c|c|c|c|}
\hline \multirow{2}{*}{ Analyte } & \multirow{2}{*}{$\begin{array}{c}\text { Mass in } \\
\text { fuel, kg }\end{array}$} & \multirow{2}{*}{ Normalized } & \multicolumn{4}{|c|}{ Air concentration limits, mg/m } \\
\cline { 5 - 7 } & & & PEL-TWA & ERPG-1 & ERPG-2 & ERPG-3 \\
\hline $\mathrm{Pm}$ & $5.00 \mathrm{E}-01$ & $2.38 \mathrm{E}-05$ & NA & NA & NA & NA \\
\hline $\mathrm{Pu}$ & $4.12 \mathrm{E}+03$ & $1.96 \mathrm{E}-03$ & NA & NA & NA & NA \\
\hline $\mathrm{Se}$ & $1.20 \mathrm{E}+01$ & $5.71 \mathrm{E}-06$ & 0.2 & 0.6 & 1 & 1 \\
\hline $\mathrm{Si}$ & $2.77 \mathrm{E}+02$ & $1.32 \mathrm{E}-04$ & 0.1 & 0.3 & 0.5 & 25 \\
\hline $\mathrm{Sm}$ & $6.54 \mathrm{E}+00$ & $3.11 \mathrm{E}-06$ & NA & NA & NA & NA \\
\hline $\mathrm{Sn}$ & $2.19 \mathrm{E}+03$ & $1.04 \mathrm{E}-03$ & 2 & 6 & 10 & 100 \\
\hline $\mathrm{Sr}$ & $1.52 \mathrm{E}+02$ & $3.52 \mathrm{E}-05$ & 10 & 30 & 50 & 500 \\
\hline $\mathrm{Tc}$ & $1.70 \mathrm{E}+02$ & $8.10 \mathrm{E}-05$ & NA & NA & NA & NA \\
\hline $\mathrm{Ti}$ & $7.54 \mathrm{E}+00$ & $3.59 \mathrm{E}-06$ & 10 & 30 & 50 & 250 \\
\hline $\mathrm{U}$ & $2.10 \mathrm{E}+06$ & $1.00 \mathrm{E}+00$ & 0.05 & 0.6 & 0.6 & 10 \\
\hline $\mathrm{V}$ & $7.54 \mathrm{E}+00$ & $3.59 \mathrm{E}-06$ & 0.05 & 0.15 & 7 & 35 \\
\hline $\mathrm{W}$ & $7.68 \mathrm{E}+00$ & $3.66 \mathrm{E}-06$ & NA & NA & NA & NA \\
\hline $\mathrm{Xe}$ & $1.04 \mathrm{E}+03$ & $4.95 \mathrm{E}-04$ & NA & NA & NA & NA \\
\hline $\mathrm{Zr}$ & $1.48 \mathrm{E}+05$ & $7.05 \mathrm{E}-02$ & 5 & 10 & 25 & 50 \\
\hline
\end{tabular}

Notes: Limits for aluminum (Al) are for aluminum oxide. Limits for carbon (C) are for carbon monoxide. Limits for chromium (Cr) are for chromium oxide. Limits for sodium $(\mathrm{Na})$ are for sodium hydroxide. Fuel masses are from HNF-SD-SNF-TI-015, 1998, Spent Nuclear Fuel Project Technical Databook, Rev. 6, Fluor Daniel Hanford, Incorporated, Richland, Washington.

$\mathrm{ERPG}=$ emergency response planning guidelines

NA $=$ not applicable

$\mathrm{PEL}=$ permissible exposure limit.

TWA $=$ time-weighted average. 
Table 4-2. Ratios of Normalized Fuel Composition to Risk Guidelines.

\begin{tabular}{|c|c|c|c|c|}
\hline Analyte & PEL-TWA & ERPG-1 & ERPG-2 & ERPG-3 \\
\hline $\mathrm{Al}$ & 8.10 E-02 & $5.40 \mathrm{E}-02$ & $5.40 \mathrm{E}-02$ & $3.24 \mathrm{E}-02$ \\
\hline $\mathrm{B}$ & $2.88 \mathrm{E}-05$ & $9.60 \mathrm{E}-06$ & $5.76 \mathrm{E}-06$ & $1.15 \mathrm{E}-06$ \\
\hline $\mathrm{Be}$ & $3.88 \mathrm{E}+01$ & $7.76 E+00$ & $3.10 \mathrm{E}+00$ & $7.76 \mathrm{E}-01$ \\
\hline $\mathrm{C}$ & $1.43 \mathrm{E}-02$ & $2.51 \mathrm{E}-03$ & $1.43 \mathrm{E}-03$ & $1.00 \mathrm{E}-03$ \\
\hline $\mathrm{Cd}$ & $5.76 \mathrm{E}-02$ & $9.60 \mathrm{E}-03$ & $7.20 \mathrm{E}-05$ & $3.20 \mathrm{E}-05$ \\
\hline $\mathrm{Cr}$ & 2.74 E-01 & $9.14 \mathrm{E}-02$ & $5.49 \mathrm{E}-02$ & $5.49 \mathrm{E}-03$ \\
\hline $\mathrm{Cu}$ & 7.90 E-02 & $2.63 \mathrm{E}-02$ & $1.58 \mathrm{E}-02$ & $7.90 \mathrm{E}-04$ \\
\hline $\mathrm{Fe}$ & $4.48 \mathrm{E}-02$ & $2.99 \mathrm{E}-02$ & $1.79 \mathrm{E}-02$ & $1.79 \mathrm{E}-04$ \\
\hline I & 7.06 E-03 & $2.12 \mathrm{E}-02$ & $4.23 \mathrm{E}-03$ & $4.23 \mathrm{E}-04$ \\
\hline $\mathrm{Mg}$ & $2.66 \mathrm{E}-03$ & $8.86 \mathrm{E}-04$ & $5.31 \mathrm{E}-04$ & $1.06 \mathrm{E}-04$ \\
\hline $\mathrm{Mn}$ & $1.44 \mathrm{E}-01$ & $9.57 \mathrm{E}-03$ & $5.74 \mathrm{E}-03$ & $5.74 \mathrm{E}-05$ \\
\hline $\mathrm{Na}$ & 7.19 E-04 & $7.19 \mathrm{E}-04$ & $3.60 \mathrm{E}-05$ & 1.44 E-05 \\
\hline $\mathrm{Ni}$ & $1.40 \mathrm{E}-01$ & 4.67 E-02 & 1.40 E-02 & $1.40 \mathrm{E}-02$ \\
\hline $\mathrm{Pb}$ & $1.45 \mathrm{E}-01$ & $4.83 \mathrm{E}-02$ & $2.90 \mathrm{E}-02$ & $7.24 \mathrm{E}-05$ \\
\hline $\mathrm{Pd}$ & $6.33 \mathrm{E}-03$ & $2.11 \mathrm{E}-03$ & $1.27 \mathrm{E}-03$ & $2.53 \mathrm{E}-04$ \\
\hline $\mathrm{Se}$ & $2.86 \mathrm{E}-02$ & 9.52 E-03 & $5.71 \mathrm{E}-03$ & $5.71 \mathrm{E}-03$ \\
\hline $\mathrm{Si}$ & $1.32 \mathrm{E}+00$ & 4.40 E-01 & $2.64 \mathrm{E}-01$ & $5.28 \mathrm{E}-03$ \\
\hline $\mathrm{Sn}$ & $5.21 \mathrm{E}-01$ & $1.74 \mathrm{E}-01$ & $1.04 \mathrm{E}-01$ & $1.04 \mathrm{E}-02$ \\
\hline $\mathrm{Sr}$ & $7.24 \mathrm{E}-03$ & $2.41 \mathrm{E}-03$ & $1.45 \mathrm{E}-03$ & 1.45 E-04 \\
\hline $\mathrm{Ti}$ & $3.59 \mathrm{E}-04$ & 1.20 E-04 & $7.18 \mathrm{E}-05$ & 1.44 E-05 \\
\hline $\mathrm{U}$ & $2.00 \mathrm{E}+04$ & $1.67 \mathrm{E}+03$ & $1.67 \mathrm{E}+03$ & $1.00 \mathrm{E}+02$ \\
\hline $\mathrm{V}$ & $7.18 \mathrm{E}-02$ & $2.39 \mathrm{E}-02$ & 5.13 E-04 & $1.03 \mathrm{E}-04$ \\
\hline $\mathrm{Zr}$ & $1.41 \mathrm{E}+01$ & $7.05 \mathrm{E}+00$ & $2.82 \mathrm{E}+00$ & $1.41 \mathrm{E}+00$ \\
\hline Total: & $2.01 \mathrm{E}+04$ & $1.68 \mathrm{E}+03$ & $1.67 \mathrm{E}+03$ & $1.02 \mathrm{E}+02$ \\
\hline \multicolumn{5}{|c|}{$\begin{array}{l}\text { Notes: Units are } \mathrm{m}^{3} / \mathrm{g} \mathrm{SNF} \text {, resulting from dividing the grams of each element per gram of uranium by the } \\
\text { concentration limit in } \mathrm{mg} / \mathrm{m}^{3} \text {. Elements without limits have been omitted from the table. } \\
\text { The fractions of the total for the three main contributors are shown below. }\end{array}$} \\
\hline $\mathrm{Be}$ & $0.19 \%$ & $0.46 \%$ & $0.19 \%$ & $0.76 \%$ \\
\hline$U$ & $99.72 \%$ & $99.06 \%$ & $99.61 \%$ & $97.79 \%$ \\
\hline $\mathrm{Zr}$ & $0.07 \%$ & $0.42 \%$ & $0.17 \%$ & $1.38 \%$ \\
\hline
\end{tabular}

ERPG = emergency response planning guidelines.

$\mathrm{PEL}=$ permissible exposure limit.

TWA $=$ time-weighted average. 
The totals for each concentration limit category can be used in the air transport calculations of air concentration directly. They are given the name "Composition-weighted Risk Guides", or CWRG for spent fuel. The inverse of these values is the weighted concentration guide for SNF. The totals are listed in Table 4-3 according to the risk category and receptor. The formula below summarizes the calculation of a value for CWRG.

$$
\mathrm{CWRG}=\sum_{\mathrm{K}}(\mathrm{Mk}) /(\mathrm{CGK})
$$

where

CWRG $=$ composition-weighted risk guide, $\mathrm{m}^{3} / \mathrm{g}$ of spent fuel

$M_{K}=$ mass of the Kth chemical per gram of SNF, $g$ of chemical/g of spent fuel (U)

$\mathrm{CG}_{\mathrm{K}}=$ concentration guide for the Kth chemical, $\mathrm{g}$ of chemical $/ \mathrm{m}^{3}$ of air.

Table 4-3. Composition-Weighted Risk Guidelines for Spent Fuel.

\begin{tabular}{|c|c|c|c|}
\hline \multirow{2}{*}{ Receptor type } & \multicolumn{3}{|c|}{ Accident frequency } \\
\cline { 2 - 4 } & $\begin{array}{c}\text { Anticipated } \\
>0.01 / \mathrm{yr}\end{array}$ & $\begin{array}{c}\text { Unlikely } \\
0.01 \text { to } 1 \mathrm{E}-04 / \mathrm{yr}\end{array}$ & Extremely unlikely \\
\hline Onsite & $1,680 \mathrm{~m}^{3} / \mathrm{g}$ & $1,670 \mathrm{~m}^{3} / \mathrm{g}$ & $102 \mathrm{~m}^{3} / \mathrm{g}$ \\
\hline Offsite & $20,100 \mathrm{~m}^{3} / \mathrm{g}$ & $1,680 \mathrm{~m}^{3} / \mathrm{g}$ & $1,670 \mathrm{~m}^{3} / \mathrm{g}$ \\
\hline
\end{tabular}

Values are computed as the sum of the ratios of normalized chemical masses per gram of fuel divided by the concentration guidelines.

The composition-weighted concentration guide for SNF is the inverse of the CWRG computed in Table 4-3. These concentration guides are shown in Table 4-4. The units were changed from $\mathrm{g} / \mathrm{m}^{3}$ to $\mathrm{mg} / \mathrm{m}^{3}$. The values shown are essentially the concentration guidelines for uranium.

Table 4-4. Composition-Weighted Air Concentration Guidelines for Spent Fuel.

\begin{tabular}{|c|c|c|c|}
\hline \multirow{2}{*}{ Receptor type } & \multicolumn{3}{|c|}{ Accident frequency } \\
\cline { 2 - 4 } & $\begin{array}{c}\text { Anticipated } \\
>0.01 / \mathrm{yr}\end{array}$ & $\begin{array}{c}\text { Unlikely } \\
\text { to } 1 \text { E-04/yr }\end{array}$ & Extremely unlikely \\
\hline Onsite & $0.60 \mathrm{mg} / \mathrm{m}^{3}$ & $0.60 \mathrm{mg} / \mathrm{m}^{3}$ & $9.8 \mathrm{mg} / \mathrm{m}^{3}$ \\
\hline Offsite & $0.05 \mathrm{mg} / \mathrm{m}^{3}$ & $0.60 \mathrm{mg} / \mathrm{m}^{3}$ & $0.60 \mathrm{mg} / \mathrm{m}^{3}$ \\
\hline
\end{tabular}

Table 4-3.

Values are computed as $1,000 \mathrm{mg} / \mathrm{g}$ divided by the composition-weighted risk guideline values in 


\subsection{TOXICOLOGICAL EXPOSURE PATHWAYS}

Toxicants enter the bodies of people downwind by being inhaled, ingested or absorbed through the skin. Another route of entry is injection through cuts in the skin. This last one will not be considered, because it involves additional accidents downwind besides the SNF Project accident. After the toxicant enters the body it moves into the bloodstream and may cause some damage to a target organ. Eventually it is eliminated from the body. For a class of chemicals known as corrosives, the biological damage can occur without entering the bloodstream. Corrosive chemicals damage whatever tissue they are in contact with. They cause damage to organs such as the eyes, skin, or lungs, and usually exhibit a rapid effect.

The major toxicological exposure pathway for SNF accidents is inhalation of airborne particulate matter. Although a few compounds may be released as gases during accidents, the important chemicals are not gases. Helium and hydrogen are not toxic at the concentrations that would reach the downwind receptors. Particulate matter transported to the maximum onsite and/or offsite individual is assumed to be respirable. Larger particles would be removed by surface deposition mechanisms.

Other potential internal exposure pathways are absorption through the skin and ingestion of contaminated material. Absorption through the skin occurs primarily through physical contact between skin and the chemical, such as handling objects that have been contaminated by the passing plume. This pathway leads to smaller exposures than inhalation during plume passage. Ingestion of chemicals could occur from consuming crops or animals that have been exposed to the chemicals, consuming contaminated water, or ingestion of trace amounts of contaminated soil. Potential chemical exposures from the ingestion pathway are not included because federal and state programs are in place to prevent ingestion of contaminated food and water (DOE-0223, WSDOH 1993, WSDOA 1994, EPA 1992).

In evaluating the toxicological effects of accidental releases of particulate matter from SNF Project facilities the major contributors are three metals (uranium, beryllium, and zirconium). Conditions that result in concentrations of particulate matter high enough to interfere with breathing must be considered separately. Given the nature of the spent fuel particulate matter (uranium, zirconium, and oxides of both), there are no corrosive chemicals.

\subsection{TOXICOLOGICAL DOSE CALCULATION METHODS}

For toxic chemicals the accumulated dose is not computed. Rather, the air concentration is determined and compared with guidelines. Health effects from exposure to contaminated air depend on the chemical, the air concentration, and the exposure time. For corrosive chemicals the air concentration alone determines the amount of damage. Noncorrosive chemicals are carcinogens or have toxic effects based on the amount accumulated in the body. For noncorrosive chemicals the health effects depend on exposure time.

For accidents with release durations less than the transition times shown on Table 2-6, the puff model is appropriate for calculating air concentrations. The peak air concentration is calculated using the following equation: 


$$
\mathrm{C}_{\text {puff }}=(\mathrm{M})(\chi / \mathrm{Q})
$$

where

$$
\begin{aligned}
\mathrm{C}_{\text {puff }} & =\text { peak concentration at a downwind receptor location, } \mathrm{g} / \mathrm{m}^{3} \\
\mathrm{M} & =\text { mass of the toxic chemical released, } \mathrm{g} \\
\chi / \mathrm{Q} & =\text { puff release air transport factor, per } \mathrm{m}^{3} \text { (Table 2-6). }
\end{aligned}
$$

For accidents with release durations greater than the transition times shown on Table 2-6, the plume model is appropriate for calculating air concentrations. The average air concentration during plume passage is calculated using the following equation:

$$
\mathrm{C}_{\text {plume }}=(\mathrm{M})\left(\chi / \mathrm{Q}^{\prime}\right) / \mathrm{T}_{\text {rel }}
$$

where

$$
\begin{aligned}
\mathrm{C}_{\text {plume }} & =\text { average plume concentration at a downwind receptor location, } \mathrm{g} / \mathrm{m}^{3} \\
\mathrm{M} & =\text { mass of the toxic chemical released, } \mathrm{g} \\
\chi / \mathrm{Q}^{\prime} & \left.=\text { continuous release air transport factor, } \mathrm{s} / \mathrm{m}^{3} \text { (Tables } 2-4 \text { and } 2-5\right) \\
\mathrm{T}_{\mathrm{rel}} & =\text { release duration, } \mathrm{s} .
\end{aligned}
$$

For short release durations, the air concentrations can become quite large for brief periods. Because chemical injury takes a finite amount of time to occur in biological materials, a very high exposure for only a few seconds has a lower injury potential than a much lower exposure over a longer period of time. To accommodate this effect in a conservative way, the concept of an averaging period has been developed. One calculates the average concentration during some minimum period and compares this concentration with the concentration guideline. The averaging time used in the present calculations is 15 minutes, based on the following guidance from WSRC-MS-92-206, Toxic Chemical Hazard Classification and Risk Acceptance Guidelines for Use in DOE Facilities (Craig 1995):

4.2 Exposure time: Concentrations for comparison with the guidelines must be calculated as the peak 15-minute average concentrations, which are then compared with the guideline concentration limits. This is applicable for all chemicals for which the toxic effect is immediate (i.e., concentration-dependent). If it is known that the toxic effects of a chemical are not concentration-dependent, but depend on the total quantity of chemical taken up by the body (i.e., dose-dependent), then the peak 1-hour concentration may be used. Concentration dependent chemicals are defined as fast-acting chemicals whose toxic effects are immediate, and correlate more closely to concentration than dose. Included in this category are sensory irritants and chemicals which are corrosive or vesicant in their action. Any chemical which has 
been assigned an OSHA [Occupational Safety and Health Administration] PEL-STEL or PEL-C, or an ACGIH [American Conference of Governmental Industrial Hygienists] TLV-STEL or TLV-C value must be considered concentration-dependent. In contrast, the effects of dose-dependent chemicals are a function of both concentration and duration of exposure. However, a chemical may elicit concentration-dependent effects at high levels and dose-dependent effects at lower concentrations.

Since the exposure averaging time (15 minutes or 900 seconds) is greater than all the transition times shown on Table 2-6, puff releases are eliminated from further consideration. Air concentrations from accidents with release durations less than 15 minutes are calculated using the plume equation with the release time set to 900 seconds. This is summarized in the modified equation below.

$$
\mathrm{C}_{\mathrm{ave}}=(\mathrm{M})\left(\chi / \mathrm{Q}^{\prime}\right) / \max \left(\mathrm{T}_{\mathrm{rcl}}, \mathrm{T}_{\mathrm{ave}}\right)
$$

where

$$
\begin{aligned}
\mathrm{C}_{\mathrm{ave}} & =\text { average concentration of a chemical at a downwind receptor location, } \mathrm{g} / \mathrm{m}^{3} \\
\mathrm{M} & =\text { mass of the toxic chemical released, } \mathrm{g} \\
\chi / \mathrm{Q}^{\prime} & \left.=\text { continuous release air transport factor, } \mathrm{s} / \mathrm{m}^{3} \text { (Tables } 2-4 \text { and } 2-5\right) \\
\mathrm{T}_{\mathrm{rel}} & =\text { release duration, } \mathrm{s} \\
\mathrm{T}_{\mathrm{ave}} & =\text { exposure averaging period, } 900 \mathrm{~s} .
\end{aligned}
$$

When more than one chemical is released, a sum-of-fractions method is used to evaluate concentrations against the risk guidelines. The sum-of-fractions method was adapted from American Conference of Governmental Industrial Hygienists and Occupational Safety and Health Administration methods for adding combined exposures to compounds with similar health effects:

$$
\mathrm{SOF}=\sum_{\mathrm{K}}(\mathrm{CK}) /\left(\mathrm{CGK}_{\mathrm{K}}\right)
$$

where

$$
\begin{aligned}
\mathrm{SOF} & =\text { sum-of-fractions for a mixture of chemicals in air } \\
\mathrm{C}_{\mathrm{K}} & =\text { calculated average air concentration for the Kth chemical, } \mathrm{g} / \mathrm{m}^{3} \\
\mathrm{CG}_{\mathrm{K}} & =\text { concentration guide for the Kth chemical, g of chemical } / \mathrm{m}^{3} \text { of air. }
\end{aligned}
$$

When the formula for average air concentration at the downwind receptor location is substituted into the sum-of-fractions formula, the result is shown below. The sum over ratios of mass fraction divided by concentration guideline has been written as CWRG. Equivalently, the CWRG could be replaced with the inverse of the composition-weighted air concentration guideline (Table 4-4). 


$$
\begin{gathered}
\mathrm{SOF}=\sum_{\mathrm{K}}(\mathrm{M})\left(\mathrm{MK}_{\mathrm{K}}\right)\left(\chi / \mathrm{Q}^{\prime}\right) / \max \left(\mathrm{T}_{\mathrm{rel}}, \mathrm{T}_{\mathrm{ave}}\right) /(\mathrm{CGK}) \\
\mathrm{SOF}=(\mathrm{M})(\mathrm{CWRG})\left(\chi / \mathrm{Q}^{\prime}\right) / \max \left(\mathrm{T}_{\mathrm{rel}}, \mathrm{T}_{\mathrm{ave}}\right)
\end{gathered}
$$

where

$\mathrm{SOF}=$ sum-of-fractions for a mixture of chemicals (e.g., SNF) suspended in air

$\mathrm{M}=$ total mass of SNF (a mixture of chemicals) released into the air as respirable particles, $\mathrm{g}$

$M_{K}=$ mass of the Kth chemical per gram of SNF, $g$ of chemical/g of spent fuel (U). This can be estimated for a given accident using the method described in.Section 3.3.

$\chi / Q^{\prime}=$ continuous release air transport factor, $\mathrm{s} / \mathrm{m}^{3}$

$\mathrm{T}_{\mathrm{rel}}=$ release duration, $\mathrm{s}$

$\mathrm{T}_{\mathrm{ave}}=$ exposure averaging period, $900 \mathrm{~s}$.

$\mathrm{CWRG}=$ composition-weighted risk guide, $\mathrm{m}^{3} / \mathrm{g}$ of spent fuel (U)

$\mathrm{CG}_{\mathrm{K}}=$ concentration guide for the Kth chemical, $\mathrm{g}$ of chemical $/ \mathrm{m}^{3}$ of air.

Note that one more refinement should be considered for long duration releases. In the event that the release duration is greater than the time characteristic of the risk evaluation guideline ( 1 hour or 8 hours), then the concentration guideline should be reduced. This approach is based on the observation that the total amount inhaled is related to the health effects on individuals downwind. Mathematically, one changes the definition of the concentration guideline to that shown below.

$$
\begin{aligned}
& \text { If } \mathrm{T}_{\mathrm{rcl}}<\mathrm{T}_{\text {guide }} \text {, then } \mathrm{CG}_{\mathrm{K}}^{\prime}=\mathrm{CG}_{\mathrm{K}} \\
& \text { If } \mathrm{T}_{\text {rel }}>\mathrm{T}_{\text {guide }} \text { then } \mathrm{CG}_{\mathrm{K}}^{\prime}=\left(\mathrm{CG}_{\mathrm{K}}\right)\left(\mathrm{T}_{\text {guide }}\right) /\left(\mathrm{T}_{\mathrm{rcl}}\right) \\
& \text { or, } \mathrm{CG}_{\mathrm{K}}^{\prime}=\left(\mathrm{CG}_{\mathrm{K}}\right) \cdot \min \left[1,\left(\mathrm{~T}_{\text {guidc }}\right) /\left(\mathrm{T}_{\mathrm{rcl}}\right)\right]
\end{aligned}
$$

With this revised definition of CWRG for long duration releases, it is necessary to revise the formula for sum-of-fractions. The formula below shows the results of the revision. Note that the main effect of the revision is to limit the release duration $\left(\mathrm{T}_{\mathrm{rel}}\right)$ to the time inherent in the risk evaluation guideline $\left(\mathrm{T}_{\text {guide }}\right)$. For release durations less than $\mathrm{T}_{\mathrm{avc}}$, the formula uses the minimum averaging time. For release durations longer than $T_{\text {ave }}$ but shorter than $T_{\text {guide, }}$, the formula uses the release duration. For release durations longer than $\mathrm{T}_{\text {guide }}$, the formula uses the guideline time.

$$
\mathrm{SOF}=(\mathrm{M})(\mathrm{CWRG})\left(\chi / \mathrm{Q}^{\prime}\right) / \min \left[\mathrm{T}_{\text {guide }}, \max \left(\mathrm{T}_{\mathrm{rcl}}, \mathrm{T}_{\mathrm{avc}}\right)\right]
$$


This equation should be used when it is necessary to determine the toxicological consequences of accidental releases from SNF Project facilities. Sum-of-fractions that are less than one indicate that risk evaluation guidelines are met. Sum-of-fractions that are greater than one indicate that risk evaluation guidelines are exceeded and some type of control must be added.

Note that the released material is assumed to have the same composition as spent fuel. If an accident results in additional chemicals besides the materials in SNF, then a new CWRG must be generated.

The toxicological calculations addressed in this report use the above equation. The calculations for toxic chemical releases should be carried out using the steps shown below.

1. Determine the accident frequency range for the event.

2. Determine the quantity of material released into the air as respirable particles. It is also important to estimate the time required to release this material. If the duration exceeds 15 minutes, then the 15 -minute period during the release that contains the greatest amount released must be used in the calculation of the sum-of-fractions.

3. Determine the sum-of-fractions by multiplying the mass released by the air transport factor and the CWRG, and dividing by the larger of the release duration or 900 seconds.

To illustrate the method, the sum-of-fractions following a 1-gram release of SNF as respirable particles is shown in Table 4-5. Values in Table 4-5 were computed from the CWRG (Table 4-3), the ground-level air transport factors (Table 2-4), and an assumed release duration of 15 minutes.

For general purpose evaluation of accidents, it is useful to know the smallest release needed to exceed the risk evaluation guidelines. From such a table one can quickly determine which receptors are closest to their limits. In addition, one can avoid unnecessary detail in the accident analysis by knowing the bounding release amounts. Table 4-6 shows the number of grams that would have to be released to reach the risk guidelines. At all SNF Project facilities, the onsite receptor is closest to the risk guideline or first to exceed it. 
Table 4-5. Maximum Sum-of-Fractions for a One-Gram Uranium Fuel Release at Ground Level.

\begin{tabular}{|l|c|c|c|c|}
\hline \multirow{2}{*}{ Receptor type } & \multirow{2}{*}{$\begin{array}{c}\text { Receptor } \\
\text { location }\end{array}$} & Anticipated & Unlikely & $\begin{array}{c}\text { Extremely } \\
\text { unlikely }\end{array}$ \\
\cline { 3 - 5 } & & & \multicolumn{3}{|c|}{ Accident frequency } \\
\hline K West Reactor and adjacent buildings \\
\hline Onsite worker & $100 \mathrm{~m} \mathrm{E}$ & $1.37 \mathrm{E}-01$ & $1.36 \mathrm{E}-01$ & $8.32 \mathrm{E}-03$ \\
\hline Columbia River & $520 \mathrm{~m} \mathrm{~W}$ & $7.91 \mathrm{E}-02$ & $6.64 \mathrm{E}-03$ & $6.60 \mathrm{E}-03$ \\
\hline 100 Area Fire Station & $3,750 \mathrm{~m} \mathrm{ESE}$ & $2.99 \mathrm{E}-04$ & $2.97 \mathrm{E}-04$ & $1.82 \mathrm{E}-05$ \\
\hline Hanford Site boundary & $10,070 \mathrm{~m} \mathrm{~W}$ & $1.00 \mathrm{E}-03$ & $8.39 \mathrm{E}-05$ & $8.35 \mathrm{E}-05$ \\
\hline Cold Vacuum Drying Facility & $100 \mathrm{~m} \mathrm{E}$ & $1.37 \mathrm{E}-01$ & $1.36 \mathrm{E}-01$ & $8.32 \mathrm{E}-03$ \\
\hline Onsite worker & $650 \mathrm{~m} \mathrm{~W}$ & $5.44 \mathrm{E}-02$ & $4.56 \mathrm{E}-03$ & $4.54 \mathrm{E}-03$ \\
\hline Columbia River & $3,750 \mathrm{~m} \mathrm{ESE}$ & $2.99 \mathrm{E}-04$ & $2.97 \mathrm{E}-04$ & $1.82 \mathrm{E}-05$ \\
\hline 100 Area Fire Station & $10,090 \mathrm{~m} \mathrm{~W}$ & $9.98 \mathrm{E}-04$ & $8.37 \mathrm{E}-05$ & $8.33 \mathrm{E}-05$ \\
\hline Hanford Site boundary & & & & \\
\hline Canister Storage Building & $100 \mathrm{~m} \mathrm{E}$ & $6.37 \mathrm{E}-02$ & $6.34 \mathrm{E}-02$ & $3.87 \mathrm{E}-03$ \\
\hline Onsite worker & $9,280 \mathrm{~m} \mathrm{~W}$ & $5.26 \mathrm{E}-04$ & $4.41 \mathrm{E}-05$ & $4.39 \mathrm{E}-05$ \\
\hline Highway 240 & $17,390 \mathrm{~m} \mathrm{E}$ & $2.90 \mathrm{E}-04$ & $2.43 \mathrm{E}-05$ & $2.42 \mathrm{E}-05$ \\
\hline Hanford Site boundary
\end{tabular}

Since the exposure averaging time is 15 minutes, the release duration is chosen to be 15 minutes to maximize the Sum-of-fractions. 
Table 4-6. Minimum Releases to Reach the Toxicological Risk Guidelines.

\begin{tabular}{|l|c|c|c|c|}
\hline \multirow{2}{*}{$\begin{array}{l}\text { Receptor type } \\
\text { Receptor } \\
\text { location }\end{array}$} & Anticipated & Unlikely & $\begin{array}{c}\text { Extremely } \\
\text { unlikely }\end{array}$ \\
\cline { 3 - 5 } & K West Reactor and adjacent buildings \\
\hline Onsite worker & $100 \mathrm{~m} \mathrm{E}$ & $7.31 \mathrm{E}+00$ & $7.35 \mathrm{E}+00$ & $1.20 \mathrm{E}+02$ \\
\hline Columbia River & $520 \mathrm{~m} \mathrm{~W}$ & $1.26 \mathrm{E}+01$ & $1.51 \mathrm{E}+02$ & $1.52 \mathrm{E}+02$ \\
\hline 100 Area Fire Station & $3,750 \mathrm{~m} \mathrm{ESE}$ & $3.34 \mathrm{E}+03$ & $3.36 \mathrm{E}+03$ & $5.50 \mathrm{E}+04$ \\
\hline Hanford Site boundary & $10,070 \mathrm{~m} \mathrm{~W}$ & $9.99 \mathrm{E}+02$ & $1.19 \mathrm{E}+04$ & $1.20 \mathrm{E}+04$ \\
\hline \multicolumn{5}{|c|}{ Cold Vacuum Drying Facility } \\
\hline Onsite worker & $100 \mathrm{~m} \mathrm{E}$ & $7.31 \mathrm{E}+00$ & $7.35 \mathrm{E}+00$ & $1.20 \mathrm{E}+02$ \\
\hline Columbia River & $650 \mathrm{~m} \mathrm{~W}$ & $1.84 \mathrm{E}+01$ & $2.19 \mathrm{E}+02$ & $2.20 \mathrm{E}+02$ \\
\hline 100 Area Fire Station & $3,750 \mathrm{~m} \mathrm{ESE}$ & $3.34 \mathrm{E}+03$ & $3.36 \mathrm{E}+03$ & $5.50 \mathrm{E}+04$ \\
\hline Hanford Site boundary & $10,090 \mathrm{~m} \mathrm{~W}$ & $1.00 \mathrm{E}+03$ & $1.19 \mathrm{E}+04$ & $1.20 \mathrm{E}+04$ \\
\hline \multicolumn{5}{|c|}{ Canister Storage Building } \\
\hline Onsite worker & $100 \mathrm{~m} \mathrm{E}$ & $1.57 \mathrm{E}+01$ & $1.58 \mathrm{E}+01$ & $2.58 \mathrm{E}+02$ \\
\hline Highway 240 & $9,280 \mathrm{~m} \mathrm{~W}$ & $1.90 \mathrm{E}+03$ & $2.27 \mathrm{E}+04$ & $2.28 \mathrm{E}+04$ \\
\hline Hanford Site boundary & $17,390 \mathrm{~m} \mathrm{E}$ & $3.45 \mathrm{E}+03$ & $4.11 \mathrm{E}+04$ & $4.14 \mathrm{E}+04$ \\
\hline
\end{tabular}

The assumed release is at ground level and has a duration of 15 minutes. 


\subsection{COMPARISON OF TOXICOLOGICAL AND RADIOLOGICAL IMPORTANCE}

Because any environmental release of SNF could have toxicological and radiological effects, both should be computed for comparison with consequence guidelines. The methods for evaluating the importance of radiological and toxicological emissions from SNF Project facilities have been presented in previous sections. Comparison of Tables 3-6 and 4-6 reveals that more grams of SNF must be released to reach the toxicological risk evaluation guideline than the radiological for each accident frequency range and receptor location. A more rigorous comparison will be presented in this section by using a ratio of radiological and toxicological ratios. The radiological (or toxicological) ratio shows the importance of a given release by comparing the resulting dose (or air concentration) with the risk evaluation guidelines. The ratio of these radiological and toxicological ratios simplifies the comparison so that a broader variety of accident conditions can be evaluated.

The formulas used to calculate the radiological and toxicological significance of airborne releases from SNF facilities are shown below. For the purposes of comparison, the radiological consequence formula has been written as the dose equivalent divided by the radiological risk evaluation guideline. Both radiological and toxicological consequences are thereby reduced to unitless, risk-based ratios. The utility of risk-based ratios is that accidents having a ratio greater than 1.0 requires additional controls to lessen either the severity or probability of the accident.

$$
\begin{gathered}
\text { Radiological ratio }=(\mathrm{M})\left(\chi / \mathrm{Q}^{\prime}\right)(\mathrm{BR})(\mathrm{UD}) /(\mathrm{RRG}) \\
\text { Toxicological ratio }=(\mathrm{M})\left(\chi / \mathrm{Q}^{\prime}\right)(\mathrm{CWRG}) / \min \left[\mathrm{T}_{\text {guiclo }}, \max \left(\mathrm{T}_{\text {rel }}, \mathrm{T}_{\text {ave }}\right)\right]
\end{gathered}
$$

where

$$
\begin{aligned}
\mathrm{M} & =\text { mass of SNF released into the air as respirable particles, } g \text { fuel } \\
\chi / \mathrm{Q}^{\prime} & \left.=\text { air transport factor, } \mathrm{s} / \mathrm{m}^{3} \text { (Tables } 2-4 \text { and } 2-5\right) \\
\mathrm{BR} & =\text { average inhalation rate during the release, } \mathrm{m}^{3} / \mathrm{s} \\
\mathrm{UD} & =\text { committed EDE per gram inhaled, } 4380 \mathrm{~Sv} / \mathrm{g}(\mathrm{Table} 3-1) \\
\mathrm{RRG} & =\text { radiological risk evaluation guideline, Sv (Table } 1-1) \\
\mathrm{CWRG} & \left.=\text { spent fuel composition-weighted risk guideline, } \mathrm{m}^{3} / \mathrm{g} \text { of fuel (Table } 4-3\right) \\
\mathrm{T}_{\text {guide }} & =\text { time period characteristic of the toxicological risk guideline, } \mathrm{s} \\
\mathrm{T}_{\mathrm{rcl}} & =\text { release duration, } \mathrm{s} \\
\mathrm{T}_{\text {avc }} & =\text { exposure averaging period, } 900 \text { seconds. }
\end{aligned}
$$


The air transport factors for toxic chemicals never use the puff values because the puff-toplume transition times are all less than the exposure averaging time of 900 seconds. Thus the same air transport factors are always used in both the radiological and toxicological calculations. When the ratio of radiological to toxicological is computed, the quantity released (M) and the air transport factors $\left(\chi / Q^{\prime}\right)$ cancel out. The resulting simplified ratio is shown below.

$$
\frac{\text { Radiological ratio }}{\text { Toxicological ratio }}=\frac{(\mathrm{BR})(\mathrm{UD}) \min \left(\mathrm{T}_{\text {guide }}, \max \left(\mathrm{T}_{\text {rel }} \mathrm{T}_{\text {ave }}\right)\right)}{(\mathrm{RRG})(\mathrm{CWRG})}
$$

To minimize this ratio, the shortest time possible should be selected for the release duration. This shortest time is the exposure averaging time, 15 minutes (900 seconds). The numerator is then $1,310\left(\mathrm{~Sv} \mathrm{~m}^{3}\right) / \mathrm{g} \mathrm{U}$. The denominator comes from Tables 1-1 and 4-3, and depends on the location of the receptor (onsite or offsite) and the accident probability. Values for the above ratios of radiological to toxicological consequences were computed for each case. Results are shown in Table 5-1. The radiological ratios are greater than the toxicological ratios for any mass released and any release duration.

Table 5-1. Radiological Ratios Divided by Toxicological Ratios.

\begin{tabular}{|c|c|c|c|}
\hline \multirow{2}{*}{ Receptor type } & \multicolumn{3}{|c|}{ Accident frequency } \\
\cline { 2 - 4 } & $\begin{array}{c}\text { Anticipated } \\
<0.01 / y\end{array}$ & $\begin{array}{c}\text { Unlikely } \\
0.01 \text { to 1 E-04/y }\end{array}$ & Extremely unlikely \\
\hline Onsite & 78 & 7.8 & 51 \\
\hline Offsite & 13 & 16 & 16 \\
\hline
\end{tabular}

The assumed release duration is at most 15 minutes. Larger release durations increase the ratios shown above due to smaller toxicological consequences.

The preferential release of specific constituents in the spent fuel rather than the complete composition could affect the above ratios. If the radiological ratio decreases more than the toxicological ratio, then the toxicological consequences could dominate. In order for the toxicological risk to dominate, the plutonium and americium (which constitute most of the radiological risk) would have to be left behind. However, the plutonium and americium are an inescapable part of the uranium fuel. If they are not released, then the majority of the mass is also not released. This means that the toxicological constituents will only be present in trace amounts. Minuscule emissions cannot present a toxicological hazard downwind. Thus it can be stated that for all accidents involving SNF, the radiological risk guidelines are more limiting than the toxicological guidelines. In other words, if the radiological risk is brought within radiological guidelines, the toxicological risk is below toxicological guidelines with margin. 


\subsection{REFERENCES}

10 CFR 72, "Licensing Requirements for the Independent Storage of Spent Nuclear Fuel and High-Level Radioactive Waste," Code of Federal Regulations, as amended.

AIHA, 1991, Emergency Response Planning Guidelines, American Industrial Hygiene Association, Akron, Ohio.

Craig, D. K., 1995, Toxic Chemical Hazard Classification and Risk Acceptance Guidelines for Use in DOE Facilities, WSRC-MS-92-206, Rev. 2, Westinghouse Savannah River Company, Aiken, South Carolina.

Craig, D. K., 1997, ERPGs and TEELs for Chemicals of Concern at SRS: Rev. 12 (July 9, 1997), PEC-CAT-97-0044A

DOE-0223, 1994, Emergency Implementation Procedures, U.S. Department of Energy, Richland Field Office, Richland, Washington.

DOE-HDBK-3010, 1994, Airborne Release Fractions/Rates and Respirable Fractions/Rates for Nonreactor Nuclear Facilities, U.S. Department of Energy, Washington, D.C.

EPA, 1992, Manual of Protective Action Guides and Protective Actions for Nuclear Incidents, U.S. Environmental Protection Agency, Washington, D.C.

Federal Guidance Report No. 11, 1988, Limiting Values of Radionuclide Intake and Air Concentration and Dose Conversion Factors for Inhalation, Submersion, and Ingestion, EPA-520/1-88-020, U.S. Environmental Protection Agency, Washington, D.C.

Federal Guidance Report No. 12, 1993, External Exposure to Radionuclides in Air, Water, and Soil, EPA402-R-93-081, U.S. Environmental Protection Agency, Washington, D.C.

HNF-SD-SNF-TI-015, 1998, Spent Nuclear Fuel Project Technical Databook, Rev. 6, Fluor Daniel Hanford, Incorporated, Richland, Washington.

ICRP Publication 23, 1975, Report of the Task Group on Reference Man, International Commission on Radiological Protection, Elmsford, New York.

ICRP Publication 26, 1977, Recommendations of the International Commission on Radiological Protection, International Commission on Radiological Protection, Elmsford, New York.

ICRP Publication 41, 1984, Non-Stochastic Effects of Ionizing Radiation, International Commission on Radiological Protection, Elmsford, New York.

NRC Regulatory Guide 1.145, 1982, Atmospheric Dispersion Models for Potential Accident Consequence Assessments at Nuclear Power Plants, U.S. Nuclear Regulatory Commission, Washington, D.C. 
NUREG/CR-4691 (SAND86-1562), 1990, MELCOR Accident Consequence Code System $(M A C C S)$, Sandia National Laboratories, Albuquerque, New Mexico.

PNL-6584, 1988, GENII - The Hanford Environmental Radiation Dosimetry Software System, Vol. 1, UC-600, Pacific Northwest Laboratory, Richland, Washington.

Sellers, E. D., 1996, Clarification of Site Boundary for Spent Nuclear Fuel Project (SNFP) Work in or Near K Basins (Letter 96-SFD-1 13 to President, Westinghouse Hanford Company, May 22), U.S. Department of Energy, Richland Operations Office, Richland, Washington.

Sellers, E. D., 1997, Risk Evaluation Guidelines (REGs) to Ensure Inherently Safer Designs (Letter 97-SFD-034 to H. J. Hatch, Fluor Daniel Hanford, Incorporated, May 23), U.S. Department of Energy, Richland Operations Office, Richland, Washington.

WHC-SD-GN-SWD-30002, 1993, GXQ Program Users' Guide, Rev. 0, Westinghouse Hanford Company, Richland, Washington.

WHC-SD-GN-SWD-30003, 1993, GXQ Program Verification and Validation, Rev. 0, Westinghouse Hanford Company, Richland, Washington.

WHC-SD-WM-SAR-016, 1996, Tank Waste Compositions and Atmospheric Dispersion Coefficients for Use in Safety Analysis Consequence Assessments, Rev. 2, Westinghouse Hanford Company, Richland, Washington..

WSDOA, 1994, Fixed Nuclear Facility Emergency Response Procedure, Section 10.6, Washington State Department of Agriculture, Olympia, Washington.

WSDOH, 1993, Response Procedures for Radiation Emergencies, Appendix A, Protective Action Guides, Washington State Department of Health, Olympia, Washington. 
HNF-SD-SNF-TI-059 REV 2

APPENDIX A

GROUND-LEVEL AIR TRANSPORT FACTORS

FOR EACH WIND DIRECTION 
HNF-SD-SNF-TI-059 REV 2

This page intentionally left blank. 
Table A-1. Air Transport Factors for Releases from 105-KW to Hanford Site Boundary Locations.

\begin{tabular}{|c|c|c|c|c|c|}
\hline \multirow{2}{*}{$\begin{array}{c}\text { Transport } \\
\text { direction }\end{array}$} & \multirow{2}{*}{$\begin{array}{c}\text { Distance } \\
(m)\end{array}$} & \multicolumn{4}{|c|}{ Air transport factors } \\
\cline { 3 - 6 } & Bounding & Meander & Chronic & Puff \\
\hline S & 25,150 & $9.38 \mathrm{E}-06$ & $8.16 \mathrm{E}-06$ & $2.69 \mathrm{E}-08$ & $9.69 \mathrm{E}-09$ \\
\hline SSW & 17,310 & $1.12 \mathrm{E}-05$ & $9.57 \mathrm{E}-06$ & $2.91 \mathrm{E}-08$ & $1.37 \mathrm{E}-08$ \\
\hline SW & 15,660 & $1.38 \mathrm{E}-05$ & $1.15 \mathrm{E}-05$ & $3.60 \mathrm{E}-08$ & $1.69 \mathrm{E}-08$ \\
\hline WSW & 12,040 & $2.02 \mathrm{E}-05$ & $1.61 \mathrm{E}-05$ & $6.46 \mathrm{E}-08$ & $5.42 \mathrm{E}-08$ \\
\hline W & 10,070 & $4.49 \mathrm{E}-05$ & $3.12 \mathrm{E}-05$ & $1.58 \mathrm{E}-07$ & $1.07 \mathrm{E}-07$ \\
\hline WNW & 8,650 & $3.05 \mathrm{E}-05$ & $2.27 \mathrm{E}-05$ & $1.22 \mathrm{E}-07$ & $9.95 \mathrm{E}-08$ \\
\hline NW & 8,650 & $2.88 \mathrm{E}-05$ & $2.15 \mathrm{E}-05$ & $9.93 \mathrm{E}-08$ & $7.02 \mathrm{E}-08$ \\
\hline NNW & 8,650 & $1.42 \mathrm{E}-05$ & $1.28 \mathrm{E}-05$ & $6.93 \mathrm{E}-08$ & $3.87 \mathrm{E}-08$ \\
\hline N & 8,810 & $2.65 \mathrm{E}-05$ & $2.01 \mathrm{E}-05$ & $8.58 \mathrm{E}-08$ & $4.02 \mathrm{E}-08$ \\
\hline NNE & 10,910 & $1.10 \mathrm{E}-05$ & $1.05 \mathrm{E}-05$ & $5.16 \mathrm{E}-08$ & $2.43 \mathrm{E}-08$ \\
\hline NE & 15,190 & $1.47 \mathrm{E}-05$ & $1.22 \mathrm{E}-05$ & $4.77 \mathrm{E}-08$ & $2.76 \mathrm{E}-08$ \\
\hline ENE & 19,880 & $1.67 \mathrm{E}-05$ & $1.37 \mathrm{E}-05$ & $5.30 \mathrm{E}-08$ & $2.44 \mathrm{E}-08$ \\
\hline E & 20,380 & $2.31 \mathrm{E}-05$ & $1.84 \mathrm{E}-05$ & $8.41 \mathrm{E}-08$ & $2.55 \mathrm{E}-08$ \\
\hline ESE & 20,570 & $1.79 \mathrm{E}-05$ & $1.46 \mathrm{E}-05$ & $5.04 \mathrm{E}-08$ & $2.13 \mathrm{E}-08$ \\
\hline SE & 21,700 & $1.36 \mathrm{E}-05$ & $1.14 \mathrm{E}-05$ & $3.48 \mathrm{E}-08$ & $1.52 \mathrm{E}-08$ \\
\hline SSE & 25,150 & $9.57 \mathrm{E}-06$ & $8.31 \mathrm{E}-06$ & $2.43 \mathrm{E}-08$ & $8.89 \mathrm{E}-09$ \\
\hline$\therefore$ & Sector Maximum: & $4.49 \mathrm{E}-05$ & $3.12 \mathrm{E}-05$ & $1.58 \mathrm{E}-07$ & $1.07 \mathrm{E}-07$ \\
\hline Overall Site $(95 \%):$ & $2.65 \mathrm{E}-05$ & $2.00 \mathrm{E}-05$ & $6.48 \mathrm{E}-08$ & $4.19 \mathrm{E}-08$ \\
\hline
\end{tabular}

Units for distances are meters. Units for bounding, meander, and chronic coefficients are $\mathrm{s} / \mathrm{m}^{3}$. Units for puff coefficients are $1 / \mathrm{m}^{3}$. Directions are for travel from the $105-\mathrm{KW}$ facility to the Hanford Site boundary (wind toward). 
Table A-2. Air Transport Factors for Releases from 105-KW to Columbia River Locations.

\begin{tabular}{|c|c|c|c|c|c|}
\hline \multirow{2}{*}{$\begin{array}{l}\text { Transport } \\
\text { direction }\end{array}$} & \multirow{2}{*}{$\begin{array}{l}\text { Distance } \\
\text { (m) }\end{array}$} & \multicolumn{4}{|c|}{ Air transport factors } \\
\hline & & Bounding & Meander & Chronic & Puff \\
\hline S & 12,850 & $2.15 \mathrm{E}-05$ & $1.69 \mathrm{E}-05$ & $6.79 \mathrm{E}-08$ & $4.08 \mathrm{E}-08$ \\
\hline SSW & 11,400 & $1.90 \mathrm{E}-05$ & $1.51 \mathrm{E}-05$ & $5.21 \mathrm{E}-08$ & $3.37 \mathrm{E}-08$ \\
\hline SW & 1,060 & $5.81 \mathrm{E}-04$ & $1.78 \mathrm{E}-04$ & $2.15 \mathrm{E}-06$ & $8.08 \mathrm{E}-06$ \\
\hline WSW & 710 & $1.20 \mathrm{E}-03$ & $3.03 \mathrm{E}-04$ & $5.38 \mathrm{E}-06$ & 4.11E-05 \\
\hline W & 520 & $3.55 \mathrm{E}-03$ & $6.17 \mathrm{E}-04$ & $1.79 \mathrm{E}-05$ & 1.23E-04 \\
\hline WNW & 480 & $2.28 \mathrm{E}-03$ & $5.81 \mathrm{E}-04$ & $1.31 \mathrm{E}-05$ & $1.01 \mathrm{E}-04$ \\
\hline NW & 480 & $2.15 \mathrm{E}-03$ & $5.55 \mathrm{E}-04$ & $1.07 \mathrm{E}-05$ & $7.13 \mathrm{E}-05$ \\
\hline NNW & 480 & $1.08 \mathrm{E}-03$ & $4.44 \mathrm{E}-04$ & $7.52 \mathrm{E}-06$ & $3.96 \mathrm{E}-05$ \\
\hline $\mathrm{N}$ & 480 & $2.02 \mathrm{E}-03$ & $5.32 \mathrm{E}-04$ & $9.54 \mathrm{E}-06$ & 4.27E-05 \\
\hline NNE & 530 & $9.36 \mathrm{E}-04$ & $4.15 \mathrm{E}-04$ & $6.47 \mathrm{E}-06$ & $3.19 \mathrm{E}-05$ \\
\hline$N E$ & 730 & $1.11 \mathrm{E}-03$ & $2.84 \mathrm{E}-04$ & $5.34 \mathrm{E}-06$ & $3.22 \mathrm{E}-05$ \\
\hline ENE & 2,250 & $2.94 \mathrm{E}-04$ & $1.15 \mathrm{E}-04$ & $1.25 \mathrm{E}-06$ & $3.08 \mathrm{E}-06$ \\
\hline $\mathrm{E}$ & 11,330 & $4.80 \mathrm{E}-05$ & $3.35 \mathrm{E}-05$ & $1.89 \mathrm{E}-07$ & $9.02 \mathrm{E}-08$ \\
\hline $\mathrm{ESE}$ & 11,780 & $3.58 \mathrm{E}-05$ & $2.60 \mathrm{E}-05$ & $1.09 \mathrm{E}-07$ & $7.06 \mathrm{E}-08$ \\
\hline SE & 15,050 & $2.14 \mathrm{E}-05$ & $1.69 \mathrm{E}-05$ & $5.75 \mathrm{E}-08$ & $3.32 \mathrm{E}-08$ \\
\hline SSE & 15,800 & $1.70 \mathrm{E}-05$ & $1.38 \mathrm{E}-05$ & $4.58 \mathrm{E}-08$ & $2.40 \mathrm{E}-08$ \\
\hline \multicolumn{2}{|c|}{ Sector Maximum: } & $3.55 \mathrm{E}-03$ & $6.17 \mathrm{E}-04$ & $1.79 \mathrm{E}-05$ & $1.23 \mathrm{E}-04$ \\
\hline \multicolumn{2}{|c|}{ Overall Site $(95 \%)$} & $1.58 \mathrm{E}-03$ & $4.25 \mathrm{E}-04$ & $5.00 \mathrm{E}-06$ & 4.02E-05 \\
\hline
\end{tabular}

Units for distances are meters. Units for bounding, meander, and chronic coefficients are $\mathrm{s} / \mathrm{m}^{3}$. Units for puff coefficients are $1 / \mathrm{m}^{3}$. Directions are for travel from the $105-\mathrm{KW}$ facility to the Columbia River and the Hanford Site boundary (wind toward). 
Table A-3. Air Transport Factors at 100 Meters for Releases from $105-\mathrm{KW}$ or the Cold Vacuum Drying Facility.

\begin{tabular}{|c|c|c|c|c|}
\hline \multirow{2}{*}{ Direction } & \multicolumn{4}{|c|}{ Air transport factors } \\
\hline & Bounding & Meander & Chronic & Puff \\
\hline$S$ & $3.88 \mathrm{E}-02$ & $9.03 \mathrm{E}-03$ & $2.29 \mathrm{E}-04$ & $5.73 \mathrm{E}-03$ \\
\hline SSW & $2.91 \mathrm{E}-02$ & $7.71 \mathrm{E}-03$ & $1.48 \mathrm{E}-04$ & $3.17 \mathrm{E}-03$ \\
\hline SW & $3.17 \mathrm{E}-02$ & $8.12 \mathrm{E}-03$ & $1.56 \mathrm{E}-04$ & $3.72 \mathrm{E}-03$ \\
\hline WSW & $3.36 \mathrm{E}-02$ & $8.48 \mathrm{E}-03$ & $1.89 \mathrm{E}-04$ & $6.75 \mathrm{E}-03$ \\
\hline W & $5.91 \mathrm{E}-02$ & $1.03 \mathrm{E}-02$ & $3.63 \mathrm{E}-04$ & $9.04 \mathrm{E}-03$ \\
\hline WNW & $3.33 \mathrm{E}-02$ & $8.46 \mathrm{E}-03$ & $2.33 \mathrm{E}-04$ & $6.05 \mathrm{E}-03$ \\
\hline NW & $3.13 \mathrm{E}-02$ & $8.08 \mathrm{E}-03$ & $1.91 \mathrm{E}-04$ & $4.28 \mathrm{E}-03$ \\
\hline NNW & $1.58 \mathrm{E}-02$ & $6.51 \mathrm{E}-03$ & $1.34 \mathrm{E}-04$ & $2.38 \mathrm{E}-03$ \\
\hline $\mathrm{N}$ & $2.94 \mathrm{E}-02$ & $7.75 \mathrm{E}-03$ & $1.70 \mathrm{E}-04$ & $2.56 \mathrm{E}-03$ \\
\hline NNE & $1.61 \mathrm{E}-02$ & $7.15 \mathrm{E}-03$ & $1.37 \mathrm{E}-04$ & $2.47 \mathrm{E}-03$ \\
\hline $\mathrm{NE}$ & $3.27 \mathrm{E}-02$ & 8.33E-03 & $2.00 \mathrm{E}-04$ & $5.70 \mathrm{E}-03$ \\
\hline ENE & $5.16 \mathrm{E}-02$ & 1.01E-02 & $3.13 \mathrm{E}-04$ & $8.94 \mathrm{E}-03$ \\
\hline $\mathrm{E}$ & $7.32 \mathrm{E}-02$ & 1:24E-02 & $5.12 \mathrm{E}-04$ & $9.85 \mathrm{E}-03$ \\
\hline ESE & $5.76 \mathrm{E}-02$ & $1.03 \mathrm{E}-02$ & $3.15 \mathrm{E}-04$ & $8.39 \mathrm{E}-03$ \\
\hline SE & $4.69 \mathrm{E}-02$ & $9.53 \mathrm{E}-03$ & $2.36 \mathrm{E}-04$ & $6.71 \mathrm{E}-03$ \\
\hline SSE & $3.95 \mathrm{E}-02$ & $9.03 \mathrm{E}-03$ & $2.01 \mathrm{E}-04$ & $5.38 \mathrm{E}-03$ \\
\hline $\begin{array}{c}\text { Sector } \\
\text { Maximum: }\end{array}$ & $7.32 \mathrm{E}-02$ & $1.24 \mathrm{E}-02$ & $5.12 \mathrm{E}-04$ & $9.85 \mathrm{E}-03$ \\
\hline $\begin{array}{c}\text { Overall Site } \\
(95 \%)\end{array}$ & $6.10 \mathrm{E}-02$ & $1.03 \mathrm{E}-02$ & $2.33 \mathrm{E}-04$ & $8.83 \mathrm{E}-03$ \\
\hline
\end{tabular}

Units for bounding, meander, and chronic coefficients are $\mathrm{s} / \mathrm{m}^{3}$. Units for puff coefficients are $1 / \mathrm{m}^{3}$. Directions are for travel from the release point to a distance of $100 \mathrm{~m}$ (wind toward). 
Table A-4. Air Transport Factors for Releases from the Cold Vacuum Drying Facility to Columbia River Locations.

\begin{tabular}{|c|c|c|c|c|c|}
\hline \multirow{2}{*}{$\begin{array}{l}\text { Transport } \\
\text { direction }\end{array}$} & \multirow{2}{*}{$\begin{array}{l}\text { Distance } \\
\text { (m) }\end{array}$} & \multicolumn{4}{|c|}{ Air transport factors } \\
\hline & & Bounding. & Meander & Chronic & Puff \\
\hline $\mathrm{S}$ & 12,650 & $2.20 \mathrm{E}-05$ & $1.72 \mathrm{E}-05$ & $6.94 \mathrm{E}-08$ & $4.22 \mathrm{E}-08$ \\
\hline SSW & 11,340 & $1.91 \mathrm{E}-05$ & $1.52 \mathrm{E}-05$ & $5.25 \mathrm{E}-08$ & $3.41 \mathrm{E}-08$ \\
\hline SW & 1,690 & $2.76 \mathrm{E}-04$ & $1.11 \mathrm{E}-04$ & $9.74 \mathrm{E}-07$ & $2.52 \mathrm{E}-06$ \\
\hline WSW & 700 & $1.23 \mathrm{E}-03$ & $3.10 \mathrm{E}-04$ & $5.52 \mathrm{E}-06$ & $4.26 \mathrm{E}-05$ \\
\hline W & 650 & $2.44 \mathrm{E}-03$ & $4.25 \mathrm{E}-04$ & $1,21 \mathrm{E}-05$ & $6.90 \mathrm{E}-05$ \\
\hline WNW & 580 & $1.66 \mathrm{E}-03$ & 4.23E-04 & $9.38 \mathrm{E}-06$ & $6.19 \mathrm{E}-05$ \\
\hline NW & 580 & $1.56 \mathrm{E}-03$ & $4.04 \mathrm{E}-04$ & $7.66 \mathrm{E}-06$ & $4.38 \mathrm{E}-05$ \\
\hline NNW & 580 & $7.89 \mathrm{E}-04$ & $3.24 \mathrm{E}-04$ & $5.37 \mathrm{E}-06$ & $2.43 \mathrm{E}-05$ \\
\hline $\mathrm{N}$ & 580 & $1.47 \mathrm{E}-03$ & $3.88 \mathrm{E}-04$ & $6.81 \mathrm{E}-06$ & $2.62 \mathrm{E}-05$ \\
\hline NNE & 640 & $6.84 \mathrm{E}-04$ & $3.03 \mathrm{E}-04^{\circ}$ & $4.62 \mathrm{E}-06$ & $1.96 \mathrm{E}-05$ \\
\hline $\mathrm{NE}$ & 860 & $8.48 \mathrm{E}-04$ & $2.27 \mathrm{E}-04$ & $4.00 \mathrm{E}-06$ & $2.12 \mathrm{E}-05$ \\
\hline ENE & 2,540 & $2.47 \mathrm{E}-04$ & $1.03 \mathrm{E}-04$ & $1.04 \mathrm{E}-06$ & $2.32 \mathrm{E}-06$ \\
\hline $\mathrm{E}$ & 11,470 & $4.73 \mathrm{E}-05$ & $3.31 \mathrm{E}-05$ & $1.86 \mathrm{E}-07$ & 8.79E-08 \\
\hline ESE & 12,060 & $3.48 \mathrm{E}-05$ & $2.54 \mathrm{E}-05$ & $1.05 \mathrm{E}-07$ & $6.71 \mathrm{E}-08$ \\
\hline SE & 15,150 & $2.13 \mathrm{E}-05$ & $1.67 \mathrm{E}-05$ & $5.70 \mathrm{E}-08$ & $3.28 \mathrm{E}-08$ \\
\hline SSE & 15,600 & $1.72 \mathrm{E}-05$ & $1.40 \mathrm{E}-05$ & $4.66 \mathrm{E}-08$ & $2.46 \mathrm{E}-08$ \\
\hline \multicolumn{2}{|c|}{ Sector Maximum: } & $2.44 \mathrm{E}-03$ & $4.25 \mathrm{E}-04$ & $1.21 \mathrm{E}-05$ & $6.90 \mathrm{E}-05$ \\
\hline \multicolumn{2}{|c|}{ Overall Site $(95 \%)$} & $1.22 \mathrm{E}-03$ & 3.14E-04 & $3.62 \mathrm{E}-06$ & $2.30 \mathrm{E}-05$ \\
\hline
\end{tabular}

Units for distances are meters. Units for bounding, meander, and chronic coefficients are $\mathrm{s} / \mathrm{m}^{3}$. Units for puff coefficients are $1 / \mathrm{m}^{3}$. Directions are for travel from the Cold Vacuum Drying Facility to the Columbia River and the Hanford Site boundary (wind toward). 
Table A-5. Air Transport Factors for Releases from the Cold Vacuum Drying Facility to Hanford Site Boundary Locations.

\begin{tabular}{|c|c|c|c|c|c|}
\hline \multirow{2}{*}{$\begin{array}{l}\text { Transport } \\
\text { direction }\end{array}$} & \multirow{2}{*}{$\begin{array}{c}\text { Distance } \\
(\mathrm{m})\end{array}$} & \multicolumn{4}{|c|}{ Air transport factors } \\
\hline & & Bounding & Meander & Chronic & Puff \\
\hline $\mathrm{S}$ & 24,960 & $9.47 \mathrm{E}-06$ & $8.23 \mathrm{E}-06$ & $2.72 \mathrm{E}-08$ & $9.85 \mathrm{E}-09$ \\
\hline SSW & 17,130 & 1.14E-05 & $9.68 \mathrm{E}-06$ & $2.95 \mathrm{E}-08$ & $1.40 \mathrm{E}-08$ \\
\hline SW & 15,510 & $1.40 \mathrm{E}-05$ & $1.16 \mathrm{E}-05$ & $3.65 \mathrm{E}-08$ & $1.72 \mathrm{E}-08$ \\
\hline WSW & 11,990 & $2.03 \mathrm{E}-05$ & $1.62 \mathrm{E}-05$ & $6.50 \mathrm{E}-08$ & $5.46 \mathrm{E}-08$ \\
\hline W & 10,090 & $4.48 \mathrm{E}-05$ & $3.11 \mathrm{E}-05$ & $1.58 \mathrm{E}-07$ & $1.07 \mathrm{E}-07$ \\
\hline WNW & 8,740 & $3.01 \mathrm{E}-05$ & $2.25 \mathrm{E}-05$ & $1.20 \mathrm{E}-07$ & $9.73 \mathrm{E}-08$ \\
\hline NW & 8,740 & $2.84 \mathrm{E}-05$ & $2.13 \mathrm{E}-05$ & $9.79 \mathrm{E}-08$ & $6.86 \mathrm{E}-08$ \\
\hline NNW & 8,740 & $1.41 \mathrm{E}-05$ & $1.27 \mathrm{E}-05$ & $6.83 \mathrm{E}-08$ & $3.78 \mathrm{E}-08$ \\
\hline $\mathrm{N}$ & 8,930 & $2.61 \mathrm{E}-05$ & $1.98 \mathrm{E}-05$ & $8.41 \mathrm{E}-08$ & $3.90 \mathrm{E}-08$ \\
\hline NNE & 10,750 & $1.12 \mathrm{E}-05$ & $1.07 \mathrm{E}-05$ & $5.27 \mathrm{E}-08$ & $2.51 \mathrm{E}-08$ \\
\hline NE & 15,390 & $1.45 \mathrm{E}-05$ & $1.21 \mathrm{E}-05$ & $4.68 \mathrm{E}-08$ & $2.69 \mathrm{E}-08$ \\
\hline ENE & 20,080 & $1.65 \mathrm{E}-05$ & $1.35 \mathrm{E}-05$ & $5.22 \mathrm{E}-08$ & $2.39 \mathrm{E}-08$ \\
\hline $\mathrm{E}$ & 20,510 & $2.29 \mathrm{E}-05$ & $1.83 \mathrm{E}-05$ & $8.34 \mathrm{E}-08$ & $2.52 \mathrm{E}-08$ \\
\hline ESE & 20,670 & $1.78 \mathrm{E}-05$ & $1.45 \mathrm{E}-05$ & $5.01 \mathrm{E}-08$ & $2.11 \mathrm{E}-08$ \\
\hline $\mathrm{SE}$ & 21,790 & $1.36 \mathrm{E}-05$ & $1.13 \mathrm{E}-05$ & $3.46 \mathrm{E}-08$ & $1.51 \mathrm{E}-08$ \\
\hline SSE & 24,960 & $9.65 \mathrm{E}-06$ & $8.38 \mathrm{E}-06$ & $2.45 \mathrm{E}-08$ & $9.03 \mathrm{E}-09$ \\
\hline \multicolumn{2}{|c|}{ Sector Maximum: } & $4.48 \mathrm{E}-05$ & $3.11 \mathrm{E}-05$ & $1.58 \mathrm{E}-07$ & $1.07 \mathrm{E}-07$ \\
\hline \multicolumn{2}{|c|}{ Overall Site $(95 \%)$} & $2.62 \mathrm{E}-05$ & $2.03 \mathrm{E}-05$ & $6.44 \mathrm{E}-08$ & $4.07 \mathrm{E}-08$ \\
\hline
\end{tabular}

Units for distances are meters. Units for bounding, meander, and chronic coefficients are $\mathrm{s} / \mathrm{m}^{3}$. Units for puff coefficients are $1 / \mathrm{m}^{3}$. Directions are for travel from the Cold Vacuum Drying Facility to the Hanford Site boundary (wind toward). 
Table A-6. Air Transport Factors at 100 Meters from the

Canister Storage Building.

\begin{tabular}{|c|c|c|c|c|}
\hline \multirow{2}{*}{ Direction } & \multicolumn{4}{|c|}{ Air transport factors } \\
\hline & Bounding & Meander & Chronic & Puff \\
\hline $\mathrm{S}$ & $1.56 \mathrm{E}-02$ & $5.96 \mathrm{E}-03$ & $1.68 \mathrm{E}-04$ & $2.25 \mathrm{E}-03$ \\
\hline SSW & $1.13 \mathrm{E}-02$ & 4.54E-03 & $1.04 \mathrm{E}-04$ & $1.36 \mathrm{E}-03$ \\
\hline SW & $1.21 \mathrm{E}-02$ & 4.80E-03 & $9.93 \mathrm{E}-05$ & $8.69 \mathrm{E}-04$ \\
\hline WSW & $1.22 \mathrm{E}-02$ & 4.80E-03 & $9.97 \mathrm{E}-05$ & $8.43 \mathrm{E}-04$ \\
\hline W & $2.80 \mathrm{E}-02$ & 7.43E-03 & $1.73 \mathrm{E}-04$ & $2.53 \mathrm{E}-03$ \\
\hline WNW & $1.60 \mathrm{E}-02$ & $6.67 \mathrm{E}-03$ & $1.39 \mathrm{E}-04$ & $2.55 \mathrm{E}-03$ \\
\hline NW & $2.89 \mathrm{E}-02$ & $7.65 \mathrm{E}-03$ & $1.57 \mathrm{E}-04$ & $5.36 \mathrm{E}-03$ \\
\hline NNW & $2.90 \mathrm{E}-02$ & $8.06 \mathrm{E}-03$ & $1.54 \mathrm{E}-04$ & $7.02 \mathrm{E}-03$ \\
\hline $\mathrm{N}$ & $3.12 \mathrm{E}-02$ & $8.29 \mathrm{E}-03$ & $1.61 \mathrm{E}-04$ & $6.99 \mathrm{E}-03$ \\
\hline NNE & $1.54 \mathrm{E}-02$ & $5.36 \mathrm{E}-03$ & $9.04 \mathrm{E}-05$ & $2.38 \mathrm{E}-03$ \\
\hline $\mathrm{NE}$ & $1.57 \mathrm{E}-02$ & $6.02 \mathrm{E}-03$ & $1.07 \mathrm{E}-04$ & $2.74 \mathrm{E}-03$ \\
\hline $\mathrm{ENE}$ & $2.52 \mathrm{E}-02$ & $7.79 \mathrm{E}-03$ & $1.42 \mathrm{E}-04$ & $6.49 \mathrm{E}-03$ \\
\hline $\mathrm{E}$ & $3.41 \mathrm{E}-02$ & $1.09 \mathrm{E}-02$ & $3.78 \mathrm{E}-04$ & $9.85 \mathrm{E}-03$ \\
\hline ESE & $3.25 \mathrm{E}-02$ & $1.13 \mathrm{E}-02$ & $4.03 \mathrm{E}-04$ & $9.85 \mathrm{E}-03$ \\
\hline SE & $3.07 \mathrm{E}-02$ & $8.37 \mathrm{E}-03$ & $2.52 \mathrm{E}-04$ & $8.35 \mathrm{E}-03$ \\
\hline SSE & $1.58 \mathrm{E}-02$ & $6.20 \mathrm{E}-03$ & $1.47 \mathrm{E}-04$ & $2.52 \mathrm{E}-03$ \\
\hline $\begin{array}{c}\text { Sector } \\
\text { Maximum: }\end{array}$ & $3.41 \mathrm{E}-02$ & $1.13 \mathrm{E}-02$ & 4.03E-04 & $9.85 \mathrm{E}-03$ \\
\hline $\begin{array}{c}\text { Overall } \\
\text { Site (95\%): }\end{array}$ & $3.28 \mathrm{E}-02$ & $9.40 \mathrm{E}-03$ & $1.74 \mathrm{E}-04$ & $7.27 \mathrm{E}-03$ \\
\hline
\end{tabular}

Units for bounding, meander, and chronic coefficients are $s / \mathrm{m}^{3}$. Units for puff coefficients are $1 / \mathrm{m}^{3}$. Directions are for travel from the release point to a distance of $100 \mathrm{~m}$ (wind toward). 
Table A-7. Air Transport Factors for Releases from the Canister Storage Building to Nearest Public Access Locations.

\begin{tabular}{|c|c|c|c|c|c|}
\hline \multirow{2}{*}{$\begin{array}{l}\text { Transport } \\
\text { direction }\end{array}$} & \multirow{2}{*}{$\begin{array}{l}\text { Distance } \\
\text { (m) }\end{array}$} & \multicolumn{4}{|c|}{ Air transport factors } \\
\hline & & Bounding & Meander & Chronic & Puff \\
\hline $\mathrm{S}$ & 7,830 & $1.57 \mathrm{E}-05$ & $1.35 \mathrm{E}-05$ & $9.22 \mathrm{E}-08$ & $4.83 \mathrm{E}-08$ \\
\hline SSW & 7,830 & $9.66 \mathrm{E}-06$ & $8.29 \mathrm{E}-06$ & $5.56 \mathrm{E}-08$ & $3.65 \mathrm{E}-08$ \\
\hline SW & 7,830 & $1.25 \mathrm{E}-05$ & $1.01 \mathrm{E}-05$ & $5.48 \mathrm{E}-08$ & $1.66 \mathrm{E}-08$ \\
\hline WSW & 7,830 & $1.25 \mathrm{E}-05$ & $1.01 \mathrm{E}-05$ & $5.47 \mathrm{E}-08$ & $1.61 E-08$ \\
\hline $\mathrm{W}$ & 9,280 & $2.36 \mathrm{E}-05$ & $1.81 \mathrm{E}=05$ & $7.67 \mathrm{E}-08$ & $3.54 \mathrm{E}-08$ \\
\hline WNW & 10,510 & $1.14 \mathrm{E}-05$ & $1.06 \mathrm{E}-05$ & $5.31 \mathrm{E}-08$ & $2.72 \mathrm{E}-08$ \\
\hline NW & 11,250 & $1.91 \mathrm{E}-05$ & $1.52 \mathrm{E}-05$ & $5.62 \mathrm{E}-08$ & $4.98 \mathrm{E}-08$ \\
\hline NNW & 11,250 & $1.92 \mathrm{E}-05$ & $1.53 \mathrm{E}-05$ & $5.73 \mathrm{E}-08$ & $6.52 \mathrm{E}-08$ \\
\hline $\mathrm{N}$ & 11,250 & $2.06 \mathrm{E}-05$ & $1.62 \mathrm{E}-05$ & $6.09 \mathrm{E}-08$ & $6.49 \mathrm{E}-08$ \\
\hline NNE & 12,750 & $7.96 \mathrm{E}-06$ & $6.96 \mathrm{E}-06$ & $2.85 \mathrm{E}-08$ & $1.66 \mathrm{E}-08$ \\
\hline $\mathrm{NE}$ & 12,670 & $8.50 \mathrm{E}-06$ & $7.75 \mathrm{E}-06$ & $3.38 \mathrm{E}-08$ & $1.95 \mathrm{E}-08$ \\
\hline ENE & 12,670 & $1.44 \mathrm{E}-05$ & $1.21 \mathrm{E}-05$ & $4.50 \mathrm{E}-08$ & $4.66 \mathrm{E}-08$ \\
\hline $\mathrm{E}$ & 12,670 & $1.92 \mathrm{E}-05$ & $1.54 \mathrm{E}-05$ & $1.23 \mathrm{E}-07$ & $7.08 \mathrm{E}-08$ \\
\hline ESE & 14,230 & $1.59 \mathrm{E}-05$ & $1.30 \mathrm{E}-05$ & $1.10 \mathrm{E}-07$ & $5.51 \mathrm{E}-08$ \\
\hline $\mathrm{SE}$ & 11,070 & $2.07 \mathrm{E}-05$ & $1.63 \mathrm{E}-05$ & $9.26 \mathrm{E}-08$ & $8.04 \mathrm{E}-08$ \\
\hline SSE & 8,490 & $1.44 \mathrm{E}-05$ & $1.28 \mathrm{E}-05$ & $7.48 \mathrm{E}-08$ & $4.28 \mathrm{E}-08$ \\
\hline \multicolumn{2}{|c|}{ Sector Maximum: } & $2.36 \mathrm{E}-05$ & $1.81 \mathrm{E}-05$ & $1.23 \mathrm{E}-07$ & $8.04 \mathrm{E}-08$ \\
\hline \multicolumn{2}{|c|}{ Overall Site (95\%): } & $2.02 \mathrm{E}-05$ & $1.59 \mathrm{E}-05$ & $6.68 \mathrm{E}-08$ & $7.00 \mathrm{E}-08$ \\
\hline
\end{tabular}

Units for distances are meters. Units for bounding, meander, and chronic coefficients are $\mathrm{s} / \mathrm{m}^{3}$. Units for puff coefficients are $1 / \mathrm{m}^{3}$. Directions are for travel from the Canister Storage Building to the Hanford Site boundary (wind toward). 
Table A-8. Air Transport Factors for Releases from the Canister Storage Building to Hanford Site Boundary Locations.

\begin{tabular}{|c|c|c|c|c|c|}
\hline \multirow{2}{*}{$\begin{array}{l}\text { Transport } \\
\text { direction }\end{array}$} & \multirow{2}{*}{$\begin{array}{l}\text { Distance } \\
(\mathrm{m})\end{array}$} & \multicolumn{4}{|c|}{ Air transport factors } \\
\hline & & Bounding & Meander & Chronic & Puff \\
\hline $\mathrm{S}$ & 16,260 & $6.05 \mathrm{E}-06$ & $5.56 \mathrm{E}-06$ & $3.23 \mathrm{E}-08$ & $9.88 \mathrm{E}-09$ \\
\hline SSW & 16,260 & $3.83 \mathrm{E}-06$ & $3.53 \mathrm{E}-06$ & $1.94 \mathrm{E}-08$ & $7.42 \mathrm{E}-09$ \\
\hline SW & 16,260 & $4.91 \mathrm{E}-06$ & $4.38 \mathrm{E}-06$ & $1.91 \mathrm{E}-08$ & $3.26 \mathrm{E}-09$ \\
\hline WSW & 17,910 & $4.36 \mathrm{E}-06$ & $3.92 \mathrm{E}-06$ & $1.67 \mathrm{E}-08$ & $2.54 \mathrm{E}-09$ \\
\hline W & 18,400 & $9.97 \mathrm{E}-06$ & 8.57E-06 & $2.92 \mathrm{E}-08$ & 8.07E-09 \\
\hline WNW & 18,400 & $5.59 \mathrm{E}-06$ & $5.36 \mathrm{E}-06$ & $2.42 \mathrm{E}-08$ & $8.14 \mathrm{E}-09$ \\
\hline$N W$ & 18,870 & $1.00 \mathrm{E}-05$ & 8.64E-06 & $2.73 \mathrm{E}-08$ & $1.63 \mathrm{E}-08$ \\
\hline NNW & 19,450 & $9.70 \mathrm{E}-06$ & $8.38 \mathrm{E}-06$ & $2.68 \mathrm{E}-08$ & $2.01 \mathrm{E}-08$ \\
\hline $\mathrm{N}$ & 19,450 & $1.04 \mathrm{E}-05$ & $8.93 \mathrm{E}-06$ & $2.86 \mathrm{E}-08$ & $2.00 \mathrm{E}-08$ \\
\hline NNE & 20,390 & $4.31 \mathrm{E}-06$ & $3.94 \mathrm{E}-06$ & $1.49 \mathrm{E}-08$ & $6.05 \mathrm{E}-09$ \\
\hline NE & 17,540 & $5.60 \mathrm{E}-06$ & $5.23 \mathrm{E}-06$ & $2.15 \mathrm{E}-08$ & $9.69 \mathrm{E}-09$ \\
\hline ENE & 17,390 & $9.69 \mathrm{E}-06$ & $8.46 \mathrm{E}-06$ & $2.90 \mathrm{E}-08$ & $2.36 \mathrm{E}-08$ \\
\hline $\mathrm{E}$ & 17,390 & $1.30 \mathrm{E}-05$ & $1.09 \mathrm{E}-05$ & $7.98 \mathrm{E}-08$ & $3.58 \mathrm{E}-08$ \\
\hline ESE & 17,390 & $1.24 \mathrm{E}-05$ & $1.05 \mathrm{E}-05$ & 8.31E-08 & $3.58 \mathrm{E}-08$ \\
\hline SE & 20,630 & $9.51 \mathrm{E}-06$ & $8.25 \mathrm{E}-06$ & $3.88 \mathrm{E}-08$ & $2.11 \mathrm{E}-08$ \\
\hline SSE & 18,830 & $5.16 \mathrm{E}-06$ & 4.85E-06 & $2.42 \mathrm{E}-08$ & 7.64E-09 \\
\hline \multicolumn{2}{|c|}{ Sector Maximum: } & $1.30 \mathrm{E}-05$ & $1.09 \mathrm{E}-05$ & $8.31 \mathrm{E}-08$ & $3.58 \mathrm{E}-08$ \\
\hline \multicolumn{2}{|c|}{ Overall Site $(95 \%)$} & $1.16 \mathrm{E}-05$ & $9.95 \mathrm{E}-06$ & $3.22 \mathrm{E}-08$ & $3.02 \mathrm{E}-08$ \\
\hline
\end{tabular}

Units for distances are meters. Units for bounding, meander, and chronic coefficients are $\mathrm{s} / \mathrm{m}^{3}$. Units for puff coefficients are $1 / \mathrm{m}^{3}$. Directions are for travel from the Canister Storage Building to the Hanford Site boundary (wind toward). 
HNF-SD-SNF-TI-059 REV 2

\section{APPENDIX B}

\section{GXQ INPUT FILES FOR GROUND-LEVEL RELEASES}


HNF-SD-SNF-TI-059 REV 2

This page intentionally left blank. 
HNF-SD-SNF-TI-059 REV 2

\title{
GXQ Output for Release Durations $<1$ Hour
}

\author{
CVDF \& 100-KW -- 99.5\%
}

\author{
GXQ version 4.0 \\ December 19, 1994 \\ General Purpose Atmospheric Dispersion Code \\ Produced by Westinghouse Hanford Company \\ Users Guide documented in WHC-SD-GN-SWD-30002 Rev. 1. \\ Val idation documented in WHC-SD-GN-SWD-30003 ReV. 1. \\ Code Custodian is: Brit E. Hey \\ West inghouse Hanford Company \\ P.0. $80 \times 1970$ \\ Richland, WA 99352 \\ (509) $376-2921$
}

Run Date $=04 / 09 / 99$

Run $\mathrm{T}$ ime $=14: 43: 25.68$

INPUT ECHO:

Acute -- Ground Level Release Height

c GXQ Version 4.0 Input File

$$
1
$$

c MODE SELECTION:

c 1 - X/Q based on Hanford site specific meteorology

c 2 - X/Q based on atmospheric stability class and wind speed

c 3 - X/Q plot file is created

c SITE WIND \& POPULATION OPTIONS:

$c$ ifox inorm icdf ichk isite ipop

$c$ ifox $=t$ then joint frequency used to compute frequency-to-exceed $X / Q$

$c \quad$ f $\quad f$ then joint frequency used to compute annual average $X / Q$

$c$ inorm $=t$ then joint frequency data is normalized (as in GENII)

c $\quad=f$ then joint frequency data is un-normalized

$c$ icdf $=t$ then cumulative distribution file created (CDF.OUT)

$c \quad=f$ then no cumulative distribution file created

ichk $=t$ then $X / Q$ parameter print option turned on

$=f$ then no parameter print

isite $=t$ then $X / Q$ based on joint frequency data for all 16 sectors

$=f$ then $X / Q$ based on joint frequency data of individual sectors

ipop $=t$ then $X / Q$ is population weighted

$=f$ then no population weighting

c PUFF, DEPOSITION, \& WIND SPEED MODELS:

C ipuff idep isrc iwind

c DIFFUSION COEFFICIENT ADJUSTMENTS:

C i wake ipm iflow ientr

c EFFECTIVE RELEASE HEIGHT ADJUSTMENTS:

c (irise igrnd) iwash igrav

$\begin{array}{llll}0 & 0 & 0 & 0\end{array}$

ipuff $=1$ then $X / Q$ calculated using puff model

$=0$ then $X / Q$ calculated using defaul $t$ continuous plume model

idep $=1$ then plume depletion model turned on (Chamberlain model)

isrc $=1$ then $X / Q$ multiplied by scalar

$=2$ then $X / Q$ adjusted by wind speed function

iwind $=1$ then wind speed corrected for plume height

i wake = 1 then NRC RG 1.145 building wake model turned on

$=2$ then MACCS virtual distance building wake model turned on

$\mathrm{ipm}=1$ then NRC RG 1.145 plume meander model turned on

$=2$ then 5th Power Law plume meander model turned on

$=3$ then sector average model turned on

iflow $=1$ then sigmas adjusted for volume flow rate

ientr $=1$ then method of Pasquill used to account for entrainment

irise $=1$ then MACCS buoyant plume rise model turned on

$=2$ then ISC2 momentum/buoyancy plune rise model turned on 


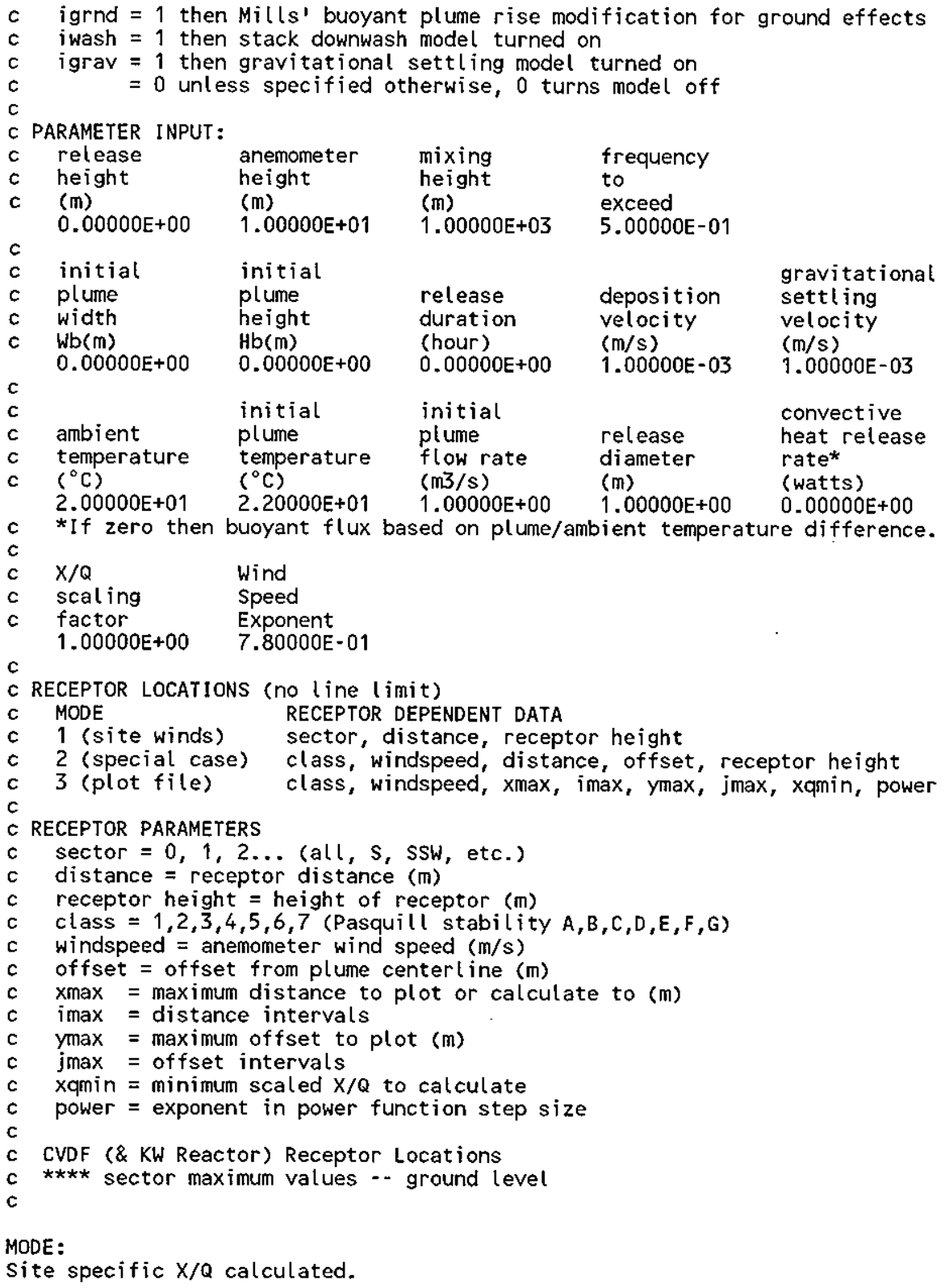

LOGICAL CHOICES:

Joint frequency used to calculate $X / Q$ based on frequency of exceedance.

No normal ization of joint frequency.

$X / Q$ calculated for single sector.

MODELS SELECTED:

Default Gaussian plume model selected.

WARNING/ERROR MESSAGES:

JOINT FREQUENCY DATA:

$100 \mathrm{~N}$ AREA - $10 \mathrm{M}$ - Pasquill A - G (1983 - 1991 Average)

Created $8 / 26 / 92 \mathrm{KR}$

Acute -- Ground Level Release Height 
HNF-SD-SNF-TI-059 REV 2

\begin{tabular}{|c|c|c|c|c|c|c|c|c|}
\hline SECTOR & $\begin{array}{l}\text { DISTANCE } \\
(\mathrm{m})\end{array}$ & $\begin{array}{l}\text { RECEPT } \\
\text { HEIGHT } \\
\text { (m) }\end{array}$ & $\begin{array}{c}\text { SECT. } \\
\text { FREQ. } \\
(\%)\end{array}$ & POPULATION & $\begin{array}{l}\text { TOTAL } \\
\text { POPULATION } \\
\text { SCALED } \\
X / Q \\
(\mathrm{~s} / \mathrm{m} 3)\end{array}$ & $\begin{array}{l}\text { AVERAGE } \\
\text { IND IVIDUAL } \\
\text { SCALED } \\
X / Q \\
(\mathrm{~s} / \mathrm{m} 3)\end{array}$ & $\begin{array}{l}\text { ATM. } \\
\text { STAB. } \\
\text { CLASS }\end{array}$ & $\begin{array}{l}\text { WIND } \\
\text { SPEED } \\
(\mathrm{m} / \mathrm{s})\end{array}$ \\
\hline $\bar{s}$ & 100 & $\overline{0}$ & 6.18 & 1 & $3.88 \mathrm{E}-02$ & $3.88 \mathrm{E}-02$ & $\overline{\mathrm{F}}$ & 0. \\
\hline ssw & 100 & 0 & 5.01 & $i$ & $2.91 \mathrm{E}-02$ & $2.91 \mathrm{E}-02$ & G & 2.6 \\
\hline SW & 100 & 0 & 3.91 & $i$ & $3.17 \mathrm{E}-02$ & $3.17 \mathrm{E}-02$ & & 0. \\
\hline WSW & 100 & 0 & 3.88 & 1 & $3.36 \mathrm{E}-02$ & $3.36 \mathrm{E}-02$ & & 0. \\
\hline W & 100 & 0 & 7.54 & $i$ & $5.91 \mathrm{E}-02$ & $5.91 \mathrm{E}-02$ & $\mathrm{~F}$ & 0 . \\
\hline WNW & 100 & 0 & 5.46 & 1 & $3.33 \mathrm{E}-02$ & $3.33 \mathrm{E}-02$ & $\mathrm{~F}$ & 0. \\
\hline NW & 100 & 0 & 4.92 & 1 & $3.13 \mathrm{E}-02$ & $3.13 \mathrm{E}-02$ & $G$ & 2.65 \\
\hline NNW & 100 & 0 & 3.41 & 1 & $1.58 \mathrm{E}-02$ & $1.58 \mathrm{E}-02$ & G & 4.70 \\
\hline N & 100 & 0 & 3.89 & 1 & $2.94 \mathrm{E}-02$ & $2.94 \mathrm{E}-02$ & & 2.6 \\
\hline NNE & 100 & 0 & 3.54 & 1 & $1.61 \mathrm{E}-02$ & $1.61 \mathrm{E}-02$ & & 4.7 \\
\hline $\mathrm{NE}$ & 100 & 0 & 5.96 & 1 & $3.27 \mathrm{E}-02$ & $3.27 \mathrm{E}-02$ & $\mathbf{F}$ & 0.8 \\
\hline ENE & 100 & 0 & 9.19 & 1 & $5.16 \mathrm{E}-02$ & $5.16 \mathrm{E}-02$ & $\mathrm{~F}$ & 0.8 \\
\hline E & 100 & 0 & 16.14 & 1 & $7.32 \mathrm{E}-02$ & $7.32 \mathrm{E}-02$ & G & 0. \\
\hline ESE & 100 & 0 & 10.16 & 1 & $5.76 \mathrm{E}-02$ & $5.76 \mathrm{E}-02$ & $\mathrm{~F}$ & 0. \\
\hline $\mathrm{SE}$ & 100 & 0 & 6.17 & 1 & $4.69 \mathrm{E}-02$ & $4.69 \mathrm{E}-02$ & $\mathrm{~F}$ & 0.89 \\
\hline SSE & 100 & 0 & 4.44 & 1 & $3.95 \mathrm{E}-02$ & $3.95 \mathrm{E}-02$ & $\mathrm{~F}$ & 0.89 \\
\hline ESE & 3750 & 0 & 10.16 & 1 & $1.60 \mathrm{E}-04$ & $1.60 E-04$ & $\mathrm{~F}$ & 0.89 \\
\hline$s$ & 12650 & 0 & 6.18 & 1 & $2.20 \mathrm{E}-05$ & $2.20 \mathrm{E}-05$ & $\mathrm{~F}$ & 0.89 \\
\hline SSW & 11340 & 0 & 5.01 & $i$ & $1.91 \mathrm{E}-05$ & $1.91 \mathrm{E}-05$ & $G$ & 2.65 \\
\hline SW & 1690 & 0 & 3.91 & $i$ & $2.76 \mathrm{E}-04$ & $2.76 \mathrm{E}-04$ & $\mathrm{~F}$ & 0. \\
\hline WSW & 700 & 0 & 3.88 & 1 & $1.23 \mathrm{E}-03$ & $1.23 \mathrm{E}-03$ & $\mathrm{~F}$ & 0.89 \\
\hline$w$ & 650 & 0 & 7.54 & 1 & $2.44 \mathrm{E}-03$ & $2.44 \mathrm{E}-03$ & $\mathrm{~F}$ & 0. \\
\hline WNW & 580 & 0 & 5.46 & 1 & $1.66 \mathrm{E}-03$ & $1.66 \mathrm{E}-03$ & $\mathrm{~F}$ & \\
\hline $\mathrm{NW}$ & 580 & 0 & 4.92 & 1 & $1.56 \mathrm{E}-03$ & $1.56 \mathrm{E}-03$ & $G$ & 2.65 \\
\hline NNW & 580 & 0 & 3.41 & 1 & $7.89 \mathrm{E}-04$ & $7.89 \mathrm{E}-04$ & G & 4.70 \\
\hline N & 580 & 0 & 3.89 & 1 & $1.47 \mathrm{E}-03$ & $1.47 \mathrm{E}-03$ & & 2.65 \\
\hline NNE & 640 & 0 & 3.54 & 1 & $6.84 \mathrm{E}-04$ & $6.84 E-04$ & G & 4.70 \\
\hline $\mathrm{NE}$ & 860 & 0 & 5.96 & 1 & $8.48 \mathrm{E}-04$ & $8.48 \mathrm{E}-04$ & $\mathrm{~F}$ & 0.89 \\
\hline ENE & 2540 & 0 & 9.19 & $i$ & $2.47 \mathrm{E}-04$ & $2.47 \mathrm{E}-04$ & $\mathrm{~F}$ & 0.8 \\
\hline $\mathrm{E}$ & 11470 & 0 & 16.14 & $i$ & $4.73 E-05$ & 4.73E-05 & G & 0. \\
\hline ESE & 12060 & 0 & 10.16 & $i$ & 3.48 & 3.4 & $\mathrm{~F}$ & 0. \\
\hline $\mathrm{SE}$ & 15150 & 0 & 6.17 & $i$ & & & $\mathrm{~F}$ & 0.89 \\
\hline SSE & & 0 & 4.44 & 1 & $1.72 \mathrm{E}-05$ & $1.72 E-05$ & $F$ & 0.89 \\
\hline $\mathrm{s}$ & & 0 & 6.18 & 1 & $9.47 \mathrm{E}-06$ & $9.47 \mathrm{E}-06$ & $\mathrm{~F}$ & 0.8 \\
\hline SSW & 17130 & 0 & 5.01 & $i$ & $1.14 \mathrm{E}-05$ & $1.14 \mathrm{E}-05$ & G & 2.6 \\
\hline SW & 15510 & 0 & 3.91 & 1 & 1.4 & 1.4 & & 0.8 \\
\hline WSW & 11990 & 0 & 3.88 & 1 & & & $\mathrm{~F}$ & 0.8 \\
\hline$w$ & 10090 & 0 & 7.54 & 1 & & & $F$ & 0. \\
\hline WNW & 8740 & 0 & 5.46 & 1 & 3.0 & 3.0 & $\mathrm{~F}$ & 0. \\
\hline NW & 8740 & 0 & 4.92 & 1 & $2.84 \mathrm{E}-05$ & $2.84 \mathrm{E}-05$ & $G$ & 2. \\
\hline NNW & 8740 & 0 & 3.41 & 1 & 1.41 & 1.41 & & 4.70 \\
\hline & 8930 & 0 & 3.89 & 1 & & & G & 2.65 \\
\hline NNE & 10750 & 0 & 3. & 1 & 1.1 & 1.1 & G & 4.70 \\
\hline $\mathrm{NE}$ & 15 & 0 & 5.96 & 1 & & & & 0.89 \\
\hline ENE & & 0 & 9.19 & 1 & 1.6 & 1.6 & $\mathrm{~F}$ & 0.89 \\
\hline E & & 0 & 16.14 & $i$ & & 2.2 & & 0.89 \\
\hline ESE & & 0 & 10.16 & $i$ & $1.78 \mathrm{E}$ & & & 0.89 \\
\hline $\mathrm{SE}$ & & 0 & 6.17 & $i$ & $1.36 \mathrm{E}$ & & & 0.89 \\
\hline SSE & 24960 & 0 & 4.44 & 1 & $9.65 \mathrm{E}$ & 9.6 & & 0.2 \\
\hline & 12850 & 0 & 6.18 & 1 & $2.15 \mathrm{E}$ & & $\mathrm{F}$ & \\
\hline SSW & 11400 & 0 & 5.01 & 1 & & & & 2.65 \\
\hline SW & & 0 & 3. & 1 & & & & 0.89 \\
\hline WSW & & 0 & 3 & 1 & & & & $0 . \varepsilon$ \\
\hline W & & 0 & 7. & 1 & & 3. & & 0.8 \\
\hline WNW & 480 & 0 & 5.46 & 1 & $2.28 \mathrm{E}-03$ & $2.28 \mathrm{E}-03$ & & 0.89 \\
\hline $\mathrm{NW}$ & 480 & 0 & 4.92 & 1 & $2.15 \mathrm{E}-03$ & $2.15 \mathrm{E}-03$ & & $\begin{array}{l}0.09 \\
2.65\end{array}$ \\
\hline NNW & 480 & 0 & 3.41 & 1 & $1.08 \mathrm{E}$ & 1.0 & & 4.70 \\
\hline $\mathrm{N}$ & 480 & 0 & 3.89 & 1 & 2.02 & & & 2.65 \\
\hline NNE & 530 & 0 & 3.54 & 1 & 9.3 & & & 4.70 \\
\hline & 73 & 0 & 5. & 1 & & & & 0.89 \\
\hline $\mathrm{E}$ & 22 & 0 & 9. & $i$ & & & & 0.89 \\
\hline E & & J & 16. & $i$ & & & & 0.89 \\
\hline ESE & & 0 & 10. & 1 & 3.5 & $3.58 \mathrm{E}-05$ & & 0.89 \\
\hline SE & & 0 & 6.17 & $i$ & $2.14 E-05$ & $2.14 \mathrm{E}-05$ & & 0.89 \\
\hline SSE & $i$ & 0 & 4.44 & $i$ & $1.70 \mathrm{E}$ & $1.70 \mathrm{E}-05$ & & 0.89 \\
\hline s & 25150 & 0 & 6.18 & 1 & $9.38 \mathrm{E}$ & $9.38 \mathrm{E}-06$ & & $\begin{array}{l}0.09 \\
0.89\end{array}$ \\
\hline ssw & 17310 & 0 & 5.01 & $i$ & $1.12 \mathrm{E}-05$ & $1.12 \mathrm{E}-05$ & & 2.65 \\
\hline SW & 156 & 0 & 3. & $i$ & $1.38 \mathrm{E}-05$ & 1.388 & & \\
\hline 40 & & & & 8 & 2.0 & & & \\
\hline W & 100 & 0 & 7. & 1 & 4.4 & 4.4. & & 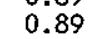 \\
\hline
\end{tabular}


HNF-SD-SNF-TI-059 REV 2

$\begin{array}{lrrrrrrrr}\text { WNW } & 8650 & 0 & 5.46 & 1 & 3.05 \mathrm{E}-05 & 3.05 \mathrm{E}-05 \mathrm{~F} & 0.89 \\ \text { NW } & 8650 & 0 & 4.92 & 1 & 2.88 \mathrm{E}-05 & 2.88 \mathrm{E}-05 \mathrm{G} & 2.65 \\ \text { NNW } & 8650 & 0 & 3.41 & 1 & 1.42 \mathrm{E}-05 & 1.42 \mathrm{E}-05 \mathrm{G} & 4.70 \\ \text { N } & 8810 & 0 & 3.89 & 1 & 2.65 \mathrm{E}-05 & 2.65 \mathrm{E}-05 \mathrm{G} & 2.65 \\ \text { NNE } & 10910 & 0 & 3.54 & 1 & 1.10 \mathrm{E}-05 & 1.10 \mathrm{E}-05 \mathrm{G} & 4.70 \\ \text { NE } & 15190 & 0 & 5.96 & 1 & 1.47 \mathrm{E}-05 & 1.47 \mathrm{E}-05 \mathrm{~F} & 0.89 \\ \text { ENE } & 19880 & 0 & 9.19 & 1 & 1.67 \mathrm{E}-05 & 1.67 \mathrm{E}-05 \mathrm{~F} & 0.89 \\ \mathrm{E} & 20380 & 0 & 16.14 & 1 & 2.31 \mathrm{E}-05 & 2.31 \mathrm{E}-05 \mathrm{G} & 0.89 \\ \text { ESE } & 20570 & 0 & 10.16 & 1 & 1.79 \mathrm{E}-05 & 1.79 \mathrm{E}-05 \mathrm{~F} & 0.89 \\ \text { SE } & 21700 & 0 & 6.17 & 1 & 1.36 \mathrm{E}-05 & 1.36 \mathrm{E}-05 \mathrm{~F} & 0.89 \\ \text { SSE } & 25150 & 0 & 4.44 & 1 & 9.57 \mathrm{E}-06 & 9.57 \mathrm{E}-06 \mathrm{~F} & 0.89\end{array}$


HNF-SD-SNF-TI-059 REV 2

GXQ Output for Release Durations $<1$ Hour

CSB - 99.5\%

GXQ Version 4.0

December 19, 1994

General Purpose Atmospheric Dispersion Code

Produced by West inghouse Hanford Company

Users Guide documented in WHC-SD-GN-SWD-30002 Rev. 1.

Val idation documented in WHC-SD-GN-SWD-30003 Rev. 1.

Code Custodian is: Brit E. Hey

West inghouse Hanford Company

P.0. Box 1970

Richland, WA 99352

(509) $376-2921$

Run Date $=04 / 09 / 99$

Run $\mathrm{Time}=14: 43: 34.14$

INPUT ECHO:

Acute -- Ground Level Release Height

c GXQ Version 4.0 Input File

c MODE SELECTION:

c 1 - X/Q based on Hanford site specific meteorology

2 - X/Q based on atmospheric stability $c$ lass and wind speed

3 - X/Q plot file is created

C SITE WIND \& POPULATION OPTIONS:

$c$ ifox inorm icdf ichk isite ipop

ifox $=t$ then joint frequency used to compute frequency-to-exceed $x / Q$

$=f$ then joint frequency used to compute annual average $X / Q$

inorm $=t$ then joint frequency data is normalized (as in GENII)

$=f$ then joint frequency data is un-normalized

$i c d f=t$ then cumulative distribution file created (CDF.OUT)

$=f$ then no cumulative distribution file created

$i c h k=t$ then $X / Q$ parameter print option turned on

$=f$ then no parameter print

isite $=t$ then $X / Q$ based on joint frequency data for all 16 sectors

$=f$ then $X / Q$ based on joint frequency data of individual sectors

ipop $=t$ then $X / Q$ is population weighted

$=f$ then no population weighting

c PUFF, DEPOSITION, \& WIND SPEED MODELS:

ipuff idep isrc iwind

$0 \begin{array}{lll}0 & 0 & 0\end{array}$

c DIFFUSION COEFFICIENT ADJUSTMENTS:

C iwake ipm iflow ientr

$\begin{array}{llll}0 & 0 & 0 & 0\end{array}$

c EFFECTIVE RELEASE HEIGHT ADJUSTMENTS:

c (irise igrnd) iwash igrav

$\begin{array}{llll}0 & 0 & 0 & 0\end{array}$

ipuff $=1$ then $X / Q$ calculated using puff model

$=0$ then $X / Q$ calculated using defaul $t$ continuous plume model

idep $=1$ then plume depletion model turned on (Chamberlain model)

isrc $=1$ then $X / Q$ multiplied by scalar

$=2$ then $X / Q$ adjusted by wind speed function

iwind $=1$ then wind speed corrected for plume height

i wake $=1$ then NRC RG 1.145 building wake model turned on

$=2$ then MACCS virtual distance building wake model turned on

$\mathrm{ipm}=1$ then NRC RG 1.145 plume meander model turned on

$=2$ then 5 th Power Law plume meander model turned on

$=3$ then sector average model turned on

iflow $=1$ then sigmas adjusted for volume flow rate

ientr $=1$ then method of Pasquill used to account for entrainment

irise $=1$ then MACCS buoyant plume rise model turned on

$=2$ then ISC2 momentum/buoyancy plume rise model turned on 


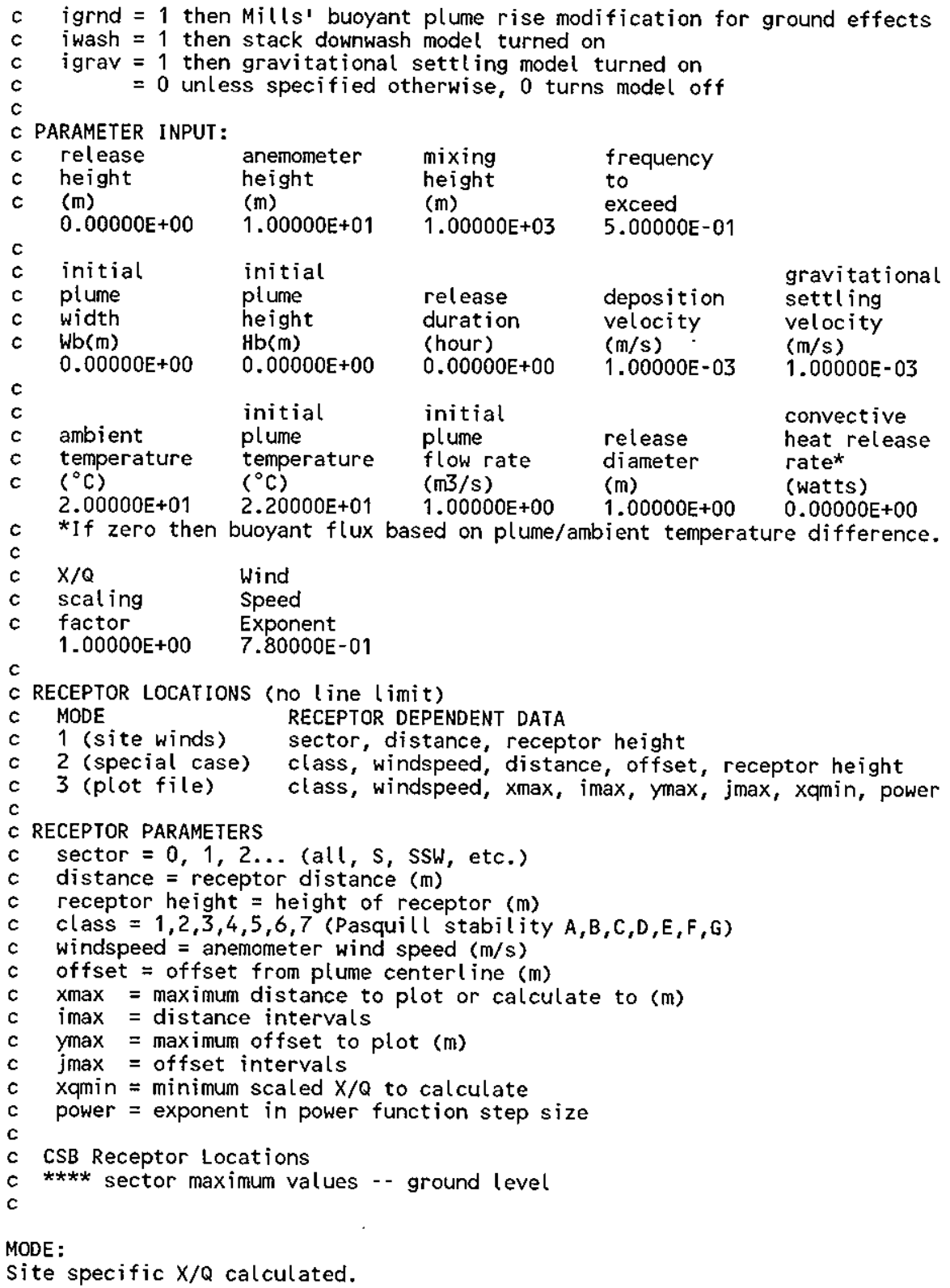

LOGICAL CHOICES:

Joint frequency used to calculate $X / Q$ based on frequency of exceedance. No normatization of joint frequency.

$X / Q$ calculated for single sector.

MODELS SELECTED:

Default Gaussian plume model selected.

WARNING/ERROR MESSAGES:

JOINT FREQUENCY DATA:

200 AREA (HMS) - $10 \mathrm{M}$ - Pasquill A - G (1983 - 1991 Average)

Created $8 / 26 / 92 \mathrm{KR}$

Acute -- Ground Level Release Height 


\begin{tabular}{|c|c|c|c|c|c|c|c|c|}
\hline SECTOR & $\begin{array}{l}\text { DISTANCE } \\
(\mathrm{m})\end{array}$ & $\begin{array}{c}\text { RECEPT } \\
\text { HEIGHT } \\
(\mathrm{m})\end{array}$ & $\begin{array}{c}\text { SECT. } \\
\text { FREQ. } \\
(\%)\end{array}$ & POPULATION & $\begin{array}{c}\text { TOTAL } \\
\text { POPULATION } \\
\text { SCALED } \\
X / Q \\
(\mathrm{~s} / \mathrm{m} 3)\end{array}$ & $\begin{array}{l}\text { AVERAGE } \\
\text { INDIVIDUAL } \\
\text { SCALED } \\
X / Q \\
(s / \mathrm{m} 3)\end{array}$ & $\begin{array}{l}\text { ATM. } \\
\text { STAB. } \\
\text { CLASS }\end{array}$ & $\begin{array}{l}\text { WIND } \\
\text { SPEED } \\
(\mathrm{m} / \mathrm{s})\end{array}$ \\
\hline 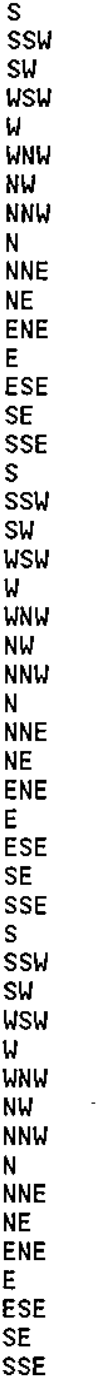 & $\begin{array}{r}100 \\
100 \\
100 \\
100 \\
100 \\
100 \\
100 \\
100 \\
100 \\
100 \\
100 \\
100 \\
100 \\
100 \\
100 \\
100 \\
7830 \\
7830 \\
7830 \\
7830 \\
9280 \\
10510 \\
11250 \\
11250 \\
11250 \\
12750 \\
12670 \\
12670 \\
12670 \\
14230 \\
11070 \\
8490 \\
16260 \\
16260 \\
16260 \\
17910 \\
18400 \\
18400 \\
18870 \\
19450 \\
19450 \\
20390 \\
17540 \\
17390 \\
17390 \\
17390 \\
20630 \\
18830\end{array}$ & $\begin{array}{l}0 \\
0 \\
0 \\
0 \\
0 \\
0 \\
0 \\
0 \\
0 \\
0 \\
0 \\
0 \\
0 \\
0 \\
0 \\
0 \\
0 \\
0 \\
0 \\
0 \\
0 \\
0 \\
0 \\
0 \\
0 \\
0 \\
0 \\
0 \\
0 \\
0 \\
0 \\
0 \\
0 \\
0 \\
0 \\
0 \\
0 \\
0 \\
0 \\
0 \\
0 \\
0 \\
0 \\
0 \\
0 \\
0 \\
0 \\
0\end{array}$ & $\begin{array}{r}6.30 \\
4.53 \\
2.93 \\
2.72 \\
4.80 \\
3.98 \\
4.72 \\
4.58 \\
4.36 \\
2.49 \\
3.90 \\
6.17 \\
14.05 \\
18.80 \\
10.83 \\
4.78 \\
6.30 \\
4.53 \\
2.93 \\
2.72 \\
4.80 \\
3.98 \\
4.72 \\
4.58 \\
4.36 \\
2.49 \\
3.90 \\
6.17 \\
14.05 \\
18.80 \\
10.83 \\
4.78 \\
6.30 \\
4.53 \\
2.93 \\
2.72 \\
4.80 \\
3.98 \\
4.72 \\
4.58 \\
4.36 \\
2.49 \\
3.90 \\
6.17 \\
14.05 \\
18.80 \\
10.83 \\
4.78\end{array}$ & $\begin{array}{l}1 \\
1 \\
1 \\
1 \\
1 \\
1 \\
1 \\
1 \\
1 \\
1 \\
1 \\
1 \\
1 \\
1 \\
1 \\
1 \\
1 \\
1 \\
1 \\
1 \\
1 \\
1 \\
1 \\
1 \\
1 \\
1 \\
1 \\
1 \\
1 \\
1 \\
1 \\
1 \\
1 \\
1 \\
1 \\
1 \\
1 \\
1 \\
1 \\
1 \\
1 \\
1 \\
1 \\
1 \\
1 \\
1 \\
1 \\
1\end{array}$ & $\begin{array}{l}1.56 \mathrm{E}-02 \\
1.13 \mathrm{E}-02 \\
1.21 \mathrm{E}-02 \\
1.22 \mathrm{E}-02 \\
2.80 \mathrm{E}-02 \\
1.60 \mathrm{E}-02 \\
2.89 \mathrm{E}-02 \\
2.90 \mathrm{E}-02 \\
3.12 \mathrm{E}-02 \\
1.54 \mathrm{E}-02 \\
1.57 \mathrm{E}-02 \\
2.52 \mathrm{E}-02 \\
3.41 \mathrm{E}-02 \\
3.25 \mathrm{E}-02 \\
3.07 \mathrm{E}-02 \\
1.58 \mathrm{E}-02 \\
1.57 \mathrm{E}-05 \\
9.66 \mathrm{E}-06 \\
1.25 \mathrm{E}-05 \\
1.25 \mathrm{E}-05 \\
2.36 \mathrm{E}-05 \\
1.14 \mathrm{E}-05 \\
1.91 \mathrm{E}-05 \\
1.92 \mathrm{E}-05 \\
2.06 \mathrm{E}-05 \\
7.96 \mathrm{E}-06 \\
8.50 \mathrm{E}-06 \\
1.44 \mathrm{E}-05 \\
1.92 \mathrm{E}-05 \\
1.59 \mathrm{E}-05 \\
2.07 \mathrm{E}-05 \\
1.44 \mathrm{E}-05 \\
6.05 \mathrm{E}-06 \\
3.83 \mathrm{E}-06 \\
4.91 \mathrm{E}-06 \\
4.36 \mathrm{E}-06 \\
9.97 \mathrm{E}-06 \\
5.59 \mathrm{E}-06 \\
1.00 \mathrm{E}-05 \\
9.70 \mathrm{E}-06 \\
1.04 \mathrm{E}-05 \\
4.31 \mathrm{E}-06 \\
5.60 \mathrm{E}-06 \\
9.69 \mathrm{E}-06 \\
1.30 \mathrm{E}-05 \\
1.24 \mathrm{E}-05 \\
9.51 \mathrm{E}-06 \\
5.16 \mathrm{E}-06\end{array}$ & $\begin{array}{l}1.56 \mathrm{E}-02 \\
1.13 \mathrm{E}-02 \\
1.21 \mathrm{E}-02 \\
1.22 \mathrm{E}-02 \\
2.80 \mathrm{E}-02 \\
1.60 \mathrm{E}-02 \\
2.89 \mathrm{E}-02 \\
2.90 \mathrm{E}-02 \\
3.12 \mathrm{E}-02 \\
1.54 \mathrm{E}-02 \\
1.57 \mathrm{E}-02 \\
2.52 \mathrm{E}-02 \\
3.41 \mathrm{E}-02 \\
3.25 \mathrm{E}-02 \\
3.07 \mathrm{E}-02 \\
1.58 \mathrm{E}-02 \\
1.57 \mathrm{E}-05 \\
9.66 \mathrm{E}-06 \\
1.25 \mathrm{E}-05 \\
1.25 \mathrm{E}-05 \\
2.36 \mathrm{E}-05 \\
1.14 \mathrm{E}-05 \\
1.91 \mathrm{E}-05 \\
1.92 \mathrm{E}-05 \\
2.06 \mathrm{E}-05 \\
7.96 \mathrm{E}-06 \\
8.50 \mathrm{E}-06 \\
1.44 \mathrm{E}-05 \\
1.92 \mathrm{E}-05 \\
1.59 \mathrm{E}-05 \\
2.07 \mathrm{E}-05 \\
1.44 \mathrm{E}-05 \\
6.05 \mathrm{E}-06 \\
3.83 \mathrm{E}-06 \\
4.91 \mathrm{E}-06 \\
4.36 \mathrm{E}-06 \\
9.97 \mathrm{E}-06 \\
5.59 \mathrm{E}-06 \\
1.00 \mathrm{E}-05 \\
9.70 \mathrm{E}-06 \\
1.04 \mathrm{E}-05 \\
4.31 \mathrm{E}-06 \\
5.60 \mathrm{E}-06 \\
9.69 \mathrm{E}-06 \\
1.30 \mathrm{E}-05 \\
1.24 \mathrm{E}-05 \\
9.51 \mathrm{E}-06 \\
5.16 \mathrm{E}-06\end{array}$ & $\begin{array}{l}E \\
F \\
F \\
F \\
G \\
G \\
G \\
G \\
G \\
E \\
E \\
G \\
F \\
F \\
G \\
G \\
E \\
F \\
F \\
F \\
G \\
G \\
G \\
G \\
G \\
E \\
E \\
G \\
F \\
F \\
G \\
G \\
E \\
F \\
F \\
F \\
G \\
G \\
G \\
G \\
G \\
E \\
E \\
G \\
F \\
F \\
G G \\
G\end{array}$ & $\begin{array}{l}0.89 \\
2.65 \\
2.65 \\
2.65 \\
2.65 \\
4.70 \\
2.65 \\
2.65 \\
2.65 \\
0.89 \\
0.89 \\
2.65 \\
0.89 \\
0.89 \\
2.65 \\
4.70 \\
0.89 \\
2.65 \\
2.65 \\
2.65 \\
2.65 \\
4.70 \\
2.65 \\
2.65 \\
2.65 \\
0.89 \\
0.89 \\
2.65 \\
0.89 \\
0.89 \\
2.65 \\
4.70 \\
0.89 \\
2.65 \\
2.65 \\
2.65 \\
2.65 \\
4.70 \\
2.65 \\
2.65 \\
2.65 \\
0.89 \\
0.89 \\
2.65 \\
0.89 \\
0.89 \\
2.65 \\
4.70\end{array}$ \\
\hline
\end{tabular}


GXQ Output for Release Durations $<1$ Hour

CVDF \& 100-KW - 95\% Overall Site

GXQ Version 4.0

Decemper 19, 1994

General Purpose Atmospheric Dispersion Code

Produced by Westinghouse Hanford Company

Users Guide documented in WHC-SD-GN-SWD-30002 Rev. 1.

Validation documented in WHC-SD-GN-SWD-30003 ReV. 1.

Code Custodian is: Brit E. Hey

Westinghouse Hanford Company

P.O. Box 1970

Richland, WA 99352

(509) $376-2921$

Run Date $=04 / 12 / 99$

Run $\mathrm{T}$ ime $=08: 26: 18.46$

INPUT ECHO:

Acute -- Ground Level Release Height

c GXQ Version 4.0 Input File

1

c MODE SELECTION:

1 - X/Q based on Hanford site specific meteorology

2 - $X / Q$ based on atmospheric stability class and wind speed

3 - X/Q plot file is created

C SITE WIND \& POPULATION OPTIONS:

C ifox inorm icdf ichk isite ipop

$i f o x=t$ then joint frequency used to compute frequency-to-exceed $x / Q$

$=f$ then joint frequency used to compute annual average $X / Q$

inorm $=t$ then joint frequency data is normalized (as in GENII)

$=f$ then joint frequency data is un-normalized

$i c d f=t$ then cumulative distribution file created (CDF.OUT)

$=f$ then no cumulative distribution file created

ichk $=t$ then $X / Q$ parameter print option turned on

$=f$ then no parameter print

isite $=t$ then $X / Q$ based on joint frequency data for all 16 sectors

$=f$ then $X / Q$ based on joint frequency data of individual sectors

ipop $=t$ then $X / Q$ is population weighted

$=f$ then no population weighting

c PUFF, DEPOSITION, \& WIND SPEED MODELS:

ipuff idep isre iwind

$\begin{array}{llll}0 & 0 & 0 & 0\end{array}$

c DIFFUSION COEFFICIENT ADJUSTMENTS:

c iwake ipm iflow ientr

0 O 0 O 0

c EFFECTIVE RELEASE HEIGHT ADJUSTMENTS:

C (irise igrnd) iwash igrav

$\begin{array}{llll}0 & 0 & 0 & 0\end{array}$

ipuff $=1$ then $X / Q$ calculated using puff model

$=0$ then $X / Q$ calculated using defaul $t$ cont inuous plume model

idep $=1$ then plume depletion model turned on (Chamberlain model)

isrc $=1$ then $X / Q$ multiplied by scalar

$=2$ then $X / Q$ adjusted by wind speed function

iwind $=1$ then wind speed corrected for plume height

iwake $=1$ then NRC RG 1.145 building wake model turned on

$=2$ then MACCS virtual distance building wake model turned on

$j \mathrm{pm}=1$ then NRC RG 1.145 plume meander model turned on

$=2$ then 5 th Power Law plume meander model turned on

$=3$ then sector average model turned on

iflow $=1$ then sigmas adjusted for volume flow rate

ientr $=1$ then method of Pasquill used to account for entrainment

irise $=1$ then MACCS buoyant plume rise model turned on

$=2$ then ISC2 momentum/buoyancy plume rise model turned on 


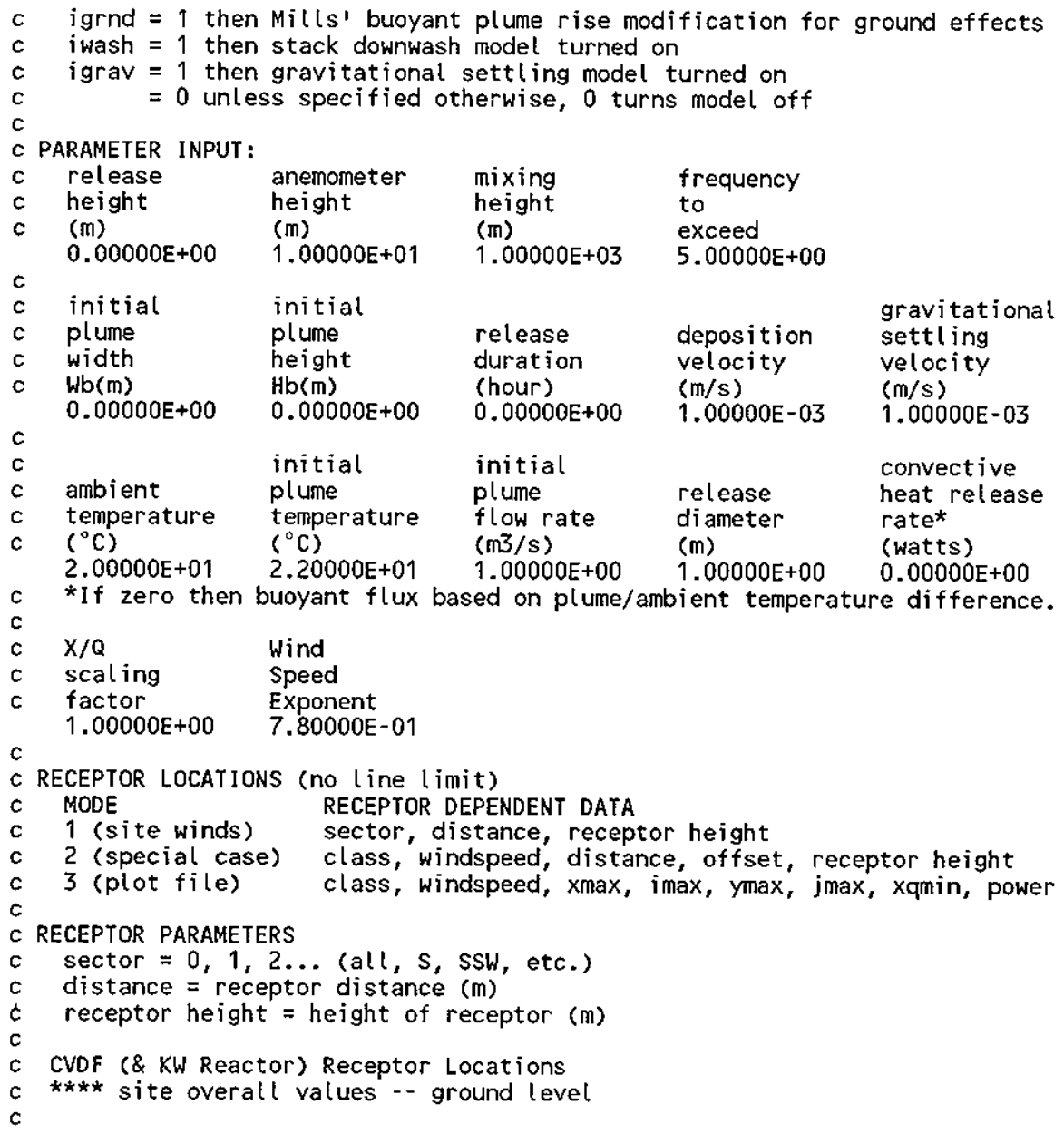

MODE:

Site specific $X / Q$ calculated.

LOGICAL CHOICES:

Joint frequency used to calculate $X / Q$ based on frequency of exceedance. No normalization of joint frequency.

$X / Q$ calculated for overall site.

MODELS SELECTED:

Default Gaussian plume model selected.

WARNING/ERROR MESSAGES:

JOINT FREQUENCY DATA:

$100 \mathrm{~N}$ AREA - $10 \mathrm{M}$ - Pasquill A - G (1983 - 1991 Average)

Created $8 / 26 / 92 \mathrm{KR}$

Acute -- Ground Level Release Height

\begin{tabular}{|c|c|c|c|c|c|c|c|c|}
\hline SECTOR & $\begin{array}{l}\text { DISTANCE } \\
\text { (m) }\end{array}$ & $\begin{array}{l}\text { RECEPT } \\
\text { HEI GHT } \\
\text { (m) }\end{array}$ & $\begin{array}{c}\text { SECT. } \\
\text { FREQ. } \\
(\%)\end{array}$ & POPULATION & $\begin{array}{l}\text { TOTAL } \\
\text { POPULATION } \\
\text { SCALED } \\
X / Q \\
(\mathrm{~s} / \mathrm{m} 3)\end{array}$ & $\begin{array}{l}\text { AVERAGE } \\
\text { INDIVIDUAL } \\
\text { SCALED } \\
X / Q \\
(\mathrm{~s} / \mathrm{m} 3)\end{array}$ & $\begin{array}{l}\text { ATM. } \\
\text { STAB. } \\
\text { CLASS }\end{array}$ & $\begin{array}{l}\text { WIND } \\
\text { SPEED } \\
(\mathrm{m} / \mathrm{s})\end{array}$ \\
\hline $\begin{array}{l}\overline{A L L} \\
A L L \\
A L L \\
A L L \\
A L L\end{array}$ & $\begin{array}{r}100 \\
100 \\
15600 \\
15600 \\
24960\end{array}$ & $\begin{array}{l}0 \\
0 \\
0 \\
0 \\
0\end{array}$ & $\begin{array}{l}99.80 \\
99.80 \\
99.80 \\
99.80 \\
99.80\end{array}$ & $\begin{array}{l}1 \\
1 \\
1 \\
1 \\
1\end{array}$ & $\begin{array}{l}6.10 \mathrm{E}-02 \\
3.44 \mathrm{E}-02 \\
1.22 \mathrm{E}-03 \\
1.22 \mathrm{E}-03 \\
2.62 \mathrm{E}-05\end{array}$ & $\begin{array}{l}6.10 \mathrm{E}-02 \\
3.44 \mathrm{E}-02 \\
1.22 \mathrm{E}-03 \\
1.22 \mathrm{E}-03 \\
2.62 \mathrm{E}-05\end{array}$ & $\begin{array}{l}G \\
F \\
G \\
G \\
G\end{array}$ & $\begin{array}{l}0.89 \\
0.89 \\
2.65 \\
2.65 \\
2.65\end{array}$ \\
\hline
\end{tabular}




\section{HNF-SD-SNF-TI-059 REV 2}

$\begin{array}{lllllllll}\text { ALL } & 24960 & 0 & 99.80 & 1 & 2.62 E-05 & 2.62 E-05 G & 2.65 \\ \text { ALL } & 15800 & 0 & 99.80 & 1 & 1.58 E-03 & 1.58 E-03 G & 0.89 \\ \text { ALL } & 15800 & 0 & 99.80 & 1 & 1.58 E-03 & 1.58 E-03 G & 0.89 \\ \text { ALL } & 25150 & 0 & 99.80 & 1 & 2.65 E-05 & 2.65 E-05 G & 2.65 \\ \text { ALL } & 25150 & 0 & 99.80 & 1 & 2.66 E-05 & 2.66 E-05 \text { G } & 2.65\end{array}$


GXQ Output for Release Durations $<1$ Hour

CSB -- 95\% Overall Site

GXQ Version 4.0

December 19, 1994

General Purpose Atmospheric Dispersion Code

Produced by Westinghouse Hanford Company

Users Guide documented in WHC-SD-GN-SWD-30002 Rev. 1.

Validation documented in WHC-SD-GN-SWD-30003 ReV. 1.

Code Custodian is: Brit E. Hey

West inghouse Hanford Company

P.O. Box 1970

Richland, WA 99352

(509) $376-2921$

Run Date $=04 / 12 / 99$

Run $\mathrm{T}$ ime $=08: 26: 29.56$

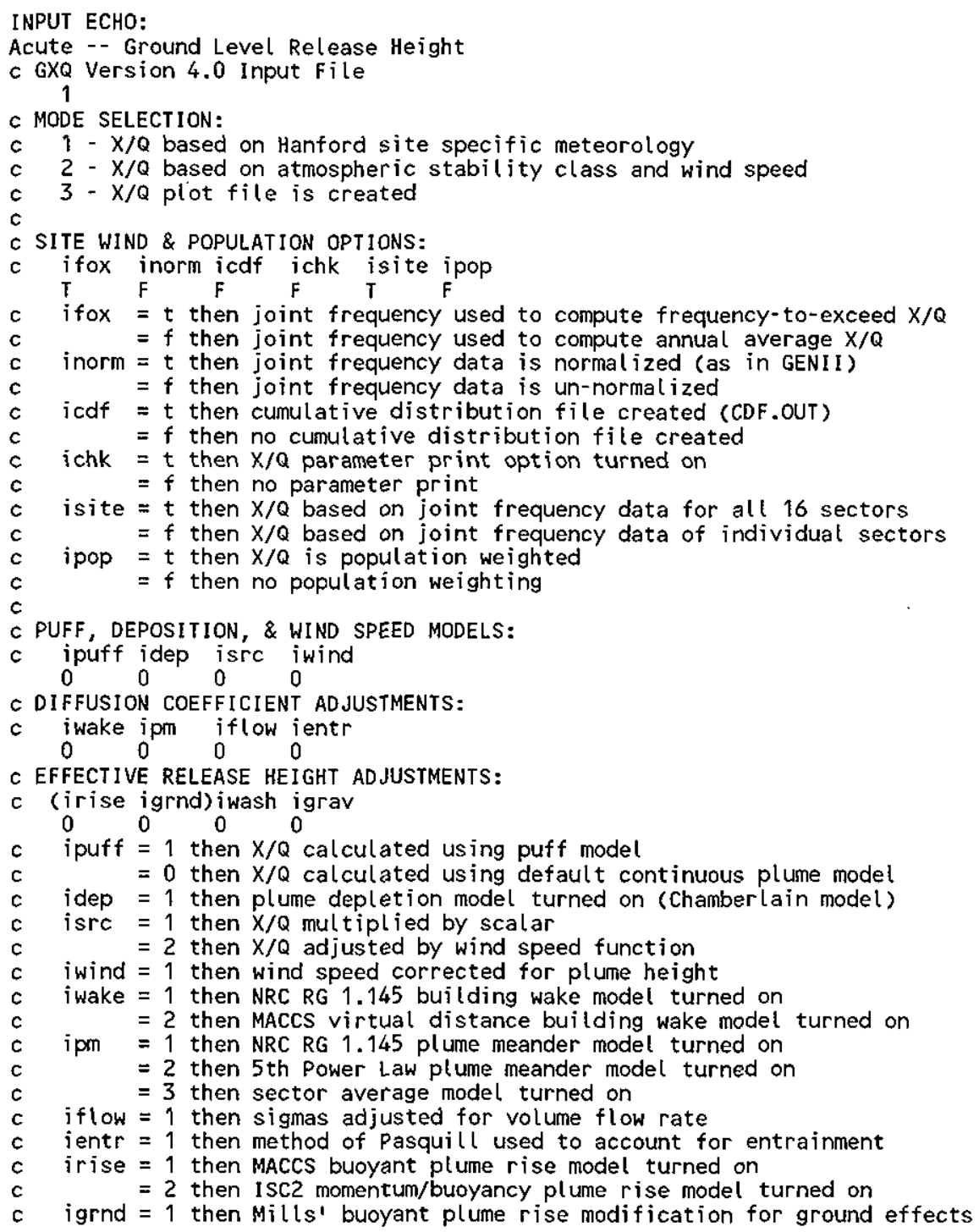






LOGICAL CHOICES:

Joint frequency used to calculate $X / Q$ based on frequency of exceedance.

No normalization of joint frequency.

$X / Q$ calculated for overall site.

MODELS SELECTED:

Default Gaussian plume model selected.

WARNING/ERROR MESSAGES:

JOINT FREQUENCY DATA :

200 AREA (HMS) - $10 \mathrm{M}$ - Pasquill A - G (1983 - 1991 Average)

created $8 / 26 / 92 \mathrm{KR}$

Acute - - Ground Level Release Height

\begin{tabular}{|c|c|c|c|c|c|c|c|c|}
\hline SECTOR & $\begin{array}{l}\text { DISTANCE } \\
(\mathrm{m})\end{array}$ & $\begin{array}{l}\text { RECEPT } \\
\text { HEI GHT } \\
(\mathrm{m})\end{array}$ & $\begin{array}{l}\text { SECT. } \\
\text { FREQ. } \\
(\%)\end{array}$ & POPULATION & $\begin{array}{c}\text { TOTAL } \\
\text { POPULATION } \\
\text { SCALED } \\
X / Q \\
(\mathrm{~s} / \mathrm{m} 3)\end{array}$ & $\begin{array}{l}\text { AVERAGE } \\
\text { IND IVIDUAL } \\
\text { SCALED } \\
X / Q \\
(\mathrm{~s} / \mathrm{m} 3)\end{array}$ & $\begin{array}{l}\text { ATM. } \\
\text { STAB. } \\
\text { CLASS }\end{array}$ & $\begin{array}{l}\text { WIND } \\
\text { SPEED } \\
(\mathrm{m} / \mathrm{s})\end{array}$ \\
\hline $\begin{array}{l}A L L \\
A L L \\
A L L \\
A L L \\
A L L \\
A L L\end{array}$ & $\begin{array}{r}100 \\
100 \\
8490 \\
8490 \\
18830 \\
18830\end{array}$ & $\begin{array}{l}0 \\
0 \\
0 \\
0 \\
0 \\
0\end{array}$ & $\begin{array}{l}99.94 \\
99.94 \\
99.94 \\
99.94 \\
99.94 \\
99.94\end{array}$ & $\begin{array}{l}1 \\
1 \\
1 \\
1 \\
1 \\
1\end{array}$ & $\begin{array}{l}3.28 \mathrm{E}-02 \\
3.44 \mathrm{E}-02 \\
2.02 \mathrm{E}-05 \\
2.02 \mathrm{E}-05 \\
1.16 \mathrm{E}-05 \\
1.16 \mathrm{E}-05\end{array}$ & $\begin{array}{l}3.28 \mathrm{E}-02 \\
3.44 \mathrm{E}-02 \\
2.02 \mathrm{E}-05 \\
2.02 \mathrm{E}-05 \\
1.16 \mathrm{E}-05 \\
1.16 \mathrm{E}-05\end{array}$ & $\begin{array}{l}F \\
F \\
G \\
G \\
F \\
F\end{array}$ & $\begin{array}{l}0.89 \\
0.89 \\
2.65 \\
2.65 \\
0.89 \\
0.89\end{array}$ \\
\hline
\end{tabular}




\section{GXQ Input for Release Durations from 1 Hour to 2 Hours}

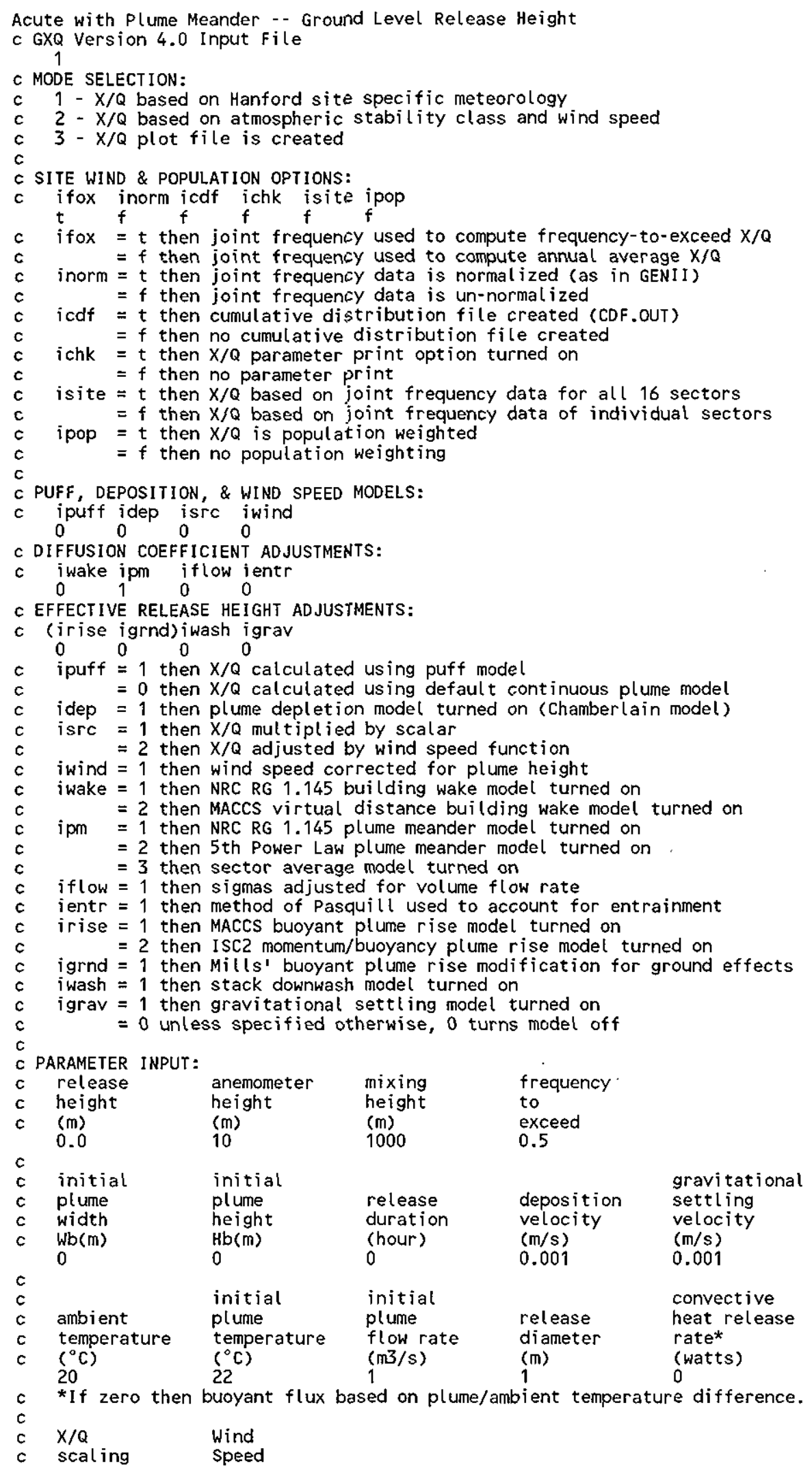




\section{HNF-SD-SNF-TI-059 REV 2}

c factor Exponent

$1 \quad .78$

c.

C RECEPTOR LOCATIONS (no line limit)

MODE RECEPTOR DEPENDENT DATA

1 (site winds) sector, distance, receptor height

2 (special case) class, windspeed, distance, of fset, receptor height

3 (plot file) class, windspeed, xmax, imax, ymax, jmax, xqmin, power

C RECEPTOR PARAMETERS

C sector $=0,1,2 \ldots($ all $, s, s s w$, etc. $)$

c distance $=$ receptor distance $(\mathrm{m})$

c receptor height $=$ height of receptor $(m)$

c class $=1,2,3,4,5,6,7$ (Pasquill stability $A, B, C, D, E, F, G$ )

$c \quad$ windspeed $=$ anemometer wind speed $(\mathrm{m} / \mathrm{s})$

c offset $=$ offset from plume centerline $(\mathrm{m})$

c $x$ max $=$ maximum distance to plot or calculate to (m)

c $\quad$ imax $=$ distance intervals

c $y$ max $=$ maximum offset to plot $(m)$

c $\quad j \max =$ offset intervals

c $\quad x q m i n=$ minimum scaled $X / Q$ to calculate

c power $=$ exponent in power function step size

Note: The GXQ input for overall site $X / Q$ is identical except that the "isite" $f$ lag is " $t$ " and the "frequency to exceed" is changed from 0.5 to 5.0 . 


\section{GXQ Input for Chronic Releases}

Chronic -- Ground Level Release Height

c GXQ Version 4.0 Input $F j l e$

1

c MODE SELECTION:

c 1 - X/Q based on Hanford site specific meteorology

c 2 - X/Q based on atmospheric stability class and wind speed

c 3 - X/Q plot file is created

c SITE WIND \& POPULATION OPTIONS:

$c$ ifox inorm icdf ichk isite ipop

ifox $=t$ then joint frequency used to compute frequency-to-exceed $X / Q$

$=f$ then joint frequency used to compute annual average $X / Q$

inorm $=t$ then joint frequency data is normalized (as in GENII)

$=f$ then joint frequency data is un-normalized

$i c d f=t$ then cumulative distribution file created (CDF.OUT)

$=f$ then no cumulative distribution file created

ichk $=t$ then $X / Q$ parameter print option turned on

$=f$ then no parameter print

isite $=t$ then $X / Q$ based on joint frequency data for all 16 sectors

$=f$ then $X / Q$ based on joint frequency data of individual sectors

ipop $=t$ then $X / Q$ is population weighted

$=f$ then no population weighting

PUFF, DEPOSITION, \& WIND SPEED MODELS:

ipuff idep isrc iwind

$\begin{array}{llll}0 & 0 & 0 & 0\end{array}$

c DIFFUSION COEFFICIENT ADJUSTMENTS:

C iwake ipm iflow ientr

0 3 30 O

c EFFECTIVE RELEASE HEIGHT ADJUSTMENTS:

c (irise igrnd)iwash igrav

0000000

ipuff $=1$ then $X / Q$ calculated using puff mlodel

$=0$ then $X / Q$ calculated using defaul $t$ continuous plume model

idep $=1$ then plume depletion model turned on (Chamberlain model)

isrc $=1$ then $X / Q$ multipl ied by scalar

$=2$ then $X / Q$ adjusted by wind speed function

iwind $=1$ then wind speed corrected for plume height

$i$ wake $=1$ then NRC RG 1.145 building wake model turned on

$=2$ then MACCS virtual distance building wake model turned on

ipm $=1$ then NRC RG 1.145 plume meander model turned on

$=2$ then 5 th Power Law plume meander model turned on

$=3$ then sector average model turned on

iflow $=1$ then sigmas adjusted for volume flow rate

ientr $=1$ then method of Pasquill used to account for entrainment

irise $=1$ then MACCS buoyant plume rise model turned on

$=2$ then ISC2 momentum/buoyancy plume rise model turned on

igrnd $=1$ then Mills' buoyant plume rise modification for ground effects

i wash $=1$ then stack downwash model turned on

igrav $=1$ then gravitational settling model turned on

$=0$ unless specified otherwise, 0 turns model off

PARAMETER INPUT:

release anemometer mixing frequency

$\begin{array}{lll}\text { release } & \text { anemometer mixing } & \text { height } \\ \text { height } & \text { height } & \text { to }\end{array}$

$\begin{array}{llll}(\mathrm{m}) & (\mathrm{m}) & (\mathrm{m}) & \text { exceed } \\ 0.0 & 10 & 1000 & 0.5\end{array}$

initial initial

plume plume

width height

$\begin{array}{ll}W b(m) & H b(m) \\ 0 & 0\end{array}$

0

$\begin{array}{ll}\begin{array}{l}\text { release } \\ \text { duration } \\ \text { (hour) }\end{array} & \begin{array}{l}\text { deposition } \\ \text { velocity } \\ \text { (m/s) }\end{array} \\ 0.001 \\ \text { initial } & \\ \text { plume } & \text { release } \\ \text { flow rate } & \text { diameter } \\ (\mathrm{m} 3 / \mathrm{s}) & (\mathrm{m})\end{array}$

gravitational settling velocity

$(\mathrm{m} / \mathrm{s})$

ambient

initial

ambient plume

temperature temperature

$\left({ }^{\circ} \mathrm{C}\right)$

$\left({ }^{\circ} \mathrm{C}\right)$

1

0.001

* If zero then buoyant flux based on plume/ambient temperature difference.

$\begin{array}{ll}X / Q & \text { Wind } \\ \text { scaling } & \text { Speed }\end{array}$ 


\section{HNF-SD-SNF-TI-059 REV 2}

factor Exponent

C

1.78

C RECEPTOR LOCATIONS (no line limit)

c MODE RECEPTOR DEPENDENT DATA

c 1 (site winds) sector, distance, receptor height

c 2 (special case) class, windspeed, distance, offset, receptor height

c 3 (plot $f i l e$ ) class, windspeed, xmax, imax, ymax, jmax, xqmin, power

C

C RECEPTOR PARAMETERS

C sector $=0,1,2 \ldots$ (all, s, ssw, etc.)

c distance $=$ receptor distance $(\mathrm{m})$

c receptor height $=$ height of receptor (m)

c class $=1,2,3,4,5,6,7$ (Pasquill stability $A, B, C, D, E, F, G$ )

c windspeed $=$ anemometer wind speed $(\mathrm{m} / \mathrm{s})$

c offset $=$ offset from plume centerline $(\mathrm{m})$

c $x \max =$ maximum distance to plot or calculate to (m)

c $i \max =$ distance intervals

c $y \max =\operatorname{maximum}$ offset to plot (m)

c $j \max =$ offset intervals

c $x q m i n=$ minimum scaled $X / Q$ to calculate

c power $=$ exponent in power function step size

Note: The GXQ input for overall site $X / Q$ is identical except that the "isite" $f$ lag is "t" and the "frequency to exceed" is changed from 0.5 to 5.0 . 


\section{GXQ Input for Puff Releases}

Acute Puff (1 sec) -- Ground Level Release Height

c GXQ Version 4.0 Input File

1

c MODE SELECTION:

c $1-X / Q$ based on Hanford site specific meteorology

c 2 - $X / Q$ based on atmospheric stability class and wind speed

c 3 - X/Q plot file is created

c SITE WIND \& POPULATION OPTIONS:

c ifox inorm icdf jchk isite ipop

$t$ f f f $f$ f f $f$

ifox $=t$ then joint frequency used to compute frequency-to-exceed $X / Q$

$=f$ then joint frequency used to compute annual average $X / Q$

inorm $=t$ then joint frequency data is normal ized (as in GENII)

$=f$ then joint frequency data is un-normalized

$i c d f=t$ then cumulative distribution file created (CDF.OUT)

$=f$ then no cumulative distribution file created

$i c h k=t$ then $X / Q$ parameter print option turned on

$=f$ then no parameter print

isite $=t$ then $X / Q$ based on joint frequency data for all 16 sectors

$=f$ then $X / Q$ based on joint frequency data of individual sectors

ipop $=t$ then $X / Q$ is population weighted

$=f$ then no population weighting

PUFF, DEPOSITION, \& WIND SPEED MODELS:

c ipuff idep isrc iwind

c DIFFUSION COEFFICIENT ADJUSTMENTS:

C iwake ipm iflow ientr

c EFFECTIVE RELEASE HEIGHT ADJUSTMENTS:

C (irise igrnd) iwash igrav

$\begin{array}{llll}0 & 0 & 0 & 0\end{array}$

ipuff $=1$ then $X / Q$ calculated using puff model

$=0$ then $X / Q$ calculated using defaul $t$ continuous plume model

idep $=1$ then plume depletion model turned on (Chamberlain model)

isrc $=1$ then $X / Q$ multiplied by scalar

$=2$ then $X / Q$ adjusted by wind speed function

iwind $=1$ then wind speed corrected for plume height

$i$ wake $=1$ then NRC RG 1.145 building wake model turned on

$=2$ then MACCS virtual distance building wake model turned on

ipm $=1$ then NRC RG 1.145 plume meander model turned on

$=2$ then 5 th Power Law plume meander model turned on

$=3$ then sector average model turned on

iflow $=1$ then sigmas adjusted for volume flow rate

ient $r=1$ then method of Pasquill used to account for entrainment

irise $=1$ then MACCS buoyant plume rise model turned on

$=2$ then ISC2 momentum/buoyancy plume $r$ ise model turned on

igrnd $=1$ then Mill's' buoyant plume rise modification for ground effects

iwash $=1$ then stack downwash model turned on

igrav $=1$ then gravitational settling model turned on

$=0$ unless specified otherwise, 0 turns model of $f$

C PARAMETER INPUT:

release anemometer mixing frequency

height height height to

$\begin{array}{llll}(\mathrm{m}) & (\mathrm{m}) & (\mathrm{m}) & \text { exceed } \\ 0.0 & 10 & 1000 & 0.5\end{array}$

c initial

plume

initial

width

$W b(m)$

plume

height

$\mathrm{Hb}(\mathrm{m})$

0

0

release

duration

(hour)

deposition

gravitational settling

velocity

(20)

2.7778E-4

velocity

(m/s)

$(\mathrm{m} / \mathrm{s})$

0.001

ambient plume

temperature temperature flow rate

$\left({ }^{\circ} \mathrm{C}\right) \quad\left({ }^{\circ} \mathrm{C}\right)$

$(\mathrm{m3} / \mathrm{s})$

0.001

convective

release heat release

*If zero then buoyant flux based on plume/ambient temperature difference.

rate*

(watts)

(m) 0

$X / Q \quad$ Wind

scaling speed 


\section{HNF-SD-SNF-TI-059 REV 2}

factor Exponent

C 1 .78

c RECEPTOR LOCATIONS (no line limit)

c MODE RECEPTOR DEPENDENT DATA

c 1 (site winds) sector, distance, receptor height

c 2 (special case) class, windspeed, distance, offset, receptor height

c 3 (plot file) class, windspeed, xmax, imax, ymax, jmax, xqmin, power

c RECEPTOR PARAMETERS

C sector $=0,1,2 \ldots$ (all, s, sSw, etc.)

c distance $=$ receptor distance $(\mathrm{m})$

c receptor height $=$ height of receptor (m)

c class $=1,2,3,4,5,6,7$ (Pasquil ( stability $A, B, C, D, E, F, G$ )

c $\quad$ windspeed $=$ anemometer wind speed $(\mathrm{m} / \mathrm{s})$

c offset $=$ offset from plume centerline (m)

c $x \max =$ maximum distance to plot or calculate to (m)

c $\quad$ imax = distance intervals

c $y \max =$ maximum offset to plot (m)

c $j \max =$ offset intervals

c $\quad x$ gmin $=$ minimum scaled $X / Q$ to calculate

c power $=$ exponent in power function step size

Note: The GXQ input for overall site $X / Q$ is identical except that the "isite" $f(a g$ is "t" and the "frequency to exceed" is changed from 0.5 to 5.0 . 


\section{GXQ Input for Receptor Locations}

c

CVDF (\& KW Reactor) Receptor Locations

**** sector maximum values -- ground level

100

3750

12650

11340

1690

700

650

580

580

580

640

2540

11470

12060

15150

15600

24960

17130

15510

11990

10090

8740

8740

8740

8930

10750

15390

20080

20510

20670

21790

24960

12850

11400

1060

710

520

480

480

480

480

530

730

2250

11330

11780

15050

15800

25150

17310

15660

12040

10070

8650

8650

8650

8810

10910

15190

19880

20380

20570

21700

100 meter

Fire Station

CVDF - - Near Bank of Columbia

River and Highway 240

CVDF - - Legal Boundary

100-KW -- Near Bank of Columbia

River and Highway 240

25150

100-KW -- Legal Boundary

CVDF (\& KW Reactor) Receptor Locations

***** site overall values -- ground level 


\section{HNF-SD-SNF-TI-059 REV 2}

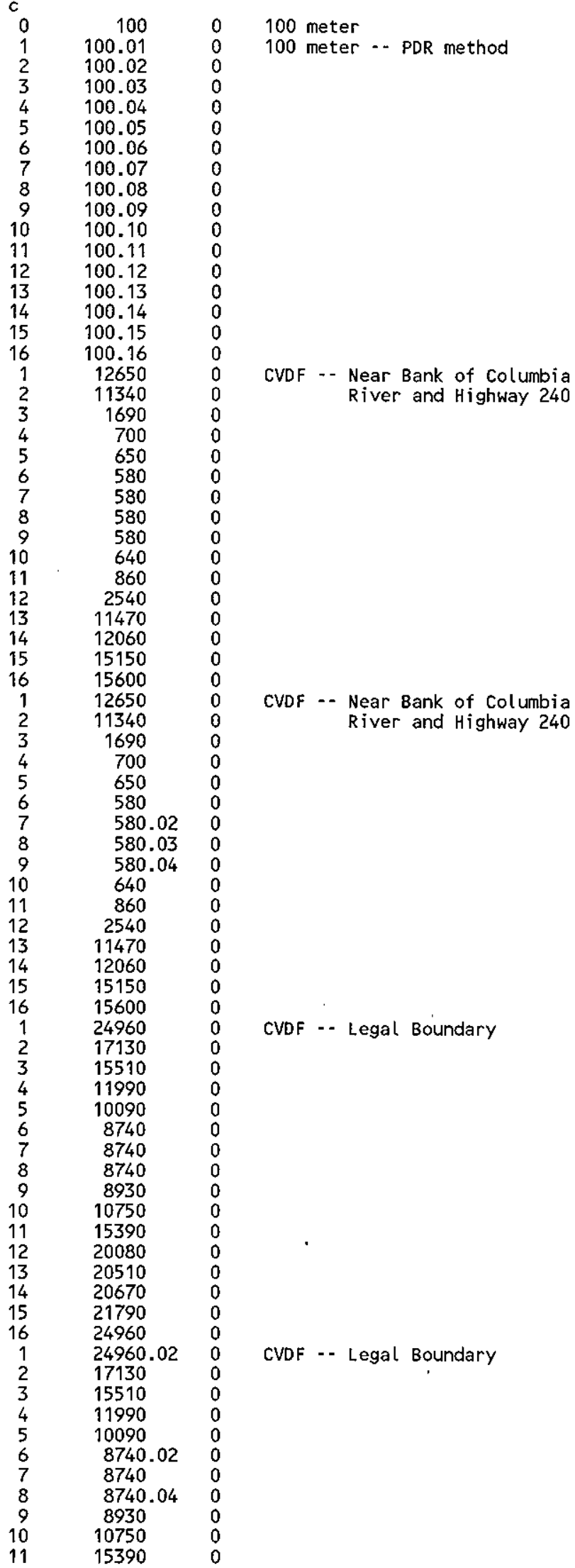


HNF-SD-SNF-TI-059 REV 2

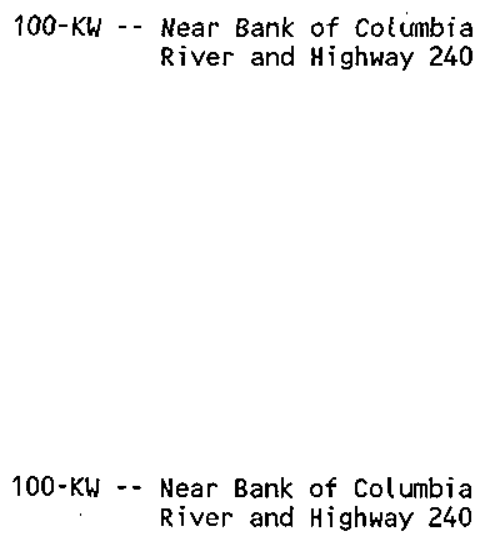


HNF-SD-SNF-TI-059 REV 2

$\begin{array}{rrr}3 & 7830 & 0 \\ 4 & 7830 & 0 \\ 5 & 9280 & 0 \\ 6 & 10510 & 0 \\ 7 & 11250 & 0 \\ 8 & 11250 & 0 \\ 9 & 11250 & 0 \\ 10 & 12750 & 0 \\ 11 & 12670 & 0 \\ 12 & 12670 & 0 \\ 13 & 12670 & 0 \\ 14 & 14230 & 0 \\ 15 & 11070 & 0 \\ 16 & 8490 & 0 \\ 1 & 16260 & 0 \\ 2 & 16260 & 0 \\ 3 & 16260 & 0 \\ 4 & 17910 & 0 \\ 5 & 18400 & 0 \\ 6 & 18400 & 0 \\ 7 & 18870 & 0 \\ 8 & 19450 & 0 \\ 9 & 19450 & 0 \\ 10 & 20390 & 0 \\ 11 & 17540 & 0 \\ 12 & 17390 & 0 \\ 13 & 17390 & 0 \\ 14 & 17390 & 0 \\ 15 & 20630 & 0 \\ 16 & 18830 & 0\end{array}$

CSB - L Legal Boundary

CSB Receptor Locations

**** site overall values -- ground level

100.01

100 meter

100.02

100 meter - - PDR method

100.03

100.04

100.05

100.06

100.07

100.08

100.09

100.10

100.11

100.12

100.13

100.14

100.15

100.16

7830

7830

7830

7830

9280

10510

11250

11250

11250

12750

12670

12670

12670

14230

11070

8490

7830.04

7830.03

7830.02

7830

9280

10510

11250.02

11250

11250.04

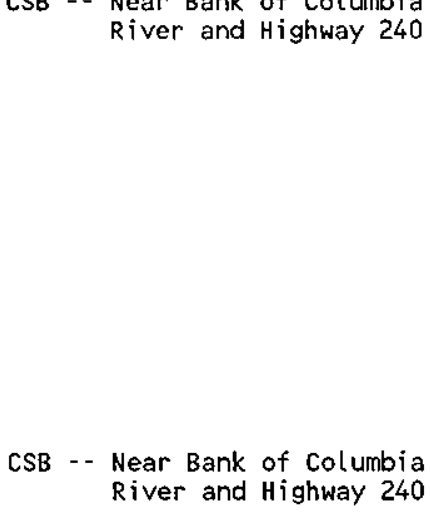


HNF-SD-SNF-TI-059 REV 2

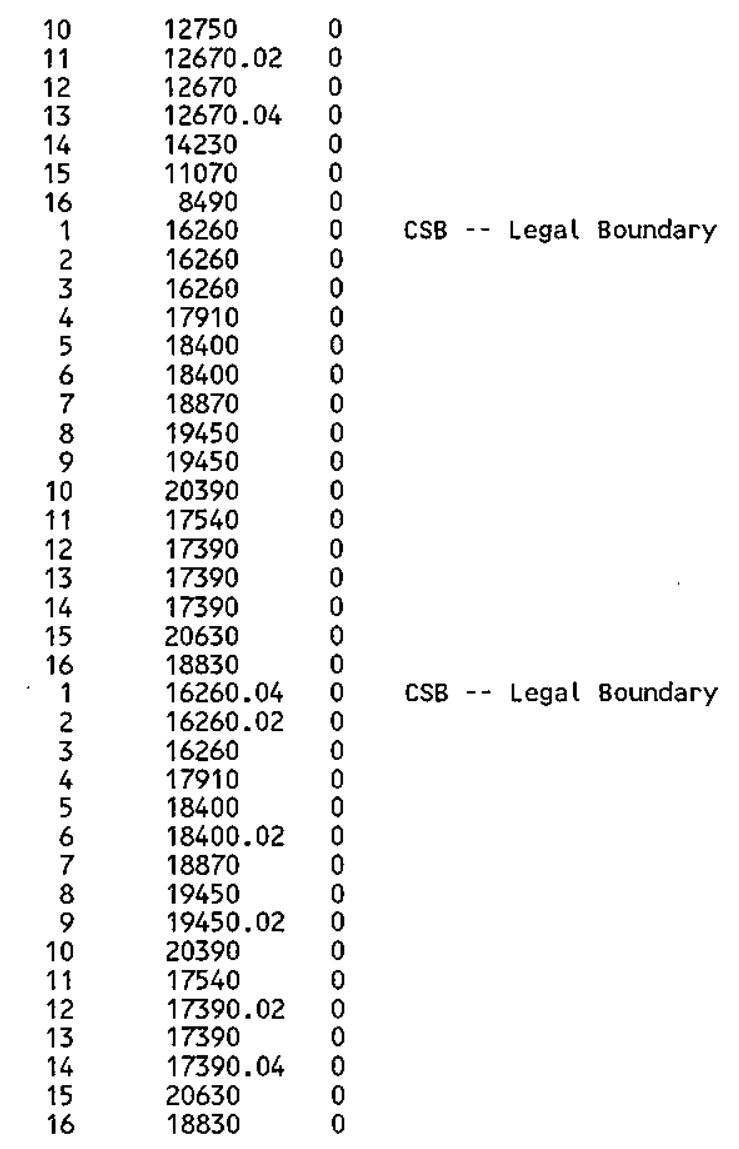




\section{DOS Batch File to Combine Distances with Ground-Level Release Input Files and Run GXQ}

aEcho off

: XQG.BAT by Paul D. Rittmann, PhD CHP

: Runs GXQ ground-level release cases for SNF

: Combines input file \& distance file first

: Specify which case to run on the command line

:START

Echo $[37 \mathrm{~m}$

IF $1 \% 1 "==" 1 "$ Goto OK-1

IF $1 \% 1 "==1 " 2 "$ Goto OK-2

Echo ${ }^{~}[36 \mathrm{~m}$

Echo Need to specify 100 or 200 Area cases on the command line. $[32 \mathrm{~m}$

Echo $\quad 1==$ run $\mathrm{CVDF} \& 100-\mathrm{KW}$ cases

Echo $2==$ run CSB cases $[36 \mathrm{~m}$

Echo Example: to run both cases type " $\left[\begin{array}{llll}33 m & \text { XQG } & 1 & 2\end{array}\right.$

Goto End

:OK-1

CD\GXQ

Call JFP $1.10 \mathrm{~B}$

CopY TI-059 XQ2\SS01.IN

Call RN SS01

Del SS01.IN

Goto $X Q$

$: 0 K-2$

$C D \backslash G X Q$

Call JFP $210 \mathrm{~B}$

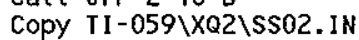

CopY TI-059 XQ2 \SS03.IN

Call RN SSO2 $\mathrm{SSO3}$

Del SS02.IN

Del SSO3.IN

$: X Q$

: first, the sector $X / Q$ calcs for $<1 \mathrm{~h}, 1 \mathrm{~h}-2 \mathrm{~h}$, chronic, and puff

For \%\%f in (A B C D) Do Copy TI-059 \XQ2 \GS\%\% . IN+TI-059 \XQ2\GS\%1.DST GS\%\% \%1. IN

Call RN GSA $\% 1$ GSB\%1 GSC\%1 GSD $\% 1$

Del GS?\%1.IN

: second, the overall site $X / Q$ calcs for $<1 \mathrm{~h}, 1 \mathrm{~h}-2 \mathrm{~h}$, chronic, and puff

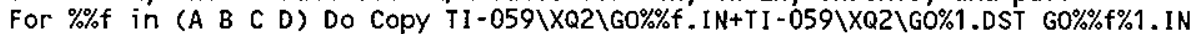

Call RN GOA\%1 GOB\%1 GOC\%1 GOD $\% 1$

Del GO?\%1.IN

Shift

IF not "\%1"=="" Goto START

:End

$\mathrm{PD} / 6$ 
HNF-SD-SNF-TI-059 REV 2

APPENDIX C

AIR TRANSPORT FACTORS FOR ELEVATED RELEASES 
HNF-SD-SNF-TI-059 REV 2

This page intentionally left blank. 


\section{APPENDIX C}

\section{AIR TRANSPORT FACTORS FOR ELEVATED RELEASES}

In the analysis of stack emissions from the Cold Vacuum Drying Facility (CVDF) and Canister Storage Building (CSB), it will be assumed that the main building is intact and causes wind eddies, which have two main effects. The first effect is to entrain the heating, ventilation, and air conditioning (HVAC) stack emissions and reduce the effective height of the release. The second effect is to dilute the emitted air near the point of release thereby reducing the air concentration at all downwind locations. Note that ground-level emissions were assumed to come from point sources with no building wake effects.

\section{Cold Vacuum Drying Facility Layout}

The HVAC emission stack for the CVDF is located about $4.57 \mathrm{~m}(15 \mathrm{ft})$ west of the building (based on the $100 \mathrm{~K}$ Area grid, which is rotated $27.3^{\circ}$ counterclockwise from true north). The CVDF stack is $14.63 \mathrm{~m}(48 \mathrm{ft})$ tall and $0.76 \mathrm{~m}$ (30 in.) in diameter. The expected flow rate from the stack is $8.33 \mathrm{~m}^{3} / \mathrm{s}\left(17,650 \mathrm{ft}^{3} / \mathrm{min}\right)$, so the linear exit speed of the gases is $18.3 \mathrm{~m} / \mathrm{s}(40.9 \mathrm{mi} / \mathrm{hr})$. This vertical jet will rise considerably because of its own momentum. The next section discusses the modeling of plume rise.

The CVDF itself is about $10.67 \mathrm{~m}(35 \mathrm{ft})$ tall. The building is $51.68 \mathrm{~m}(170 \mathrm{ft})$ in the northsouth direction (100 K grid) and $24.38 \mathrm{~m}(80 \mathrm{ft})$ in the east-west direction $(100 \mathrm{~K}$ grid). Because the process bay HVAC stack and the building are close together and about the same height, the building will have a significant effect on the projected downwind concentrations.

\section{Canister Storage Building Facility Layout}

The HVAC emission stack for the CSB is located about $8.53 \mathrm{~m}(28 \mathrm{ft})$ north of the building. The CSB stack is $22.86 \mathrm{~m}(75 \mathrm{ft})$ tall and $0.71 \mathrm{~m}(28 \mathrm{in}$.) in diameter. The expected flow rate from the stack is $2.12 \mathrm{~m}^{3} / \mathrm{s}\left(4,500 \mathrm{ft}^{3} / \mathrm{min}\right)$, so the linear exit speed of the gases is $5.35 \mathrm{~m} / \mathrm{s}(12.0 \mathrm{mi} / \mathrm{hr})$. This vertical jet will rise very little because of its own momentum. The next section discusses the modeling of plume rise.

The CSB itself is about $18.29 \mathrm{~m}(60 \mathrm{ft})$ tall. The building is $70.41 \mathrm{~m}(231 \mathrm{ft})$ in the northsouth direction and $42.37 \mathrm{~m}$ (139 ft) in the east-west direction. Because the HVAC stack and the building are close together and about the same height, the building will have a significant effect on the projected downwind concentrations.

The natural circulation emission stacks for the CSB are located on the east side of the building. These stacks are $47.55 \mathrm{~m}(156 \mathrm{ft})$ tall and $2.13 \mathrm{~m}(7 \mathrm{ft})$ in diameter at the top. The assumed flow rate from each stack is $3.8 \mathrm{~m}^{3} / \mathrm{s}\left(8,000 \mathrm{ft}^{3} / \mathrm{min}\right)$, so the linear exit speed of the gases is $1.06 \mathrm{~m} / \mathrm{s}(2.4 \mathrm{mi} / \mathrm{hr})$. This vertical jet will rise very little because of its own momentum. The stack is more than 2.5 times the height of the CSB, so it will be modeled as a free stack. 
The proximity of the CSB will normally have no influence on the air concentrations downwind. The factor of 2.5 comes from various NRC Regulatory Guides (e.g., NRC Regulatory Guide 1.145).

\section{Modeling Plume Rise}

The industrial source complex plume rise model found in the GXQ computer code (WHC-SD-GN-SWD-30002, WHC-SD-GN-SWD-30003) is used for the Spent Nuclear Fuel Project facility stacks described above. To be conservative, only momentum effects and stack downwash effects are considered. It is assumed that the temperature of the exhaust air is the same as the air temperature at the top of the stack, so buoyant effects are not included. The tables below show the GXQ results for the height the plume rises above the top of the stack, the total final height of the plume, and the effective wind speed at the final height. The GXQ program adjusts the wind speed as the plume rises in a manner similar to the MACCS software (WHC-SD-GN-SWD-30002, NUREG/CR-4691).

Tables C-1, C-2, and C-3 show the expected plume rise and elevated wind speeds for CVDF and CSB emissions using the GXQ software (WHC-SD-GN-SWD-30002). Note that the negative plume rise values for the CSB are due to stack downwash exceeding the plume rise. To approximate the expected plume rise for the fumigation model, the average effective plume height for the stable categories (class E, F, and G) was determined. For CVDF this was $31 \mathrm{~m}$. For CSB it was $30 \mathrm{~m}$ (HVAC) and $48 \mathrm{~m}$ (natural circulation).

\section{Air Transport Factors}

The GXQ program (WHC-SD-GN-SWD-30002) has been used to calculate air transport factors. The methods described in Section 4.0 of this document were used. Sample input files are contained in Appendixes E. The air transport factors were calculated for all 16 wind transport directions to identify the worst direction (sector maximum 99.5\%). The overall site (95\%) air transport factor was also computed. In addition, the air transport factors were calculated at 100 , $150,200,250,300,350,400,450,500,550$, and $600 \mathrm{~m}$ for the onsite worker to ensure that the worst-case distance was identified. Resulting air transport factors for each wind transport direction are shown in Tables C-4 through C-12. The worst-case results are shown in Table 2 of this document. Note that in all cases the receptor height was increased to $2 \mathrm{~m}$. This increase represents the receptor being in a standing position. In most cases, this receptor height increases the air transport factor. In all cases, the effect of changing the release height from zero meters to $2 \mathrm{~m}$ is very small. 


\section{REFERENCES}

NRC Regulatory Guide 1.145, 1982, Atmospheric Dispersion Models for Potential Accident Consequence Assessments at Nuclear Power Plants, U.S. Nuclear Regulatory Commission, Washington, D.C.

NUREG/CR-4691 (SAND86-1562), 1990, MELCOR Accident Consequence Code System (MACCS), Sandia National Laboratories, Albuquerque, New Mexico.

WHC-SD-GN-SWD-30002, 1993, GXQ Program Users' Guide, Rev. 0, Westinghouse Hanford Company, Richland, Washington.

WHC-SD-GN-SWD-30003, 1993, GXQ Program Verification and Validation, Rev. 0, Westinghouse Hanford Company, Richland, Washington. 
HNF-SD-SNF-TI-059 REV 2

This page intentionally left blank. 
Table C-1. Plume Rise for the Cold Vacuum Drying Facility 48-Foot Heating, Ventilation, and Air Conditioning Stack.

\begin{tabular}{|c|c|c|c|c|c|}
\hline \multirow{2}{*}{$\begin{array}{c}\text { Stability } \\
\text { class }\end{array}$} & \multicolumn{5}{|c|}{ Wind speed $(\mathrm{m} / \mathrm{s})$ at $10-\mathrm{m}$ elevation } \\
\hline & 0.89 & 2.65 & 4.70 & 7.15 & 9.80 \\
\hline \multicolumn{6}{|c|}{ Plume rise $(\mathrm{m})$ due to exhaust momentum. } \\
\hline A & 43.48 & 14.95 & 8.51 & 5.62 & 4.11 \\
\hline B & 43.48 & 14.95 & 8.51 & 5.62 & 4.11 \\
\hline $\mathrm{C}$ & 42.12 & 14.64 & 8.35 & 5.53 & 4.05 \\
\hline $\mathrm{D}$ & 39.98 & 14.13 & 8.09 & 5.38 & 3.95 \\
\hline $\mathrm{E}$ & 18.38 & 12.34 & 7.24 & 4.86 & 3.56 \\
\hline $\mathrm{F}$ & 15.05 & 10.64 & 6.50 & 4.40 & 3.27 \\
\hline G & 13.40 & 9.47 & 6.34 & 4.30 & \\
\hline \multicolumn{6}{|c|}{ Final plume height $(\mathrm{m})$} \\
\hline A & 58.11 & 29.58 & 23.14 & 20.25 & 18.74 \\
\hline B & 58.11 & 29.58 & 23.14 & 20.25 & 18.74 \\
\hline $\mathrm{C}$ & 56.75 & 29.27 & 22.98 & 20.16 & 18.68 \\
\hline $\mathrm{D}$ & 54.61 & 28.76 & 22.72 & 20.01 & 18.58 \\
\hline E & 33.01 & 26.97 & 21.87 & 19.49 & 18.19 \\
\hline $\mathrm{F}$ & 29.69 & 25.27 & 21.13 & 19.03 & 17.90 \\
\hline G & 28.03 & 24.11 & 20.97 & 18.93 & \\
\hline $\begin{array}{c}\text { Stable } \\
\text { average }\end{array}$ & 30.2 & 25.4 & 21.3 & 19.1 & 18.0 \\
\hline \multicolumn{6}{|c|}{ Wind speed $(\mathrm{m} / \mathrm{s})$ at the plume height } \\
\hline A & 0.96 & 2.79 & 4.91 & 7.43 & 10.15 \\
\hline B & 0.96 & 2.79 & 4.91 & 7.43 & 10.15 \\
\hline $\mathrm{C}$ & 0.99 & 2.85 & 5.00 & 7.55 & 10.31 \\
\hline D & 1.05 & 2.96 & 5.15 & 7.75 & 10.56 \\
\hline$E$ & 1.18 & 3.39 & 5.78 & 8.60 & 11.64 \\
\hline $\mathrm{F}$ & 1.36 & 3.84 & 6.44 & 9.50 & 12.79 \\
\hline G & 1.38 & 3.91 & 6.62 & 9.73 & \\
\hline
\end{tabular}

Note: The above values were computed by the GXQ computer code using the industrial source complex momentum rise model with the MACCS plume rise/wind speed adjustment. The CVDF HVAC stack height and diameter are $48 \mathrm{ft}$ and $30 \mathrm{in}$., and the exhaust flow rate is $17,650 \mathrm{ft}^{3} / \mathrm{min}$. 
Table C-2. Plume Rise for the Canister Storage Building 75-Foot Heating, Ventilation, and Air Conditioning Stack.

\begin{tabular}{|c|c|c|c|c|c|}
\hline \multirow{2}{*}{$\begin{array}{l}\text { Stability } \\
\text { class }\end{array}$} & \multicolumn{5}{|c|}{ Wind speed $(\mathrm{m} / \mathrm{s})$ at $10-\mathrm{m}$ elevation } \\
\hline & 0.89 & 2.65 & 4.70 & 7.15 & 9.80 \\
\hline \multicolumn{6}{|c|}{ Plume rise $(\mathrm{m})$ due to exhaust momentum } \\
\hline A & 11.91 & 4.04 & 1.68 & 0.47 & -0.23 \\
\hline $\mathrm{B}$ & 11.91 & 4.04 & 1.68 & 0.47 & -0.23 \\
\hline $\mathrm{C}$ & 11.56 & 3.93 & 1.59 & 0.44 & -0.25 \\
\hline $\mathrm{D}$ & 10.99 & 3.75 & 1.43 & 0.40 & -0.28 \\
\hline $\mathrm{E}$ & 7.58 & 3.15 & 0.88 & 0.26 & -0.39 \\
\hline $\mathrm{F}$ & 6.13 & 2.35 & 0.41 & 0.14 & \\
\hline $\mathrm{G}$ & 5.42 & 2.17 & 0.31 & & \\
\hline \multicolumn{6}{|c|}{ Final plume height (m) } \\
\hline A & 34.77 & 26.90 & 24.54 & 23.33 & 22.63 \\
\hline B & 34.77 & 26.90 & 24.54 & 23.33 & 22.63 \\
\hline $\mathrm{C}$ & 34.42 & 26.79 & 24.45 & 23.30 & 22.61 \\
\hline $\mathrm{D}$ & 33.85 & 26.61 & 24.29 & 23.26 & 22.58 \\
\hline $\mathrm{E}$ & 30.44 & 26.01 & 23.74 & 23.12 & 22.47 \\
\hline $\mathrm{F}$ & 28.99 & 25.21 & 23.27 & 23.00 & \\
\hline G & 28.28 & 25.03 & 23.17 & & \\
\hline $\begin{array}{c}\text { Stable } \\
\text { average }\end{array}$ & 29.2 & 25.4 & 23.4 & 15.4 & 11.2 \\
\hline \multicolumn{6}{|c|}{ Wind wpeed $(\mathrm{m} / \mathrm{s})$ at the plume height } \\
\hline A & 0.96 & 2.82 & 4.99 & 7.58 & 10.38 \\
\hline B & 0.96 & 2.82 & 4.99 & 7.58 & 10.38 \\
\hline $\mathrm{C}$ & 0.99 & 2.90 & 5.12 & 7.77 & 10.64 \\
\hline $\mathrm{D}$ & 1.04 & 3.03 & 5.34 & 8.10 & 11.08 \\
\hline$E$ & 1.25 & 3.62 & 6.32 & 9.57 & 13.05 \\
\hline $\mathrm{F}$ & 1.50 & 4.29 & 7.44 & 11.29 & \\
\hline $\mathrm{G}$ & 1.56 & 4.47 & 7.75 & & \\
\hline
\end{tabular}

Note: The above values were computed by the GXQ computer code using the industrial source complex momentum rise model with the MACCS plume rise/wind speed adjustment. The CSB HVAC stack height and diameter are $75 \mathrm{ft}$ and $28 \mathrm{in}$., and the exhaust flow rate is $4,500 \mathrm{ft}^{3} / \mathrm{min}$. 
Table C-3. Plume Rise for the Canister Storage Building 156-Foot Natural Circulation Stack.

\begin{tabular}{|c|c|c|c|c|c|}
\hline \multirow{2}{*}{$\begin{array}{c}\text { Stability } \\
\text { class }\end{array}$} & \multicolumn{5}{|c|}{ Wind speed $(\mathrm{m} / \mathrm{s})$ at $10-\mathrm{m}$ elevation } \\
\hline & 0.89 & 2.65 & 4.70 & 7.15 & 9.80 \\
\hline \multicolumn{6}{|c|}{ Plume rise $(\mathrm{m})$ due to exhaust momentum } \\
\hline A & 4.36 & -3.20 & -4.73 & -5.36 & -5.67 \\
\hline B & 4.36 & -3.20 & -4.73 & -5.36 & -5.67 \\
\hline $\mathrm{C}$ & 3.83 & -3.37 & -4.81 & -5.41 & -5.71 \\
\hline $\mathrm{D}$ & 2.98 & -3.62 & -4.95 & -5.49 & -5.76 \\
\hline $\mathrm{E}$ & -0.17 & -4.45 & -5.37 & -5.76 & -5.95 \\
\hline $\mathrm{F}$ & 0.22 & -5.02 & -5.67 & -5.94 & \\
\hline $\mathrm{G}$ & -0.40 & -5.15 & -5.73 & & \\
\hline \multicolumn{6}{|c|}{ Final plume height $(\mathrm{m})$} \\
\hline A & 51.91 & 44.35 & 42.82 & 42.19 & 41.88 \\
\hline $\mathrm{B}$ & 51.91 & 44.35 & 42.82 & 42.19 & 41.88 \\
\hline $\mathrm{C}$ & 51.37 & 44.18 & 42.74 & 42.14 & 41.84 \\
\hline D & 50.53 & 43.93 & 42.60 & 42.06 & 41.79 \\
\hline $\mathrm{E}$ & 47.38 & 43.10 & 42.18 & 41.79 & 41.60 \\
\hline $\mathrm{F}$ & 47.77 & 42.53 & 41.88 & 41.61 & \\
\hline $\mathrm{G}$ & 47.15 & 42.40 & 41.82 & & \\
\hline $\begin{array}{c}\text { Stable } \\
\text { average }\end{array}$ & 47.4 & 42.7 & 42.0 & 27.8 & 20.8 \\
\hline \multicolumn{6}{|c|}{ Wind speed $(\mathrm{m} / \mathrm{s})$ at the plume height } \\
\hline A & 1.00 & 2.95 & 5.22 & 7.94 & 10.88 \\
\hline $\mathrm{B}$ & 1.00 & 2.95 & 5.22 & 7.94 & 10.88 \\
\hline $\mathrm{C}$ & 1.04 & 3.09 & 5.46 & 8.31 & 11.38 \\
\hline $\mathrm{D}$ & 1.13 & 3.33 & 5.89 & 8.95 & 12.26 \\
\hline $\mathrm{E}$ & 1.54 & 4.50 & 7.94 & 12.07 & 16.53 \\
\hline $\mathrm{F}$ & 2.10 & 6.06 & 10.71 & 16.26 & \\
\hline $\mathrm{G}$ & 2.26 & 6.53 & 11.53 & & \\
\hline
\end{tabular}

Note: The above values were computed by the GXQ computer code using the industrial source complex momentum rise model with the MACCS plume rise/wind speed adjustment. The Canister Storage Building natural circulation stack height and diameter are $156 \mathrm{ft}$ and $7 \mathrm{ft}$, and the exhaust flow rate is assumed to be $8,000 \mathrm{ft}^{3} / \mathrm{min}$. 
Table C-4. Air Transport Factors for Releases from the Cold Vacuum Drying Facility's Heating, Ventilation, and Air Conditioning Stack (48 Feet) to Onsite Workers.

\begin{tabular}{|c|c|c|c|c|}
\hline \multirow{2}{*}{$\begin{array}{c}\text { Transport } \\
\text { direction }\end{array}$} & \multicolumn{4}{|c|}{ Air transport factors, s/m $\mathrm{m}^{3}$} \\
\cline { 2 - 5 } & Fumigation & $<0.5 \mathrm{hr}$ & 0.5 to $2 \mathrm{hr}$ & Annual \\
\hline S & $5.07 \mathrm{E}-03$ & $5.11 \mathrm{E}-04$ & $6.73 \mathrm{E}-04$ & $1.65 \mathrm{E}-05$ \\
\hline SSW & $4.05 \mathrm{E}-03$ & $4.47 \mathrm{E}-04$ & $3.71 \mathrm{E}-04$ & $1.06 \mathrm{E}-05$ \\
\hline SW & $4.40 \mathrm{E}-03$ & $4.44 \mathrm{E}-04$ & $3.71 \mathrm{E}-04$ & $9.69 \mathrm{E}-06$ \\
\hline WSW & $4.67 \mathrm{E}-03$ & $4.52 \mathrm{E}-04$ & $3.82 \mathrm{E}-04$ & $9.54 \mathrm{E}-06$ \\
\hline W & $6.14 \mathrm{E}-03$ & $5.41 \mathrm{E}-04$ & $6.63 \mathrm{E}-04$ & $1.97 \mathrm{E}-05$ \\
\hline WNW & $4.67 \mathrm{E}-03$ & $5.31 \mathrm{E}-04$ & $5.82 \mathrm{E}-04$ & $1.58 \mathrm{E}-05$ \\
\hline NW & $4.37 \mathrm{E}-03$ & $5.08 \mathrm{E}-04$ & $5.13 \mathrm{E}-04$ & $1.35 \mathrm{E}-05$ \\
\hline NNW & $3.60 \mathrm{E}-03$ & $4.71 \mathrm{E}-04$ & $4.02 \mathrm{E}-04$ & $9.94 \mathrm{E}-06$ \\
\hline N & $4.22 \mathrm{E}-03$ & $5.15 \mathrm{E}-04$ & $5.40 \mathrm{E}-04$ & $1.25 \mathrm{E}-05$ \\
\hline NNE & $3.82 \mathrm{E}-03$ & $4.66 \mathrm{E}-04$ & $3.75 \mathrm{E}-04$ & $9.34 \mathrm{E}-06$ \\
\hline NE & $4.56 \mathrm{E}-03$ & $4.86 \mathrm{E}-04$ & $4.46 \mathrm{E}-04$ & $1.30 \mathrm{E}-05$ \\
\hline ENE & $5.75 \mathrm{E}-03$ & $4.84 \mathrm{E}-04$ & $5.13 \mathrm{E}-04$ & $1.72 \mathrm{E}-05$ \\
\hline E & $6.88 \mathrm{E}-03$ & $5.32 \mathrm{E}-04$ & $6.66 \mathrm{E}-04$ & $2.76 \mathrm{E}-05$ \\
\hline ESE & $6.06 \mathrm{E}-03$ & $4.98 \mathrm{E}-04$ & $6.28 \mathrm{E}-04$ & $1.88 \mathrm{E}-05$ \\
\hline SE & $5.50 \mathrm{E}-03$ & $4.95 \mathrm{E}-04$ & $6.42 \mathrm{E}-04$ & $1.51 \mathrm{E}-05$ \\
\hline SSE & $5.11 \mathrm{E}-03$ & $4.84 \mathrm{E}-04$ & $6.04 \mathrm{E}-04$ & $1.29 \mathrm{E}-05$ \\
\hline Sector Maximum & $6.88 \mathrm{E}-03$ & $5.41 \mathrm{E}-04$ & $6.73 \mathrm{E}-04$ & $2.76 \mathrm{E}-05$ \\
$(99.5 \%)$ & $100 \mathrm{mE}$ & $250 \mathrm{~m}$ W & $100 \mathrm{~m}$ S & $150 \mathrm{~m} \mathrm{E}$ \\
\hline Overall Site & $6.24 \mathrm{E}-03$ & $5.41 \mathrm{E}-04$ & $6.98 \mathrm{E}-04$ & $1.45 \mathrm{E}-05$ \\
$(95 \%)$ & $100 \mathrm{~m}$ & $250 \mathrm{~m}$ & $100 \mathrm{~m}$ & $150 \mathrm{~m}$ \\
\hline N & & & \\
\hline
\end{tabular}

Note: "Sector Maximum" is the largest value of the 16 wind transport directions. Distances ranging from $100 \mathrm{~m}$ to $600 \mathrm{~m}$ in $50-\mathrm{m}$ increments were used to determine the worst-case location. The distance with the largest air transport factors is listed at the bottom of each column. 
Table C-5. Air Transport Factors for Releases from the Cold Vacuum Drying Facility's Heating, Ventilation, and Air Conditioning Stack (48 Feet) to the Nearest Point of Public Access.

\begin{tabular}{|c|c|c|c|c|c|}
\hline \multirow{2}{*}{$\begin{array}{c}\text { Transport } \\
\text { direction }\end{array}$} & \multirow{2}{*}{$\begin{array}{c}\text { Distance } \\
\text { (meters) }\end{array}$} & \multicolumn{5}{|c|}{ Air transport factors, s/m ${ }^{3}$} \\
\cline { 3 - 6 } & 12,650 & $4.12 \mathrm{E}-05$ & $2.06 \mathrm{E}-05$ & $1.61 \mathrm{E}-05$ & $6.58 \mathrm{E}-08$ \\
\hline S & 11,340 & $3.70 \mathrm{E}-05$ & $1.67 \mathrm{E}-05$ & $1.39 \mathrm{E}-05$ & $4.96 \mathrm{E}-08$ \\
\hline SSW & 1,690 & $2.22 \mathrm{E}-04$ & $1.93 \mathrm{E}-04$ & $8.55 \mathrm{E}-05$ & $8.14 \mathrm{E}-07$ \\
\hline SW & 700 & $6.19 \mathrm{E}-04$ & $3.94 \mathrm{E}-04$ & $1.62 \mathrm{E}-04$ & $3.31 \mathrm{E}-06$ \\
\hline WSW & 650 & $9.93 \mathrm{E}-04$ & $4.39 \mathrm{E}-04$ & $1.92 \mathrm{E}-04$ & $7.16 \mathrm{E}-06$ \\
\hline W & 580 & $7.74 \mathrm{E}-04$ & $4.30 \mathrm{E}-04$ & $2.01 \mathrm{E}-04$ & $5.69 \mathrm{E}-06$ \\
\hline WNW & 580 & $7.15 \mathrm{E}-04$ & $4.29 \mathrm{E}-04$ & $1.96 \mathrm{E}-04$ & $4.69 \mathrm{E}-06$ \\
\hline NW & 580 & $5.61 \mathrm{E}-04$ & $4.17 \mathrm{E}-04$ & $1.85 \mathrm{E}-04$ & $3.34 \mathrm{E}-06$ \\
\hline NNW & 580 & $6.85 \mathrm{E}-04$ & $4.28 \mathrm{E}-04$ & $1.94 \mathrm{E}-04$ & $4.21 \mathrm{E}-06$ \\
\hline N & 640 & $4.39 \mathrm{E}-04$ & $3.91 \mathrm{E}-04$ & $1.64 \mathrm{E}-04$ & $2.92 \mathrm{E}-06$ \\
\hline NNE & 860 & $4.66 \mathrm{E}-04$ & $2.97 \mathrm{E}-04$ & $1.41 \mathrm{E}-04$ & $2.79 \mathrm{E}-06$ \\
\hline NE & 2,540 & $2.15 \mathrm{E}-04$ & $1.73 \mathrm{E}-04$ & $8.40 \mathrm{E}-05$ & $9.09 \mathrm{E}-07$ \\
\hline ENE & 11,470 & $5.97 \mathrm{E}-05$ & $4.14 \mathrm{E}-05$ & $2.98 \mathrm{E}-05$ & $1.75 \mathrm{E}-07$ \\
\hline E & 12,060 & $5.07 \mathrm{E}-05$ & $3.12 \mathrm{E}-05$ & $2.32 \mathrm{E}-05$ & $9.93 \mathrm{E}-08$ \\
\hline ESE & 15,150 & $3.77 \mathrm{E}-05$ & $1.97 \mathrm{E}-05$ & $1.55 \mathrm{E}-05$ & $5.39 \mathrm{E}-08$ \\
\hline SE & 15,600 & $3.44 \mathrm{E}-05$ & $1.63 \mathrm{E}-05$ & $1.31 \mathrm{E}-05$ & $4.41 \mathrm{E}-08$ \\
\hline SSE & $9.93 \mathrm{E}-04$ & $4.39 \mathrm{E}-04$ & $2.01 \mathrm{E}-04$ & $7.16 \mathrm{E}-06$ \\
\hline Sector Maximumual & $(99.5 \%)$ & $5.22 \mathrm{E}-04$ & $4.18 \mathrm{E}-04$ & $1.83 \mathrm{E}-04$ & $2.27 \mathrm{E}-06$ \\
\hline
\end{tabular}


Table C-6. Air Transport Factors for Releases from the Cold Vacuum Drying Facility's Heating, Ventilation, and Air Conditioning Stack (48 Feet) to the Hanford Site Boundary.

\begin{tabular}{|c|c|c|c|c|c|}
\hline \multirow{2}{*}{$\begin{array}{c}\text { Transport } \\
\text { direction }\end{array}$} & \multirow{2}{*}{$\begin{array}{c}\text { Distance } \\
\text { (meters) }\end{array}$} & \multicolumn{5}{|c|}{ Air transport factors, s/m } \\
\cline { 3 - 6 } & Fumigation & $<0.5 \mathrm{hr}$ & 0.5 to $2 \mathrm{hr}$ & Annual \\
\hline S & 24,960 & $2.23 \mathrm{E}-05$ & $9.09 \mathrm{E}-06$ & $7.77 \mathrm{E}-06$ & $2.60 \mathrm{E}-08$ \\
\hline SSW & 17,130 & $2.55 \mathrm{E}-05$ & $1.03 \mathrm{E}-05$ & $8.95 \mathrm{E}-06$ & $2.80 \mathrm{E}-08$ \\
\hline SW & 15,510 & $3.01 \mathrm{E}-05$ & $1.30 \mathrm{E}-05$ & $1.09 \mathrm{E}-05$ & $3.46 \mathrm{E}-08$ \\
\hline WSW & 11,990 & $4.01 \mathrm{E}-05$ & $1.91 \mathrm{E}-05$ & $1.51 \mathrm{E}-05$ & $6.11 \mathrm{E}-08$ \\
\hline W & 10,090 & $6.02 \mathrm{E}-05$ & $3.95 \mathrm{E}-05$ & $2.82 \mathrm{E}-05$ & $1.48 \mathrm{E}-07$ \\
\hline WNW & 8,740 & $5.33 \mathrm{E}-05$ & $2.78 \mathrm{E}-05$ & $2.08 \mathrm{E}-05$ & $1.14 \mathrm{E}-07$ \\
\hline NW & 8,740 & $5.02 \mathrm{E}-05$ & $2.52 \mathrm{E}-05$ & $1.95 \mathrm{E}-05$ & $9.25 \mathrm{E}-08$ \\
\hline NNW & 8,740 & $4.21 \mathrm{E}-05$ & $1.76 \mathrm{E}-05$ & $1.16 \mathrm{E}-05$ & $6.47 \mathrm{E}-08$ \\
\hline N & 8,930 & $4.77 \mathrm{E}-05$ & $2.23 \mathrm{E}-05$ & $1.79 \mathrm{E}-05$ & $7.96 \mathrm{E}-08$ \\
\hline NNE & 10,750 & $3.68 \mathrm{E}-05$ & $9.74 \mathrm{E}-06$ & $9.63 \mathrm{E}-06$ & $4.99 \mathrm{E}-08$ \\
\hline NE & 15,390 & $3.13 \mathrm{E}-05$ & $1.36 \mathrm{E}-05$ & $1.13 \mathrm{E}-05$ & $4.44 \mathrm{E}-08$ \\
\hline ENE & 20,080 & $3.04 \mathrm{E}-05$ & $1.54 \mathrm{E}-05$ & $1.26 \mathrm{E}-05$ & $4.96 \mathrm{E}-08$ \\
\hline E & 20,510 & $3.53 \mathrm{E}-05$ & $2.09 \mathrm{E}-05$ & $1.68 \mathrm{E}-05$ & $7.91 \mathrm{E}-08$ \\
\hline ESE & 20,670 & $3.11 \mathrm{E}-05$ & $1.65 \mathrm{E}-05$ & $1.34 \mathrm{E}-05$ & $4.76 \mathrm{E}-08$ \\
\hline SE & 21,790 & $2.72 \mathrm{E}-05$ & $1.28 \mathrm{E}-05$ & $1.06 \mathrm{E}-05$ & $3.29 \mathrm{E}-08$ \\
\hline SSE & 24,960 & $2.25 \mathrm{E}-05$ & $9.25 \mathrm{E}-06$ & $7.90 \mathrm{E}-06$ & $2.33 \mathrm{E}-08$ \\
\hline Sector Maximum $(99.5 \%)$ & $6.02 \mathrm{E}-05$ & $3.95 \mathrm{E}-05$ & $2.82 \mathrm{E}-05$ & $1.48 \mathrm{E}-07$ \\
\hline \multicolumn{2}{|c|}{ Overall Site $(95 \%)$} & $4.03 \mathrm{E}-05$ & $2.43 \mathrm{E}-05$ & $1.88 \mathrm{E}-05$ & $6.10 \mathrm{E}-08$ \\
\hline
\end{tabular}


Table C-7. Air Transport Factors for Releases from the Canister Storage Building's Heating, Ventilation, and Air Conditioning Stack (75 Feet) to the Onsite Worker.

\begin{tabular}{|c|c|c|c|c|}
\hline \multirow{2}{*}{$\begin{array}{c}\text { Transport } \\
\text { direction }\end{array}$} & \multicolumn{4}{|c|}{ Air transport factors, s/m ${ }^{3}$} \\
\cline { 2 - 5 } & Fumigation & $<0.5 \mathrm{hr}$ & 0.5 to $2 \mathrm{hr}$ & Annual \\
\hline S & $3.45 \mathrm{E}-03$ & $5.60 \mathrm{E}-04$ & $2.61 \mathrm{E}-04$ & $6.08 \mathrm{E}-06$ \\
\hline SSW & $2.53 \mathrm{E}-03$ & $2.58 \mathrm{E}-04$ & $1.16 \mathrm{E}-04$ & $4.05 \mathrm{E}-06$ \\
\hline SW & $2.60 \mathrm{E}-03$ & $2.35 \mathrm{E}-04$ & $1.06 \mathrm{E}-04$ & $3.27 \mathrm{E}-06$ \\
\hline WSW & $2.59 \mathrm{E}-03$ & $3.32 \mathrm{E}-04$ & $1.53 \mathrm{E}-04$ & $3.54 \mathrm{E}-06$ \\
\hline W & $4.06 \mathrm{E}-03$ & $5.74 \mathrm{E}-04$ & $2.66 \mathrm{E}-04$ & $5.66 \mathrm{E}-06$ \\
\hline WNW & $3.49 \mathrm{E}-03$ & $2.46 \mathrm{E}-04$ & $1.11 \mathrm{E}-04$ & $3.91 \mathrm{E}-06$ \\
\hline NW & $3.68 \mathrm{E}-03$ & $2.28 \mathrm{E}-04$ & $1.03 \mathrm{E}-04$ & $3.18 \mathrm{E}-06$ \\
\hline NNW & $3.61 \mathrm{E}-03$ & $1.94 \mathrm{E}-04$ & $8.98 \mathrm{E}-05$ & $2.05 \mathrm{E}-06$ \\
\hline N & $4.24 \mathrm{E}-03$ & $1.87 \mathrm{E}-04$ & $8.72 \mathrm{E}-05$ & $1.99 \mathrm{E}-06$ \\
\hline NNE & $2.95 \mathrm{E}-03$ & $7.57 \mathrm{E}-05$ & $4.61 \mathrm{E}-05$ & $1.07 \mathrm{E}-06$ \\
\hline NE & $3.09 \mathrm{E}-03$ & $1.06 \mathrm{E}-04$ & $4.93 \mathrm{E}-05$ & $1.38 \mathrm{E}-06$ \\
\hline ENE & $3.34 \mathrm{E}-03$ & $1.32 \mathrm{E}-04$ & $5.96 \mathrm{E}-05$ & $2.12 \mathrm{E}-06$ \\
\hline E & $4.85 \mathrm{E}-03$ & $1.86 \mathrm{E}-04$ & $8.70 \mathrm{E}-05$ & $2.64 \mathrm{E}-06$ \\
\hline ESE & $4.24 \mathrm{E}-03$ & $1.97 \mathrm{E}-04$ & $9.12 \mathrm{E}-05$ & $2.94 \mathrm{E}-06$ \\
\hline SE & $4.12 \mathrm{E}-03$ & $2.31 \mathrm{E}-04$ & $1.05 \mathrm{E}-04$ & $4.08 \mathrm{E}-06$ \\
\hline SSE & $3.40 \mathrm{E}-03$ & $2.46 \mathrm{E}-04$ & $1.11 \mathrm{E}-04$ & $3.99 \mathrm{E}-06$ \\
\hline Sector Maximum & $4.85 \mathrm{E}-03$ & $5.74 \mathrm{E}-04$ & $2.66 \mathrm{E}-04$ & $6.08 \mathrm{E}-06$ \\
$(99.5 \%)$ & $100 \mathrm{~m} \mathrm{E}$ & $100 \mathrm{~m} \mathrm{~W}$ & $150 \mathrm{~m} \mathrm{~W}$ & $100 \mathrm{~m} \mathrm{~S}$ \\
\hline Overall Site $(95 \%)$ & $4.63 \mathrm{E}-03$ & $5.60 \mathrm{E}-04$ & $2.12 \mathrm{E}-04$ & $3.25 \mathrm{E}-06$ \\
\hline No & $100 \mathrm{~m}$ & $250 \mathrm{~m}$ & $150 \mathrm{~m}$ & $100 \mathrm{~m}$ \\
\hline
\end{tabular}

Note: Distances ranging from $100 \mathrm{~m}$ to $600 \mathrm{~m}$ in $50-\mathrm{m}$ increments were used to determine the worst-case location. The air transport factors are shown for the largest distance, which is listed at the bottom of each column. 
Table C-8. Air Transport Factors for Releases from the Canister Storage Building's Heating, Ventilation, and Air Conditioning Stack (75 Feet) to the Nearest Point of Public Access.

\begin{tabular}{|c|c|c|c|c|c|}
\hline \multirow{2}{*}{$\begin{array}{c}\text { Transport } \\
\text { direction }\end{array}$} & \multirow{2}{*}{$\begin{array}{c}\text { Distance } \\
\text { (meters) }\end{array}$} & \multicolumn{5}{|c|}{ Air transport factors, s/m } \\
\cline { 3 - 6 } & Fumigation & $<0.5 \mathrm{hr}$ & 0.5 to $2 \mathrm{hr}$ & Annual \\
\hline S & 7,830 & $4.51 \mathrm{E}-05$ & $1.78 \mathrm{E}-05$ & $1.08 \mathrm{E}-05$ & $7.07 \mathrm{E}-08$ \\
\hline SSW & 7,830 & $3.16 \mathrm{E}-05$ & $9.05 \mathrm{E}-06$ & $6.93 \mathrm{E}-06$ & $4.36 \mathrm{E}-08$ \\
\hline SW & 7,830 & $3.17 \mathrm{E}-05$ & $1.18 \mathrm{E}-05$ & $7.43 \mathrm{E}-06$ & $4.18 \mathrm{E}-08$ \\
\hline WSW & 7,830 & $3.17 \mathrm{E}-05$ & $1.18 \mathrm{E}-05$ & $7.46 \mathrm{E}-06$ & $4.14 \mathrm{E}-08$ \\
\hline W & 9,280 & $4.47 \mathrm{E}-05$ & $2.02 \mathrm{E}-05$ & $1.17 \mathrm{E}-05$ & $5.72 \mathrm{E}-08$ \\
\hline WNW & 10,510 & $3.49 \mathrm{E}-05$ & $1.01 \mathrm{E}-05$ & $8.93 \mathrm{E}-06$ & $3.89 \mathrm{E}-08$ \\
\hline NW & 11,250 & $3.44 \mathrm{E}-05$ & $1.68 \mathrm{E}-05$ & $9.89 \mathrm{E}-06$ & $4.06 \mathrm{E}-08$ \\
\hline NNW & 11,250 & $3.39 \mathrm{E}-05$ & $1.69 \mathrm{E}-05$ & $9.93 \mathrm{E}-06$ & $4.04 \mathrm{E}-08$ \\
\hline N & 11,250 & $3.91 \mathrm{E}-05$ & $1.87 \mathrm{E}-05$ & $1.07 \mathrm{E}-05$ & $4.24 \mathrm{E}-08$ \\
\hline NNE & 12,750 & $2.41 \mathrm{E}-05$ & $7.71 \mathrm{E}-06$ & $5.39 \mathrm{E}-06$ & $2.02 \mathrm{E}-08$ \\
\hline NE & 12,670 & $2.58 \mathrm{E}-05$ & $7.91 \mathrm{E}-06$ & $6.18 \mathrm{E}-06$ & $2.42 \mathrm{E}-08$ \\
\hline ENE & 12,670 & $2.84 \mathrm{E}-05$ & $1.27 \mathrm{E}-05$ & $8.11 \mathrm{E}-06$ & $3.21 \mathrm{E}-08$ \\
\hline E & 12,670 & $3.97 \mathrm{E}-05$ & $1.83 \mathrm{E}-05$ & $1.03 \mathrm{E}-05$ & $8.60 \mathrm{E}-08$ \\
\hline ESE & 14,230 & $3.16 \mathrm{E}-05$ & $1.49 \mathrm{E}-05$ & $8.71 \mathrm{E}-06$ & $7.85 \mathrm{E}-08$ \\
\hline SE & 11,070 & $3.87 \mathrm{E}-05$ & $1.87 \mathrm{E}-05$ & $1.07 \mathrm{E}-05$ & $6.77 \mathrm{E}-08$ \\
\hline SSE & 8,490 & $4.13 \mathrm{E}-05$ & $1.71 \mathrm{E}-05$ & $1.03 \mathrm{E}-05$ & $5.58 \mathrm{E}-08$ \\
\hline Sector Maximum $(99.5 \%)$ & $4.51 \mathrm{E}-05$ & $2.02 \mathrm{E}-05$ & $1.17 \mathrm{E}-05$ & $8.60 \mathrm{E}-08$ \\
\hline \multicolumn{2}{|r|}{ Overall Site $(95 \%)$} & $4.36 \mathrm{E}-05$ & $1.95 \mathrm{E}-05$ & $1.05 \mathrm{E}-05$ & $4.88 \mathrm{E}-08$ \\
\hline
\end{tabular}


Table C-9. Air Transport Factors for Releases from the Canister Storage Building's Heating,

Ventilation, and Air Conditioning Stack ( 75 Feet) to the Hanford Site Boundary.

\begin{tabular}{|c|c|c|c|c|c|}
\hline \multirow{2}{*}{$\begin{array}{l}\text { Transport } \\
\text { direction }\end{array}$} & \multirow{2}{*}{$\begin{array}{l}\text { Distance } \\
\text { (meters) }\end{array}$} & \multicolumn{4}{|c|}{ Air transport factors, $\mathrm{s} / \mathrm{m}^{3}$} \\
\hline & & Fumigation & $<0.5 \mathrm{hr}$ & 0.5 to $2 \mathrm{hr}$ & Annual \\
\hline $\mathrm{S}$ & 16,260 & $2.33 \mathrm{E}-05$ & $5.75 \mathrm{E}-06$ & $3.96 \mathrm{E}-06$ & $2.52 \mathrm{E}-08$ \\
\hline SSW & 16,260 & $1.63 \mathrm{E}-05$ & $3.69 \mathrm{E}-06$ & $2.97 \mathrm{E}-06$ & $1.54 \mathrm{E}-08$ \\
\hline SW & 16,260 & $1.64 \mathrm{E}-05$ & $4.75 \mathrm{E}-06$ & $3.20 \mathrm{E}-06$ & $1.49 \mathrm{E}-08$ \\
\hline WSW & 17,910 & $1.50 \mathrm{E}-05$ & $4.23 \mathrm{E}-06$ & $2.87 \mathrm{E}-06$ & $1.30 \mathrm{E}-08$ \\
\hline W & 18,400 & $2.41 \mathrm{E}-05$ & $9.07 \mathrm{E}-06$ & $5.68 \mathrm{E}-06$ & 2.22E-08 \\
\hline WNW & 18,400 & $2.11 \mathrm{E}-05$ & $5.15 \mathrm{E}-06$ & $3.44 \mathrm{E}-06$ & $1.81 \mathrm{E}-08$ \\
\hline NW & 18,870 & $2.16 \mathrm{E}-05$ & $9.14 \mathrm{E}-06$ & $5.70 \mathrm{E}-06$ & $2.01 \mathrm{E}-08$ \\
\hline NNW & 19,450 & $2.07 \mathrm{E}-05$ & 8.87E-06 & $5.54 \mathrm{E}-06$ & $1.93 \mathrm{E}-08$ \\
\hline$N$ & 19,450 & $2.38 \mathrm{E}-05$ & $9.73 \mathrm{E}-06$ & $5.99 \mathrm{E}-06$ & $2.04 \mathrm{E}-08$ \\
\hline NNE & 20,390 & $1.58 \mathrm{E}-05$ & $4.21 \mathrm{E}-06$ & $3.02 \mathrm{E}-06$ & $1.07 \mathrm{E}-08$ \\
\hline NE & 17,540 & $1.92 \mathrm{E}-05$ & $5.29 \mathrm{E}-06$ & $3.63 \mathrm{E}-06$ & $1.56 \mathrm{E}-08$ \\
\hline ENE & 17,390 & $2.13 \mathrm{E}-05$ & $8.75 \mathrm{E}-06$ & $5.49 \mathrm{E}-06$ & $2.09 \mathrm{E}-08$ \\
\hline$E$ & 17,390 & $2.99 \mathrm{E}-05$ & $1.25 \mathrm{E}-05$ & $7.42 \mathrm{E}-06$ & $5.63 \mathrm{E}-08$ \\
\hline ESE & 17,390 & $2.64 \mathrm{E}-05$ & 1.17E-05 & $7.05 \mathrm{E}-06$ & $5.99 \mathrm{E}-08$ \\
\hline $\mathrm{SE}$ & 20,630 & $2.20 \mathrm{E}-05$ & $8.90 \mathrm{E}-06$ & $5.53 \mathrm{E}-06$ & $2.89 \mathrm{E}-08$ \\
\hline SSE & 18,830 & $2.01 \mathrm{E}-05$ & $4.87 \mathrm{E}-06$ & $3.34 \mathrm{E}-06$ & $1.85 \mathrm{E}-08$ \\
\hline \multicolumn{2}{|c|}{ Sector Maximum $(99.5 \%)$} & $2.99 \mathrm{E}-05$ & $1.25 \mathrm{E}-05$ & $7.42 \mathrm{E}-06$ & $5.99 \mathrm{E}-08$ \\
\hline \multicolumn{2}{|c|}{ Overall Site $(95 \%)$} & $2.80 \mathrm{E}-05$ & $1.12 \mathrm{E}-05$ & $6.74 \mathrm{E}-06$ & 2.37E-08 \\
\hline
\end{tabular}


Table C-10. Air Transport Factors for Releases from the Canister Storage Building Natural Circulation Stack (156 Feet) to the Onsite Worker.

\begin{tabular}{|c|c|c|c|c|}
\hline \multirow{2}{*}{$\begin{array}{l}\text { Transport } \\
\text { direction }\end{array}$} & \multicolumn{4}{|c|}{ Air transport factors, $\mathrm{s} / \mathrm{m}^{3}$} \\
\hline & Fumigation & $<0.5 \mathrm{hr}$ & 0.5 to $2 \mathrm{hr}$ & Annual \\
\hline$S$ & $2.20 \mathrm{E}-03$ & $1.77 \mathrm{E}-04$ & $4.20 \mathrm{E}-05$ & $789 \mathrm{E}-07$ \\
\hline SSW & $1.53 \mathrm{E}-03$ & $8.90 \mathrm{E}-05$ & $2.40 \mathrm{E}-05$ & 5.22E-07 \\
\hline SW & $1.54 \mathrm{E}-03$ & $8.54 \mathrm{E}-05$ & $2.29 \mathrm{E}-05$ & 4.09E-07 \\
\hline WSW & $1.54 \mathrm{E}-03$ & $1.04 \mathrm{E}-04$ & $2.37 \mathrm{E}-05$ & $4.33 \mathrm{E}-07$ \\
\hline W & $2.56 \mathrm{E}-03$ & $1.93 \mathrm{E}-04$ & $4.84 \mathrm{E}-05$ & $7.12 \mathrm{E}-07$ \\
\hline WN.W & $2.23 \mathrm{E}-03$ & $8.66 \mathrm{E}-05$ & $2.40 \mathrm{E}-05$ & $5.05 \mathrm{E}-07$ \\
\hline NW & $2.34 \mathrm{E}-03$ & $8.46 \mathrm{E}-05$ & $2.32 \mathrm{E}-05$ & 4.18E-07 \\
\hline NNW & $2.30 \mathrm{E}-03$ & $6.36 \mathrm{E}-05$ & $2.01 \mathrm{E}-05$ & $2.78 \mathrm{E}-07$ \\
\hline $\mathrm{N}$ & $2.67 \mathrm{E}-03$ & $5.50 \mathrm{E}-05$ & $1.84 \mathrm{E}-05$ & $2.63 \mathrm{E}-07$ \\
\hline NNE & $1.82 \mathrm{E}-03$ & $1.38 \mathrm{E}-05$ & $3.47 \mathrm{E}-06$ & $1.44 \mathrm{E}-07$ \\
\hline $\mathrm{NE}$ & $1.94 \mathrm{E}-03$ & $3.69 \mathrm{E}-05$ & $1.12 \mathrm{E}-05$ & $1.98 \mathrm{E}-07$ \\
\hline ENE & 2.14E-03 & 4.79E-05 & $1.31 \mathrm{E}-05$ & $3.12 \mathrm{E}-07$ \\
\hline $\mathrm{E}$ & $3.04 \mathrm{E}-03$ & $5.84 \mathrm{E}-05$ & $1.84 \mathrm{E}-05$ & $3.73 \mathrm{E}-07$ \\
\hline ESE & $2.67 \mathrm{E}-03$ & $7.16 \mathrm{E}-05$ & $2.06 \mathrm{E}-05$ & $4.12 \mathrm{E}-07$ \\
\hline $\mathrm{SE}$ & $2.60 \mathrm{E}-03$ & $8.50 \mathrm{E}-05$ & $2.31 \mathrm{E}-05$ & 5.64E-07 \\
\hline SSE & $2.17 \mathrm{E}-03$ & 8.67E-05 & $2.41 \mathrm{E}-05$ & $5.17 \mathrm{E}-07$ \\
\hline $\begin{array}{l}\text { Sector Maximum } \\
\quad(99.5 \%)\end{array}$ & $\begin{array}{l}3.04 \mathrm{E}-03 \\
100 \mathrm{~m} \mathrm{E}\end{array}$ & $\begin{array}{l}1.93 \mathrm{E}-04 \\
150 \mathrm{~m} \cdot \mathrm{W}\end{array}$ & $\begin{array}{l}484 \mathrm{E}-05 \\
300 \mathrm{~m} \mathrm{~W}\end{array}$ & $\begin{array}{l}7.89 \mathrm{E}-07 \\
250 \mathrm{~m} \mathrm{~S}\end{array}$ \\
\hline Overall Site $(95 \%)$ & $\begin{array}{c}2.90 \mathrm{E}-03 \\
100 \mathrm{~m}\end{array}$ & $\begin{array}{c}1.83 \mathrm{E}-04 \\
400 \mathrm{~m}\end{array}$ & $\begin{array}{l}3.36 \mathrm{E}-05 \\
250 \mathrm{~m}\end{array}$ & $\begin{array}{c}4.28 \mathrm{E}-07 \\
250 \mathrm{~m}\end{array}$ \\
\hline
\end{tabular}

Note: Distances ranging from $100 \mathrm{~m}$ to $600 \mathrm{~m}$ in 50 -m increments were used to determine the worstcase location. The air transport factors are shown for the largest distance, which is listed at the bottom of each column. 
Table C-11. Air Transport Factors for Releases from the Canister Storage Building Natural Circulation Stack (156 Feet) to the Nearest Point of Public Access.

\begin{tabular}{|c|c|c|c|c|c|}
\hline \multirow{2}{*}{$\begin{array}{c}\text { Transport } \\
\text { direction }\end{array}$} & \multirow{2}{*}{$\begin{array}{c}\text { Distance } \\
\text { (meters) }\end{array}$} & \multicolumn{5}{|c|}{ Air transport factors, s/m ${ }^{3}$} \\
\cline { 3 - 6 } & 7,830 & $2.81 \mathrm{E}-05$ & $1.07 \mathrm{E}-05$ & $6.66 \mathrm{E}-06$ & $430 \mathrm{E}-08$ \\
\hline SSW & 7,830 & $2.38 \mathrm{E}-05$ & $6.25 \mathrm{E}-06$ & $5.72 \mathrm{E}-06$ & $2.76 \mathrm{E}-08$ \\
\hline SW & 7,830 & $2.47 \mathrm{E}-05$ & $6.93 \mathrm{E}-06$ & $5.90 \mathrm{E}-06$ & $2.51 \mathrm{E}-08$ \\
\hline WSW & 7,830 & $2.47 \mathrm{E}-05$ & $6.99 \mathrm{E}-06$ & $5.85 \mathrm{E}-06$ & $2.44 \mathrm{E}-08$ \\
\hline W & 9,280 & $2.79 \mathrm{E}-05$ & $9.55 \mathrm{E}-06$ & $5.93 \mathrm{E}-06$ & $3.28 \mathrm{E}-08$ \\
\hline WNW & 10,510 & $2.18 \mathrm{E}-05$ & $7.92 \mathrm{E}-06$ & $5.01 \mathrm{E}-06$ & $2.16 \mathrm{E}-08$ \\
\hline NW & 11,250 & $2.15 \mathrm{E}-05$ & $8.12 \mathrm{E}-06$ & $4.79 \mathrm{E}-06$ & $2.18 \mathrm{E}-08$ \\
\hline NNW & 11,250 & $2.12 \mathrm{E}-05$ & $8.21 \mathrm{E}-06$ & $4.73 \mathrm{E}-06$ & $2.05 \mathrm{E}-08$ \\
\hline N & 11,250 & $2.44 \mathrm{E}-05$ & $9.85 \mathrm{E}-06$ & $5.23 \mathrm{E}-06$ & $2.05 \mathrm{E}-08$ \\
\hline NNE & 12,750 & $1.61 \mathrm{E}-05$ & $5.55 \mathrm{E}-06$ & $3.13 \mathrm{E}-06$ & $1.03 \mathrm{E}-08$ \\
\hline NE & 12,670 & $1.67 \mathrm{E}-05$ & $5.93 \mathrm{E}-06$ & $3.44 \mathrm{E}-06$ & $1.27 \mathrm{E}-08$ \\
\hline ENE & 12,670 & $1.77 \mathrm{E}-05$ & $6.79 \mathrm{E}-06$ & $3.92 \mathrm{E}-06$ & $1.68 \mathrm{E}-08$ \\
\hline E & 12,670 & $2.48 \mathrm{E}-05$ & $1.05 \mathrm{E}-05$ & $5.12 \mathrm{E}-06$ & $4.29 \mathrm{E}-08$ \\
\hline ESE & 14,230 & $1.98 \mathrm{E}-05$ & $8.27 \mathrm{E}-06$ & $4.10 \mathrm{E}-06$ & $4.24 \mathrm{E}-08$ \\
\hline SE & 11,070 & $2.42 \mathrm{E}-05$ & $9.66 \mathrm{E}-06$ & $5.41 \mathrm{E}-06$ & $3.78 \mathrm{E}-08$ \\
\hline SSE & 8,490 & $2.58 \mathrm{E}-05$ & $9.80 \mathrm{E}-06$ & $6.23 \mathrm{E}-06$ & $3.20 \mathrm{E}-08$ \\
\hline Sector Maximum $(99.5 \%)$ & $2.81 \mathrm{E}-05$ & $1.07 \mathrm{E}-05$ & $6.66 \mathrm{E}-06$ & $4.30 \mathrm{E}-08$ \\
\hline \multicolumn{2}{|c|}{ Overall Site $(95 \%)$} & $2.72 \mathrm{E}-05$ & $1.08 \mathrm{E}-05$ & $5.83 \mathrm{E}-06$ & $2.70 \mathrm{E}-08$ \\
\hline
\end{tabular}


Table C-12. Air Transport Factors for Releases from the Canister Storage Building Natural Circulation Stack (156 Feet) to the Hanford Site Boundary.

\begin{tabular}{|c|c|c|c|c|c|}
\hline \multirow{2}{*}{$\begin{array}{c}\text { Transport } \\
\text { direction }\end{array}$} & \multirow{2}{*}{$\begin{array}{c}\text { Distance } \\
\text { (meters) }\end{array}$} & \multicolumn{5}{|c|}{ Air transport factors, s/m ${ }^{3}$} \\
\cline { 3 - 6 } & Fumigation & $<0.5 \mathrm{hr}$ & 0.5 to $2 \mathrm{hr}$ & Annual \\
\hline S & 16,260 & $1.46 \mathrm{E}-05$ & $4.44 \mathrm{E}-06$ & $2.98 \mathrm{E}-06$ & $1.64 \mathrm{E}-08$ \\
\hline SSW & 16,260 & $1.12 \mathrm{E}-05$ & $2.62 \mathrm{E}-06$ & $2.01 \mathrm{E}-06$ & $1.04 \mathrm{E}-08$ \\
\hline SW & 16,260 & $1.14 \mathrm{E}-05$ & $2.88 \mathrm{E}-06$ & $2.09 \mathrm{E}-06$ & $9.55 \mathrm{E}-09$ \\
\hline WSW & 17,910 & $1.03 \mathrm{E}-05$ & $2.58 \mathrm{E}-06$ & $1.94 \mathrm{E}-06$ & $8.24 \mathrm{E}-09$ \\
\hline W & 18,400 & $1.51 \mathrm{E}-05$ & $4.67 \mathrm{E}-06$ & $2.99 \mathrm{E}-06$ & $1.36 \mathrm{E}-08$ \\
\hline WNW & 18,400 & $1.32 \mathrm{E}-05$ & $4.20 \mathrm{E}-06$ & $2.60 \mathrm{E}-06$ & $1.06 \mathrm{E}-08$ \\
\hline NW & 18,870 & $1.35 \mathrm{E}-05$ & $4.70 \mathrm{E}-06$ & $2.66 \mathrm{E}-06$ & $1.14 \mathrm{E}-08$ \\
\hline NNW & 19,450 & $1.29 \mathrm{E}-05$ & $4.59 \mathrm{E}-06$ & $2.52 \mathrm{E}-06$ & $1.05 \mathrm{E}-08$ \\
\hline N & 19,450 & $1.49 \mathrm{E}-05$ & $5.34 \mathrm{E}-06$ & $2.94 \mathrm{E}-06$ & $1.06 \mathrm{E}-08$ \\
\hline NNE & 20,390 & $1.02 \mathrm{E}-05$ & $3.04 \mathrm{E}-06$ & $1.98 \mathrm{E}-06$ & $5.78 \mathrm{E}-09$ \\
\hline NE & 17,540 & $1.23 \mathrm{E}-05$ & $3.99 \mathrm{E}-06$ & $2.43 \mathrm{E}-06$ & $8.49 \mathrm{E}-09$ \\
\hline ENE & 17,390 & $1.33 \mathrm{E}-05$ & $4.82 \mathrm{E}-06$ & $2.68 \mathrm{E}-06$ & $1.14 \mathrm{E}-08$ \\
\hline E & 17,390 & $1.87 \mathrm{E}-05$ & $7.23 \mathrm{E}-06$ & $3.75 \mathrm{E}-06$ & $2.93 \mathrm{E}-08$ \\
\hline ESE & 17,390 & $1.65 \mathrm{E}-05$ & $6.57 \mathrm{E}-06$ & $3.31 \mathrm{E}-06$ & $\cdots 3.31 \mathrm{E}-08$ \\
\hline SE & 20,630 & $1.38 \mathrm{E}-05$ & $4.85 \mathrm{E}-06$ & $2.68 \mathrm{E}-06$ & $1.71 \mathrm{E}-08$ \\
\hline SSE & 18,830 & $1.26 \mathrm{E}-05$ & $3.85 \mathrm{E}-06$ & $2.47 \mathrm{E}-06$ & $1.14 \mathrm{E}-08$ \\
\hline Sector Maximum $(99.5 \%)$ & $1.87 \mathrm{E}-05$ & $7.23 \mathrm{E}-06$ & $3.75 \mathrm{E}-06$ & $3.31 \mathrm{E}-08$ \\
\hline \multicolumn{2}{|c|}{ Overall Site $(95 \%)$} & $1.75 \mathrm{E}-05$ & $6.56 \mathrm{E}-06$ & $3.49 \mathrm{E}-06$ & $1.36 \mathrm{E}-08$ \\
\hline
\end{tabular}


APPENDIX D

GXQ INPUT FILES FOR ELEVATED RELEASES 
HNF-SD-SNF-TI-059 REV 2

This page intentionally left blank. 


\section{Cold Vacuum Drying Facility, Heating, Ventilating, and Air Conditioning Stack - Plume Rise Only}

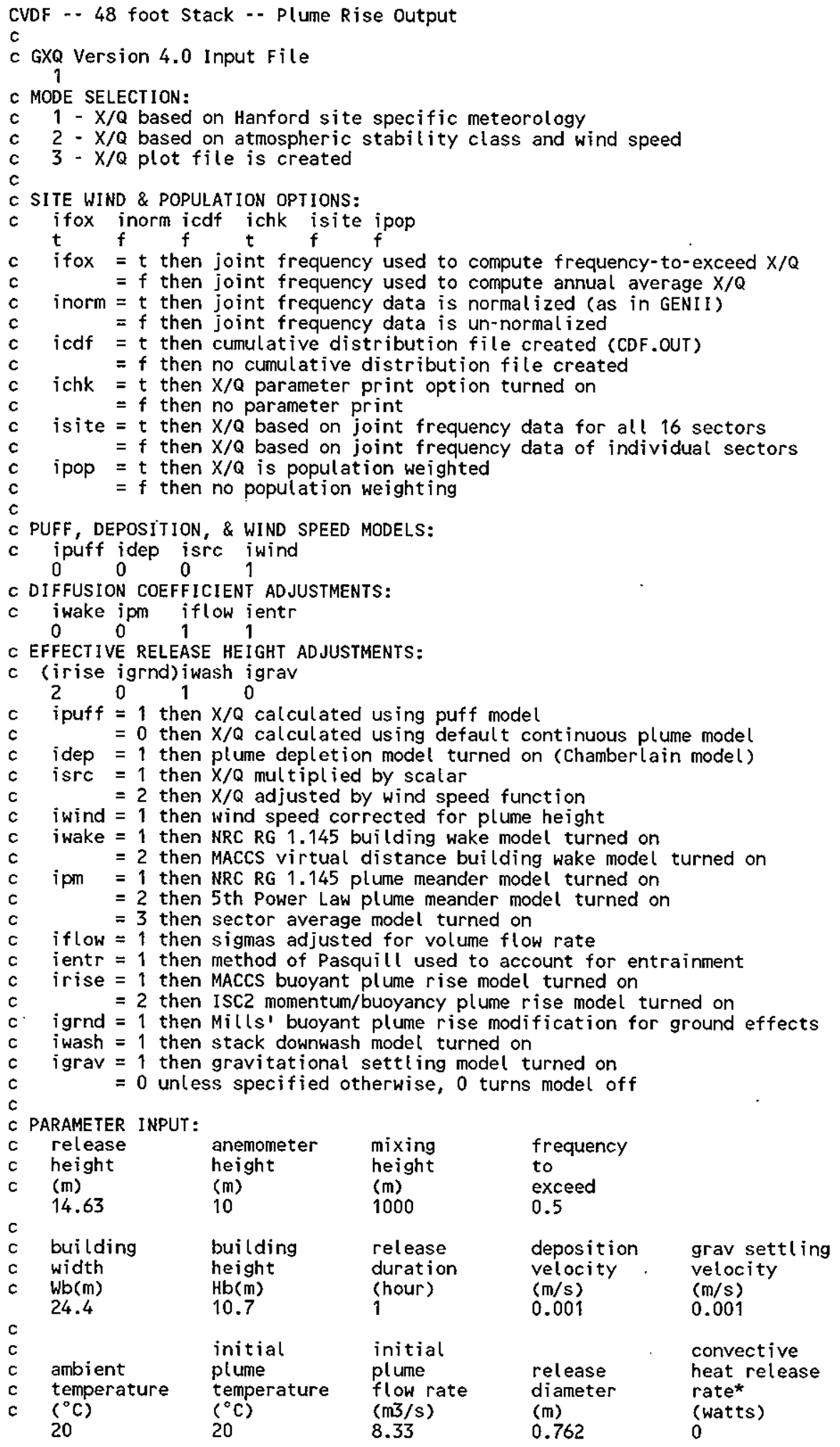




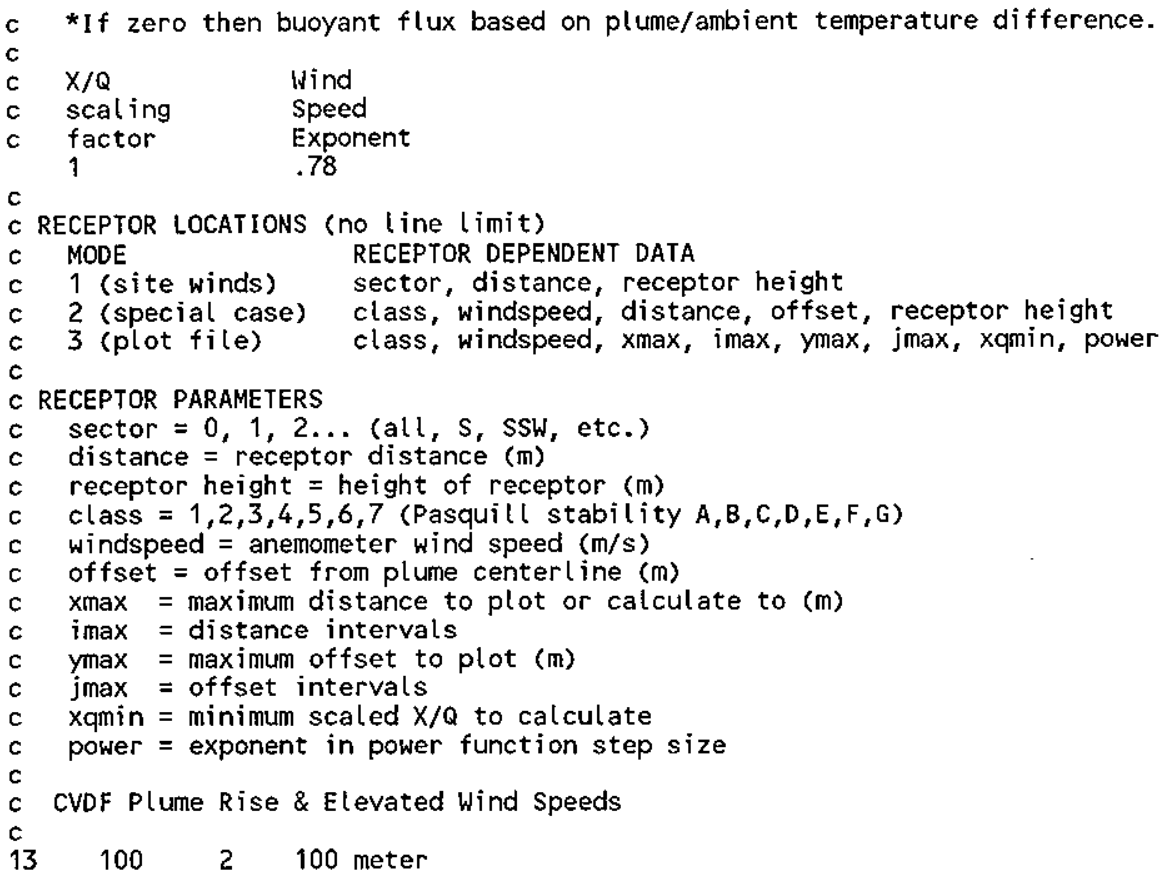

\section{Cold Vacuum Drying Facility, Heating, Ventilating, and Air Conditioning Stack - Fumigation - Sector Maximum 99.5\%}

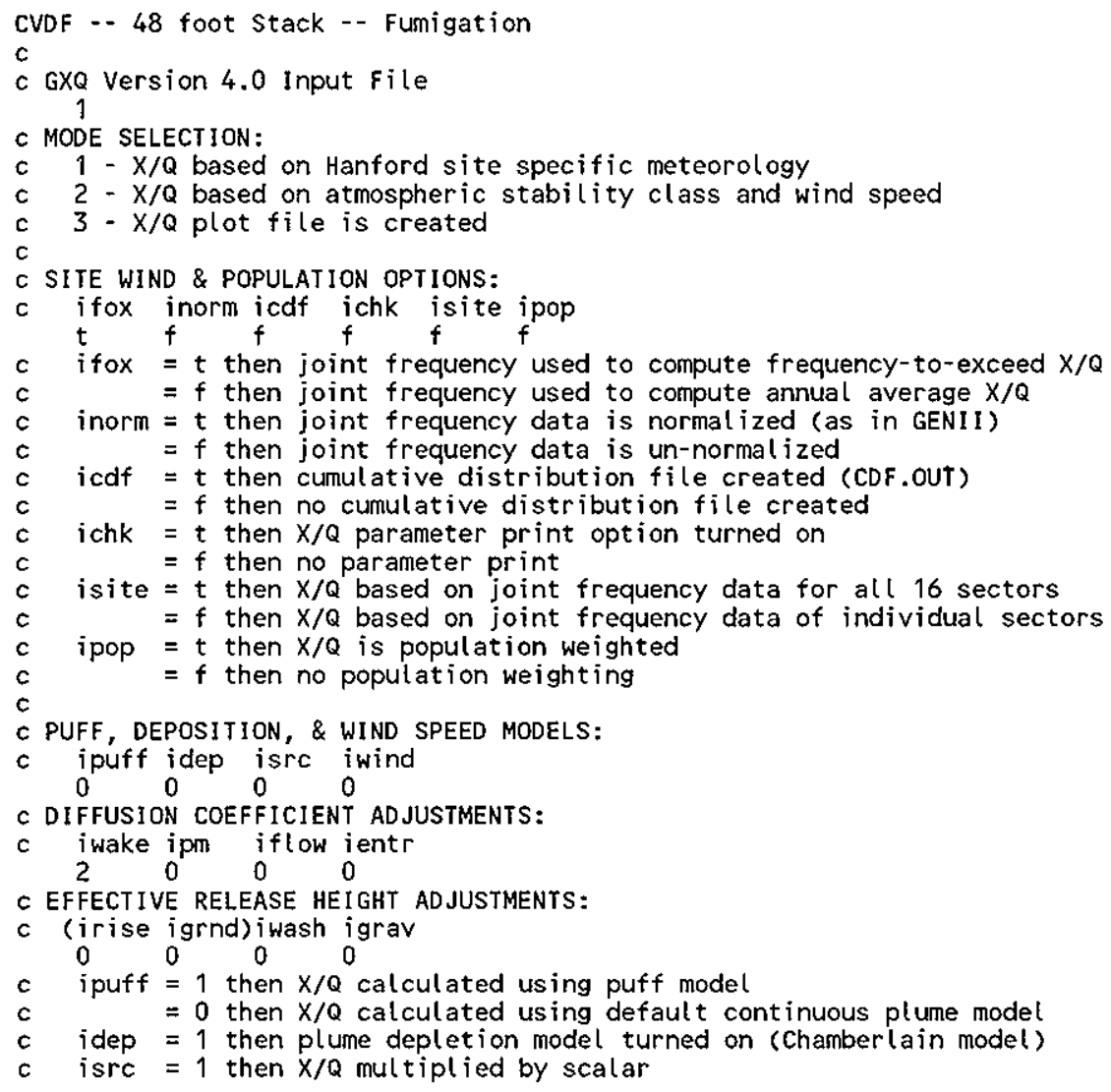




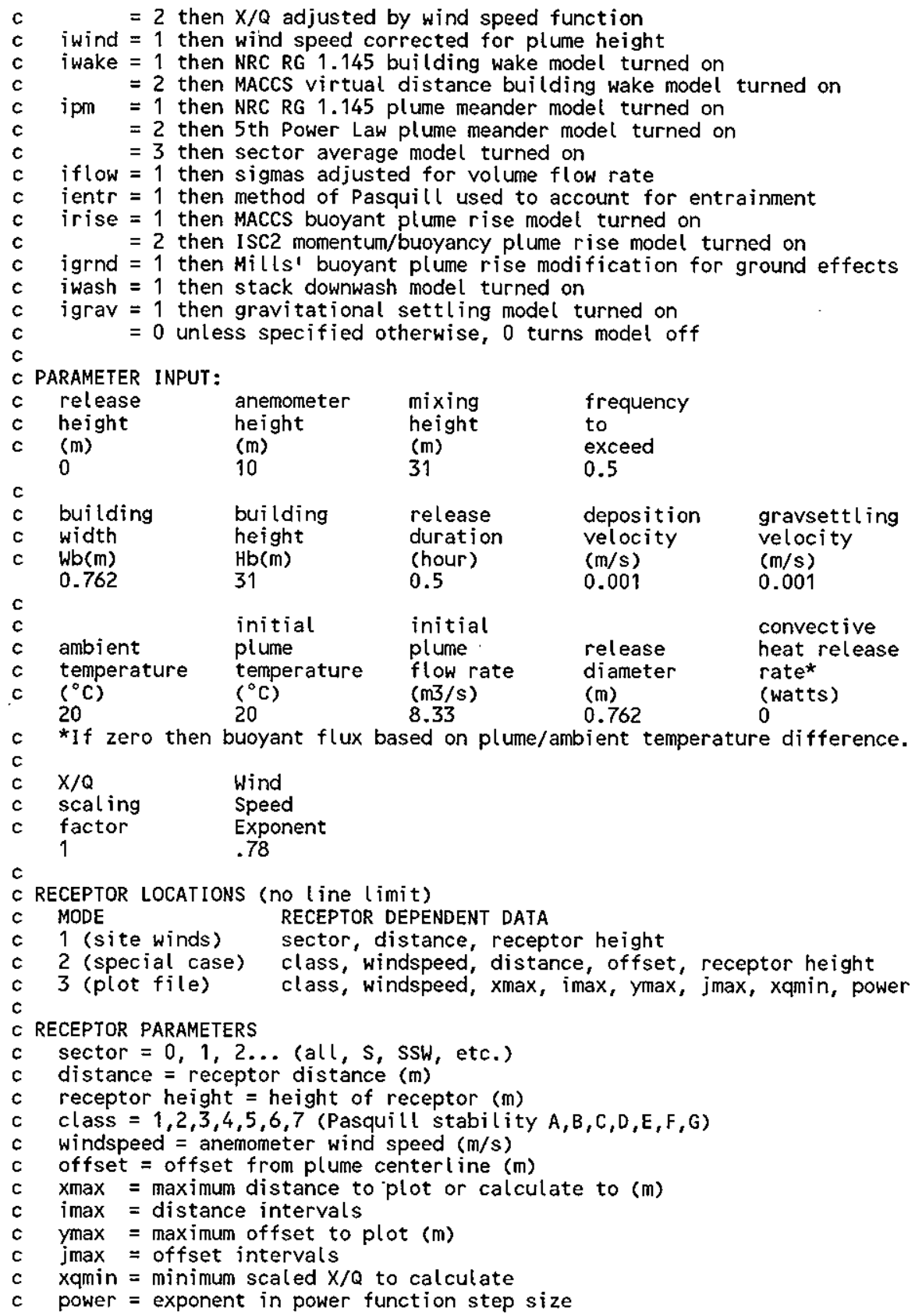

\section{Cold Vacuum Drying Facility, Heating, Ventilating, and Air Conditioning Stack - Less than 0.5 Hour - Sector Maximum 99.5\%}

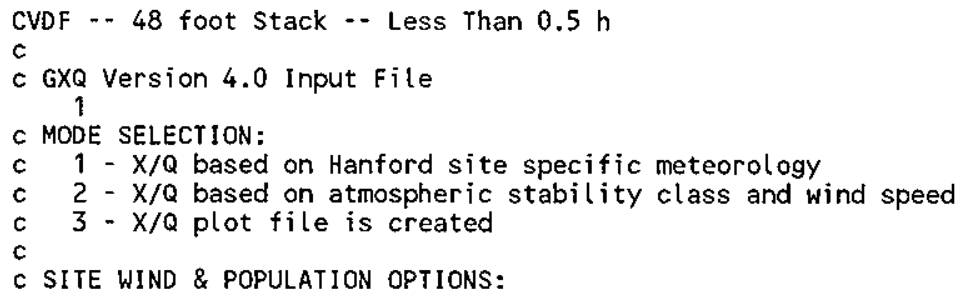









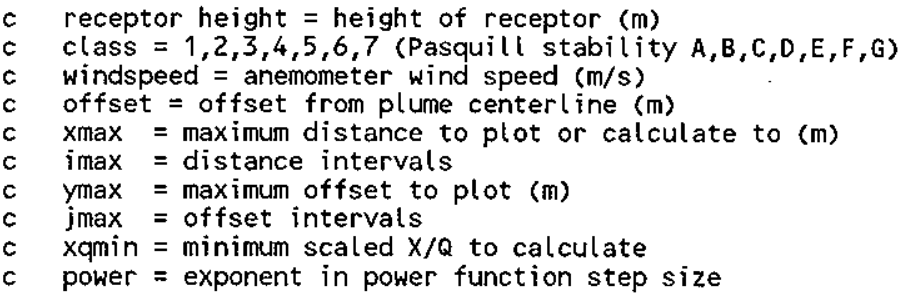

\section{Cold Vacuum Drying Facility, Heating, Ventilating, and Air Conditioning Stack - 0.5 to 2 Hours - Sector Maximum $99.5 \%$}

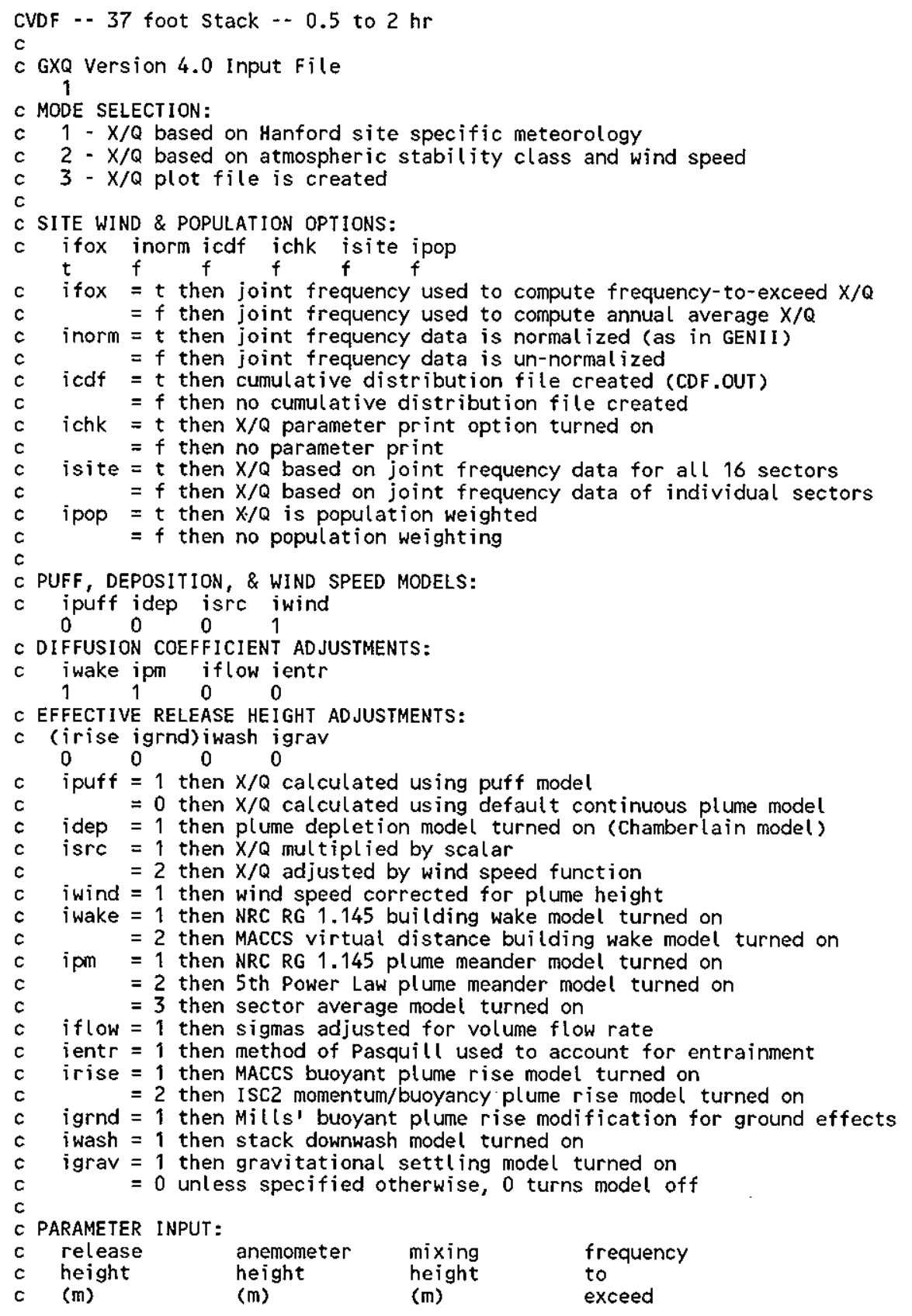


HNF-SD-SNF-TI-059 REV 2

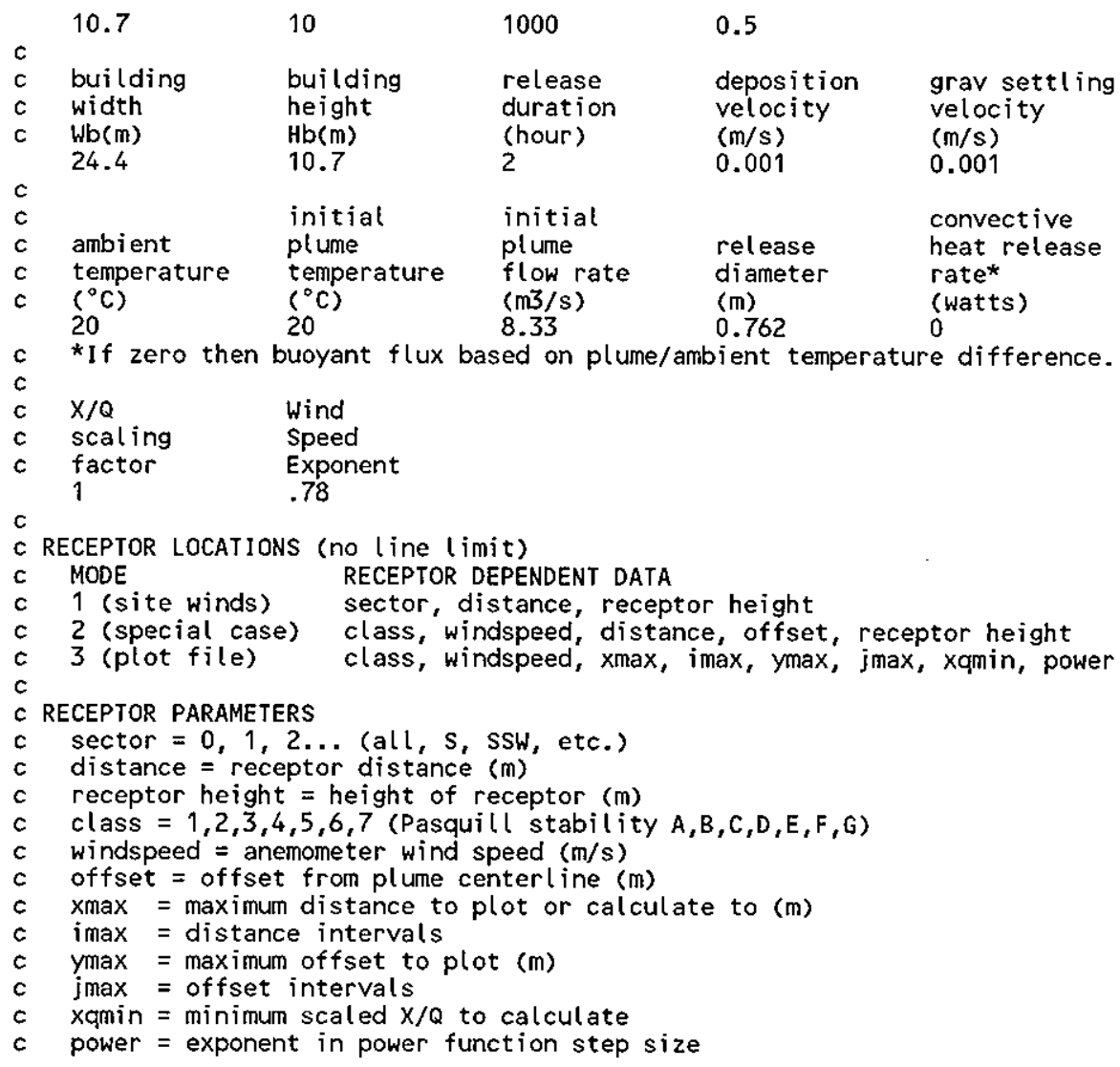

\section{Cold Vacuum Drying Facility, Heating, Ventilating, and Air Conditioning Stack - Annual Average - Sector Maximum}

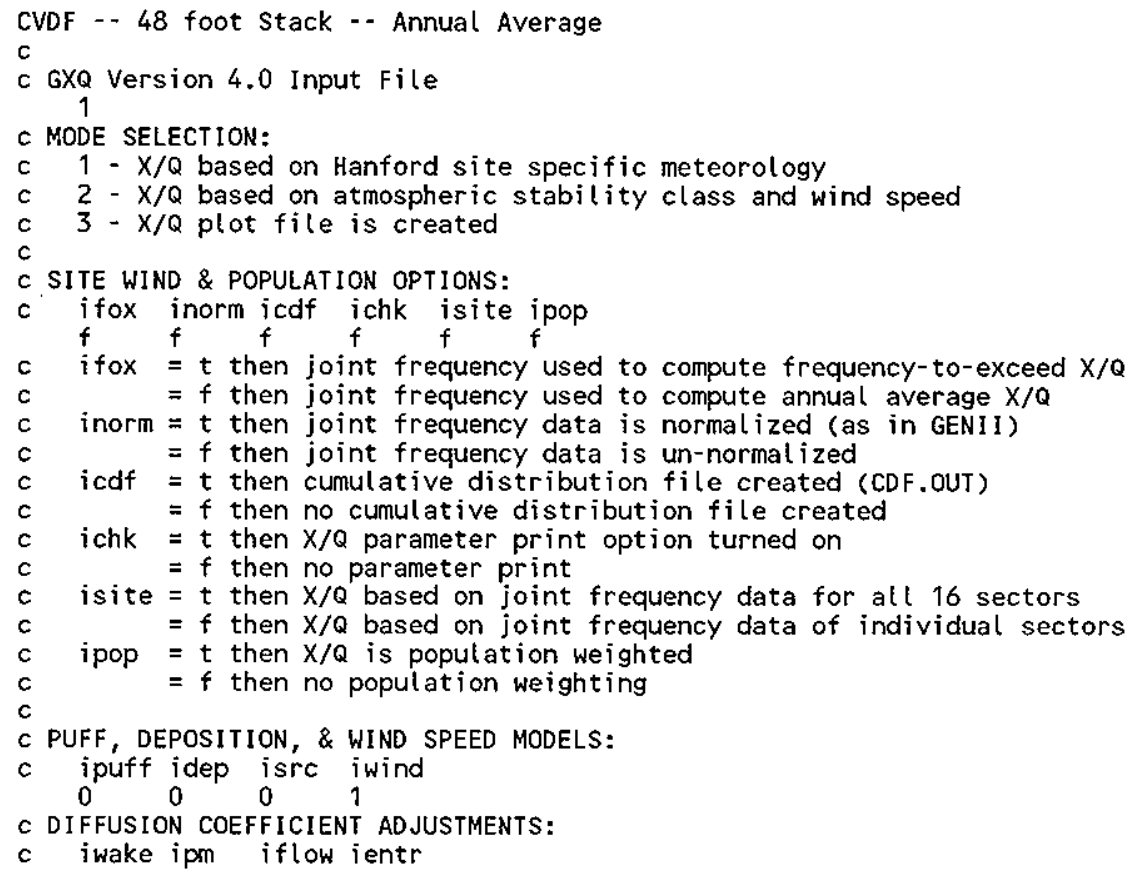




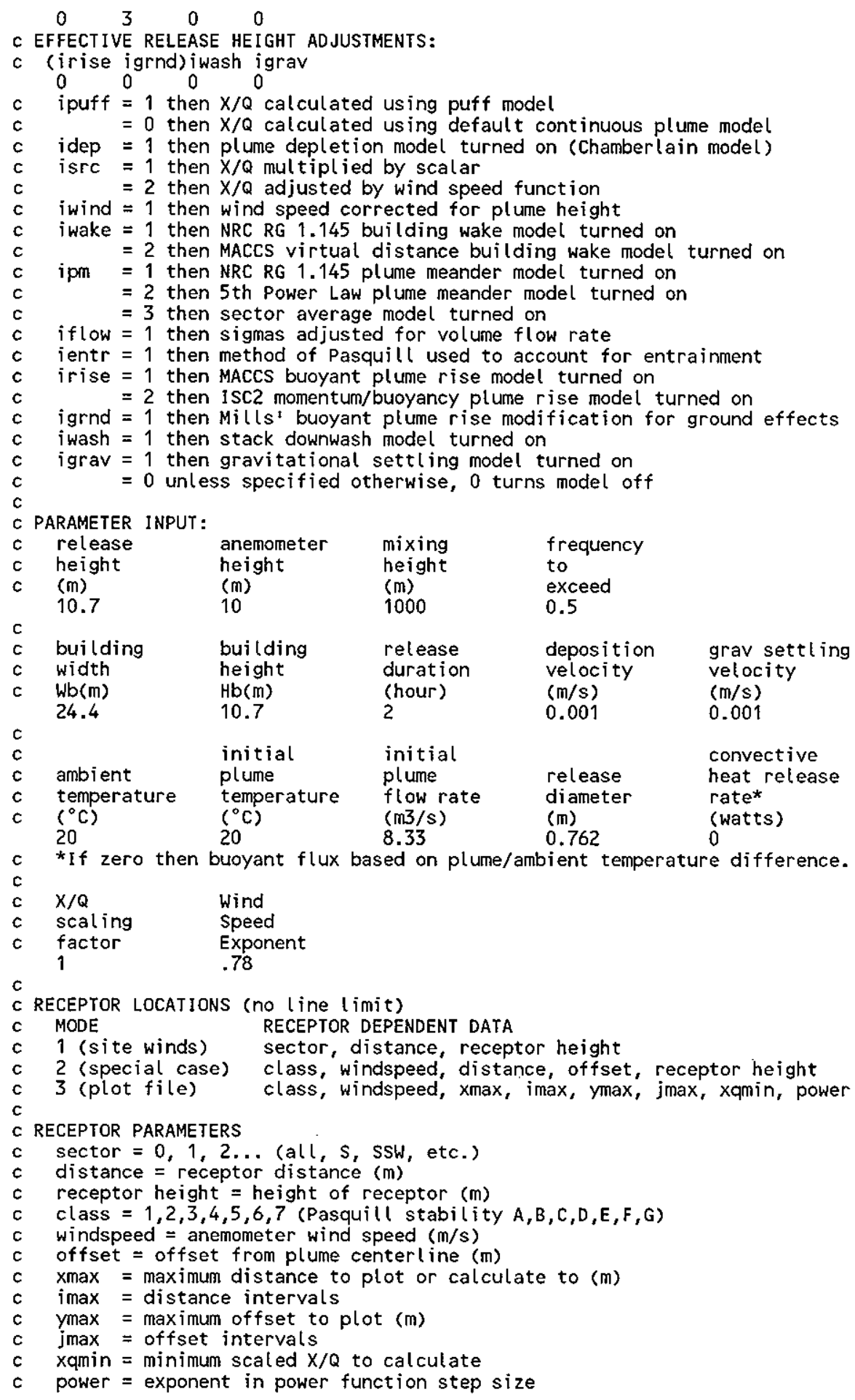




\section{GXQ Input for Cold Vacuum Drying Facility Receptor Distances and Elevations}

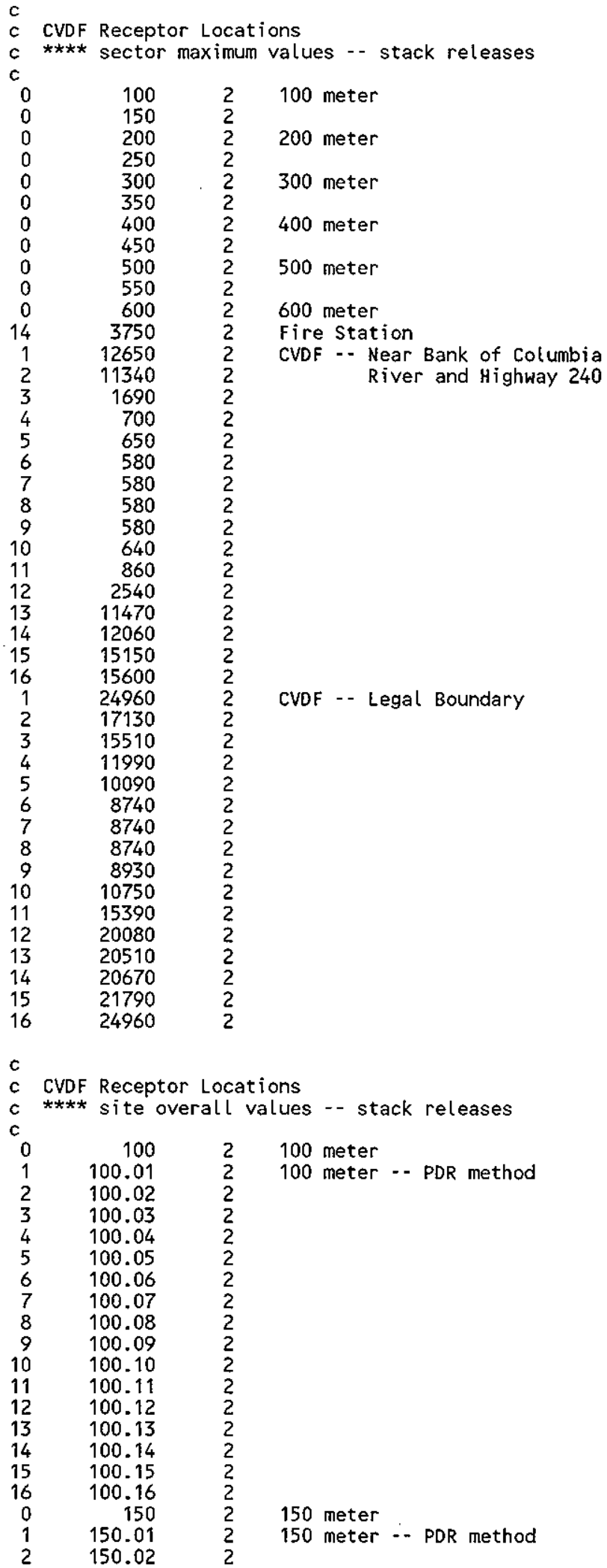




\section{HNF-SD-SNF-TI-059 REV 2}

150.03

150.04

150.05

150.06

150.07

150.08

150.09

150.10

150.11

150.12

150.13

150.14

150.15

150.16

200

200.01

200.02

200.03

200.04

200.05

200.06

200.07

200.08

200.09

200.10

200.11

200.12

200.13

200.14

200.15

200.16

250

250.01

250.02

250.03

250.04

250.05

250.06

250.07

250.08

250.09

250.10

250.11

250.12

250.13

250.14

250.15

250.16

300

300.01

300.02

300.03

300.04

300.05

300.06

300.07

300.08

300.09

300.10

300.11

300.12

300.13

300.14

300.15

300.16

350

350.01

350.02

350.03

350.04

350.05

350.06

350.07

350.08

350.09

350.10
200 meter

200 meter -- PDR method

250 meter

250 meter -- PDR method

300 meter

300 meter -- PDR method

350 meter

350 meter -- PDR method 
HNF-SD-SNF-TI-059 REV 2

350.11

350.12

350.13

350.14

350.15

350.16

400

400.01

400.02

400.03

400.04

400.05

400.06

400.07

400.08

400.09

400.10

400.11

400.12

400.13

400.14

400.15

400.16

450

450.01

450.02

450.03

450.04

450.05

450.06

450.07

450.08

450.09

450.10

450.11

450.12

450.13

450.14

450.15

450.16

500

500.01

500.02

500.03

500.04

500.05

500.06

500.07

500.08

500.09

500.10

500.11

500.12

500.13

500.14

500.15

500.16

550

550.01

550.02

550.03

550.04

550.05

550.06

550.07

550.08

550.09

550.10

550.11

550.12

550.13

550.14

550.15

550.16

600

600.01

400 meter

400 meter -- PDR method

450 meter

450 meter -- PDR method

500 meter

500 meter - - PDR method

550 meter

550 meter -- PDR method

600 meter

600 meter -- PDR method 
HNF-SD-SNF-TI-059 REV 2

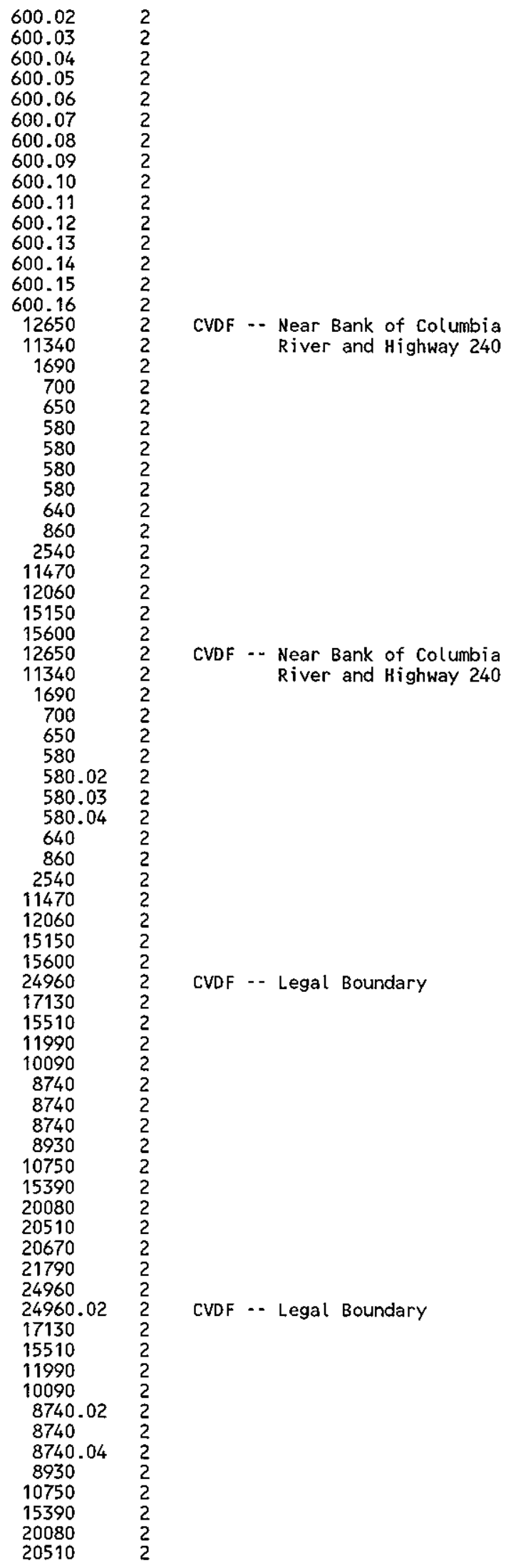


HNF-SD-SNF-TI-059 REV 2

$\begin{array}{lll}14 & 20670 & 2 \\ 15 & 21790 & 2 \\ 16 & 24960 & 2\end{array}$

Note: The GXQ inputs for overall site X/Q are identical to the above except that the "isite" flag is " $t$ " and the "frequency to exceed" is changed from 0.5 to 5.0. An example output file is shown below.

Cold Vacuum Drying Facility, Heating, Ventilating, and Air Conditioning Stack - Fumigation - Overall Site 95\%

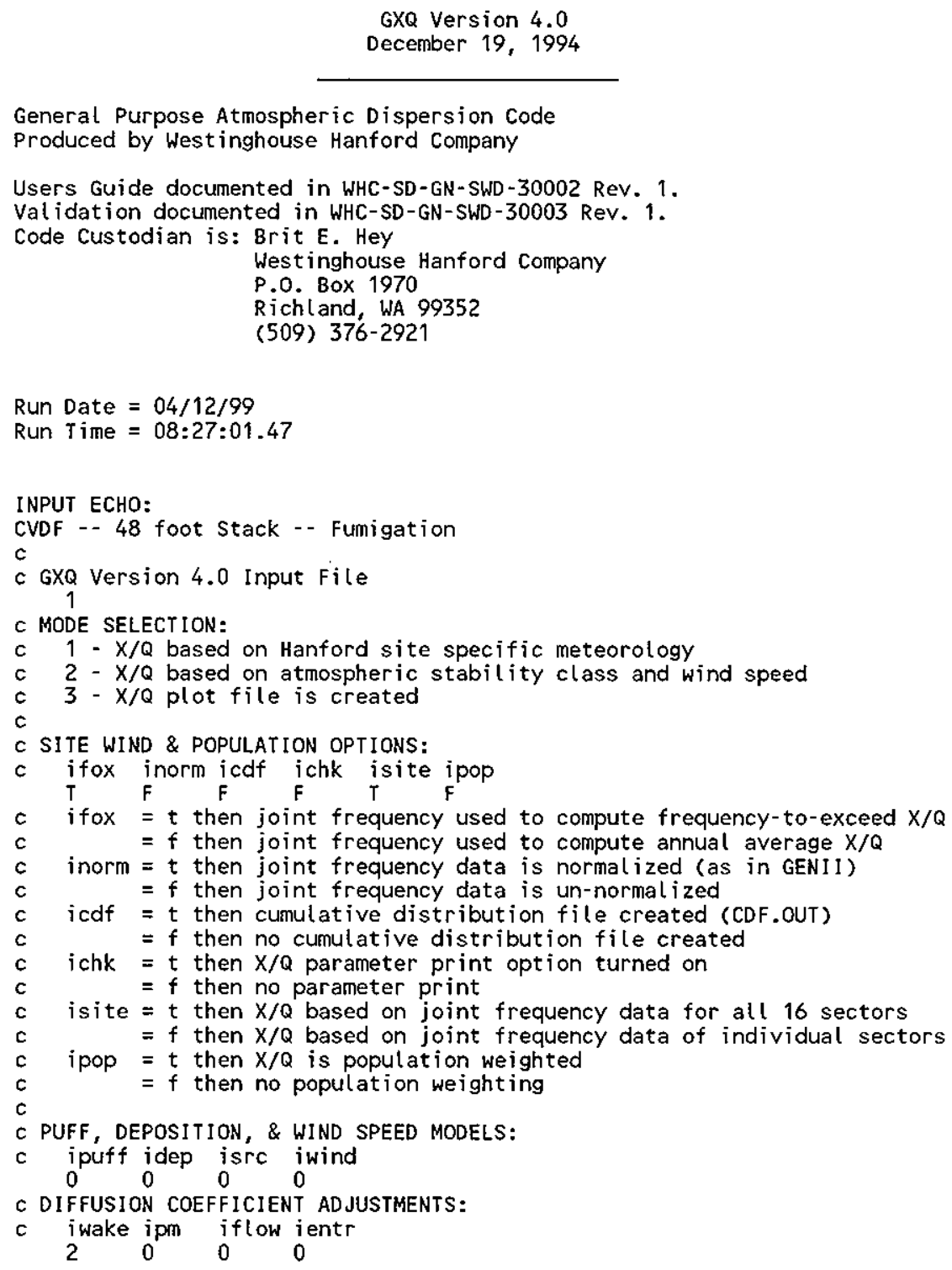




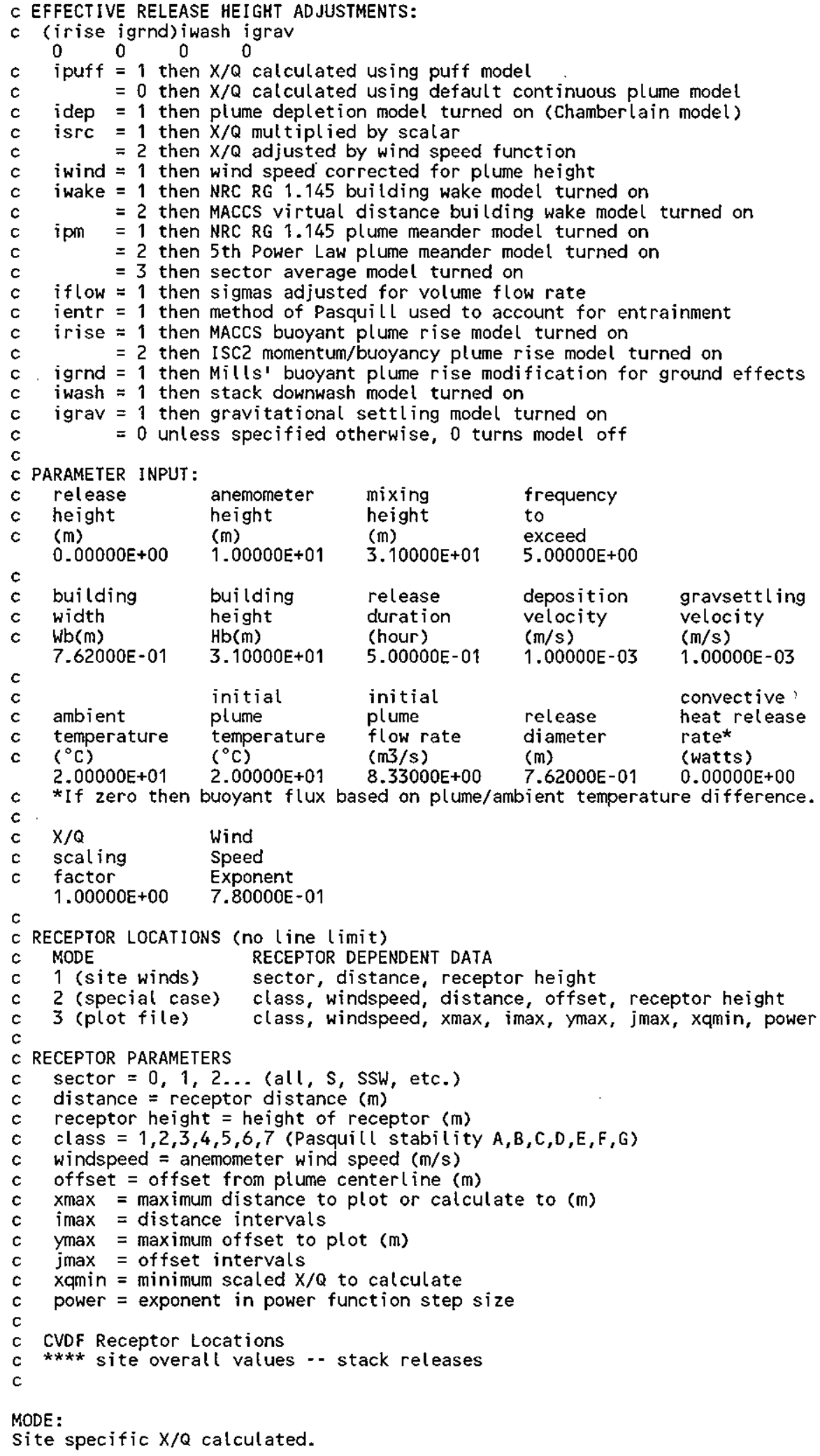

LOGICAL CHOICES:

Joint frequency used to calculate $X / Q$ based on frequency of exceedance. No normalization of joint frequency. 
$X / Q$ calculated for overall site.

MODELS SELECTED:

MACCS Virtual source building wake model selected.

Default Gaussian plume model selected.

WARNING/ERROR MESSAGES:

JOINT FREQUENCY DATA:

$100 \mathrm{~N}$ AREA - $10 \mathrm{M}$ - Pasquill A - G (1983 - 1991 Average)

Created $8 / 26 / 92$ KR

CVDF -- 48 foot Stack -- Fumigation

\begin{tabular}{|c|c|c|c|c|c|c|c|c|}
\hline SECTOR & $\begin{array}{l}\text { DISTANCE } \\
(\mathrm{m})\end{array}$ & $\begin{array}{c}\text { RECEPT } \\
\text { HEIGHT } \\
(m)\end{array}$ & $\begin{array}{l}\text { SECT. } \\
\text { FREQ. } \\
(\%)\end{array}$ & POPULATION & $\begin{array}{l}\text { TOTAL } \\
\text { POPULATION } \\
\text { SCALED } \\
X / Q \\
(\mathrm{~S} / \mathrm{mB})\end{array}$ & $\begin{array}{l}\text { AVERAGE } \\
\text { INDIVIDUAL } \\
\text { SCALED } \\
X / Q \\
(s / \mathrm{m} 3)\end{array}$ & $\begin{array}{l}\text { ATM. } \\
\text { STAB. } \\
\text { CLASS }\end{array}$ & $\begin{array}{l}\text { WIND } \\
\text { SPEED } \\
(\mathrm{m} / \mathrm{s})\end{array}$ \\
\hline $\begin{array}{l}A L L \\
A L L \\
A L L \\
A L L \\
A L L \\
A L L \\
A L L \\
A L L \\
A L L \\
A L L \\
A L L \\
A L L \\
A L L \\
A L L \\
A L L \\
A L L \\
A L L \\
A L L \\
A L L \\
A L L \\
A L L \\
A L L \\
A L L \\
A L L \\
A L L \\
A L L\end{array}$ & $\begin{array}{l}100 \\
100 \\
150 \\
150 \\
200 \\
200 \\
250 \\
250 \\
300 \\
300 \\
350 \\
350 \\
400 \\
400 \\
450 \\
450 \\
500 \\
500 \\
550 \\
550 \\
600 \\
600 \\
15600 \\
15600 \\
24960 \\
24960\end{array}$ & $\begin{array}{l}2 \\
2 \\
2 \\
2 \\
2 \\
2 \\
2 \\
2 \\
2 \\
2 \\
2 \\
2\end{array}$ & $\begin{array}{l}99.80 \\
99.80 \\
99.80 \\
99.80 \\
99.80 \\
99.80 \\
99.80 \\
99.80 \\
99.80 \\
99.80 \\
99.80 \\
99.80 \\
99.80 \\
99.80 \\
99.80 \\
99.80 \\
99.80 \\
99.80 \\
99.80 \\
99.80 \\
99.80 \\
99.80 \\
99.80 \\
99.80 \\
99.80 \\
99.80\end{array}$ & $\begin{array}{l}1 \\
1 \\
1 \\
1 \\
1 \\
1 \\
1 \\
1 \\
1 \\
1 \\
1 \\
1 \\
1 \\
1 \\
1 \\
1 \\
1 \\
1 \\
1 \\
1 \\
1 \\
1 \\
1 \\
1 \\
1 \\
1\end{array}$ & $\begin{array}{l}6.24 \mathrm{E}-03 \\
4.85 \mathrm{E}-03 \\
4.29 \mathrm{E}-03 \\
3.28 \mathrm{E}-03 \\
3.27 \mathrm{E}-03 \\
2.47 \mathrm{E}-03 \\
2.64 \mathrm{E}-03 \\
1.97 \mathrm{E}-03 \\
2.21 \mathrm{E}-03 \\
1.63 \mathrm{E}-03 \\
1.90 \mathrm{E}-03 \\
1.39 \mathrm{E}-03 \\
1.66 \mathrm{E}-03 \\
1.21 \mathrm{E}-03 \\
1.48 \mathrm{E}-03 \\
1.06 \mathrm{E}-03 \\
1.33 \mathrm{E}-03 \\
9.50 \mathrm{E}-04 \\
1.20 \mathrm{E}-03 \\
8.57 \mathrm{E}-04 \\
1.10 \mathrm{E}-03 \\
7.80 \mathrm{E}-04 \\
5.22 \mathrm{E}-04 \\
5.17 \mathrm{E}-04 \\
4.03 \mathrm{E}-05 \\
4.03 \mathrm{E}-05\end{array}$ & $\begin{array}{l}6.24 \mathrm{E}-03 \\
4.85 \mathrm{E}-03 \\
4.29 \mathrm{E}-03 \\
3.28 \mathrm{E}-03 \\
3.27 \mathrm{E}-03 \\
2.47 \mathrm{E}-03 \\
2.64 \mathrm{E}-03 \\
1.97 \mathrm{E}-03 \\
2.21 \mathrm{E}-03 \\
1.63 \mathrm{E}-03 \\
1.90 \mathrm{E}-03 \\
1.39 \mathrm{E}-03 \\
1.66 \mathrm{E}-03 \\
1.21 \mathrm{E}-03 \\
1.48 \mathrm{E}-03 \\
1.06 \mathrm{E}-03 \\
1.33 \mathrm{E}-03 \\
9.50 \mathrm{E}-04 \\
1.20 \mathrm{E}-03 \\
8.57 \mathrm{E}-04 \\
1.10 \mathrm{E}-03 \\
7.80 \mathrm{E}-04 \\
5.22 \mathrm{E}-04 \\
5.17 \mathrm{E}-04 \\
4.03 \mathrm{E}-05 \\
4.03 \mathrm{E}-05\end{array}$ & $\begin{array}{l}G \\
F \\
G \\
F \\
G \\
F \\
G \\
F \\
G \\
F \\
G \\
F \\
G \\
F \\
G \\
F \\
G \\
F \\
G \\
F \\
G \\
F \\
F \\
F \\
F \\
F\end{array}$ & $\begin{array}{l}0.89 \\
0.89 \\
0.89 \\
0.89 \\
0.89 \\
0.89 \\
0.89 \\
0.89 \\
0.89 \\
0.89 \\
0.89 \\
0.89 \\
0.89 \\
0.89 \\
0.89 \\
0.89 \\
0.89 \\
0.89 \\
0.89 \\
0.89 \\
0.89 \\
0.89 \\
0.89 \\
0.89 \\
0.89 \\
0.89\end{array}$ \\
\hline
\end{tabular}

\section{Canister Storage Building, Heating, Ventilating, and Air Conditioning Stack - Plume Rise Only}

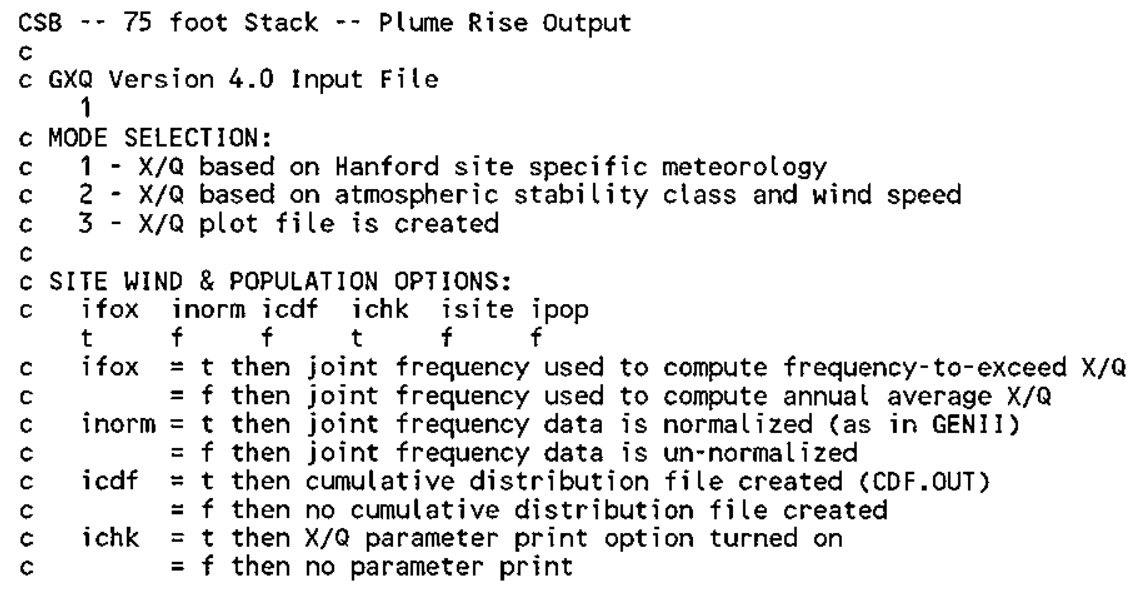




\section{DIFFUSION COEFFICIENT ADJUSTMENTS:}

C iwake ipm iflow ientr

$$
\begin{array}{llll}
\text { i wake ipm iflow ientr } \\
0 & 0 & 1
\end{array}
$$

c EFFECTIVE RELEASE HEIGHT ADJUSTMENTS:

c (irise igrnd) iwash igrav

$$
200
$$

ipuff $=1$ then $X / Q$ calculated using puff model

c $=0$ then $X / Q$ calculated using default continuous plume model

idep $=1$ then plume depletion model turned on (Chamberlain model)

isrc $=1$ then $X / Q$ multiplied by scalar

$=2$ then $X / Q$ adjusted by wind speed function

iwind $=1$ then wind speed corrected for plume height

iwake $=1$ then NRC RG 1.145 building wake model turned on

$=2$ then MACCS virtual distance building wake model turned on

ipm = 1 then NRC RG 1.145 plume meander model turned on

$=2$ then 5 th Power Law plume meander model turned on

$=3$ then sector average model turned on

iflow $=1$ then sigmas adjusted for volume flow rate

ientr $=1$ then method of Pasquill used to account for entrainment

irise $=1$ then MACCS buoyant plume rise model turned on

$=2$ then ISC2 momentum/buoyancy plume rise model turned on

igrnd $=1$ then Mills' buoyant plume rise modification for ground effects

$i$ wash $=1$ then stack downwash model turned on

igrav = 1 then gravitational settling model turned on

$=0$ unless specified otherwise, 0 turns model off

PARAMETER INPUT:

release anemometer mixing frequency

height height height to

$\begin{array}{lll}(\mathrm{m}) & (\mathrm{m}) & (\mathrm{m}) \\ 22.86 & 10 & 1000\end{array}$

c

$c$

c

building

width

Wb(m)

42.4

building

$\mathrm{Hb}(\mathrm{m})$

18.3

(hour)

1

initial

ambient

temperature temperature

$\left({ }^{\circ} \mathrm{C}\right)$

20

$\left({ }^{\circ} \mathrm{C}\right)$

20

\section{initial}

plume

flow rate

$(\mathrm{m} 3 / \mathrm{s})$

2. 12

0.5

*If zero then buoyant $f$ lux based on plume/ambient temperature difference.

$X / Q$

Wind

scaling Speed

factor Exponent

1

MODE

1 (site winds)
2 (special case)

(no line limit)

3 (plot file)

RECEPTOR DEPENDENT DATA

sector, distance, receptor height

class, windspeed, distance, offset, receptor height

RECEPTOR PARAMETERS

class, windspeed, xmax, imax, ymax, jmax, xqmin, power

sector $=0,1,2 \ldots$ (all, s, ssw, etc.)

distance $=$ receptor distance $(\mathrm{m})$

receptor height $=$ height of receptor $(\mathrm{m})$

class $=1,2,3,4,5,6,7$ (Pasquill stabil ity $A, B, C, D, E, F, G$ )

windspeed $=$ anemometer wind speed (m/s)

offset $=$ offset from plume centerline (m)

$x \max =$ maximum distance to plot or calculate to (m)

imax $=$ distance intervals

$y \max =$ maximum of fset to plot (m)

jmax $=$ offset intervals

Xqmin = minimum scaled $X / Q$ to calculate

power $=$ exponent in power function step size 
HNF-SD-SNF-TI-059 REV 2

$\begin{array}{lcccc}c & & & \\ c & \text { CVDF Plume } & \text { Rise } & \text { \& Elevated Wind Speeds } \\ c & 100 & 2 & 100 \text { meter }\end{array}$

Canister Storage Building, Heating, Ventilating, and Air Conditioning Stack - Fumigation - Sector Maximum 99.5\%

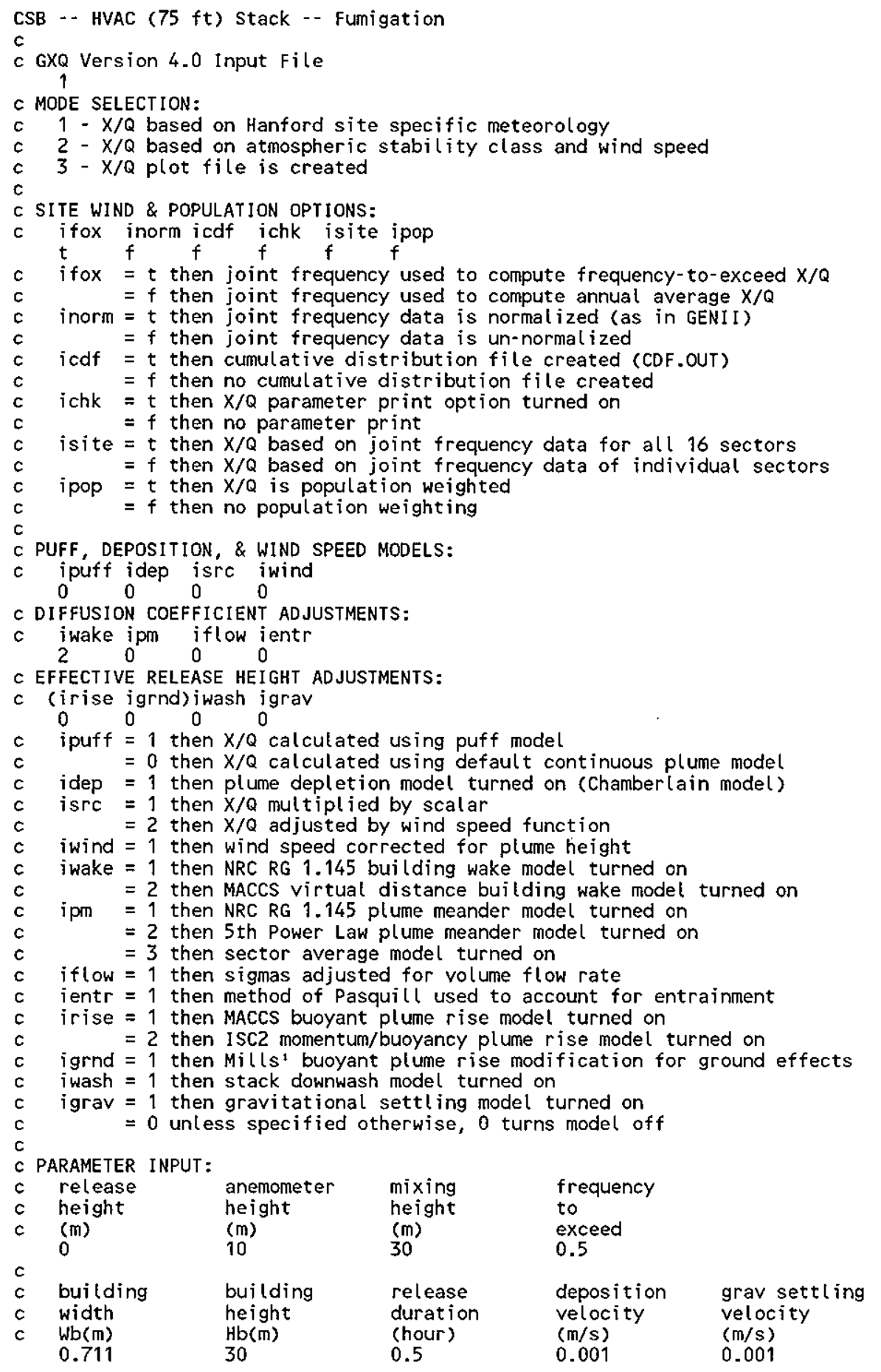


japow awnjd snonu!̨uos q jnefap 6u!sn pazejnojes $0 / \mathrm{X}$ uayt $0=$ jopoul $t$ tnd 6uisn pazejnojes $0 / X$ uəul $l=t+$ nd $l$ ?

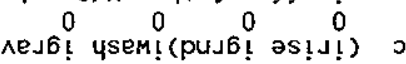

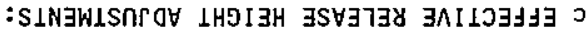

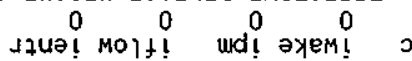
:SINJWISOR OY INGIJIJAJOJ NOISNAJIO ? putm! oss! dop! tfnd! 0

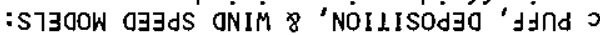

Gu!z46!әм uo!zejndod ou uәy $t=$

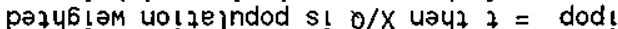

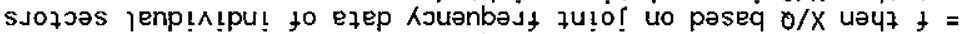


quisd Jәңәшеjed ou uәчł $t=$

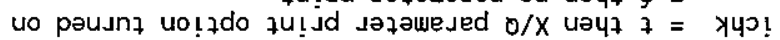

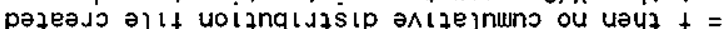
(100.100) pajeada allt U0!3nq pəz!)eusou-un s! eqep ksuənbəjt qu!o! uәyt $t=$ tpo!

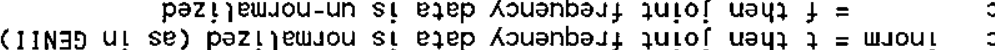

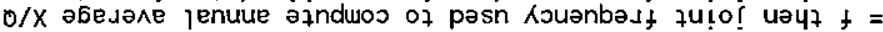

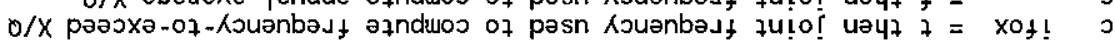

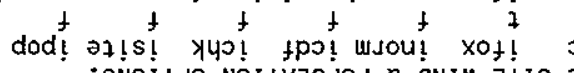
: SNOILdO NOIL

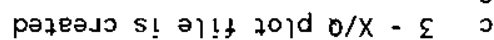

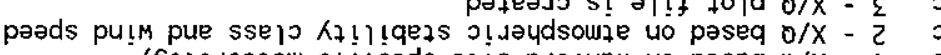
K60jolozjaW o!floads az!s pjogueh uo paseq $0 / \mathrm{X}$ - l : NOIIJJ7JS JOOW J 1

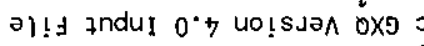

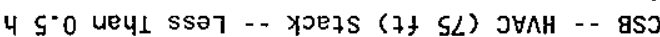

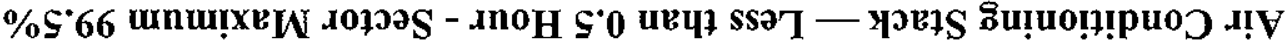


azıs dazs uo!zounf Jamod u! zuəuodxə = Jamod

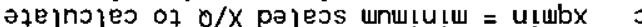 sjenjazu! zastjo = xeu! 0 (ui) $701 \mathrm{~d}$ of $70 s+70$ wnw! $\times$ ew $=$ xeuk 0 sjenjәzul әэuеjstp = хешl 0

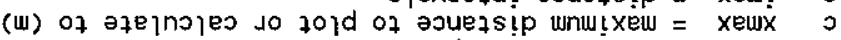 (U) au!) Jəquas aun

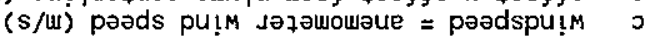

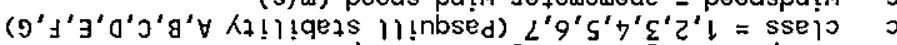

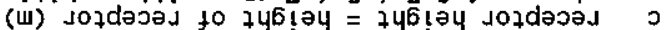 (Ui) aouezsip lozdəoaj= əouezsip 0

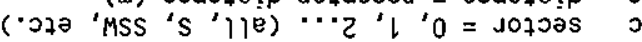

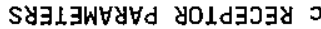

Jamod 'ulubx 'xeur 'xeuk 'xew! 'xeurx 'pazdspu!̣ 'ssejo



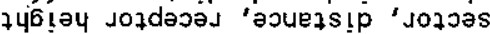
$\forall \perp \forall O \perp N 30 N \exists d \exists O$ YOL

(7)แ!l (a) $! f 70$ ) $\varepsilon$ ग (әseo jelozds) $z$ כ (spu!m $\partial+! s) l \quad 0$ JoOW 0$$
8 L^{\circ}
$$

7uavodxy jozael pards Gu!jeos 0

puṭ $0 / X \quad 2$

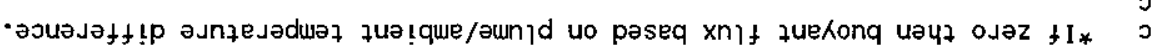

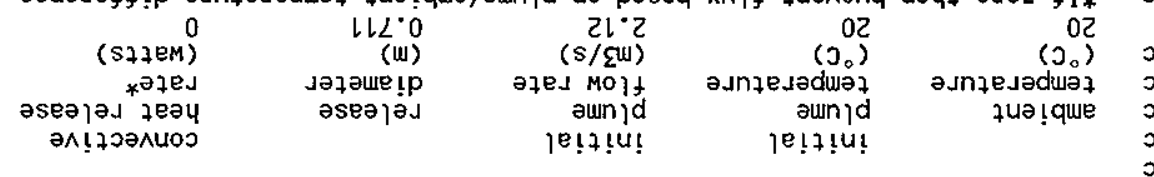




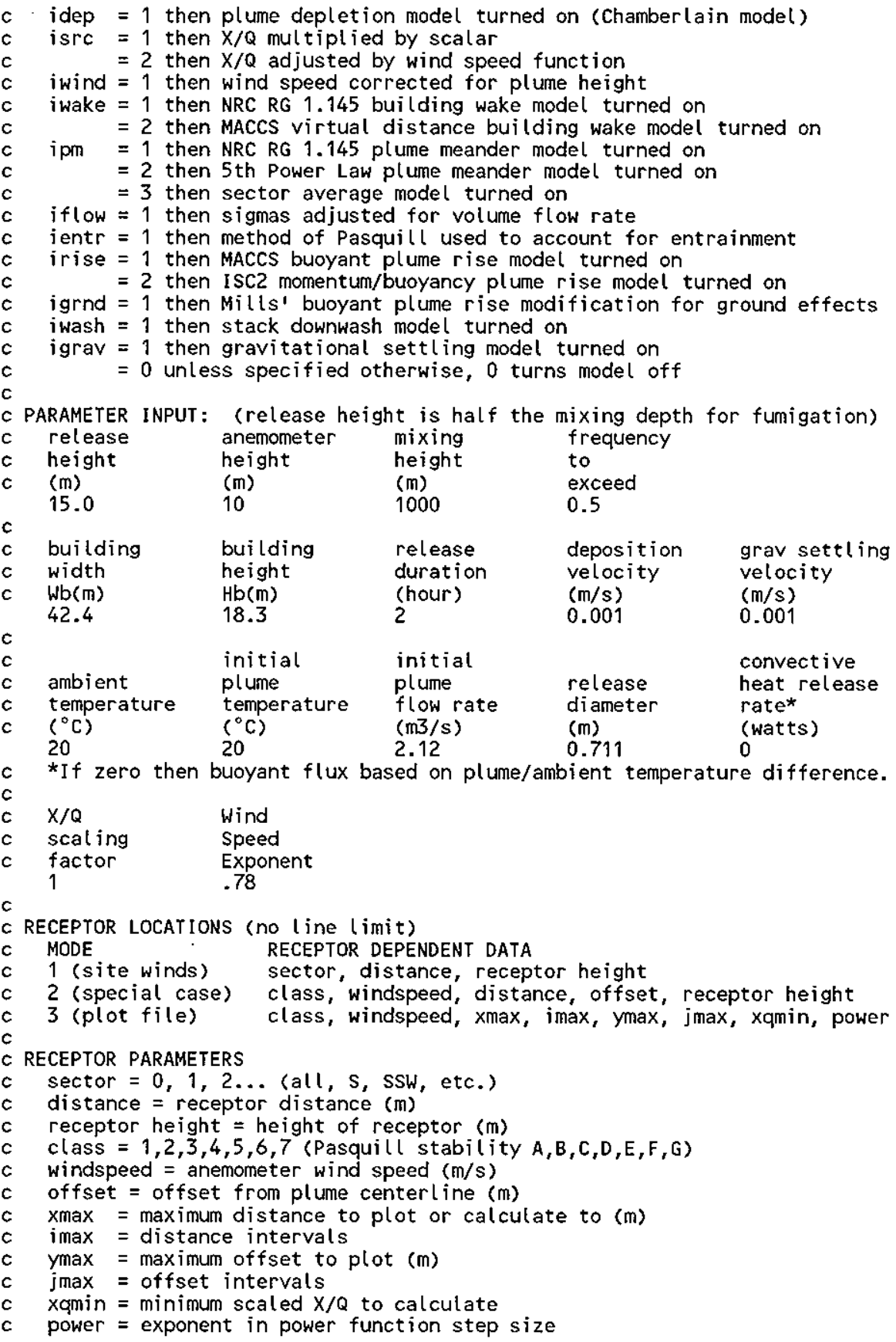

\section{Canister Storage Building, Heating, Ventilating, and} Air Conditioning Stack - 0.5 to 2 Hours - Sector Maximum 99.5\%

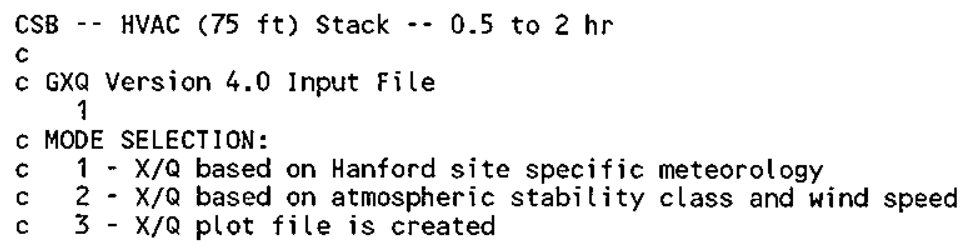


c SITE WIND \& POPULATION OPTIONS:

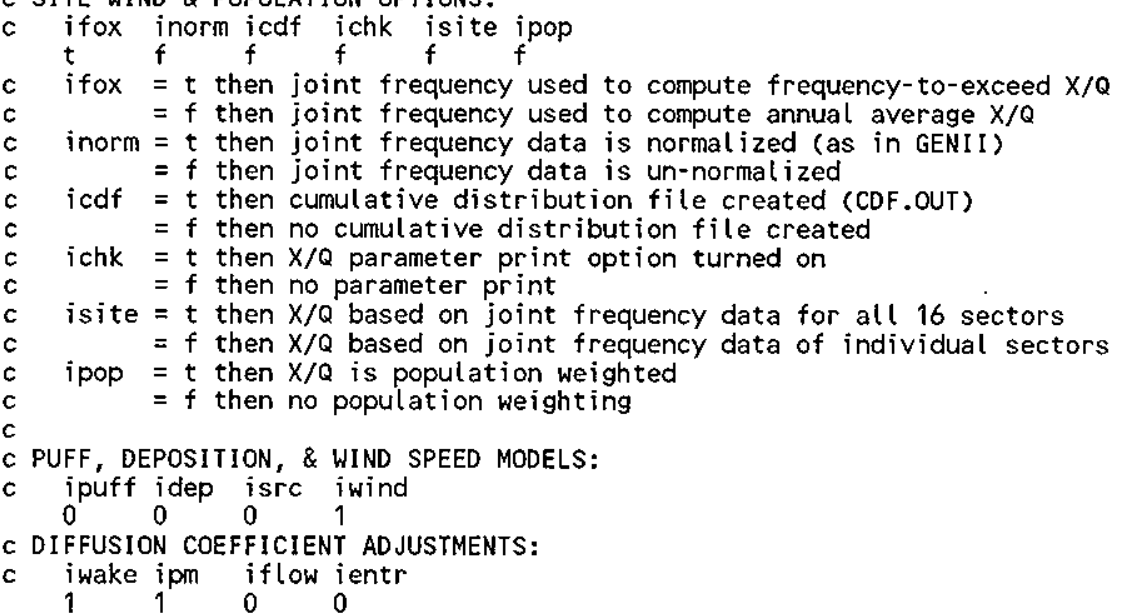

C EFFECTIVE RELEASE HEIGHT ADJUSTMENTS:

c (irise igrnd)iwash igrav

$\begin{array}{llll}0 & 0 & 0 & 0\end{array}$

jpuff $=1$ then $X / Q$ calculated using puff model

$=0$ then $X / Q$ calculated using default continuous plume model

idep $=1$ then plume depletion model turned on (Chamberlain model)

isrc $=1$ then $X / Q$ multiplied by scalar

$=2$ then $X / Q$ adjusted by wind speed function

iwind $=1$ then wind speed corrected for plume height

iwake $=1$ then NRC RG 1.145 building wake model turned on

$=2$ then MACCS virtual distance bujlding wake model turned on

ipm = 1 then NRC RG 1.145 plume meander model turned on

$=2$ then 5 th Power Law plume meander model turned on

$=3$ then sector average model turned on

iflow $=1$ then sigmas adjusted for volume $f$ low rate

ientr $=1$ then method of Pasquill used to account for entrainment

irise $=1$ then MACCS buoyant plume rise model turned on

$=2$ then ISC2 momentum/buoyancy plume rise model turned on

igrnd $=1$ then Mills' buoyant plume rise modification for ground effects

iwash $=1$ then stack downwash model turned on

igrav $=1$ then gravitational settling model turned on

$=0$ unless specified otherwise, 0 turns model of $f$

PARAMETER INPUT:

release anemometer mixing frequency

height

height height

(m) (m)

(m)

10

(m)

exceed

18.3

building

height

width

$\mathrm{Wb}(\mathrm{m})$

$\mathrm{Hb}(\mathrm{m})$

release

duration

(hour)

deposition

velocity

$(\mathrm{m} / \mathrm{s})$

0.001

grav settling

18.3

2

initial initial

ambient

temperature

temperature flow rate

$\left({ }^{\circ} \mathrm{C}\right)$

$\left({ }^{\circ} \mathrm{C}\right)$

20

(m3/s)

2. 12

release

diameter

(m)

0.711

ocity

$(\mathrm{m} / \mathrm{s})$

0.001

convective

heat release

rate*

(watts)

0

*If zero then buoyant flux based on plume/ambient temperature difference.

$X / Q \quad$ Wind

scaling Speed

factor Exponent

$1 \quad .78$

c RECEPTOR LOCATIONS (no line limit)

MODE RECEPTOR DEPENDENT DATA

1 (site winds)

sector, distance, receptor height

2 (special case) class, windspeed, distance, offset, receptor height

3 (plot $f i l e$ ) class, windspeed, $x \max , i \max , y \max$, jmax, xqmin, power

C RECEPTOR PARAMETERS 


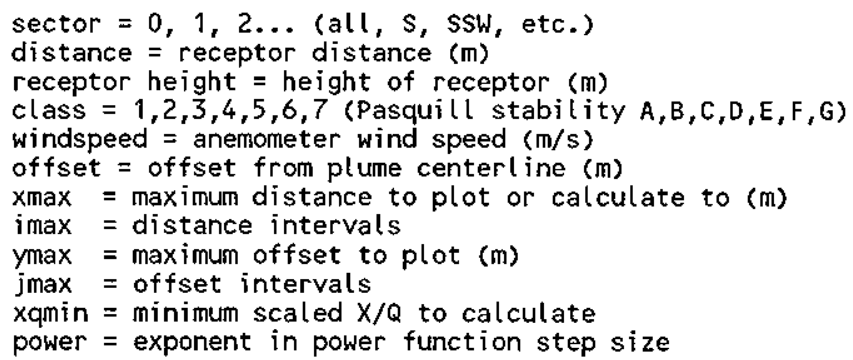

Canister Storage Building, Heating, Ventilating, and Air Conditioning Stack - Annual Average - Sector Maximum






\section{HNF-SD-SNF-TI-059 REV 2}

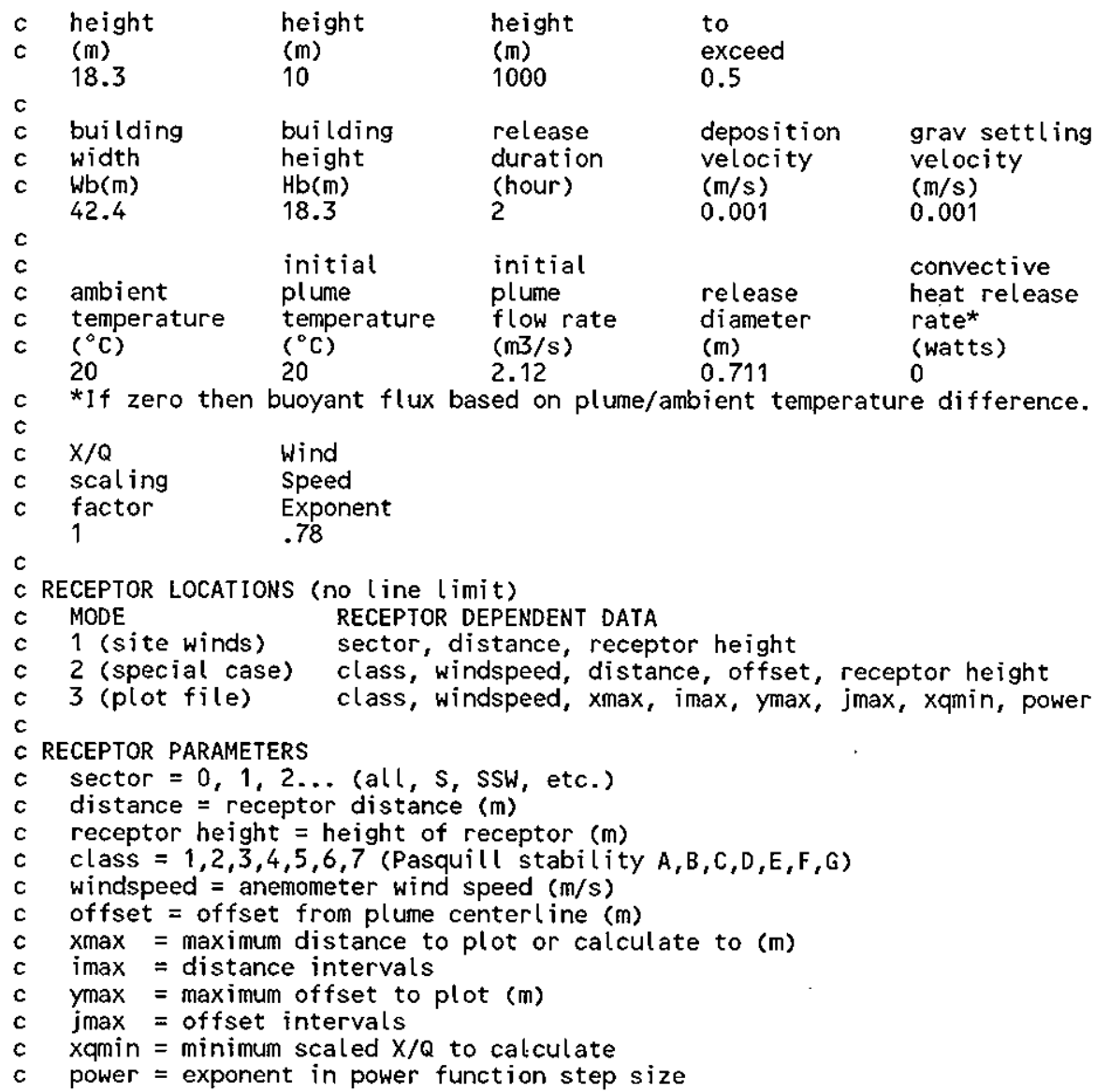




\section{GXQ Input for Canister Storage Building Receptor Distances and Elevations}

c

CSB Receptor Locations

$\star \star \star * *$ sector maximum values -- stack releases

150

200

250

300

350

400

450

500

550

600

7830

7830

7830

7830

9280

10510

11250

11250

11250

12750

12670

12670

12670

14230

11070

8490

16260

16260

16260

17910

18400

18400

18870

19450

19450

20390

17540

17390

17390

17390

20630

18830

100 meter

200 meter

300 meter

400 meter

500 meter

600 meter

CSB - - Near Bank of Columbia

River and Highway 240

CSB -- Legal Boundary

CSB Receptor Locations

**** site overall values -- stack releases

$\begin{array}{rr}100 & 2 \\ 100.01 & 2 \\ 100.02 & 2 \\ 100.03 & 2 \\ 100.04 & 2 \\ 100.05 & 2 \\ 100.06 & 2 \\ 100.07 & 2 \\ 100.08 & 2 \\ 100.09 & 2 \\ 100.10 & 2 \\ 100.11 & 2 \\ 100.12 & 2 \\ 100.13 & 2 \\ 100.14 & 2 \\ 100.15 & 2 \\ 100.16 & 2 \\ 150 & 2 \\ 150.01 & 2 \\ 150.02 & 2\end{array}$

100 meter

100 meter -- PDR method

150 meter

150 meter -- PDR method 


\section{HNF-SD-SNF-TI-059 REV 2}

150.03

150.04

150.05

150.06

150.07

150.08

150.09

150.10

150.11

150.12

150.13

150.14

150.15

150.16

200

200.01

200.02

200.03

200.04

200.05

200.06

200.07

200.08

200.09

200.10

200.11

200.12

200.13

200.14

200.15

200.16

250

250.01

250.02

250.03

250.04

250.05

250.06

250.07

250.08

250.09

250.10

250.11

250.12

250.13

250.14

250.15

250.16

300

300.01

300.02

300.03

300.04

300.05

300.06

300.07

300.08

300.09

300.10

300.11

300.12

300.13

300.14

300.15

300.16

350

350.01

350.02

350.03

350.04

350.05

350.06

350.07

350.08

350.09

350.10
200 meter

200 meter - - PDR method

250 meter

250 meter -- PDR method

300 meter

300 meter -- PDR method

350 meter

350 meter -- PDR method 
HNF-SD-SNF-TI-059 REV 2

350.11

350.12

350.13

350.14

350.15

350.16

400

400.01

400.02

400.03

400.04

400.05

400.06

400.07

400.08

400.09

400.10

400.11

400.12

400.13

400.14

400.15

400.16

450

450.01

450.02

450.03

450.04

450.05

450.06

450.07

450.08

450.09

450.10

450.11

450.12

450.13

450.14

450.15

450.16

500

500.01

500.02

$500: 03$

500.04

500.05

500.06

500.07

500.08

500.09

500.10

500.11

500.12

500.13

500.14

500.15

500.16

550

550.01

550.02

550.03

550.04

550.05

550.06

550.07

550.08

550.09

550.10

550.11

550.12

550.13

550.14

550.15

550.16

600

600.01
400 meter

400 meter - - PDR method

450 meter

450 meter -. PDR method

500 meter

500 meter - P PDR method

550 meter

550 meter -- PDR method

600 meter

600 meter -- PDR method 
HNF-SD-SNF-TI-059 REV 2

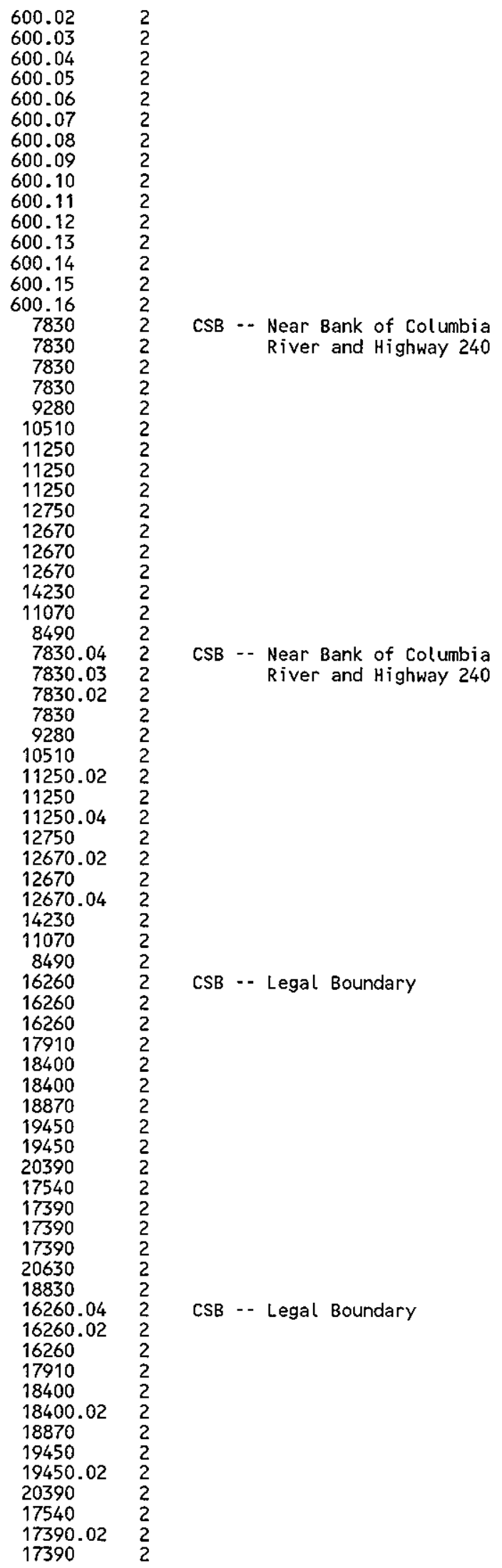


HNF-SD-SNF-TI-059 REV 2

$\begin{array}{lll}14 & 17390.04 & 2 \\ 15 & 20630 & 2 \\ 16 & 18830 & 2\end{array}$

Note: The GXQ inputs for overall site X/Q are identical to the above except that the "isite" flag is " $t$ " and the "frequency to exceed" is changed from 0.5 to 5.0. An example output file is shown below.

\section{Canister Storage Building, Heating, Ventilating, and Air Conditioning Stack - Fumigation - Overall Site 95\%}

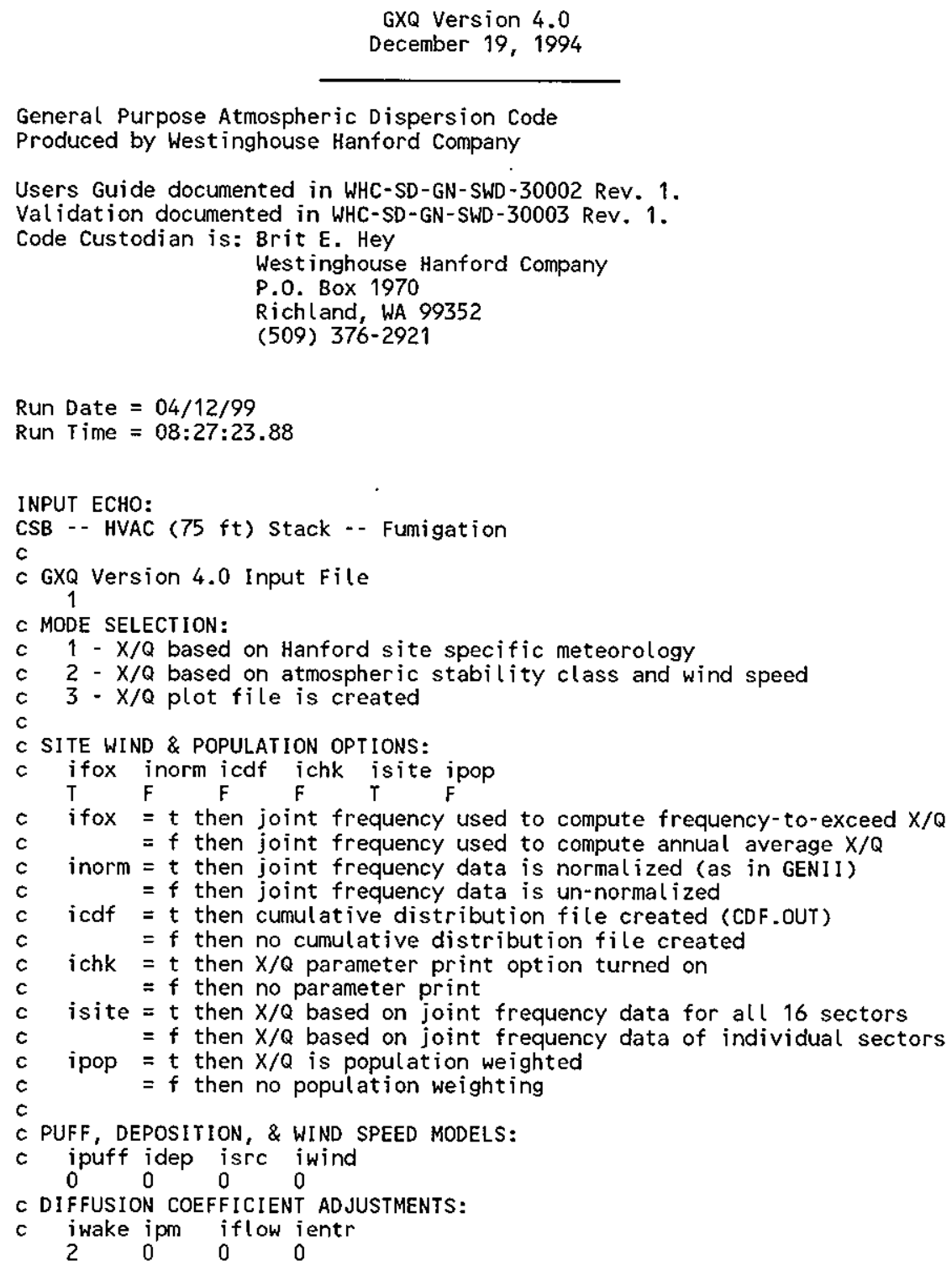




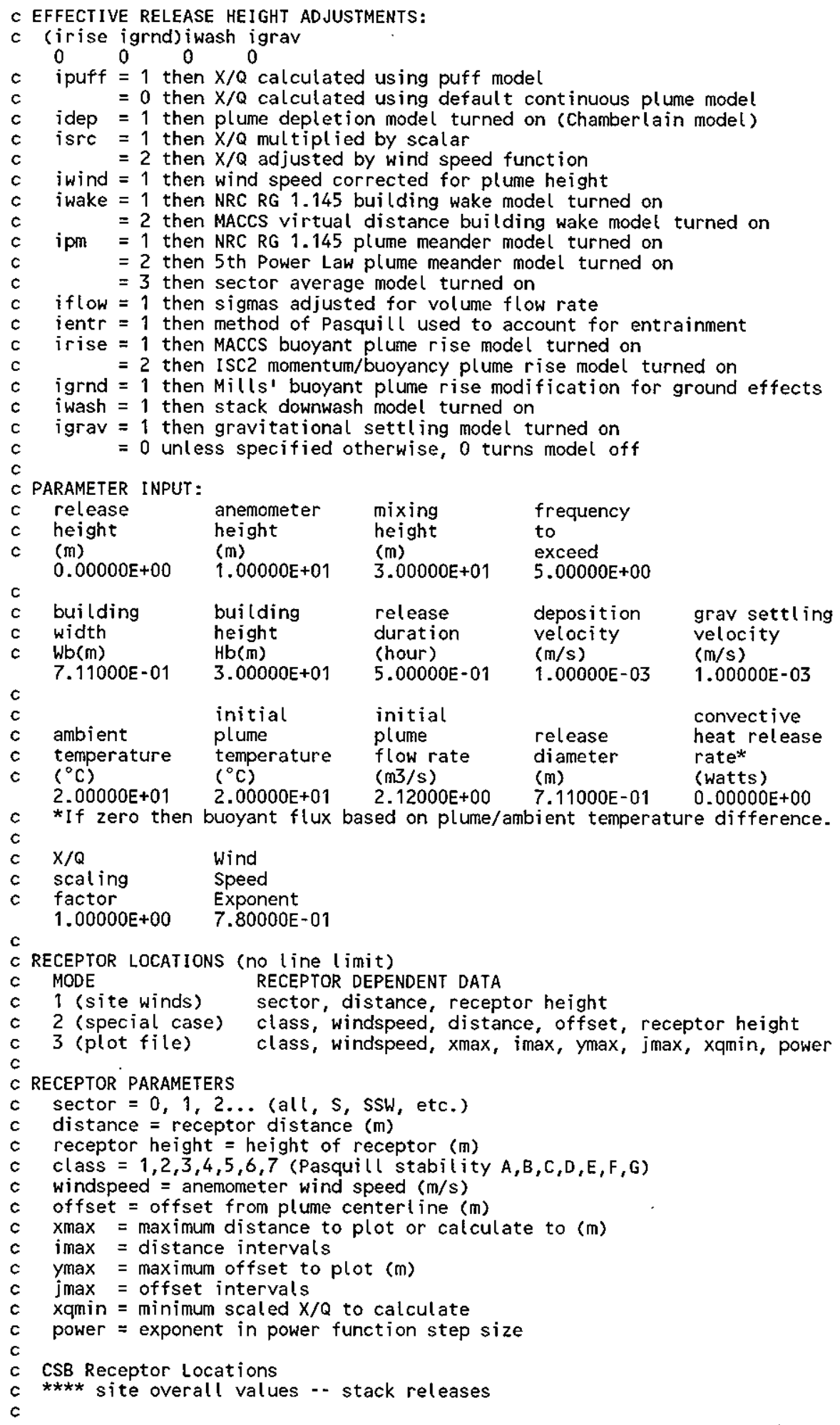

MODE:

Site specific $X / Q$ calculated.

LOGICAL CHOICES:

Joint frequency used to calculate $X / Q$ based on frequency of exceedance.

No normal ization of joint frequency. 


\section{HNF-SD-SNF-TI-059 REV 2}

$X / Q$ calculated for overall site.

MODELS SELECTED:

MACCS Virtual source building wake model selected.

Default Gaussian plume model selected.

WARNING/ERROR MESSAGES:

JOINT FREQUENCY DATA:

200 AREA (HMS) - $10 \mathrm{M}$ - Pasquill A - G (1983 - 1991 Average) Created 8/26/92 KR

CSB -- HVAC $(75 \mathrm{ft})$ stack -- Fumigation

\begin{tabular}{|c|c|c|c|c|c|c|c|c|}
\hline SECTOR & $\begin{array}{l}\text { DISTANCE } \\
(\mathrm{m})\end{array}$ & $\begin{array}{c}\text { RECEPT } \\
\text { HEIGHT } \\
(\mathrm{m})\end{array}$ & $\begin{array}{c}\text { SECT. } \\
\text { FREQ. } \\
(\%)\end{array}$ & POPULATION & $\begin{array}{l}\text { TOTAL } \\
\text { POPULATION } \\
\text { SCALED } \\
\text { X/Q } \\
(\mathrm{s} / \mathrm{m} 3)\end{array}$ & $\begin{array}{l}\text { AVERAGE } \\
\text { IND IVIDUAL } \\
\text { SCALED } \\
X / Q \\
(\mathrm{~s} / \mathrm{m3})\end{array}$ & $\begin{array}{l}\text { ATM. } \\
\text { STAB. } \\
\text { CLASS }\end{array}$ & $\begin{array}{l}\text { WIND } \\
\text { SPEED } \\
(\mathrm{m} / \mathrm{s})\end{array}$ \\
\hline $\begin{array}{l}\text { ALL } \\
\text { ALL } \\
\text { ALL } \\
\text { ALL } \\
\text { ALL } \\
\text { ALL } \\
\text { ALL } \\
\text { ALL } \\
\text { ALL } \\
\text { ALL } \\
\text { ALL } \\
\text { ALL } \\
\text { ALL } \\
\text { ALL } \\
\text { ALL } \\
\text { ALL } \\
\text { ALL } \\
\text { ALL } \\
\text { ALL } \\
\text { ALL } \\
\text { ALL } \\
\text { ALL } \\
\text { ALL } \\
\text { ALL } \\
\text { ALL } \\
\text { ALL }\end{array}$ & $\begin{array}{r}100 \\
100 \\
150 \\
150 \\
200 \\
200 \\
250 \\
250 \\
300 \\
300 \\
350 \\
350 \\
400 \\
400 \\
450 \\
450 \\
500 \\
500 \\
550 \\
550 \\
600 \\
600 \\
8490 \\
8490 \\
18830 \\
18830\end{array}$ & $\begin{array}{l}2 \\
2 \\
2 \\
2 \\
2 \\
2 \\
2 \\
2 \\
2 \\
2 \\
2 \\
2 \\
2 \\
2 \\
2 \\
2 \\
2 \\
2 \\
2 \\
2 \\
2 \\
2 \\
2 \\
2 \\
2 \\
2\end{array}$ & $\begin{array}{l}99.94 \\
99.94 \\
99.94 \\
99.94 \\
99.94 \\
99.94 \\
99.94 \\
99.94 \\
99.94 \\
99.94 \\
99.94 \\
99.94 \\
99.94 \\
99.94 \\
99.94 \\
99.94 \\
99.94 \\
99.94 \\
99.94 \\
99.94 \\
99.94 \\
99.94 \\
99.94 \\
99.94 \\
99.94 \\
99.94\end{array}$ & $\begin{array}{l}1 \\
1 \\
1 \\
1 \\
1 \\
1 \\
1 \\
1 \\
1 \\
1 \\
1 \\
1 \\
1 \\
1 \\
1 \\
1 \\
1 \\
1 \\
1 \\
1 \\
1 \\
1 \\
1 \\
1\end{array}$ & $\begin{array}{l}4.63 \mathrm{E}-03 \\
4.99 \mathrm{E}-03 \\
3.12 \mathrm{E}-03 \\
3.37 \mathrm{E}-03 \\
2.34 \mathrm{E}-03 \\
2.53 \mathrm{E}-03 \\
1.86 \mathrm{E}-03 \\
2.02 \mathrm{E}-03 \\
1.53 \mathrm{E}-03 \\
1.67 \mathrm{E}-03 \\
1.30 \mathrm{E}-03 \\
1.42 \mathrm{E}-03 \\
1.13 \mathrm{E}-03 \\
1.23 \mathrm{E}-03 \\
9.94 \mathrm{E}-04 \\
1.09 \mathrm{E}-03 \\
8.86 \mathrm{E}-04 \\
9.69 \mathrm{E}-04 \\
7.98 \mathrm{E}-04 \\
8.74 \mathrm{E}-04 \\
7.05 \mathrm{E}-04 \\
7.94 \mathrm{E}-04 \\
4.36 \mathrm{E}-05 \\
4.35 \mathrm{E}-05 \\
2.80 \mathrm{E}-05 \\
2.80 \mathrm{E}-05\end{array}$ & $\begin{array}{l}4.63 \mathrm{E}-03 \\
4.99 \mathrm{E}-03 \\
3.12 \mathrm{E}-03 \\
3.37 \mathrm{E}-03 \\
2.34 \mathrm{E}-03 \\
2.53 \mathrm{E}-03 \\
1.86 \mathrm{E}-03 \\
2.02 \mathrm{E}-03 \\
1.53 \mathrm{E}-03 \\
1.67 \mathrm{E}-03 \\
1.30 \mathrm{E}-03 \\
1.42 \mathrm{E}-03 \\
1.13 \mathrm{E}-03 \\
1.23 \mathrm{E}-03 \\
9.94 \mathrm{E}-04 \\
1.09 \mathrm{E}-03 \\
8.86 \mathrm{E}-04 \\
9.69 \mathrm{E}-04 \\
7.98 \mathrm{E}-04 \\
8.74 \mathrm{E}-04 \\
7.05 \mathrm{E}-04 \\
7.94 \mathrm{E}-04 \\
4.36 \mathrm{E}-05 \\
4.35 \mathrm{E}-05 \\
2.80 \mathrm{E}-05 \\
2.80 \mathrm{E}-05\end{array}$ & $\begin{array}{l}F \\
F \\
F \\
F \\
F \\
F \\
F \\
F \\
F \\
F \\
F \\
F \\
F \\
F \\
F \\
F \\
F \\
F \\
F \\
F \\
F \\
F \\
E \\
E \\
F \\
F\end{array}$ & $\begin{array}{l}0.89 \\
0.89 \\
0.89 \\
0.89 \\
0.89 \\
0.89 \\
0.89 \\
0.89 \\
0.89 \\
0.89 \\
0.89 \\
0.89 \\
0.89 \\
0.89 \\
0.89 \\
0.89 \\
0.89 \\
0.89 \\
0.89 \\
0.89 \\
0.89 \\
0.89 \\
0.89 \\
0.89 \\
0.89 \\
0.89\end{array}$ \\
\hline
\end{tabular}




\section{Canister Storage Building, Natural Circulation Stack - Plume Rise Only}

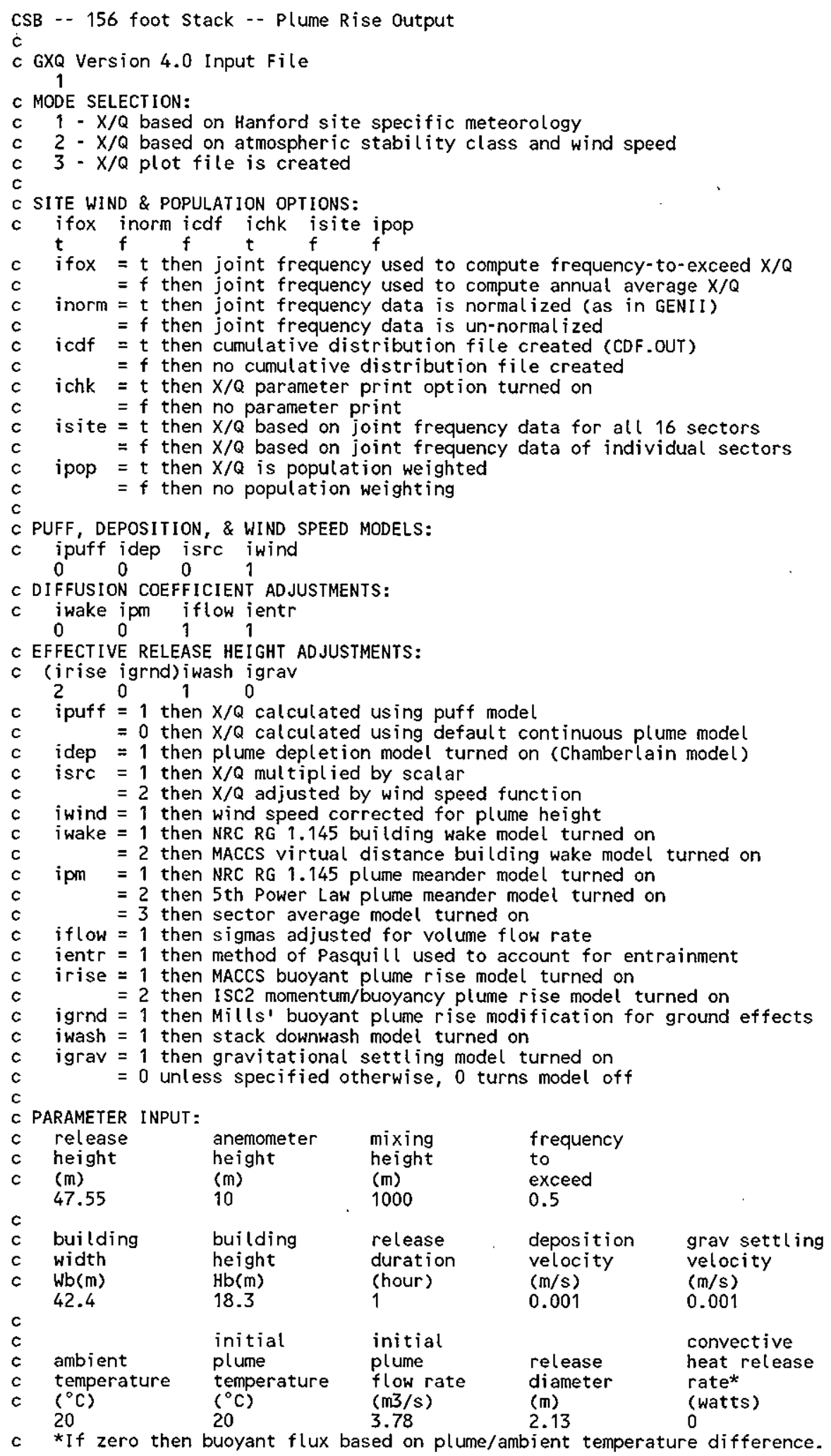




\section{HNF-SD-SNF-TI-059 REV 2}

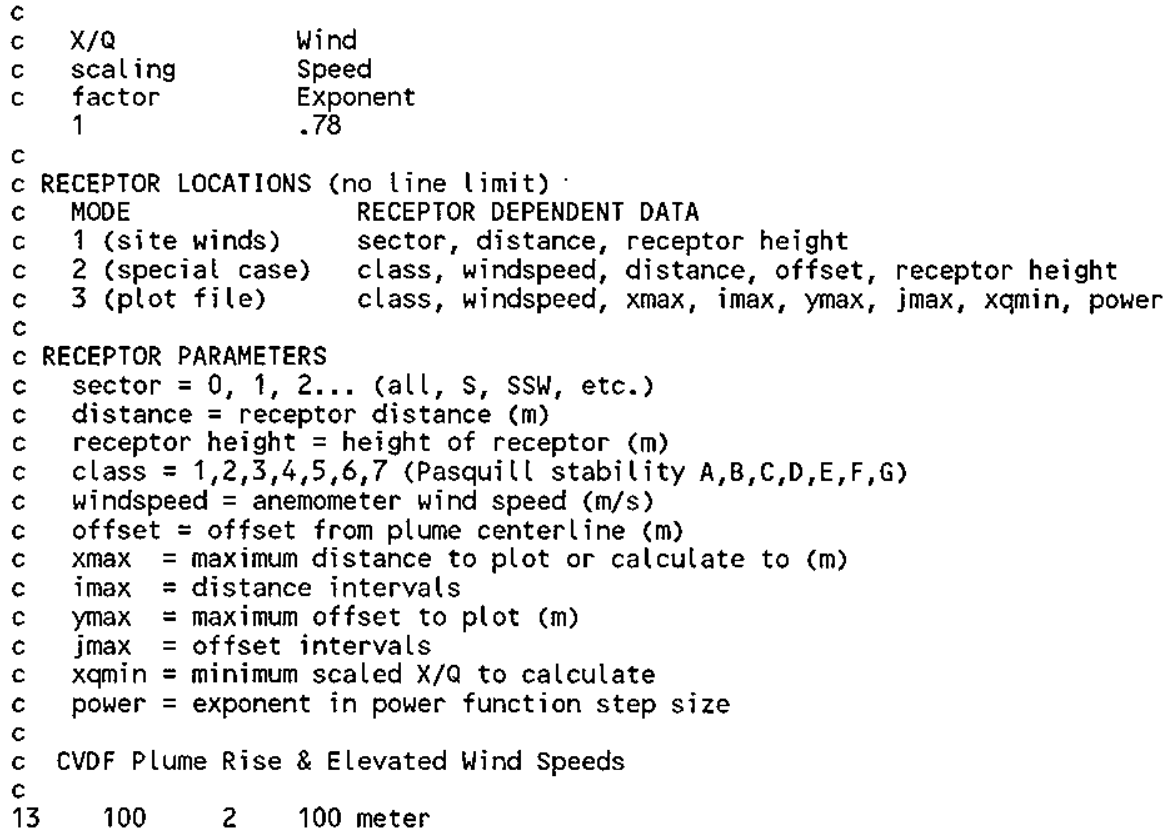

\section{Canister Storage Building, Natural Circulation Stack - Fumigation - Sector Maximum 99.5\%}

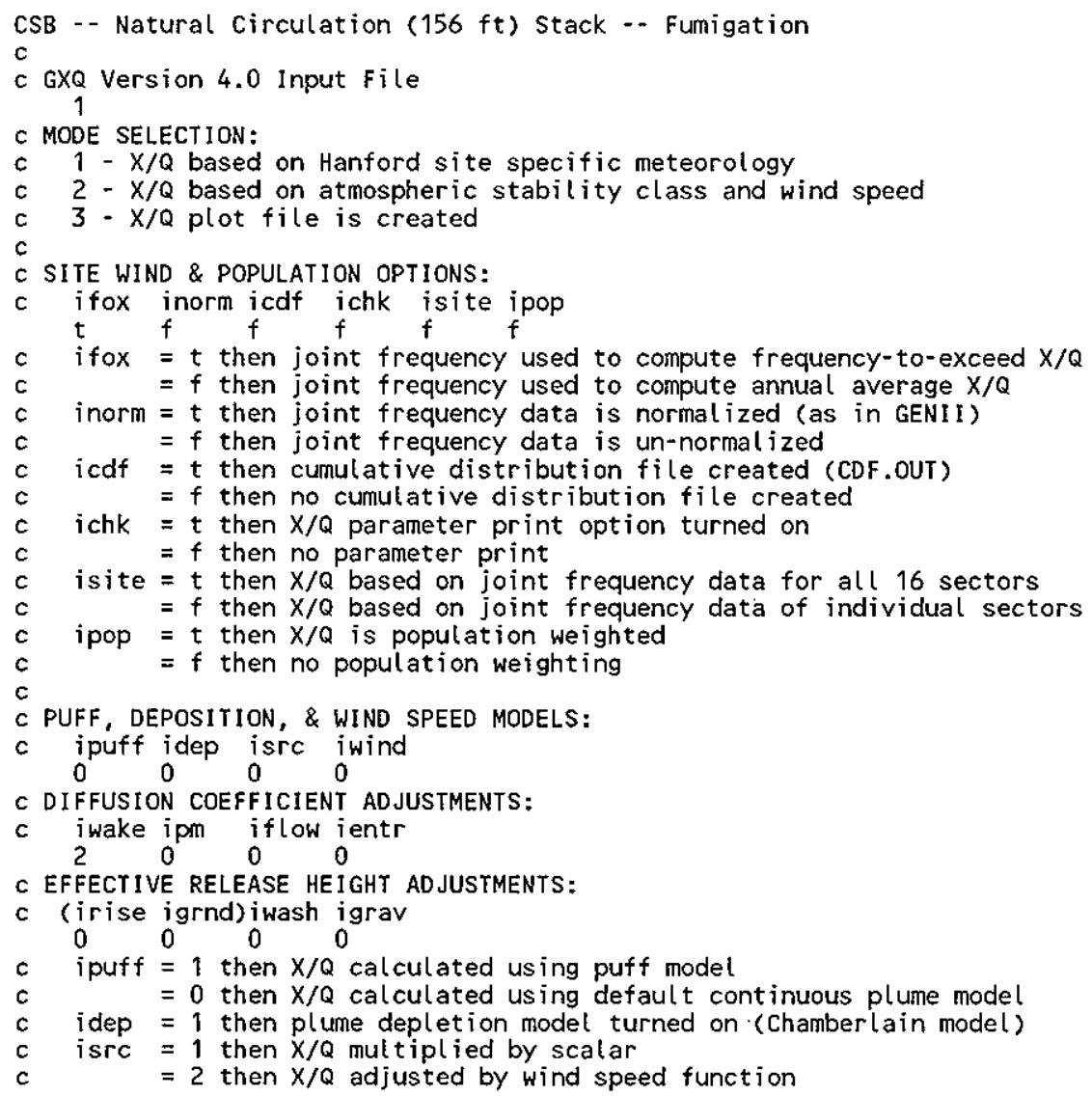




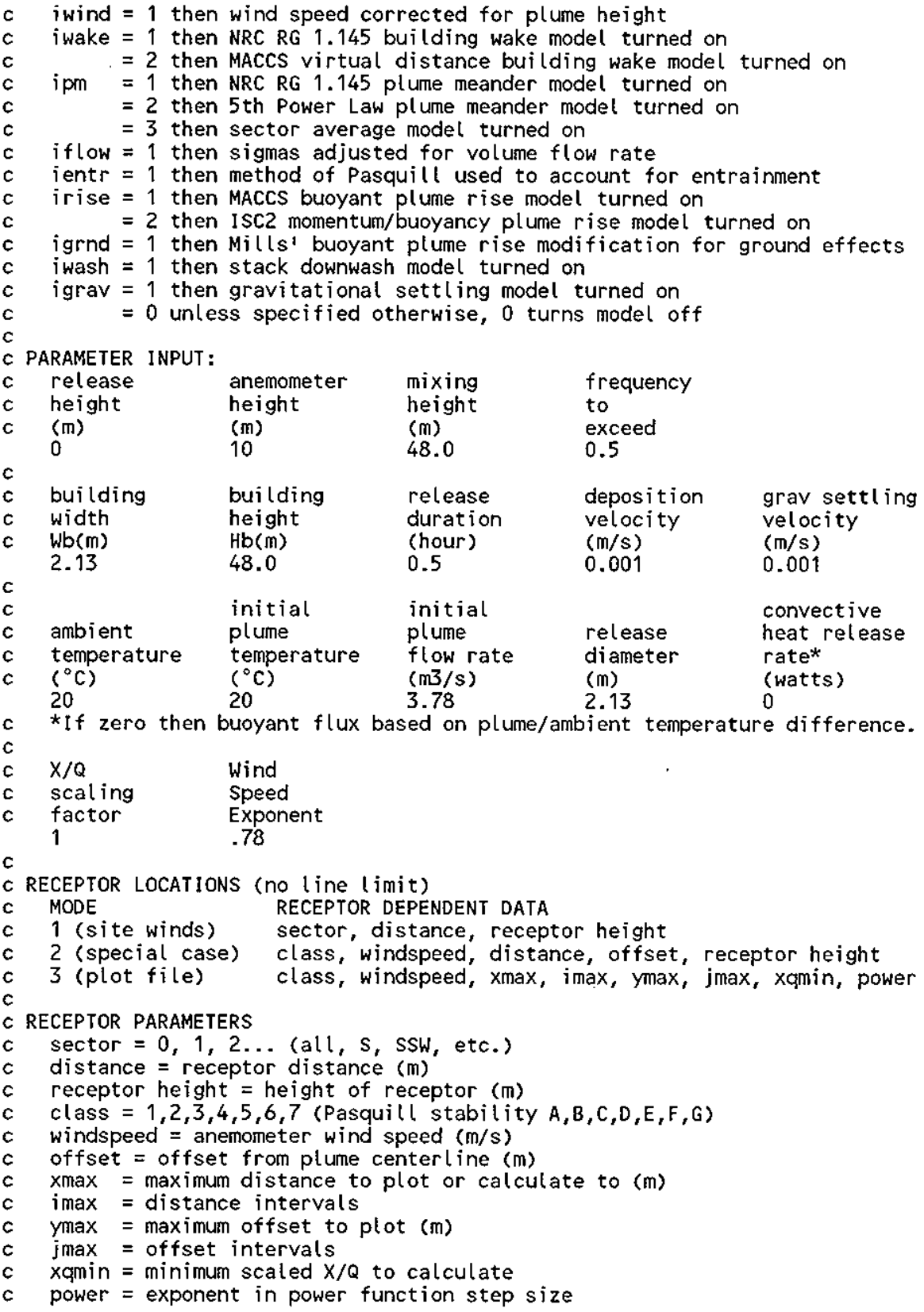

\section{Canister Storage Building, Natural Circulation} Stack - Less than 0.5 Hour - Sector Maximum 99.5\%

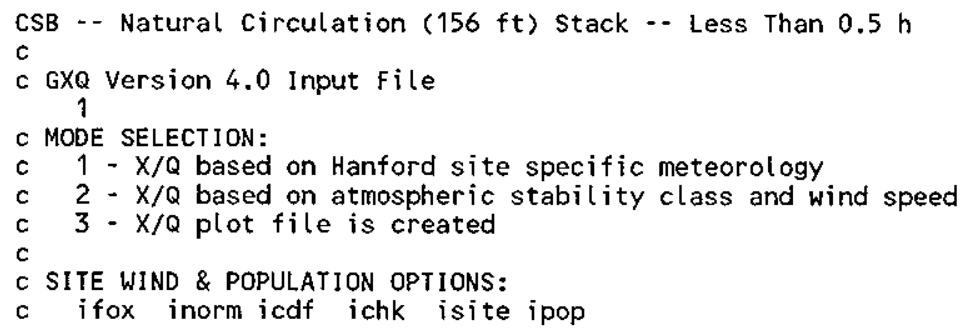




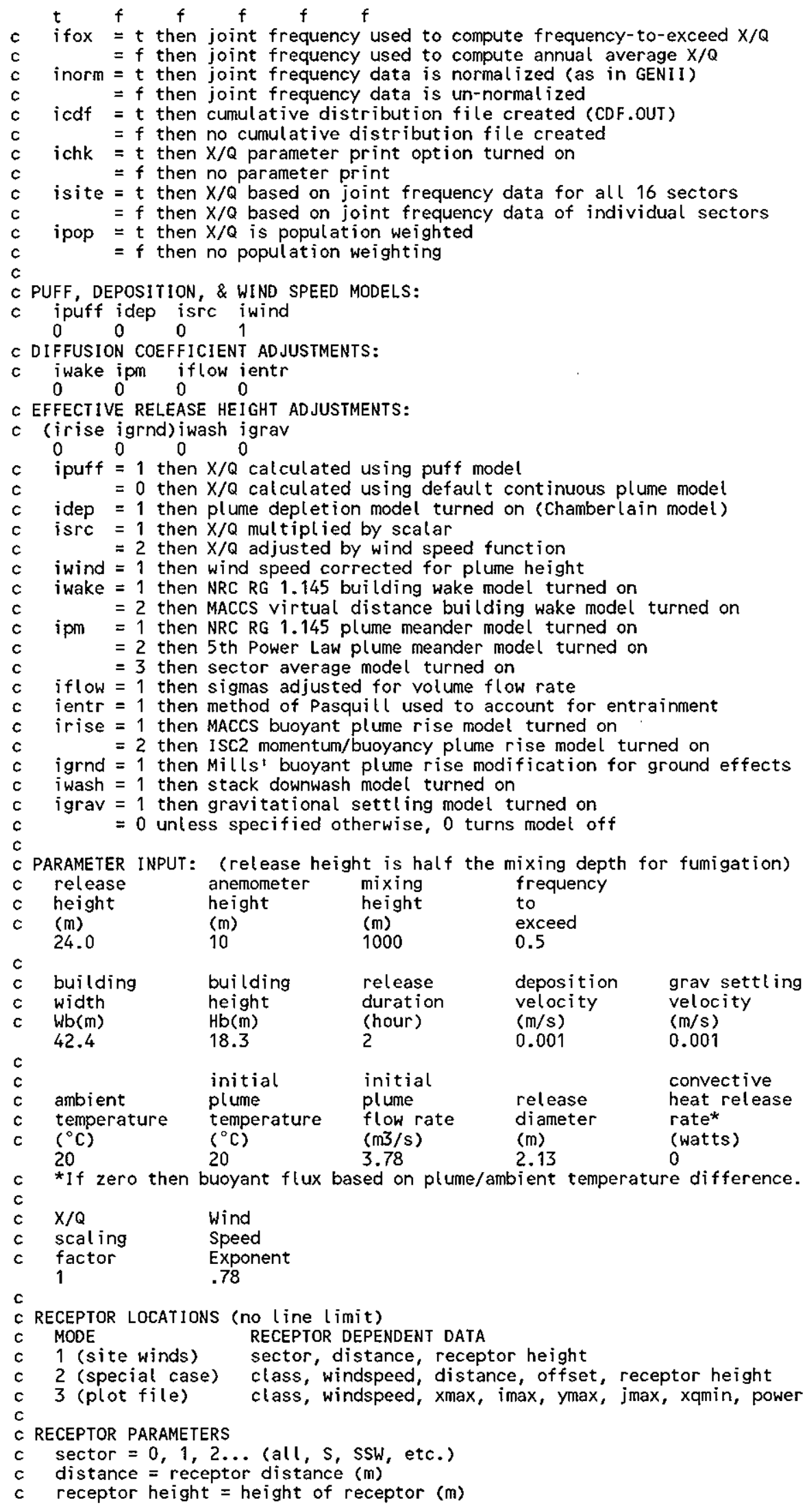






\section{Canister Storage Building, Natural Circulation Stack - 0.5 to 2 Hours - Sector Maximum $99.5 \%$}

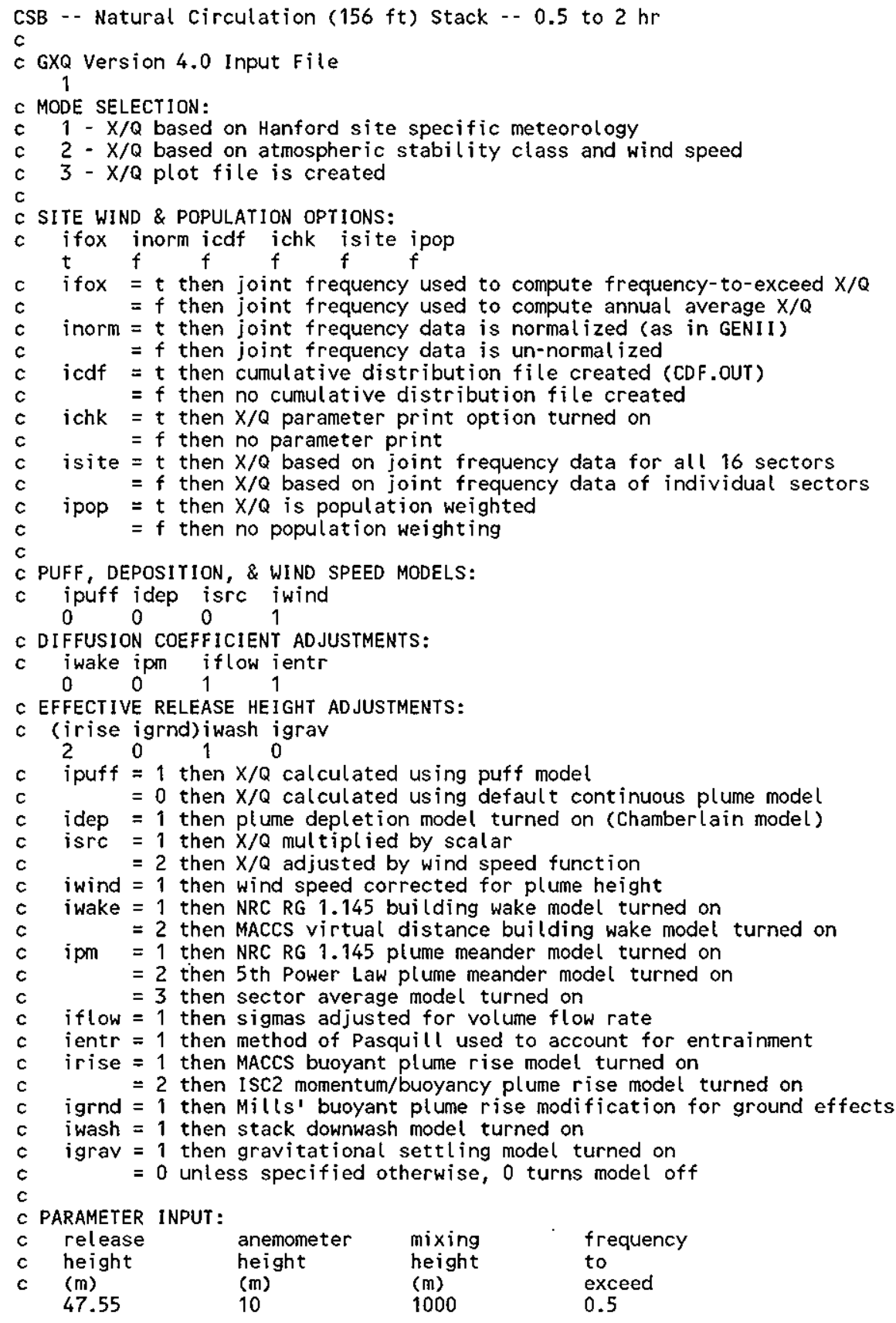




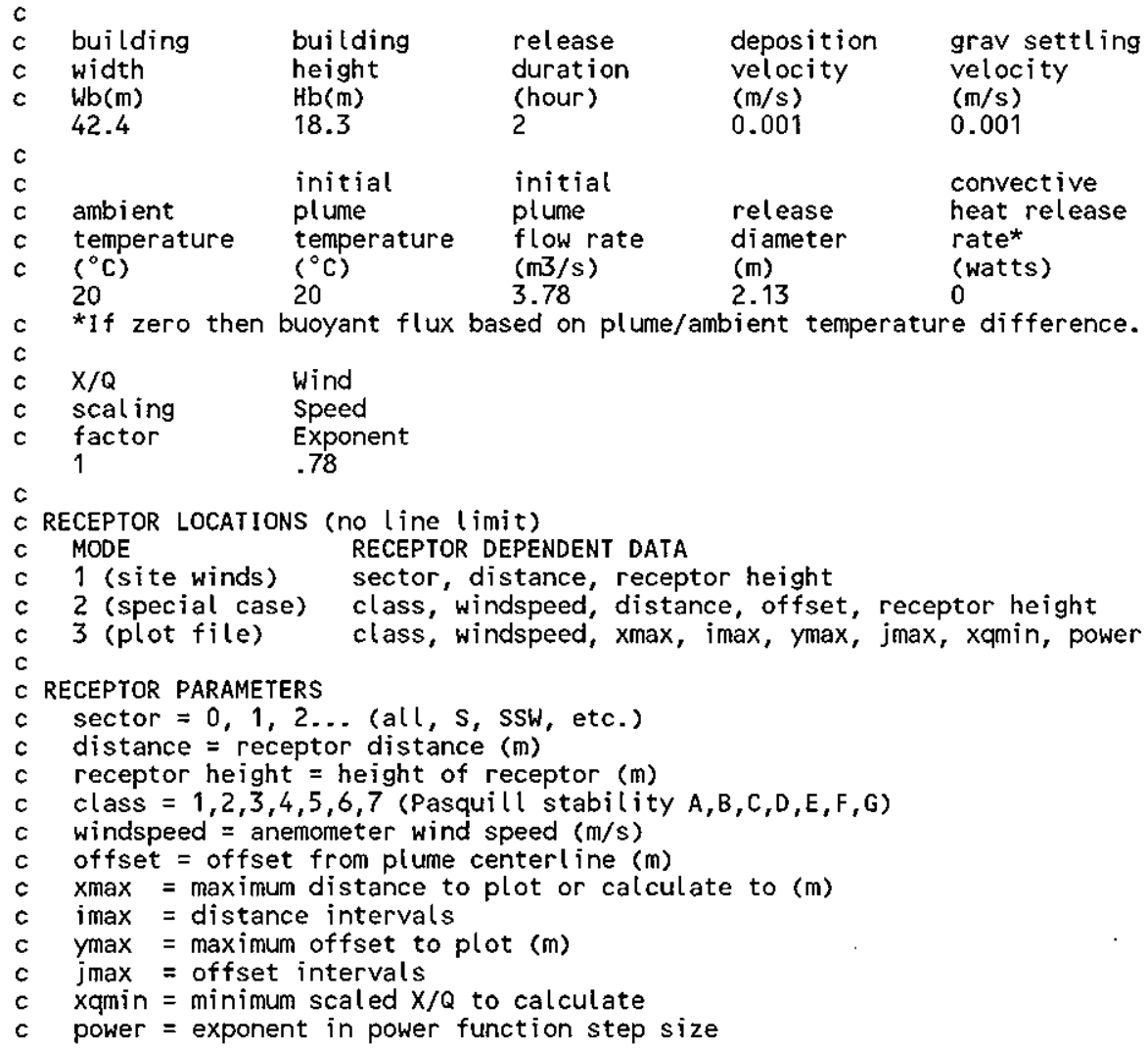

\section{Canister Storage Building, Natural Circulation Stack - Annual Average - Sector Maximum}

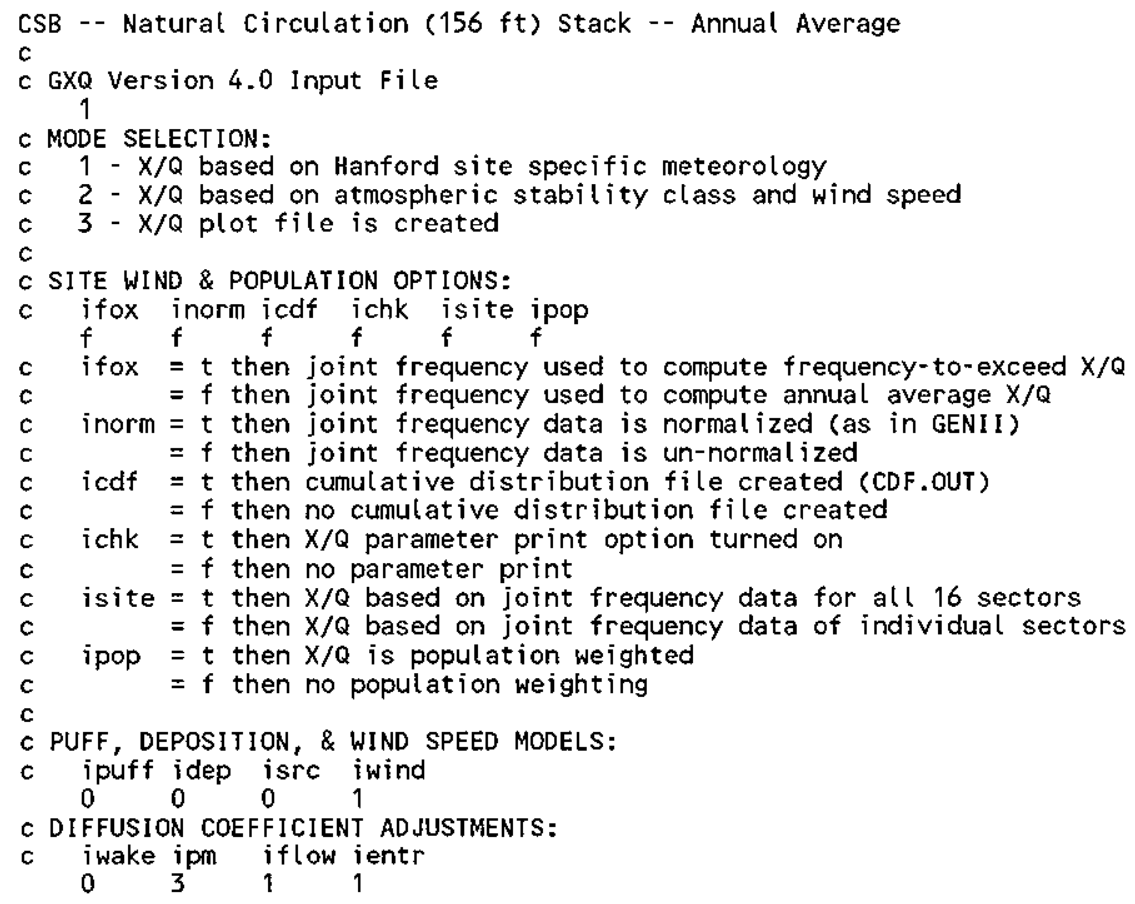




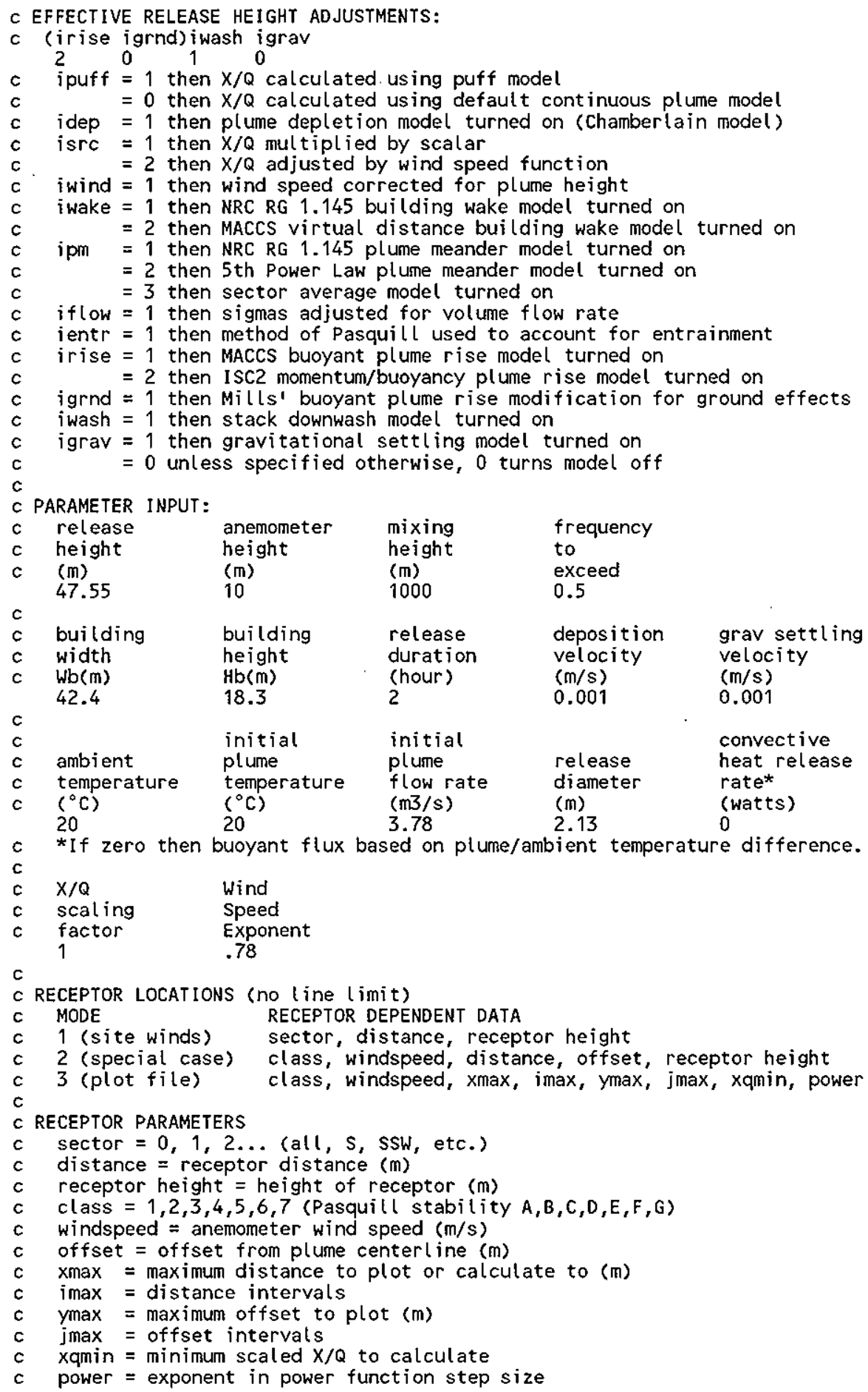

Note: The GXQ inputs for overall site X/Q are identical to the above except that the "isite" flag is " $\mathrm{t}$ " and the "frequency to exceed" is changed from 0.5 to 5.0 . 


\section{DOS Batch File to Combine Distances with Elevated Release Input Files and Run GXQ}

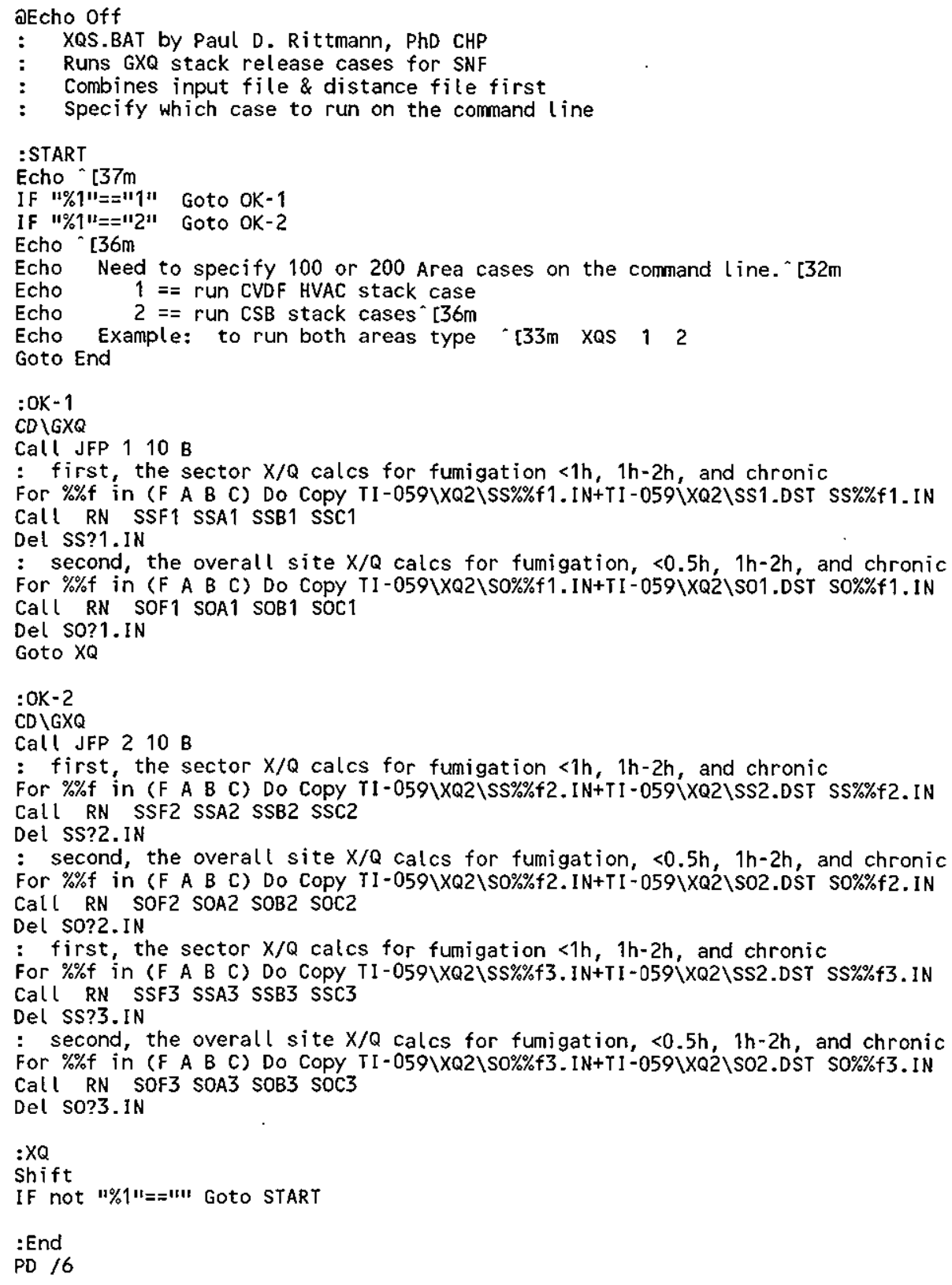


HNF-SD-SNF-TI-059 REV 2

APPENDIX E

JOINT FREQUENCY DATA AND WIND ROSES 
HNF-SD-SNF-TI-059 REV 2

This page intentionally left blank. 


\section{APPENDIX E}

\section{JOINT FREQUENCY DATA AND WIND ROSES}

The wind data files begin with two title lines. These show which tower the data was collected at, and who last modified the data in the file.

The third line has some information about the data layout. The first number in the line (8) is the number of wind speeds. The second number in the line is the number of stability classes ( $7-\mathrm{A}, \mathrm{B}, \mathrm{C}, \mathrm{D}, \mathrm{E}, \mathrm{F}, \mathrm{G})$. The next two numbers are not used. The last number $(10.0)$ gives the height in meters at which the wind speeds and other data apply.

The fourth line has the 8 wind speeds, in meters per second. These are the midpoints of the data actually collected. Since the data is collected using wind speed units of miles per hour (mph), the numbers are not exact. The table below shows the binning of the wind data. Note the coarseness of the low wind speed groupings. This contributes to the sharp differences between air transport factors for the various SNF facilities and release durations.

Binning of Wind Speeds for Joint Frequency Tables

\begin{tabular}{|c|c|}
\hline Midpoint Wind Speed & Range of Wind Speeds \\
\hline $0.89 \mathrm{~m} / \mathrm{s}$ & 1 to $3 \mathrm{mph}$ \\
\hline $2.65 \mathrm{~m} / \mathrm{s}$ & 4 to $8 \mathrm{mph}$ \\
\hline $4.70 \mathrm{~m} / \mathrm{s}$ & 9 to $12 \mathrm{mph}$ \\
\hline $7.15 \mathrm{~m} / \mathrm{s}$ & 13 to $19 \mathrm{mph}$ \\
\hline $9.80 \mathrm{~m} / \mathrm{s}$ & 20 to $24 \mathrm{mph}$ \\
\hline $12.7 \mathrm{~m} / \mathrm{s}$ & 25 to $32 \mathrm{mph}$ \\
\hline $15.6 \mathrm{~m} / \mathrm{s}$ & 33 to $37 \mathrm{mph}$ \\
\hline $19.0 \mathrm{~m} / \mathrm{s}$ & $38 \mathrm{mph}$ and higher \\
\hline
\end{tabular}

The remaining 56 lines ( 8 wind speeds times 7 stability classes) are the percentage of the hours in the period indicated in which the wind blows in a particular wind direction, in a given stability class and wind speed group. Each line contains 16 numbers corresponding to the 16 compass directions. The first column is wind direction (wind from) north. The second column is wind direction (wind from) north-northeast. The fifth column is wind direction (wind from) east, and so forth. The first line is the percents for class A at $0.89 \mathrm{~m} / \mathrm{s}$. The second line is class B at $0.89 \mathrm{~m} / \mathrm{s}$. The seventh line is class $G$ at $0.89 \mathrm{~m} / \mathrm{s}$. The eighth line is class $A$ at $2.65 \mathrm{~m} / \mathrm{s}$, and so forth.

No documentation for this data is available. It is derived from readings taken by the Hanford meteorology department at the Pacific Northwest National Laboratory. It is similar to published reports. 
100 N AREA - 10 M - Pasquill A - G (1983 - 1991 Average)

Created 8/26/92 KR

$\begin{array}{llllll}8 & 7 & 1 & 1 & 10.0\end{array}$

$\begin{array}{lllllllll}.89 & 2.65 & 4.7 & 7.15 & 9.8 & 12.7 & 15.6 & 19.0\end{array}$

$0.340 .140 .140 .13 \quad 0.270 .170 .13 \quad 0.110 .17 \quad 0.11 \quad 0.130 .190 .350 .320 .340 .30$

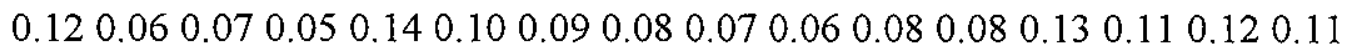
0.150 .070 .080 .100 .130 .110 .100 .070 .110 .070 .070 .100 .110 .110 .110 .10 $\begin{array}{lllllllllllllllllllll}0.71 & 0.42 & 0.38 & 0.45 & 1.03 & 0.89 & 0.70 & 0.53 & 0.75 & 0.51 & 0.59 & 0.57 & 0.90 & 0.64 & 0.62 & 0.57\end{array}$ $\begin{array}{lllllllllllllllllllll}0.60 & 0.37 & 0.42 & 0.48 & 0.98 & 0.68 & 0.54 & 0.44 & 0.56 & 0.42 & 0.51 & 0.61 & 0.86 & 0.67 & 0.54 & 0.52\end{array}$ $\begin{array}{llllllllllllllllll}0.57 & 0.32 & 0.41 & 0.46 & 0.88 & 0.51 & 0.42 & 0.25 & 0.35 & 0.29 & 0.40 & 0.63 & 0.92 & 0.67 & 0.58 & 0.52\end{array}$ $\begin{array}{llllllllllllllllll}0.25 & 0.17 & 0.18 & 0.22 & 0.36 & 0.18 & 0.15 & 0.11 & 0.15 & 0.13 & 0.22 & 0.35 & 0.63 & 0.41 & 0.32 & 0.28\end{array}$ $\begin{array}{llllllllllllllllll}0.60 & 0.42 & 0.32 & 0.14 & 0.32 & 0.28 & 0.25 & 0.17 & 0.16 & 0.14 & 0.33 & 0.45 & 0.73 & 0.48 & 0.40 & 0.43\end{array}$

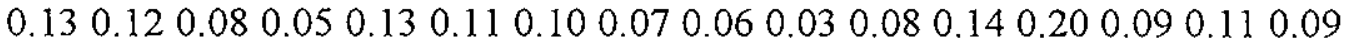
$\begin{array}{llllllllllllllllllllll}0.11 & 0.09 & 0.09 & 0.06 & 0.12 & 0.10 & 0.10 & 0.07 & 0.05 & 0.03 & 0.08 & 0.11 & 0.18 & 0.09 & 0.08 & 0.09\end{array}$ $\begin{array}{llllllllllllllll}0.60 & 0.47 & 0.37 & 0.37 & 0.72 & 0.71 & 0.65 & 0.39 & 0.39 & 0.32 & 0.52 & 1.05 & 1.33 & 0.68 & 0.50 & 0.41\end{array}$ $\begin{array}{lllllllllllllllllll}0.33 & 0.23 & 0.28 & 0.42 & 0.86 & 0.63 & 0.48 & 0.32 & 0.33 & 0.24 & 0.50 & 1.18 & 1.97 & 0.76 & 0.38 & 0.22\end{array}$

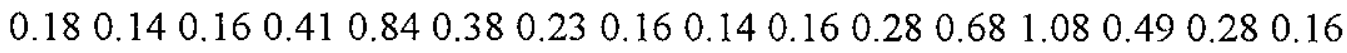
$\begin{array}{llllllllllllllll}0.05 & 0.05 & 0.08 & 0.19 & 0.32 & 0.13 & 0.09 & 0.05 & 0.05 & 0.06 & 0.13 & 0.29 & 0.59 & 0.18 & 0.09 & 0.04\end{array}$

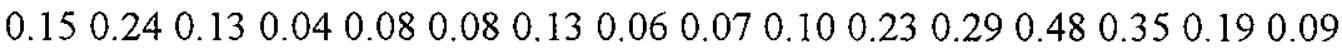

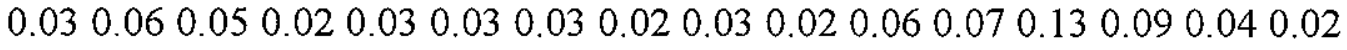
$\begin{array}{lllllllllllllllll}0.03 & 0.06 & 0.03 & 0.01 & 0.03 & 0.02 & 0.04 & 0.03 & 0.02 & 0.03 & 0.06 & 0.05 & 0.11 & 0.07 & 0.04 & 0.02\end{array}$ 0.190 .210 .170 .070 .090 .160 .260 .160 .120 .200 .330 .561 .170 .590 .190 .12

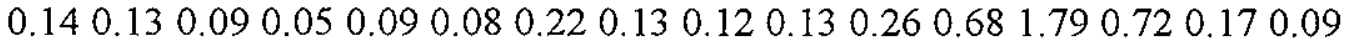
$\begin{array}{llllllllllllllll}0.08 & 0.07 & 0.03 & 0.05 & 0.06 & 0.04 & 0.07 & 0.04 & 0.02 & 0.02 & 0.06 & 0.25 & 0.33 & 0.13 & 0.04 & 0.05\end{array}$

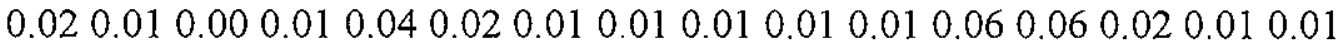
$\begin{array}{llllllllllllllllll}0.05 & 0.09 & 0.07 & 0.02 & 0.01 & 0.01 & 0.03 & 0.02 & 0.02 & 0.05 & 0.14 & 0.12 & 0.28 & 0.34 & 0.17 & 0.03\end{array}$

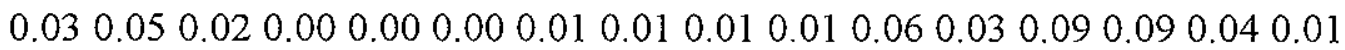
$\begin{array}{llllllllllllllllll}0.01 & 0.02 & 0.02 & 0.00 & 0.00 & 0.00 & 0.01 & 0.01 & 0.01 & 0.01 & 0.05 & 0.03 & 0.06 & 0.07 & 0.03 & 0.01\end{array}$ $\begin{array}{llllllllllllllll}0.09 & 0.13 & 0.05 & 0.02 & 0.01 & 0.02 & 0.05 & 0.05 & 0.05 & 0.10 & 0.28 & 0.19 & 0.56 & 0.61 & 0.20 & 0.05\end{array}$ $\begin{array}{llllllllllllllllll}0.10 & 0.10 & 0.04 & 0.02 & 0.00 & 0.01 & 0.03 & 0.03 & 0.03 & 0.07 & 0.11 & 0.15 & 0.65 & 0.56 & 0.13 & 0.04\end{array}$

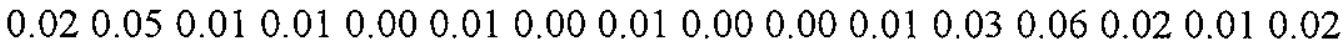
0.000 .000 .000 .000 .000 .000 .000 .000 .000 .000 .000 .010 .010 .000 .000 .00

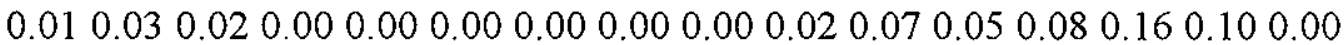

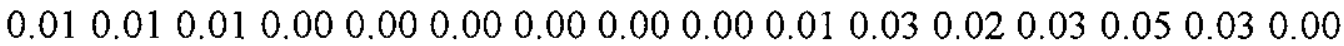

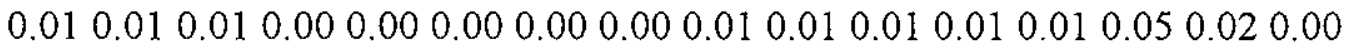

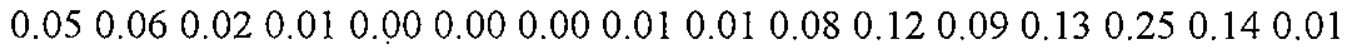

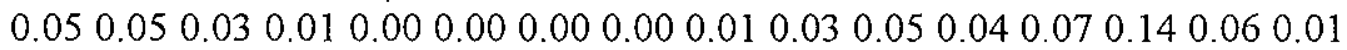

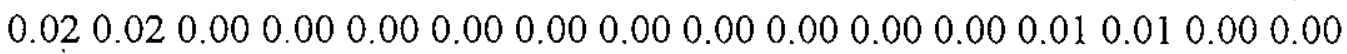
0.000 .000 .000 .000 .000 .000 .000 .000 .000 .000 .000 .000 .000 .000 .000 .00 0.000 .000 .000 .000 .000 .000 .000 .000 .000 .000 .020 .010 .010 .050 .040 .00 0.000 .010 .000 .000 .000 .000 .000 .000 .000 .000 .010 .000 .000 .010 .010 .00 $0.000 .000 .000 .00 \quad 0.000 .000 .000 .000 .000 .000 .010 .000 .000 .000 .000 .00$ $0.010 .040 .010 .010 .000 .000 .000 .000 .010 .040 .040 .02 \quad 0.040 .060 .020 .01$

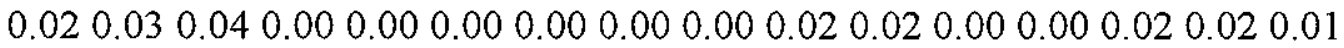

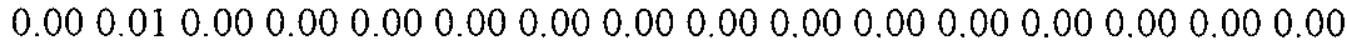
$0.00 \quad 0.00 \quad 0.000 .00 \quad 0.000 .00 \quad 0.000 .000 .00 \quad 0.00 \quad 0.00 \quad 0.00 \quad 0.000 .00 \quad 0.000 .00$

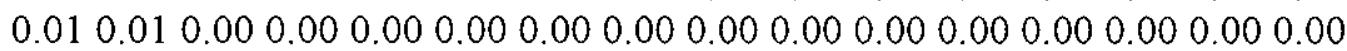
0.000 .000 .000 .000 .000 .000 .000 .000 .000 .000 .000 .000 .000 .000 .000 .00

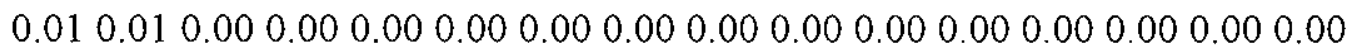




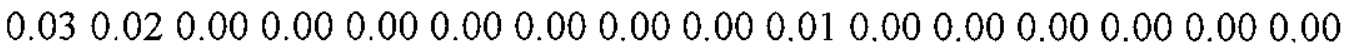

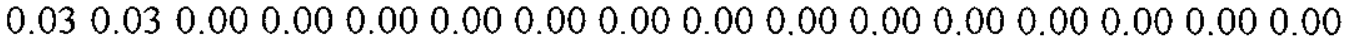



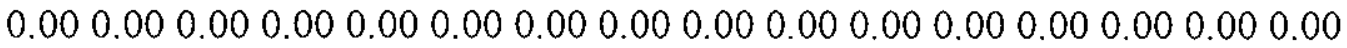

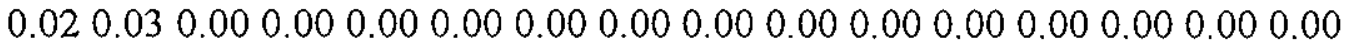

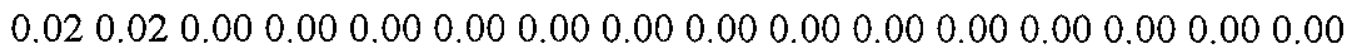
$0.020 .03 \quad 0.000 .000 .000 .000 .000 .000 .000 .000 .000 .000 .000 .000 .000 .00$


0.070 .140 .000 .000 .000 .000 .000 .000 .000 .000 .000 .000 .000 .000 .000 .00 0.030 .060 .000 .000 .000 .000 .000 .000 .000 .000 .000 .000 .000 .000 .000 .00

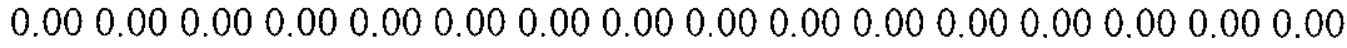


200 AREA (HMS) - 10 M - Pasquill A - G (1983 - 1991 Average)

Created 8/26/92 KR

$\begin{array}{llllll}8 & 7 & 1 & 1 & 10.0\end{array}$

$\begin{array}{llllllll}.89 & 2.65 & 4.7 & 7.15 & 9.8 & 12.7 & 15.6 & 19.0\end{array}$

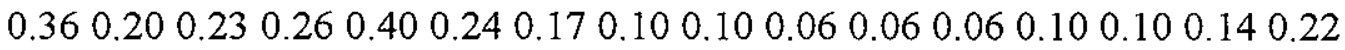



0.140 .100 .090 .120 .140 .100 .060 .040 .040 .020 .020 .020 .040 .040 .100 .10

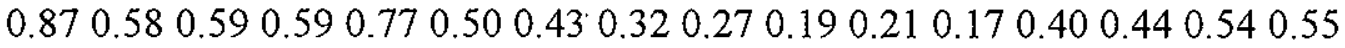

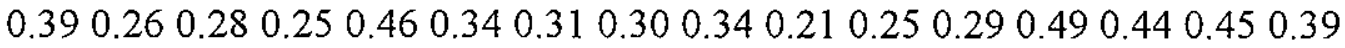

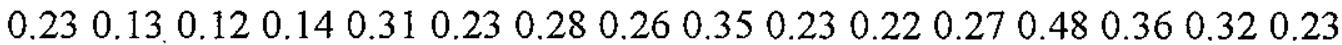

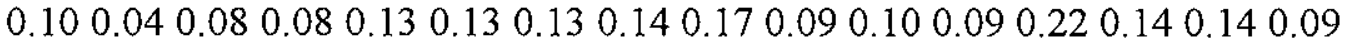

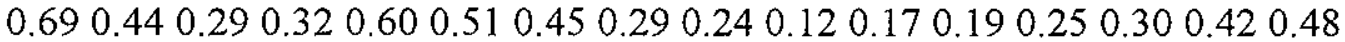

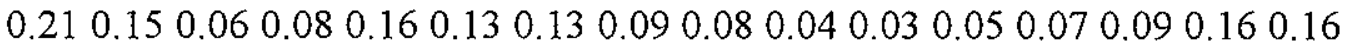

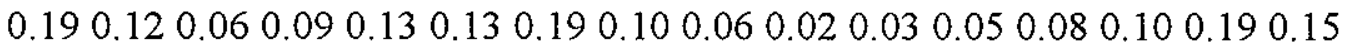

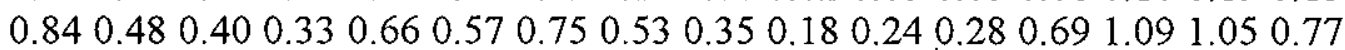

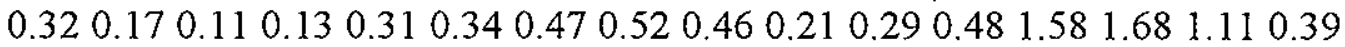

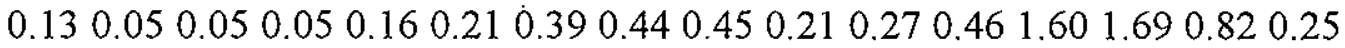

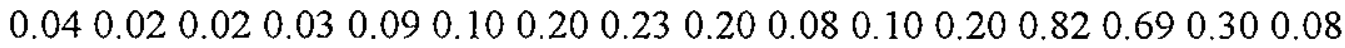

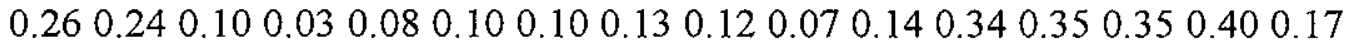

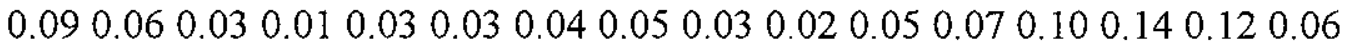
$\begin{array}{llllllllllllllllll}0.08 & 0.05 & 0.03 & 0.01 & 0.02 & 0.02 & 0.04 & 0.04 & 0.05 & 0.02 & 0.03 & 0.06 & 0.09 & 0.13 & 0.12 & 0.03\end{array}$

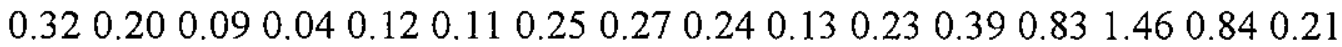

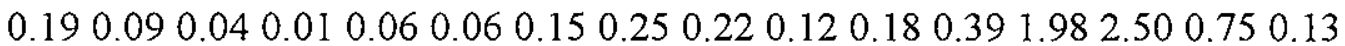

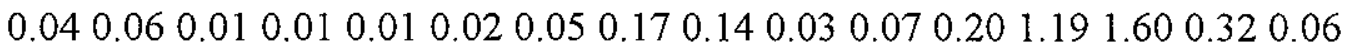

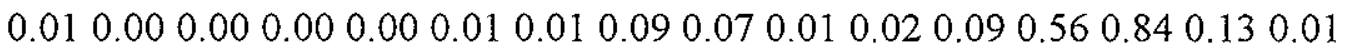

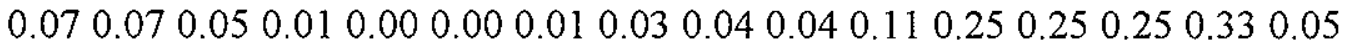

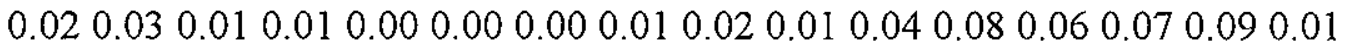

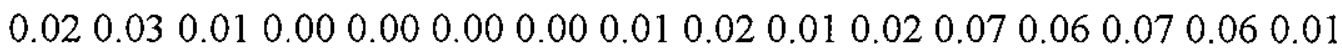

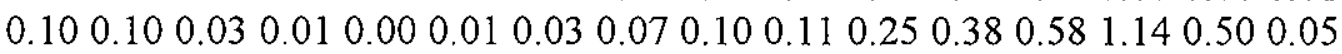

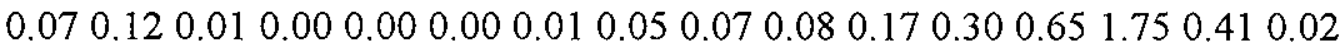

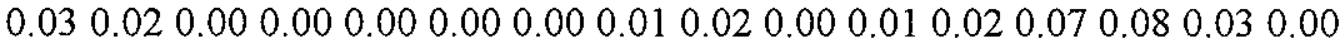

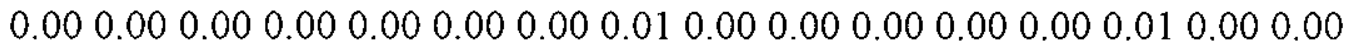

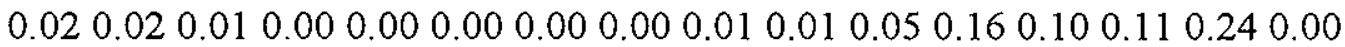
$\begin{array}{lllllllllllllllll}0.01 & 0.010 .00 & 0.00 & 0.00 & 0.00 & 0.00 & 0.00 & 0.00 & 0.00 & 0.02 & 0.04 & 0.02 & 0.03 & 0.06 & 0.00\end{array}$

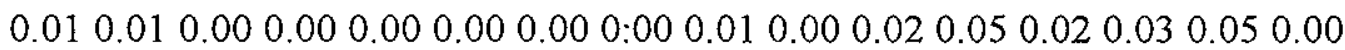

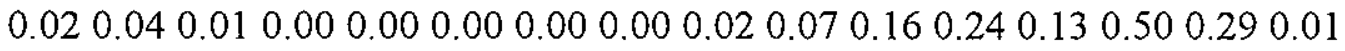

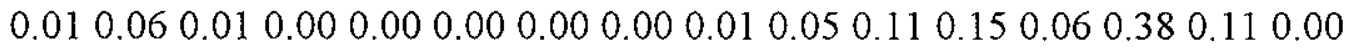

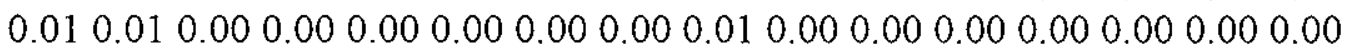

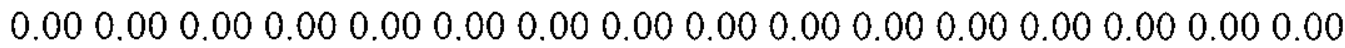





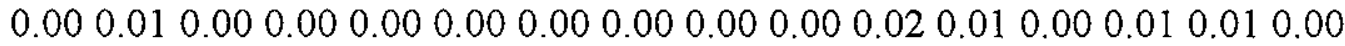

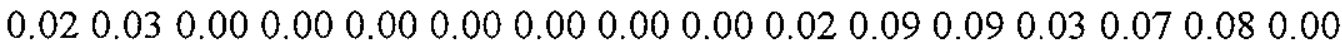

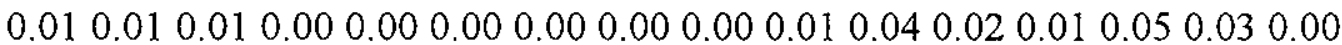

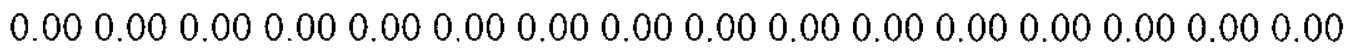

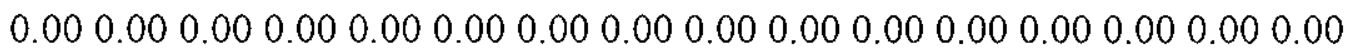

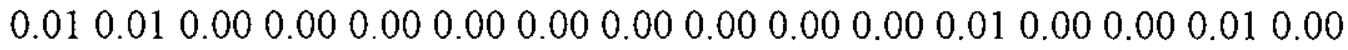
0.000 .010 .000 .000 .000 .000 .000 .000 .000 .000 .000 .000 .000 .000 .000 .00

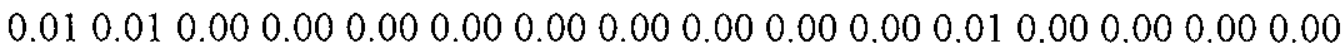




\section{HNF-SD-SNF-TI-059 REV 2}

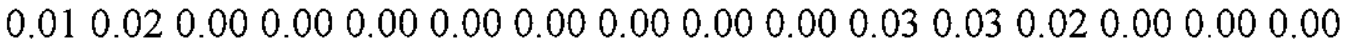

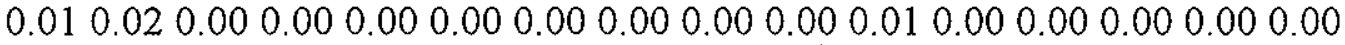

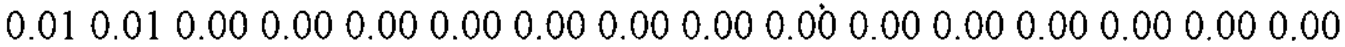

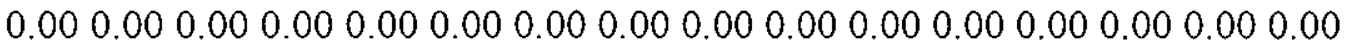

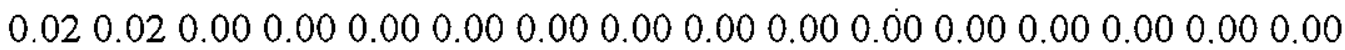

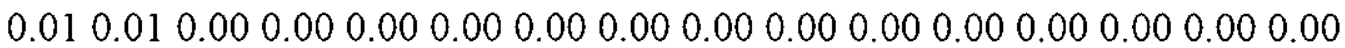



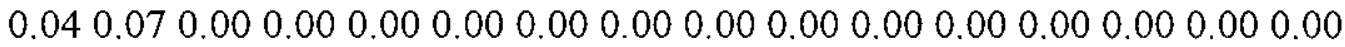
0.070 .120 .000 .000 .000 .000 .000 .000 .000 .000 .000 .000 .000 .000 .000 .00

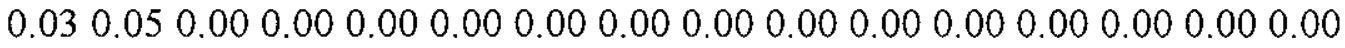

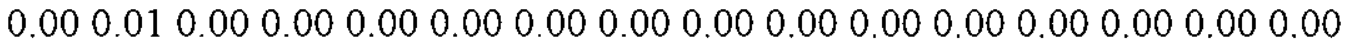


Figure E-1. 100-N Area Wind Rose.

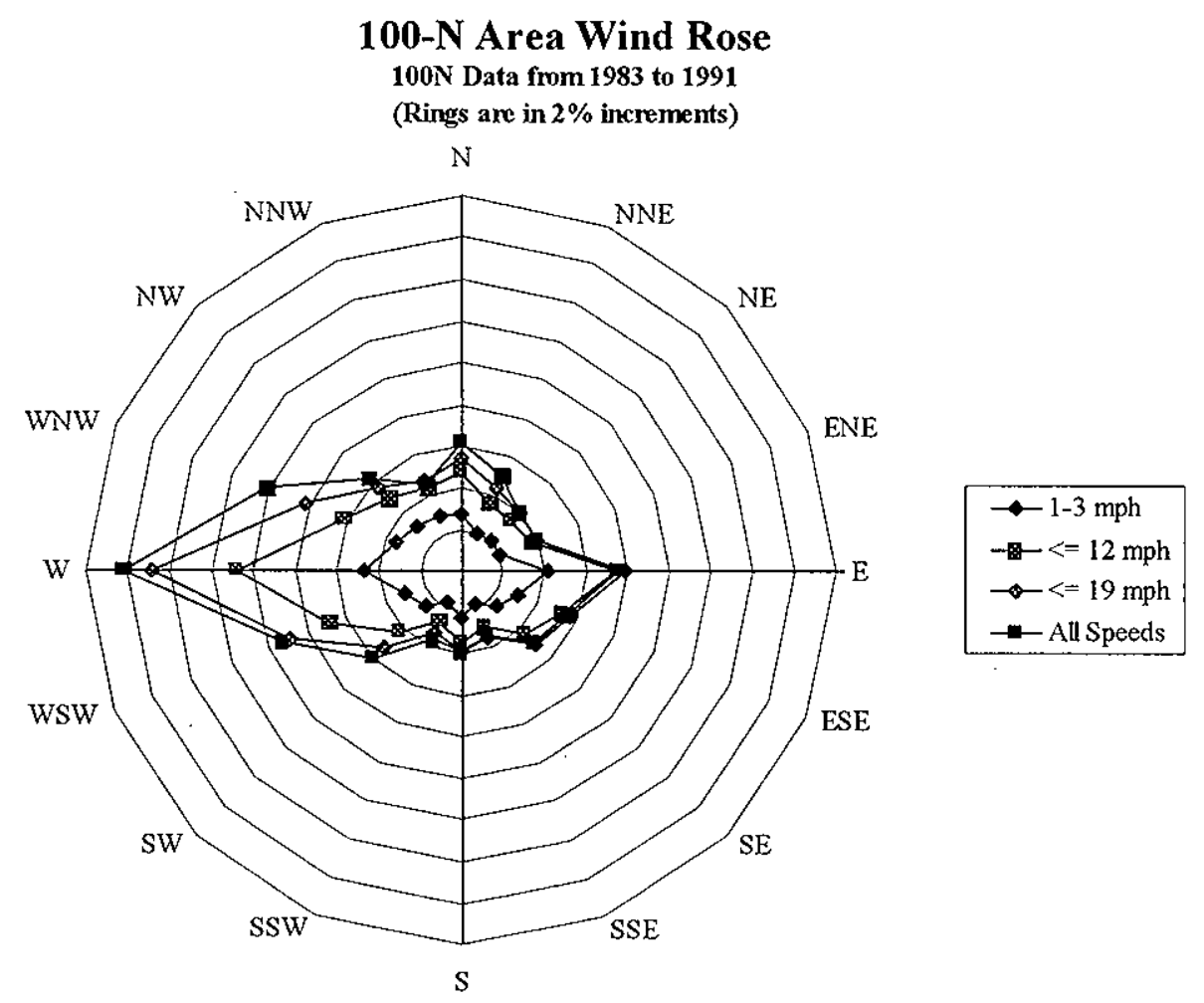

Compass points are standard "wind from" wind directions. 
Figure E-2. 200 Area Wind Rose.

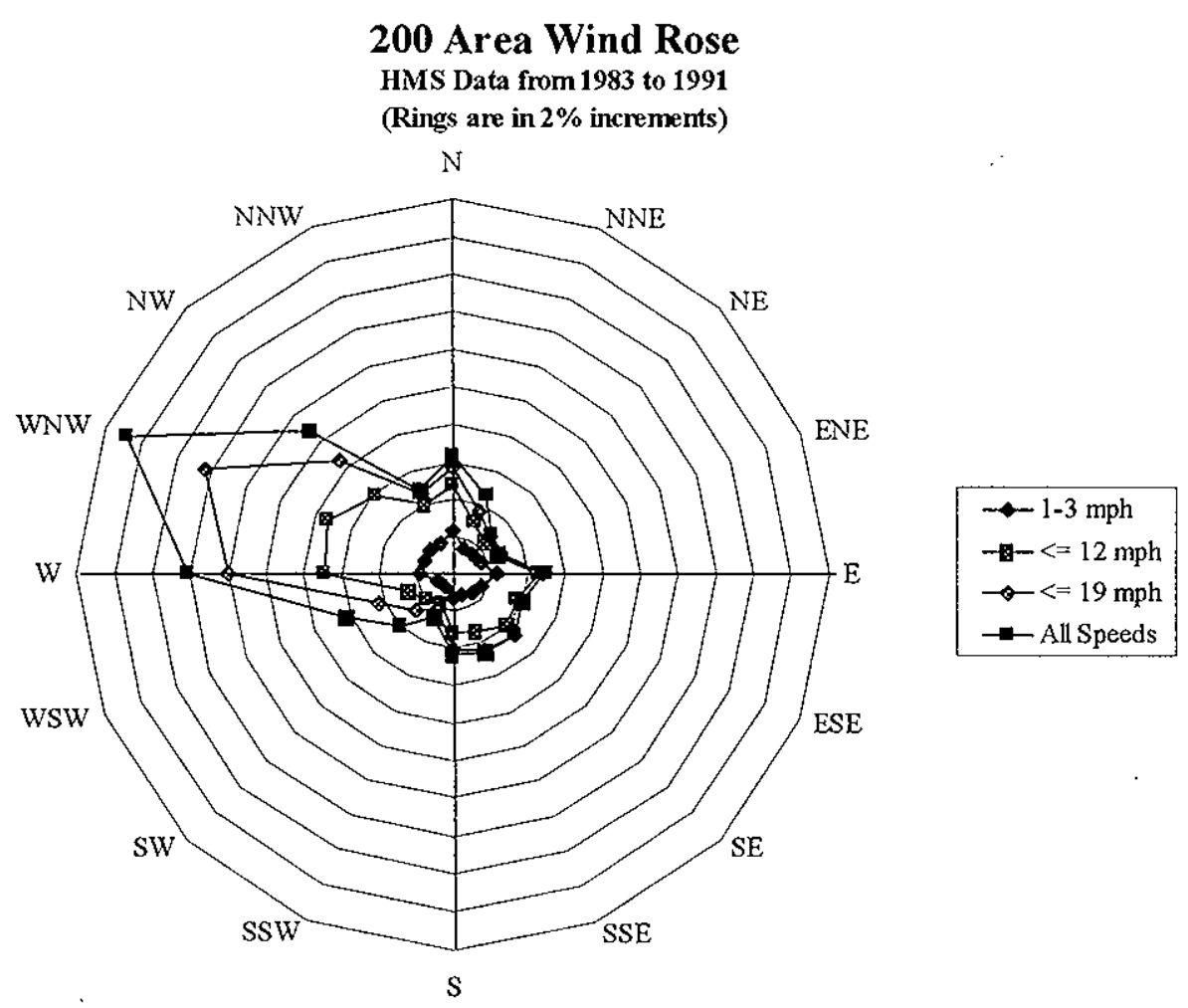

Compass points are standard "wind from" wind directions. 
HNF-SD-SNF-TI-059 REV 2

This page intentionally left blank. 
HNF-SD-SNF-TI-059 REV 2

APPENDIX F

UNIT DOSE WITH INSOLUBLE LUNG CLASSES 
HNF-SD-SNF-TI-059 REV 2

This page intentionally left blank. 
Table F-1. Unit Dose Factor with Insoluble Lung Clearances. (3 sheets)

\begin{tabular}{|c|c|c|c|c|c|c|}
\hline \multirow{2}{*}{ Nuclide } & \multirow{2}{*}{$\begin{array}{l}\text { Activity }^{\mathrm{a}} \\
\text { (Ci/MTU) }\end{array}$} & \multirow{2}{*}{$\begin{array}{l}\text { Activity } \\
(\mathrm{Bq} / \mathrm{gU})\end{array}$} & \multicolumn{2}{|c|}{ Inhalation $\mathrm{DF}^{\mathrm{b}}$} & \multirow{2}{*}{$\begin{array}{c}\mathrm{UD}^{\mathrm{c}} \\
(\mathrm{Sv} / \mathrm{gU})\end{array}$} & \multirow{2}{*}{$\begin{array}{c}\text { Percent of } \\
\text { Total }\end{array}$} \\
\hline & & & $(\mathrm{Sv} / \mathrm{Bq})$ & Class & & \\
\hline \multicolumn{7}{|c|}{ Fission and Activation Products } \\
\hline $\mathrm{H}-3$ & $2.61 E+01$ & $9.66 \mathrm{E}+05$ & $2.60 \mathrm{E}-11$ & Vapor & $2.51 \mathrm{E}-05$ & $0.00 \%$ \\
\hline $\mathrm{C}-14$ & $5.53 \mathrm{E}-01$ & $2.05 \mathrm{E}+04$ & $5.64 \mathrm{E}-10$ & Organic & $1.15 \mathrm{E}-05$ & $0.00 \%$ \\
\hline $\mathrm{Fe}-55$ & $5.41 \mathrm{E}-01$ & $2.00 \mathrm{E}+04$ & $3.61 \mathrm{E}-10$ & W & $7.23 \mathrm{E}-06$ & $0.00 \%$ \\
\hline $\mathrm{Co}-60$ & $2.09 \mathrm{E}+00$ & $7.73 \mathrm{E}+04$ & $5.91 \mathrm{E}-08$ & $\mathrm{Y}$ & $4.57 \mathrm{E}-03$ & $0.00 \%$ \\
\hline $\mathrm{Ni}-59$ & $3.18 \mathrm{E}-02$ & $1.18 \mathrm{E}+03$ & $2.48 \mathrm{E}-10$ & $\mathrm{~W}$ & $2.92 \mathrm{E}-07$ & $0.00 \%$ \\
\hline $\mathrm{Ni}-63$ & $3.47 \mathrm{E}+00$ & $1.28 \mathrm{E}+05$ & $6.22 \mathrm{E}-10$ & $\mathrm{~W}$ & 7.99 E-05 & $0.00 \%$ \\
\hline Se-79 & $6.54 \mathrm{E}-02$ & $2.42 \mathrm{E}+03$ & $2.66 \mathrm{E}-09$ & W & $6.44 \mathrm{E}-06$ & $0.00 \%$ \\
\hline $\mathrm{Kr}-85$ & $3.70 \mathrm{E}+02$ & $1.37 \mathrm{E}+07$ & $3.57 \mathrm{E}-13$ & $\mathrm{Gas}^{\mathrm{d}}$ & $4.89 \mathrm{E}-06$ & $0.00 \%$ \\
\hline $\mathrm{Sr}-90$ & $6.93 \mathrm{E}+03$ & $2.56 \mathrm{E}+08$ & $6.47 \mathrm{E}-08$ & $\mathrm{D}$ & $1.66 \mathrm{E}+01$ & $0.46 \%$ \\
\hline$Y-90$ & $6.93 \mathrm{E}+03$ & $2.56 \mathrm{E}+08$ & $2.28 \mathrm{E}-09$ & $\mathrm{Y}$ & $5.85 \mathrm{E}-01$ & $0.02 \%$ \\
\hline $\mathrm{Zr}-93$ & $2.95 \mathrm{E}-01$ & $1.09 \mathrm{E}+04$ & $2.00 \mathrm{E}-08$ & Y & $2.18 \mathrm{E}-04$ & $0.00 \%$ \\
\hline $\mathrm{Nb}-93 \mathrm{~m}$ & $1.93 \mathrm{E}-01$ & $7.14 \mathrm{E}+03$ & 7.90 E-09 & $\mathrm{Y}$ & $5.64 \mathrm{E}-05$ & $0.00 \%$ \\
\hline Tc-99 & $2.19 \mathrm{E}+00$ & $8.10 \mathrm{E}+04$ & $2.25 \mathrm{E}-09$ & W & $1.82 \mathrm{E}-04$ & $0.00 \%$ \\
\hline Ru-106 & $2.56 \mathrm{E}-02$ & $9.47 \mathrm{E}+02$ & $1.29 \mathrm{E}-07$ & $Y$ & $1.22 \mathrm{E}-04$ & $0.00 \%$ \\
\hline Rh-106 & $2.56 \mathrm{E}-02$ & $9.47 \mathrm{E}+02$ & $\mathrm{DP}^{e}$ & NA & NA & NA \\
\hline Pd-107 & $1.56 \mathrm{E}-02$ & $5.77 \mathrm{E}+02$ & 3.45 E-09 & $\mathrm{Y}$ & $1.99 \mathrm{E}-06$ & $0.00 \%$ \\
\hline Ag-110 & $7.17 \mathrm{E}-10$ & $2.65 \mathrm{E}-05$ & $\mathrm{DP}^{\mathrm{c}}$ & NA & NA & NA \\
\hline $\mathrm{Ag}-110 \mathrm{~m}$ & $5.39 \mathrm{E}-08$ & $1.99 \mathrm{E}-03$ & 2.17 E-08 & Y & $4.33 \mathrm{E}-11$ & $0.00 \%$ \\
\hline $\mathrm{Cd}-113 \mathrm{~m}$ & $2.78 E+00$ & $1.03 \mathrm{E}+05$ & $1.08 \mathrm{E}-07$ & $\mathrm{Y}$ & $1.11 \mathrm{E}-02$ & $0.00 \%$ \\
\hline In-113m & $1.36 \mathrm{E}-19$ & $5.03 \mathrm{E}-15$ & $9.04 \mathrm{E}-12$ & W & $4.55 \mathrm{E}-26$ & $0.00 \%$ \\
\hline Sn-113 & $1.36 \mathrm{E}-19$ & $5.03 \mathrm{E}-15$ & $2.88 \mathrm{E}-09$ & W & $1.45 \mathrm{E}-23$ & $0.00 \%$ \\
\hline Sn-119m & 6.14 E-08 & $2.27 \mathrm{E}-03$ & $1.69 \mathrm{E}-09$ & $W$ & $3.84 \mathrm{E}-12$ & $0.00 \%$ \\
\hline $\mathrm{Sn}-121 \mathrm{~m}$ & $6.27 \mathrm{E}-02$ & $2.32 \mathrm{E}+03$ & $3.11 \mathrm{E}-09$ & W & $7.21 \mathrm{E}-06$ & $0.00 \%$ \\
\hline Sn-123 & $1.72 \mathrm{E}-16$ & $6.36 \mathrm{E}-12$ & 8.79 E-09 & W & $5.59 \mathrm{E}-20$ & $0.00 \%$ \\
\hline Sn-126 & $1.29 \mathrm{E}-01$ & $4.77 \mathrm{E}+03$ & $2.69 \mathrm{E}-08$ & W & $1.28 \mathrm{E}-04$ & $0.00 \%$ \\
\hline
\end{tabular}


Table F-1. Unit Dose Factor with Insoluble Lung Clearances. (3 sheets)

\begin{tabular}{|c|c|c|c|c|c|c|}
\hline \multirow{2}{*}{ Nuclide } & \multirow{2}{*}{$\begin{array}{l}\text { Activity }^{\mathrm{a}} \\
\text { (Ci/MTU) }\end{array}$} & \multirow{2}{*}{$\begin{array}{l}\text { Activity } \\
(\mathrm{Bq} / \mathrm{gU})\end{array}$} & \multicolumn{2}{|c|}{ Inhalation $\mathrm{DF}^{\mathrm{b}}$} & \multirow{2}{*}{$\begin{array}{c}\mathrm{UD}^{\mathrm{c}} \\
(\mathrm{Sv} / \mathrm{gU})\end{array}$} & \multirow{2}{*}{$\begin{array}{c}\text { Percent or } \\
\text { Total }\end{array}$} \\
\hline & & & $(\mathrm{Sv} / \mathrm{Bq})$ & Class & & \\
\hline $\mathrm{Sb}-125$ & 0.00 & 0.00 & 3.30 E-09 & W & 0.00 & $0.00 \%$ \\
\hline Sb-126 & $1.81 \mathrm{E}-02$ & $6.70 \mathrm{E}+02$ & $3.17 \mathrm{E}-09$ & W & $2.12 \mathrm{E}-06$ & $0.00 \%$ \\
\hline $\mathrm{Sb}-126 \mathrm{~m}$ & $1.29 \mathrm{E}-01$ & $4.77 \mathrm{E}+03$ & $7.72 \mathrm{E}-12$ & $W$ & $3.68 \mathrm{E}-08$ & $0.00 \%$ \\
\hline $\mathrm{Te}-123 \mathrm{~m}$ & $1.50 \mathrm{E}-21$ & $5.55 \mathrm{E}-17$ & $2.86 \mathrm{E}-09$ & W & $1.59 \mathrm{E}-25$ & $0.00 \%$ \\
\hline $\mathrm{Te}-125 \mathrm{~m}$ & 0.00 & 0.00 & 1.97 E-09 & W & 0.00 & $0.00 \%$ \\
\hline Te-127 & $2.12 \mathrm{E}-19$ & 7.84 E-15 & $8.60 \mathrm{E}-11$ & W & $6.75 \mathrm{E}-25$ & $0.00 \%$ \\
\hline $\mathrm{Te}-127 \mathrm{~m}$ & $2.16 \mathrm{E}-19$ & 7.99 E-15 & $5.81 \mathrm{E}-09$ & $W$ & $4.64 \mathrm{E}-23$ & $0.00 \%$ \\
\hline I-129 & $5.16 \mathrm{E}-03$ & $1.91 \mathrm{E}+02$ & $4.69 \mathrm{E}-08$ & D & $8.95 \mathrm{E}-06$ & $0.00 \%$ \\
\hline Cs- 134 & $6.47 \mathrm{E}+00$ & $2.39 \mathrm{E}+05$ & $1.25 \mathrm{E}-08$ & $\mathrm{D}$ & $2.99 \mathrm{E}-03$ & $0.00 \%$ \\
\hline Cs- 135 & $6.04 \mathrm{E}-02$ & $2.23 \mathrm{E}+03$ & $1.23 \mathrm{E}-09$ & $\mathrm{D}$ & $2.75 \mathrm{E}-06$ & $0.00 \%$ \\
\hline Cs- 137 & $9.66 \mathrm{E}+03$ & $3.57 \mathrm{E}+08$ & 8.63 E-09 & $\mathrm{D}$ & $3.08 \mathrm{E}+00$ & $0.08 \%$ \\
\hline $\mathrm{Ba}-137 \mathrm{~m}$ & $9.14 \mathrm{E}+03$ & $3.38 \mathrm{E}+08$ & $\mathrm{DP}^{\mathrm{c}}$ & NA & NA & NA \\
\hline Ce-144 & 7.91 E-04 & $2.93 \mathrm{E}+01$ & $1.01 \mathrm{E}-07$ & Y & $2.96 \mathrm{E}-06$ & $0.00 \%$ \\
\hline Pr-144 & $7.82 \mathrm{E}-04$ & $2.89 \mathrm{E}+01$ & $1.17 \mathrm{E}-11$ & $Y$ & $3.39 \mathrm{E}-10$ & $0.00 \%$ \\
\hline $\operatorname{Pr}-144 \mathrm{~m}$ & 9.48 E-06 & $3.51 \mathrm{E}-01$ & $\mathrm{DP}^{\mathrm{c}}$ & NA & NA & $\mathrm{NA}$ \\
\hline Pm-147 & $1.09 \mathrm{E}+02$ & $4.03 \mathrm{E}+06$ & $1.06 \mathrm{E}-08$ & $\mathrm{Y}$ & $4.27 \mathrm{E}-02$ & $0.00 \%$ \\
\hline Sm-151 & $1.02 \mathrm{E}+02$ & $3.77 \mathrm{E}+06$ & 8.10 E-09 & W & 3.06 E-02 & $0.00 \%$ \\
\hline $\mathrm{Eu}-152$ & 8.45 E-01 & $3.13 \mathrm{E}+04$ & 5.97 E-08 & $\mathrm{W}$ & $1.87 \mathrm{E}-03$ & $0.00 \%$ \\
\hline $\mathrm{Eu}-154$ & $1.13 \mathrm{E}+02$ & $4.18 \mathrm{E}+06$ & 7.73 E-08 & W & $3.23 \mathrm{E}-01$ & $0.01 \%$ \\
\hline $\mathrm{Eu}-155$ & $1.06 \mathrm{E}+01$ & $3.92 \mathrm{E}+05$ & $1.12 \mathrm{E}-08$ & W & $4.39 \mathrm{E}-03$ & $0.00 \%$ \\
\hline Gd-153 & 5.19 E-19 & 1.92 E-14 & $2.56 \mathrm{E}-09$ & W & 4.92 E-23 & $0.00 \%$ \\
\hline Subtotal: & $3.34 \mathrm{E}+04$ & $1.24 \mathrm{E}+09$ & $1.20 \mathrm{E}-06$ & & $2.07 \mathrm{E}+01$ & $0.57 \%$ \\
\hline \multicolumn{7}{|c|}{ Actinides } \\
\hline U-234 & 3.84 E-01 & $1.42 \mathrm{E}+04$ & $3.58 \mathrm{E}-05$ & Y & $5.09 \mathrm{E}-01$ & $0.01 \%$ \\
\hline U-235 & $1.27 \mathrm{E}-02$ & $4.70 \mathrm{E}+02$ & 3.32 E-05 & Y & $1.56 \mathrm{E}-02$ & $0.00 \%$ \\
\hline U-236 & $7.16 \mathrm{E}-02$ & $2.65 E+03$ & 3.39 E-05 & $\mathrm{Y}$ & $8.98 \mathrm{E}-02$ & $0.00 \%$ \\
\hline
\end{tabular}


Table F-1. Unit Dose Factor with Insoluble Lung Clearances. (3 sheets)

\begin{tabular}{|c|c|c|c|c|c|c|}
\hline \multirow{2}{*}{ Nuclide } & \multirow{2}{*}{$\begin{array}{c}\text { Activity } \\
\text { (Ci/MTU) }\end{array}$} & \multirow{2}{*}{$\begin{array}{c}\text { Activity } \\
(\mathrm{Bq} / \mathrm{gU})\end{array}$} & \multicolumn{2}{|c|}{ Inhalation $\mathrm{DF}^{\mathrm{b}}$} & \multirow{2}{*}{$\begin{array}{c}\text { UD }^{\mathrm{c}} \\
(\mathrm{Sv} / \mathrm{gU})\end{array}$} & \multirow{2}{*}{$\begin{array}{c}\text { Percent of } \\
\text { Total }\end{array}$} \\
& & & $(\mathrm{Sv} / \mathrm{Bq})$ & Class & & \\
\hline $\mathrm{U}-238$ & $3.31 \mathrm{E}-01$ & $1.22 \mathrm{E}+04$ & $3.20 \mathrm{E}-05$ & $\mathrm{Y}$ & $3.92 \mathrm{E}-01$ & $0.01 \%$ \\
\hline Np-237 & $4.66 \mathrm{E}-02$ & $1.72 \mathrm{E}+03$ & $1.46 \mathrm{E}-04$ & W & $2.52 \mathrm{E}-01$ & $0.01 \%$ \\
\hline Pu-238 & $1.33 \mathrm{E}+02$ & $4.92 \mathrm{E}+06$ & $7.79 \mathrm{E}-05$ & Y & $3.83 \mathrm{E}+02$ & $10.53 \%$ \\
\hline Pu-239 & $1.73 \mathrm{E}+02$ & $6.40 \mathrm{E}+06$ & $8.33 \mathrm{E}-05$ & Y & $5.33 \mathrm{E}+02$ & $14.65 \%$ \\
\hline Pu-240 & $1.37 \mathrm{E}+02$ & $5.07 \mathrm{E}+06$ & $8.33 \mathrm{E}-05$ & Y & $4.22 \mathrm{E}+02$ & $11.60 \%$ \\
\hline Pu-241 & $6.82 \mathrm{E}+03$ & $2.52 \mathrm{E}+08$ & $1.34 \mathrm{E}-06$ & Y & $3.38 \mathrm{E}+02$ & $9.30 \%$ \\
\hline Pu-242 & $8.71 \mathrm{E}-02$ & $3.22 \mathrm{E}+03$ & $7.92 \mathrm{E}-05$ & Y & $2.55 \mathrm{E}-01$ & $0.01 \%$ \\
\hline Am-241 & $4.34 \mathrm{E}+02$ & $1.61 \mathrm{E}+07$ & $1.20 \mathrm{E}-04$ & W & $1.93 \mathrm{E}+03$ & $52.93 \%$ \\
\hline Am-242 & $3.71 \mathrm{E}-01$ & $1.37 \mathrm{E}+04$ & $1.58 \mathrm{E}-08$ & W & $2.17 \mathrm{E}-04$ & $0.00 \%$ \\
\hline Am-242m & $3.72 \mathrm{E}-01$ & $1.38 \mathrm{E}+04$ & $1.15 \mathrm{E}-04$ & W & $1.58 \mathrm{E}+00$ & $0.04 \%$ \\
\hline Am-243 & $2.78 \mathrm{E}-01$ & $1.03 \mathrm{E}+04$ & $1.19 \mathrm{E}-04$ & W & $1.22 \mathrm{E}+00$ & $0.03 \%$ \\
\hline Cm-242 & $3.08 \mathrm{E}-01$ & $1.14 \mathrm{E}+04$ & $4.67 \mathrm{E}-06$ & W & $5.32 \mathrm{E}-02$ & $0.00 \%$ \\
\hline Cm-244 & $4.47 \mathrm{E}+00$ & $1.65 \mathrm{E}+05$ & $6.70 \mathrm{E}-05$ & W & $1.11 \mathrm{E}+01$ & $0.30 \%$ \\
\hline Subtotal & $7.70 \mathrm{E}+03$ & $2.85 \mathrm{E}+08$ & $1.03 \mathrm{E}-03$ & $\therefore$ & $3.62 \mathrm{E}+03$ & $99.43 \%$ \\
\hline & & & & Total: & $3.64 \mathrm{E}+03$ & Sv/g U \\
\hline
\end{tabular}

${ }^{a}$ Results are decayed to May 31, 1998. Fuel activities are from HNF-SD-SNF-TI-015 Rev 6, Spent Nuclear Fuel Project Technical Databook, 1998, Fluor Daniel Hanford, Incorporated, Richland, Washington.

'Inhalation dose factors are from Limiting Values of Radionuclide Intake and Air Concentration and Dose Conversion Factors for Inhalation, Submersion, and Ingestion, Federal Guidance Report Number 11 ,

U.S. Environmental Protection Agency, Washington, D.C. (1988). The internal dose factor for tritium was increased by $50 \%$ to include skin absorption.

'The unit dose is the product of the normalized activity and the inhalation dose factor. To convert $\mathrm{Sv} / \mathrm{g}$ to $\mathrm{rem} / \mathrm{g}$ multiply by 100 .

'Krypton- 85 is a noble gas. It does not accumulate in the body; therefore its internal dose factor is zero. The value shown is the external dose rate factor for submersion in an infinite cloud divided by the light activity breathing rate.

'Daughter products are included with parents and not tracked individually. Short half life progeny nuclides not shown are assumed to be in equilibrium with their parent nuclide.

$\mathrm{D}=$ very soluble compounds with lung residence times of days

$\mathrm{DP}=$ daughter product.

MTU $=$ metric ton of uranium.

NA $=$ not applicable.

$\mathrm{W}=$ moderately soluble compounds with lung residence times of weeks

$\mathrm{Y}=$ insoluble compounds with lung residence times of years 
Table F-2. Organ Dose Factors from Inhalation for Insoluble Lung Categories. (3 sheets)

\begin{tabular}{|c|c|c|c|c|c|}
\hline \multirow{2}{*}{ Nuclide } & \multicolumn{5}{|c|}{ Inhalation dose factors, $\mathrm{Sv} / \mathrm{Bq}^{\mathrm{a}}$} \\
\hline & Bone surface & Red marrow & Lungs & Gonads & Remainder \\
\hline \multicolumn{6}{|c|}{ Fission and activation products } \\
\hline $\mathrm{H}-3$ & $2.60 \mathrm{E}-11$ & $2.60 \mathrm{E}-11$ & $2.60 \mathrm{E}-11$ & $2.60 \mathrm{E}-11$ & $2.60 \mathrm{E}-11$ \\
\hline C-14 & 5.64 E-10 & 5.64 E-10 & $5.64 \mathrm{E}-10$ & $5.64 \mathrm{E}-10$ & $5.64 \mathrm{E}-10$ \\
\hline $\mathrm{Fe}-55$ & $1.75 \mathrm{E}-10$ & $1.76 \mathrm{E}-10$ & 1.06 E-09 & $1.79 \mathrm{E}-10$ & $4.37 \mathrm{E}-10$ \\
\hline Co -60 & $1.35 \mathrm{E}-08$ & 1.72 E-08 & 3.45 E-07 & $4.76 \mathrm{E}-09$ & $3.60 \mathrm{E}-08$ \\
\hline $\mathrm{Ni}-59$ & $1.05 \mathrm{E}-10$ & $1.06 \mathrm{E}-10$ & 1.20 E-09 & $1.09 \mathrm{E}-10$ & $1.40 \mathrm{E}-10$ \\
\hline $\mathrm{Ni}-63$ & $2.47 \mathrm{E}-10$ & $2.47 \mathrm{E}-10$ & 3.07 E-09 & $2.47 \mathrm{E}-10$ & 3.67 E- 10 \\
\hline Se-79 & $5.98 \mathrm{E}-10$ & $5.98 \mathrm{E}-10$ & 9.81 E-09 & $5.98 \mathrm{E}-10$ & 3.77 E-09 \\
\hline $\mathrm{Kr}-85$ & 0.0 & 0.0 & 0.0 & 0.0 & 0.0 \\
\hline Sr-90 & 7.27 E-07 & 3.36 E-07 & 3.73 E-09 & $2.64 \mathrm{E}-09$ & $3.36 \mathrm{E}-09$ \\
\hline$Y-90$ & $1.51 \mathrm{E}-11$ & $1.52 \mathrm{E}-11$ & 9.31 E-09 & $5.17 \mathrm{E}-13$ & 3.87 E-09 \\
\hline Zr-93 & $2.38 \mathrm{E}-07$ & $1.93 \mathrm{E}-08$ & 8.72 E-08 & $2.82 \mathrm{E}-12$ & $1.73 \mathrm{E}-10$ \\
\hline $\mathrm{Nb}-93 \mathrm{~m}$ & $2.84 \mathrm{E}-10$ & $1.14 \mathrm{E}-10$ & $6.45 \mathrm{E}-08$ & $1.55 \mathrm{E}-10$ & $3.04 \mathrm{E}-10$ \\
\hline Tc-99 & $3.99 \mathrm{E}-11$ & 3.99 E-11 & 1.67 E-08 & $3.99 \mathrm{E}-11$ & $6.26 \mathrm{E}-10$ \\
\hline Ru-106 & $1.61 \mathrm{E}-09$ & 1.76 E-09 & 1.04 E-06 & $1.30 \mathrm{E}-09$ & $1.20 \mathrm{E}-08$ \\
\hline Rh-106 & $0.0^{b}$ & $0.0^{\mathbf{b}}$ & $0.0^{\mathrm{b}}$ & $0.0^{\mathrm{b}}$ & $0.0^{\mathrm{b}}$ \\
\hline Pd-107 & $1.51 \mathrm{E}-12$ & $5.68 \mathrm{E}-13$ & $2.85 \mathrm{E}-08$ & $1.05 \mathrm{E}-13$ & $9.71 \mathrm{E}-11$ \\
\hline Ag-110 & $0.0^{\mathrm{b}}$ & $0.0^{b}$ & $0.0^{\mathrm{b}}$ & $0.0^{\mathrm{b}}$ & $0.0^{\mathrm{b}}$ \\
\hline $\mathrm{Ag}-110 \mathrm{~m}$ & 5.19 E-09 & 6.74 E-09 & $1.20 \mathrm{E}-07$ & $2.43 \mathrm{E}-09$ & $1.51 \mathrm{E}-08$ \\
\hline $\mathrm{Cd}-113 \mathrm{~m}$ & 4.72 E-09 & 4.72 E-09 & 4.09 E-07 & 4.72 E-09 & $1.86 \mathrm{E}-07$ \\
\hline In-113m & $9.38 \mathrm{E}-13$ & $1.41 \mathrm{E}-12$ & $5.83 \mathrm{E}-11$ & $8.23 \mathrm{E}-13$ & $4.99 \mathrm{E}-12$ \\
\hline $\mathrm{Sn}-113$ & $1.32 \mathrm{E}-09$ & $7.71 \mathrm{E}-10$ & $1.84 \mathrm{E}-08$ & $3.16 \mathrm{E}-10$ & 1.38 E-09 \\
\hline $\mathrm{Sn}-119 \mathrm{~m}$ & 1.10 E-09 & $4.62 \mathrm{E}-10$ & $1.15 \mathrm{E}-08$ & 7.14 E-11 & $6.28 \mathrm{E}-10$ \\
\hline $\mathrm{Sn}-121 \mathrm{~m}$ & 4.06 E-09 & $1.50 \mathrm{E}-09$ & $2.08 \mathrm{E}-08$ & $1.97 \mathrm{E}-10$ & $1.10 \mathrm{E}-09$ \\
\hline Sn-123 & 3.75 E-09 & 1.36 E-09 & $6.11 \mathrm{E}-08$ & $1.81 \mathrm{E}-10$ & 3.70 E-09 \\
\hline $\mathrm{Sn}-126$ & $3.33 \mathrm{E}-08$ & $1.69 \mathrm{E}-08$ & $1.51 \mathrm{E}-07$ & 4.95 E-09 & $1.20 \mathrm{E}-08$ \\
\hline
\end{tabular}


Table F-2. Organ Dose Factors from Inhalation for Insoluble Lung Categories. (3 sheets)

\begin{tabular}{|c|c|c|c|c|c|}
\hline \multirow{2}{*}{ Nuclide } & \multicolumn{5}{|c|}{ Inhalation dose factors, Sv/Bq } \\
\cline { 2 - 7 } & Bone surface & Red marrow & Lungs & Gonads & Remainder \\
\hline Sb-125 & 9.78 E-10 & $5.35 \mathrm{E}-10$ & $2.17 \mathrm{E}-08$ & $3.60 \mathrm{E}-10$ & $1.45 \mathrm{E}-09$ \\
\hline $\mathrm{Sb}-126$ & $6.75 \mathrm{E}-10$ & $7.97 \mathrm{E}-10$ & $1.38 \mathrm{E}-08$ & $1.32 \mathrm{E}-09$ & $3.19 \mathrm{E}-09$ \\
\hline Sb-126m & $7.12 \mathrm{E}-13$ & $8.63 \mathrm{E}-13$ & $5.57 \mathrm{E}-11$ & $4.91 \mathrm{E}-13$ & $2.12 \mathrm{E}-12$ \\
\hline Te-123m & $2.40 \mathrm{E}-08$ & $2.41 \mathrm{E}-09$ & $1.27 \mathrm{E}-08$ & $1.88 \mathrm{E}-10$ & $8.06 \mathrm{E}-10$ \\
\hline Te-125m & $1.18 \mathrm{E}-08$ & $1.15 \mathrm{E}-09$ & $1.04 \mathrm{E}-08$ & $7.93 \mathrm{E}-11$ & $6.75 \mathrm{E}-10$ \\
\hline Te-127 & $4.09 \mathrm{E}-12$ & $4.09 \mathrm{E}-12$ & $4.27 \mathrm{E}-10$ & $2.02 \mathrm{E}-12$ & $1.11 \mathrm{E}-10$ \\
\hline Te-127m & $2.04 \mathrm{E}-08$ & $5.36 \mathrm{E}-09$ & $3.34 \mathrm{E}-08$ & $1.10 \mathrm{E}-10$ & $1.66 \mathrm{E}-09$ \\
\hline $\mathrm{I}-129$ & $1.38 \mathrm{E}-10$ & $1.40 \mathrm{E}-10$ & $3.14 \mathrm{E}-10$ & $8.69 \mathrm{E}-11$ & $1.18 \mathrm{E}-10$ \\
\hline $\mathrm{Cs}-134$ & $1.10 \mathrm{E}-08$ & $1.18 \mathrm{E}-08$ & $1.18 \mathrm{E}-08$ & $1.30 \mathrm{E}-08$ & $1.39 \mathrm{E}-08$ \\
\hline $\mathrm{Cs}-135$ & $1.20 \mathrm{E}-09$ & $1.20 \mathrm{E}-09$ & $1.41 \mathrm{E}-09$ & $1.20 \mathrm{E}-09$ & $1.20 \mathrm{E}-09$ \\
\hline $\mathrm{Cs}-137$ & $7.94 \mathrm{E}-09$ & $8.30 \mathrm{E}-09$ & $8.82 \mathrm{E}-09$ & $8.76 \mathrm{E}-09$ & $9.12 \mathrm{E}-09$ \\
\hline Ba-137m & $0.0^{\mathrm{b}}$ & $0.0^{\mathrm{b}}$ & $0.0^{\mathrm{b}}$ & $0.0^{\mathrm{b}}$ & $0.0^{\mathrm{b}}$ \\
\hline $\mathrm{Ce}-144$ & $4.72 \mathrm{E}-09$ & $2.88 \mathrm{E}-09$ & $7.91 \mathrm{E}-07$ & $2.39 \mathrm{E}-10$ & $1.91 \mathrm{E}-08$ \\
\hline $\mathrm{Pr}-144$ & $1.47 \mathrm{E}-14$ & $1.38 \mathrm{E}-14$ & $9.40 \mathrm{E}-11$ & $2.41 \mathrm{E}-15$ & $1.40 \mathrm{E}-12$ \\
\hline $\mathrm{Pr}-144 \mathrm{~m}$ & $0.0^{\mathrm{b}}$ & $0.0^{\mathrm{b}}$ & $0.0^{\mathrm{b}}$ & $0.0^{\mathrm{b}}$ & $0.0^{\mathrm{b}}$ \\
\hline $\mathrm{Pm}-147$ & $2.01 \mathrm{E}-08$ & $1.61 \mathrm{E}-09$ & $7.74 \mathrm{E}-08$ & $8.25 \mathrm{E}-15$ & $1.56 \mathrm{E}-09$ \\
\hline $\mathrm{Sm}-151$ & $1.38 \mathrm{E}-07$ & $1.10 \mathrm{E}-08$ & $3.26 \mathrm{E}-09$ & $4.03 \mathrm{E}-14$ & $7.51 \mathrm{E}-09$ \\
\hline $\mathrm{Eu}-152$ & $2.40 \mathrm{E}-07$ & $7.91 \mathrm{E}-08$ & $5.76 \mathrm{E}-08$ & $1.31 \mathrm{E}-08$ & $9.99 \mathrm{E}-08$ \\
\hline $\mathrm{Eu}-154$ & $5.23 \mathrm{E}-07$ & $1.06 \mathrm{E}-07$ & $7.92 \mathrm{E}-08$ & $1.17 \mathrm{E}-08$ & $1.13 \mathrm{E}-07$ \\
\hline $\mathrm{Eu}-155$ & $1.52 \mathrm{E}-07$ & $1.43 \mathrm{E}-08$ & $1.19 \mathrm{E}-08$ & $3.56 \mathrm{E}-10$ & $1.11 \mathrm{E}-08$ \\
\hline $\mathrm{Gd}-153$ & $2.15 \mathrm{E}-08$ & $2.71 \mathrm{E}-09$ & $7.75 \mathrm{E}-09$ & $1.93 \mathrm{E}-10$ & $1.90 \mathrm{E}-09$ \\
\hline & & & Actinides & & \\
\hline $\mathrm{U}-234$ & $1.13 \mathrm{E}-06$ & $7.22 \mathrm{E}-08$ & $2.98 \mathrm{E}-04$ & $2.65 \mathrm{E}-09$ & $1.06 \mathrm{E}-07$ \\
\hline $\mathrm{U}-235$ & $1.05 \mathrm{E}-06$ & $7.15 \mathrm{E}-08$ & $2.76 \mathrm{E}-04$ & $2.85 \mathrm{E}-09$ & $1.02 \mathrm{E}-07$ \\
\hline $\mathrm{U}-236$ & $1.07 \mathrm{E}-06$ & $6.83 \mathrm{E}-08$ & $2.82 \mathrm{E}-04$ & $2.51 \mathrm{E}-09$ & $1.00 \mathrm{E}-07$ \\
\hline $\mathrm{U}-238$ & $1.01 \mathrm{E}-06$ & $6.91 \mathrm{E}-08$ & $2.66 \mathrm{E}-04$ & $2.44 \mathrm{E}-09$ & $1.02 \mathrm{E}-07$ \\
\hline
\end{tabular}


Table F-2. Organ Dose Factors from Inhalation for Insoluble Lung Categories. (3 sheets)

\begin{tabular}{|c|c|c|c|c|c|}
\hline \multirow{2}{*}{ Nuclide } & \multicolumn{5}{|c|}{ Inhalation dose factors, Sv/Bq } \\
\cline { 2 - 7 } & Bone surface & Red marrow & Lungs & Gonads & Remainder \\
\hline $\mathrm{Np}-237$ & $3.27 \mathrm{E}-03$ & $2.62 \mathrm{E}-04$ & $1.61 \mathrm{E}-05$ & $2.96 \mathrm{E}-05$ & $2.34 \mathrm{E}-05$ \\
\hline $\mathrm{Pu}-238$ & $7.25 \mathrm{E}-04$ & $5.80 \mathrm{E}-05$ & $3.20 \mathrm{E}-04$ & $1.04 \mathrm{E}-05$ & $2.74 \mathrm{E}-05$ \\
\hline $\mathrm{Pu}-239$ & $8.21 \mathrm{E}-04$ & $6.57 \mathrm{E}-05$ & $3.23 \mathrm{E}-04$ & $1.20 \mathrm{E}-05$ & $3.02 \mathrm{E}-05$ \\
\hline $\mathrm{Pu}-240$ & $8.21 \mathrm{E}-04$ & $6.57 \mathrm{E}-05$ & $3.23 \mathrm{E}-04$ & $1.20 \mathrm{E}-05$ & $3.02 \mathrm{E}-05$ \\
\hline $\mathrm{Pu}-241$ & $1.78 \mathrm{E}-05$ & $1.43 \mathrm{E}-06$ & $3.18 \mathrm{E}-06$ & $2.76 \mathrm{E}-07$ & $6.02 \mathrm{E}-07$ \\
\hline $\mathrm{Pu}-242$ & $7.81 \mathrm{E}-04$ & $6.25 \mathrm{E}-05$ & $3.07 \mathrm{E}-04$ & $1.14 \mathrm{E}-05$ & $2.86 \mathrm{E}-05$ \\
\hline $\mathrm{Am}-241$ & $2.17 \mathrm{E}-03$ & $1.74 \mathrm{E}-04$ & $1.84 \mathrm{E}-05$ & $3.25 \mathrm{E}-05$ & $7.82 \mathrm{E}-05$ \\
\hline $\mathrm{Am}-242$ & $1.65 \mathrm{E}-07$ & $1.32 \mathrm{E}-08$ & $5.20 \mathrm{E}-08$ & $1.94 \mathrm{E}-09$ & $8.54 \mathrm{E}-09$ \\
\hline $\mathrm{Am}-242 \mathrm{~m}$ & $2.12 \mathrm{E}-03$ & $1.69 \mathrm{E}-04$ & $4.20 \mathrm{E}-06$ & $3.21 \mathrm{E}-05$ & $7.48 \mathrm{E}-05$ \\
\hline $\mathrm{Am}-243$ & $2.17 \mathrm{E}-03$ & $1.73 \mathrm{E}-04$ & $1.78 \mathrm{E}-05$ & $3.26 \mathrm{E}-05$ & $7.74 \mathrm{E}-05$ \\
\hline $\mathrm{Cm}-242$ & $4.87 \mathrm{E}-05$ & $3.90 \mathrm{E}-06$ & $1.55 \mathrm{E}-05$ & $5.70 \mathrm{E}-07$ & $2.45 \mathrm{E}-06$ \\
\hline $\mathrm{Cm}-244$ & $1.17 \mathrm{E}-03$ & $9.38 \mathrm{E}-05$ & $1.93 \mathrm{E}-05$ & $1.59 \mathrm{E}-05$ & $4.78 \mathrm{E}-05$ \\
\hline
\end{tabular}

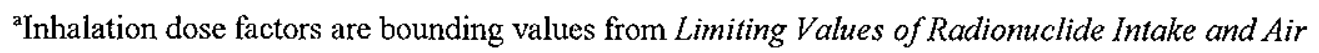
Concentration and Dose Conversion Factors for Inhalation, Submersion, and Ingestion, Federal Guidance Report Number 11, U.S. Environmental Protection Agency, Washington, D.C. (1988). The internal dose factor for tritium was increased by $50 \%$ to include absorption through the skin. To convert Sv/Bq to $\mathrm{mrem} / \mathrm{pCi}$ multiply by 3700 .

baughter products are included with parents and not tracked individually. Short half life progeny nuclides not shown are assumed to be in equilibrium with their parent nuclide. 
Table F-3. Unit Dose Factors for Organs for Insoluble Lung Categories. (3 sheets)

\begin{tabular}{|c|c|c|c|c|c|}
\hline \multirow{2}{*}{ Nuclide } & \multicolumn{5}{|c|}{ Organ unit dose factors, $\mathrm{Sv} / \mathrm{g}^{\mathrm{a}}$} \\
\hline & Bone surface & Red marrow & Lungs & Gonads & Remainder \\
\hline \multicolumn{6}{|c|}{ Fission and activation products } \\
\hline $\mathrm{H}-3$ & $2.51 \mathrm{E}-05$ & $2.51 \mathrm{E}-05$ & $2.51 \mathrm{E}-05$ & $2.51 \mathrm{E}-05$ & $2.51 \mathrm{E}-05$ \\
\hline C-14 & $1.15 \mathrm{E}-05$ & $1.15 \mathrm{E}-05$ & $1.15 \mathrm{E}-05$ & $1.15 \mathrm{E}-05$ & $1.15 \mathrm{E}-05$ \\
\hline $\mathrm{Fe}-55$ & $3.50 \mathrm{E}-06$ & 3.52 E-06 & 2.12 E-05 & $3.58 \mathrm{E}-06$ & $8.75 \mathrm{E}-06$ \\
\hline $\mathrm{Co}-60$ & 1.04 E-03 & $1.33 \mathrm{E}-03$ & $2.67 \mathrm{E}-02$ & $3.68 \mathrm{E}-04$ & $2.78 \mathrm{E}-03$ \\
\hline $\mathrm{Ni}-59$ & 1.24 E-07 & $1.25 \mathrm{E}-07$ & $1.41 \mathrm{E}-06$ & $1.28 \mathrm{E}-07$ & $1.65 \mathrm{E}-07$ \\
\hline $\mathrm{Ni}-63$ & $3.17 \mathrm{E}-05$ & $3.17 \mathrm{E}-05$ & 3.94 E-04 & $3.17 \mathrm{E}-05$ & $4.71 \mathrm{E}-05$ \\
\hline Se-79 & $1.45 \mathrm{E}-06$ & $1.45 \mathrm{E}-06$ & $2.37 \mathrm{E}-05$ & $1.45 \mathrm{E}-06$ & 9.12 E-06 \\
\hline $\mathrm{Kr}-85$ & 0.0 & 0.0 & 0.0 & 0.0 & 0.0 \\
\hline $\operatorname{Sr}-90$ & $1.86 E+02$ & 8.62 E+01 & $9.56 \mathrm{E}-01$ & $6.77 \mathrm{E}-01$ & $8.62 \mathrm{E}-01$ \\
\hline$Y-90$ & $3.87 \mathrm{E}-03$ & $3.90 \mathrm{E}-03$ & $2.39 \mathrm{E}+00$ & 1.33 E-04 & 9.92 E-01 \\
\hline $\mathrm{Zr}-93$ & $2.60 \mathrm{E}-03$ & $2.11 \mathrm{E}-04$ & $9.52 \mathrm{E}-04$ & $3.08 \mathrm{E}-08$ & $1.89 \mathrm{E}-06$ \\
\hline $\mathrm{Nb}-93 \mathrm{~m}$ & $2.03 \mathrm{E}-06$ & 8.14 E-07 & $4.61 \mathrm{E}-04$ & $1.11 \mathrm{E}-06$ & 2.17 E-06 \\
\hline Tc-99 & $3.23 \mathrm{E}-06$ & $3.23 \mathrm{E}-06$ & $1.35 \mathrm{E}-03$ & $3.23 \mathrm{E}-06$ & 5.07 E-05 \\
\hline Ru-106 & 1.52 E-06 & 1.67 E-06 & $9.85 \mathrm{E}-04$ & $1.23 \mathrm{E}-06$ & $1.14 \mathrm{E}-05$ \\
\hline Rh-106 & $0.0^{\mathrm{b}}$ & $0.0^{\mathrm{b}}$ & $0.0^{\mathrm{b}}$ & $0.0^{\mathrm{b}}$ & $0.0^{\mathrm{b}}$ \\
\hline Pd-107 & 8.72 E-10 & $3.28 \mathrm{E}-10$ & $1.65 \mathrm{E}-05$ & $6.06 \mathrm{E}-11$ & $5.60 \mathrm{E}-08$ \\
\hline $\mathrm{Ag}-110$ & $0.0^{\mathrm{b}}$ & $0.0^{\mathrm{b}}$ & $0.0^{b}$ & $0.0^{b}$ & $0.0^{\mathrm{b}}$ \\
\hline $\mathrm{Ag}-110 \mathrm{~m}$ & $1.04 \mathrm{E}-\mathrm{I} 1$ & 1.34 E-11 & $2.39 \mathrm{E}-10$ & $4.85 \mathrm{E}-12$ & $3.01 \mathrm{E}-11$ \\
\hline $\mathrm{Cd}-113 \mathrm{~m}$ & $4.85 \mathrm{E}-04$ & 4.85 E-04 & $4.21 \mathrm{E}-02$ & $4.85 \mathrm{E}-04$ & $1.91 \mathrm{E}-02$ \\
\hline In- $113 m$ & $4.72 \mathrm{E}-27$ & $7.10 \mathrm{E}-27$ & $2.93 \mathrm{E}-25$ & 4.14 E-27 & $2.51 \mathrm{E}-26$ \\
\hline $\mathrm{Sn}-113$ & $6.64 \mathrm{E}-24$ & $3.88 \mathrm{E}-24$ & $9.26 \mathrm{E}-23$ & $1.59 \mathrm{E}-24$ & $6.94 \mathrm{E}-24$ \\
\hline $\mathrm{Sn}-119 \mathrm{~m}$ & $2.50 \mathrm{E}-12$ & $1.05 \mathrm{E}-12$ & $2.61 \mathrm{E}-11$ & $1.62 \mathrm{E}-13$ & $1.43 \mathrm{E}-12$ \\
\hline $\mathrm{Sn}-121 \mathrm{~m}$ & $9.42 \mathrm{E}-06$ & 3.47 E-06 & $4.83 \mathrm{E}-05$ & $4.56 \mathrm{E}-07$ & $2.55 \mathrm{E}-06$ \\
\hline $\mathrm{Sn}-123$ & $2.39 \mathrm{E}-20$ & $8.66 \mathrm{E}-21$ & $3.89 \mathrm{E}-19$ & $1.15 \mathrm{E}-21$ & $2.35 \mathrm{E}-20$ \\
\hline Sn-126 & $1.59 \mathrm{E}-04$ & 8.07 E-05 & $7.21 \mathrm{E}-04$ & $2.36 \mathrm{E}-05$ & $5.73 \mathrm{E}-05$ \\
\hline
\end{tabular}


Table F-3. Unit Dose Factors for Organs for Insoluble Lung Categories. (3 sheets)

\begin{tabular}{|c|c|c|c|c|c|}
\hline \multirow{2}{*}{ Nuclide } & \multicolumn{5}{|c|}{ Organ unit dose factors, Sv/g } \\
\cline { 2 - 6 } & Bone surface & Red marrow & Lungs & Gonads & Remainder \\
\hline Sb-125 & 0.0 & 0.0 & 0.0 & 0.0 & 0.0 \\
\hline Sb-126 & $4.52 \mathrm{E}-07$ & $5.34 \mathrm{E}-07$ & $9.24 \mathrm{E}-06$ & $8.84 \mathrm{E}-07$ & $2.14 \mathrm{E}-06$ \\
\hline Sb-126m & $3.40 \mathrm{E}-09$ & $4.12 \mathrm{E}-09$ & $2.66 \mathrm{E}-07$ & $2.34 \mathrm{E}-09$ & $1.01 \mathrm{E}-08$ \\
\hline Te-123m & $1.33 \mathrm{E}-24$ & $1.34 \mathrm{E}-25$ & $7.05 \mathrm{E}-25$ & $1.04 \mathrm{E}-26$ & $4.47 \mathrm{E}-26$ \\
\hline Te-125m & 0.0 & 0.0 & 0.0 & 0.0 & 0.0 \\
\hline Te-127 & $3.21 \mathrm{E}-26$ & $3.21 \mathrm{E}-26$ & $3.35 \mathrm{E}-24$ & $1.58 \mathrm{E}-26$ & $8.71 \mathrm{E}-25$ \\
\hline Te-127m & $1.63 \mathrm{E}-22$ & $4.28 \mathrm{E}-23$ & $2.67 \mathrm{E}-22$ & $8.79 \mathrm{E}-25$ & $1.33 \mathrm{E}-23$ \\
\hline $\mathrm{I}-129$ & $2.63 \mathrm{E}-08$ & $2.67 \mathrm{E}-08$ & $5.99 \mathrm{E}-08$ & $1.66 \mathrm{E}-08$ & $2.25 \mathrm{E}-08$ \\
\hline Cs-134 & $2.63 \mathrm{E}-03$ & $2.82 \mathrm{E}-03$ & $2.82 \mathrm{E}-03$ & $3.11 \mathrm{E}-03$ & $3.33 \mathrm{E}-03$ \\
\hline Cs-135 & $2.68 \mathrm{E}-06$ & $2.68 \mathrm{E}-06$ & $3.15 \mathrm{E}-06$ & $2.68 \mathrm{E}-06$ & $2.68 \mathrm{E}-06$ \\
\hline Cs-137 & $2.84 \mathrm{E}+00$ & $2.97 \mathrm{E}+00$ & $3.15 \mathrm{E}+00$ & $3.13 \mathrm{E}+00$ & $3.26 \mathrm{E}+00$ \\
\hline Ba-137m & $0.0^{\mathrm{b}}$ & $0.0^{\mathrm{b}}$ & $0.0^{\mathrm{b}}$ & $0.0^{\mathrm{b}}$ & $0.0^{\mathrm{b}}$ \\
\hline $\mathrm{Ce}-144$ & $1.38 \mathrm{E}-07$ & $8.43 \mathrm{E}-08$ & $2.32 \mathrm{E}-05$ & $6.99 \mathrm{E}-09$ & $5.59 \mathrm{E}-07$ \\
\hline Pr-144 & $4.25 \mathrm{E}-13$ & $3.99 \mathrm{E}-13$ & $2.72 \mathrm{E}-09$ & $6.97 \mathrm{E}-14$ & $4.05 \mathrm{E}-11$ \\
\hline Pr-144m & $0.0^{\mathrm{b}}$ & $0.0^{\mathrm{b}}$ & $0.0^{\mathrm{b}}$ & $0.0^{\mathrm{b}}$ & $0.0^{\mathrm{b}}$ \\
\hline Pm-147 & $8.11 \mathrm{E}-02$ & $6.49 \mathrm{E}-03$ & $3.12 \mathrm{E}-01$ & $3.33 \mathrm{E}-08$ & $6.29 \mathrm{E}-03$ \\
\hline Sm-151 & $5.21 \mathrm{E}-01$ & $4.15 \mathrm{E}-02$ & $1.23 \mathrm{E}-02$ & $1.52 \mathrm{E}-07$ & $2.83 \mathrm{E}-02$ \\
\hline Eu-152 & $7.50 \mathrm{E}-03$ & $2.47 \mathrm{E}-03$ & $1.80 \mathrm{E}-03$ & $4.10 \mathrm{E}-04$ & $3.12 \mathrm{E}-03$ \\
\hline Eu-154 & $2.19 \mathrm{E}+00$ & $4.43 \mathrm{E}-01$ & $3.31 \mathrm{E}-01$ & $4.89 \mathrm{E}-02$ & $4.72 \mathrm{E}-01$ \\
\hline Eu-155 & $5.96 \mathrm{E}-02$ & $5.61 \mathrm{E}-03$ & $4.67 \mathrm{E}-03$ & $1.40 \mathrm{E}-04$ & $4.35 \mathrm{E}-03$ \\
\hline Gd-153 & $4.13 \mathrm{E}-22$ & $5.20 \mathrm{E}-23$ & $1.49 \mathrm{E}-22$ & $3.71 \mathrm{E}-24$ & $3.65 \mathrm{E}-23$ \\
\hline Subtotal: & $1.92 \mathrm{E}+02$ & $8.96 \mathrm{E}+01$ & $7.23 \mathrm{E}+00$ & $3.86 \mathrm{E}+00$ & $5.65 \mathrm{E}+00$ \\
\hline & & & Actinides & & \\
\hline U-234 & $1.61 \mathrm{E}-02$ & $1.03 \mathrm{E}-03$ & $4.23 \mathrm{E}+00$ & $3.77 \mathrm{E}-05$ & $1.51 \mathrm{E}-03$ \\
\hline U-235 & $4.93 \mathrm{E}-04$ & $3.36 \mathrm{E}-05$ & $1.30 \mathrm{E}-01$ & $1.34 \mathrm{E}-06$ & $4.81 \mathrm{E}-05$ \\
\hline U-236 & $2.83 \mathrm{E}-03$ & $1.81 \mathrm{E}-04$ & $7.47 \mathrm{E}-01$ & $6.65 \mathrm{E}-06$ & $2.65 \mathrm{E}-04$ \\
\hline
\end{tabular}


Table F-3. Unit Dose Factors for Organs for Insoluble Lung Categories. (3 sheets)

\begin{tabular}{|c|c|c|c|c|c|}
\hline \multirow{2}{*}{ Nuclide } & \multicolumn{5}{|c|}{ Organ unit dose factors, Sv/g } \\
\cline { 2 - 7 } & Bone surface & Red marrow & Lungs & Gonads & Remainder \\
\hline U-238 & $1.24 \mathrm{E}-02$ & $8.46 \mathrm{E}-04$ & $3.26 \mathrm{E}+00$ & $2.99 \mathrm{E}-05$ & $1.25 \mathrm{E}-03$ \\
\hline $\mathrm{Np}-237$ & $5.64 \mathrm{E}+00$ & $4.52 \mathrm{E}-01$ & $2.78 \mathrm{E}-02$ & $5.10 \mathrm{E}-02$ & $4.03 \mathrm{E}-02$ \\
\hline Pu-238 & $3.57 \mathrm{E}+03$ & $2.85 \mathrm{E}+02$ & $1.57 \mathrm{E}+03$ & $5.12 \mathrm{E}+01$ & $1.35 \mathrm{E}+02$ \\
\hline Pu-239 & $5.26 \mathrm{E}+03$ & $4.21 \mathrm{E}+02$ & $2.07 \mathrm{E}+03$ & $7.68 \mathrm{E}+01$ & $1.93 \mathrm{E}+02$ \\
\hline Pu-240 & $4.16 \mathrm{E}+03$ & $3.33 \mathrm{E}+02$ & $1.64 \mathrm{E}+03$ & $6.08 \mathrm{E}+01$ & $1.53 \mathrm{E}+02$ \\
\hline Pu-241 & $4.49 \mathrm{E}+03$ & $3.61 \mathrm{E}+02$ & $8.02 \mathrm{E}+02$ & $6.96 \mathrm{E}+01$ & $1.52 \mathrm{E}+02$ \\
\hline Pu-242 & $2.52 \mathrm{E}+00$ & $2.01 \mathrm{E}-01$ & $9.89 \mathrm{E}-01$ & $3.67 \mathrm{E}-02$ & $9.22 \mathrm{E}-02$ \\
\hline Am-241 & $3.48 \mathrm{E}+04$ & $2.79 \mathrm{E}+03$ & $2.95 \mathrm{E}+02$ & $5.22 \mathrm{E}+02$ & $1.26 \mathrm{E}+03$ \\
\hline Am-242 & $2.26 \mathrm{E}-03$ & $1.81 \mathrm{E}-04$ & $7.14 \mathrm{E}-04$ & $2.66 \mathrm{E}-05$ & $1.17 \mathrm{E}-04$ \\
\hline Am-242m & $2.92 \mathrm{E}+01$ & $2.33 \mathrm{E}+00$ & $5.78 \mathrm{E}-02$ & $4.42 \mathrm{E}-01$ & $1.03 \mathrm{E}+00$ \\
\hline Am-243 & $2.23 \mathrm{E}+01$ & $1.78 \mathrm{E}+00$ & $1.83 \mathrm{E}-01$ & $3.35 \mathrm{E}-01$ & $7.96 \mathrm{E}-01$ \\
\hline Cm-242 & $5.55 \mathrm{E}-01$ & $4.44 \mathrm{E}-02$ & $1.77 \mathrm{E}-01$ & $6.50 \mathrm{E}-03$ & $2.79 \mathrm{E}-02$ \\
\hline Cm-244 & $1.94 \mathrm{E}+02$ & $1.55 \mathrm{E}+01$ & $3.19 \mathrm{E}+00$ & $2.63 \mathrm{E}+00$ & $7.91 \mathrm{E}+00$ \\
\hline Subtotal: & $5.26 \mathrm{E}+04$ & $4.21 \mathrm{E}+03$ & $6.39 \mathrm{E}+03$ & $7.84 \mathrm{E}+02$ & $1.90 \mathrm{E}+03$ \\
\hline SNF Total: & $5.28 \mathrm{E}+04$ & $4.30 \mathrm{E}+03$ & $6.40 \mathrm{E}+03$ & $7.88 \mathrm{E}+02$ & $1.90 \mathrm{E}+03$ \\
\hline
\end{tabular}

${ }^{\text {aT }}$ The unit dose is the product of the normalized activity (Table F-1) and the inhalation dose factor (Table F-2). To convert Sv/g to rem/g multiply by 100 .

baughter products are included with parents and not tracked individually. Short half life progeny nuclides not shown are assumed to be in equilibrium with their parent nuclide. 
HNF-SD-SNF-TI-059 REV 2

Table F-4. Summary of Unit Dose Factors

\begin{tabular}{|l|c|c|}
\hline \multicolumn{1}{|c|}{ Type of Unit Dose } & Bounding case & Realistic case \\
\hline EDE & $4,380 \mathrm{~Sv} / \mathrm{g}$ & $3,640 \mathrm{~Sv} / \mathrm{g}$ \\
\hline Bone surface & $79,400 \mathrm{~Sv} / \mathrm{g}$ & $52,800 \mathrm{~Sv} / \mathrm{g}$ \\
\hline Red marrow & $6,440 \mathrm{~Sv} / \mathrm{g}$ & $4,300 \mathrm{~Sv} / \mathrm{g}$ \\
\hline Lung & $606 \mathrm{~Sv} / \mathrm{g}$ & $6,400 \mathrm{~Sv} / \mathrm{g}$ \\
\hline Gonads & $1,200 \mathrm{~Sv} / \mathrm{g}$ & $788 \mathrm{~Sv} / \mathrm{g}$ \\
\hline Remainder & $2,810 \mathrm{~Sv} / \mathrm{g}$ & $1,900 \mathrm{~Sv} / \mathrm{g}$ \\
\hline Air submersion & $0.0303 \mathrm{~Sv} / \mathrm{g}$ & $0.0303 \mathrm{~Sv} / \mathrm{g}$ \\
\hline
\end{tabular}

The EDE and organ values for unit dose are from inhalation.only. The air submersion value for unit dose is external dose from submersion in the plume. The "Bounding case" uses lung solubilities with the largest inhalation dose factors. The "Realistic case" uses insoluble lung solubility assumptions.

$\mathrm{EDE}=$ effective dose equivalent. 
HNF-SD-SNF-TI-059 REV 2

APPENDIX G

GENII INPUT FILES FOR INGESTION DOSE CALCULATIONS 
HNF-SD-SNF-TI-059 REV 2

This page intentionally left blank. 


\section{Input File for GENII -- Inhale, External, and Milk Dose Factors}

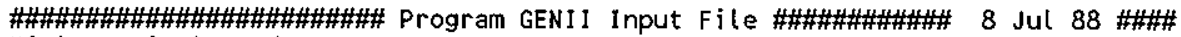
Title: Animal Products

IGENII \24A.IN Created on 01-06-1998 at 07:30

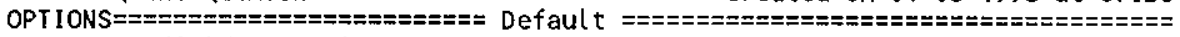

$F$ Near-field scenario? (Far-field) NEAR-FIELD: narrowly-focused

$F$ Population dose? (Individual) release, single site

T Acute release? (Chronic) FAR-FIELD: wide-scale release, Maximum Individual data set used multiple sites

Complete

TRANSPORT OPTIONS=========== Section EXPOSURE PATHWAY OPTIONS==== Section

$\begin{array}{lllll}\text { T Air Transport } & 1 & \text { F Finite plume, external } & 5 \\ \text { F Surface Water Transport } & 2 & \text { F Infinite plume, external } & 5 \\ \text { F Biotic Transport (near-field) } & 3,4 & \text { T Ground, external } & 5 \\ \text { F Waste Form Degradation (near) } & 3,4 & \text { F Recreation, external } & 5 \\ & & \text { T Inhalation uptake } & 5,6 \\ \text { REPORT OPTIONS===:===E=:============= } & \text { F Drinking water ingestion } & 7,8 \\ \text { T Report AEDE only } & & \text { F Aquatic foods ingestion } & 7,8 \\ \text { F Report by radionucl ide } & & \text { F Terrestrial foods ingestion } & 7,9 \\ \text { T Report by exposure pathway } & & \text { T Animal product ingestion } & 7,10 \\ \text { F Debug report on screen } & & \text { F Inadvertent soil ingestion } & \end{array}$

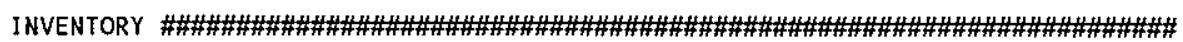

5 Inventory input activity units: (1-pCi $2-\mu \mathrm{Ci} \quad 3-\mathrm{mCi} \quad 4-\mathrm{Ci} \quad 5-\mathrm{Bq})$

0 Surface soil source units $\left(1-\mathrm{m}^{2} 2-\mathrm{m} 3 \quad 3-\mathrm{kg}\right)$

Equilibrium question goes here

\begin{tabular}{|c|c|c|c|c|c|c|}
\hline Use when & $\begin{array}{r}--- \text { Release Ter } \\
\text { transport sel }\end{array}$ & $\begin{array}{l}\text { ms } \cdots-1 . \\
\text { ected }\end{array}$ & $\begin{array}{c}\text { near-field sc }\end{array}$ & $\begin{array}{l}\text { Conce } \\
\text { enario }\end{array}$ & $\begin{array}{l}\text { ation } \\
\text { ption }\end{array}$ & - \\
\hline $\begin{array}{l}\text { Rel ease } \\
\text { Radio- } \\
\text { nuclide }\end{array}$ & $\begin{array}{l}\text { Surface } \\
\text { Water } \\
\text { /yr }\end{array}$ & $\begin{array}{l}\text { Buried } \\
\text { Waste } \\
/ \mathrm{m} 3\end{array}$ & $\begin{array}{l}\text { Surface } \\
\text { Soil } \\
\text { /unit }\end{array}$ & $\begin{array}{l}\text { Deep } \\
\text { Soil } \\
\text { /m3 }\end{array}$ & $\begin{array}{l}\text { Ground } \\
\text { Water } \\
\text { /L }\end{array}$ & $\begin{array}{l}\text { Surface } \\
\text { Water } \\
\text { / }\end{array}$ \\
\hline
\end{tabular}

H $3 \quad 9.7 \mathrm{E}+05$

C $14 \quad 2.0 \mathrm{E}+04$

FE55 $2.0 \mathrm{E}+04$

CO60 $7.7 \mathrm{E}+04$

NI59 $\quad 1.2 \mathrm{E}+03$

NI63 1.3E+05

SE79 2.4E+03

KR85 $1.4 \mathrm{E}+07$

SR90 2.6E+08

Y $90 \quad 2.6 \mathrm{E}+08$

ZR93 1.1E+04

NB93M 7.1E+03

TC99 8.1E+04

RU106 $9.5 \mathrm{E}+02$

PD107 $\quad 5.8 \mathrm{E}+02$

AG110M 2.0E-03

CD113M 1.0E+05

SN113 5.0E-15

IN113M 5.0E-15

SN119M 2.3E-03

SN121M 2.3E+03

SN121 1.8E+03

SN123 6.4E-12

SN126 4.8E+03

SB126M $\quad 4.8 \mathrm{E}+03$

SB126 $6.7 \mathrm{E}+02$

TE123M 5.6E-17

TE127M 8.0E-15

TE127 7.8E-15

I $129 \quad 1.9 \mathrm{E}+02$

CS134 2.4E+05

Cs $135 \quad 2.2 \mathrm{E}+03$

CS137 3.6E+08

CE144 2.9E+01

PR 144M 3.5E-01

PR144 2.9E+01 
HNF-SD-SNF-TI-059 REV 2

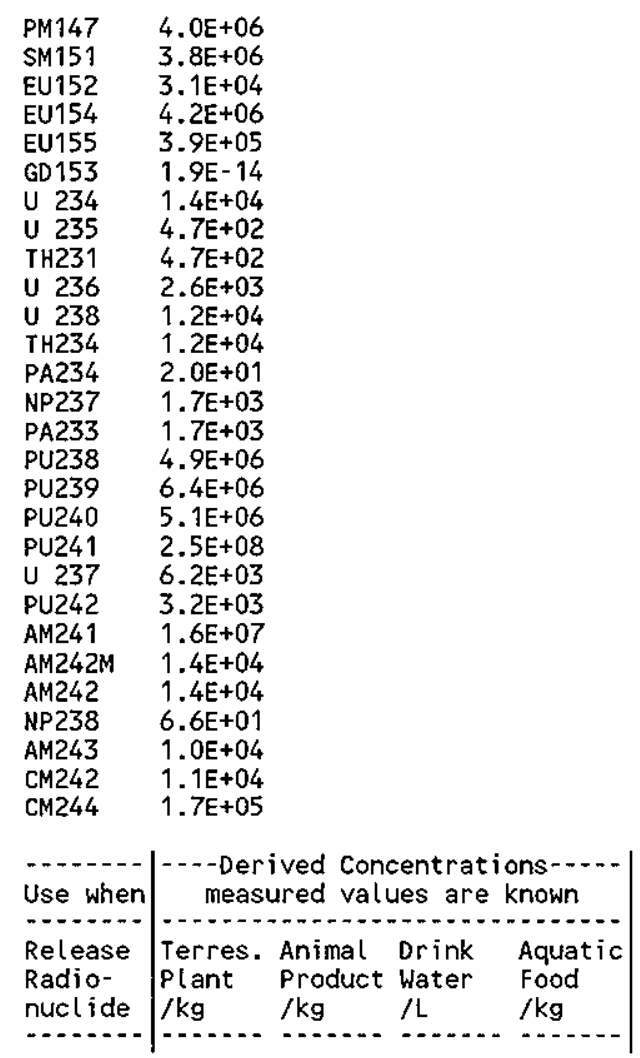

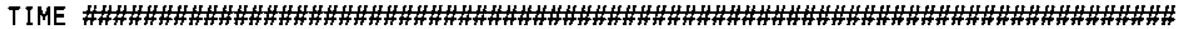

$1 \quad$ Intake ends after (yr)

50 Dose calc. ends after (yr)

0 Release ends after (yr)

0 No. of years of air deposition prior to the intake period

0 No. of years of irrigation water deposition prior to the intake period

FAR-FIELD SCENARIOS (IF POPULATION DOSE)

0 Definition option: 1-Use population grid in file POP.IN

$0 \quad 2$-Use total entered on this line

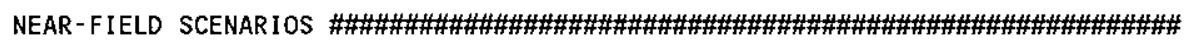



$====$ SURFACE WATER TRANSPORT==========================SECTION $2=====$ Mixing ratio model: 0 -use value, 1 -river, 2 -lake Mixing ratio, dimensionless

Average river flow rate for: MIXFLG $=0(\mathrm{~m} 3 / \mathrm{s})$, MIXFLG $=1,2(\mathrm{~m} / \mathrm{s})$,

Transit time to irrigation withdrawal location (hr)

If mixing ratio model $>0$ : 


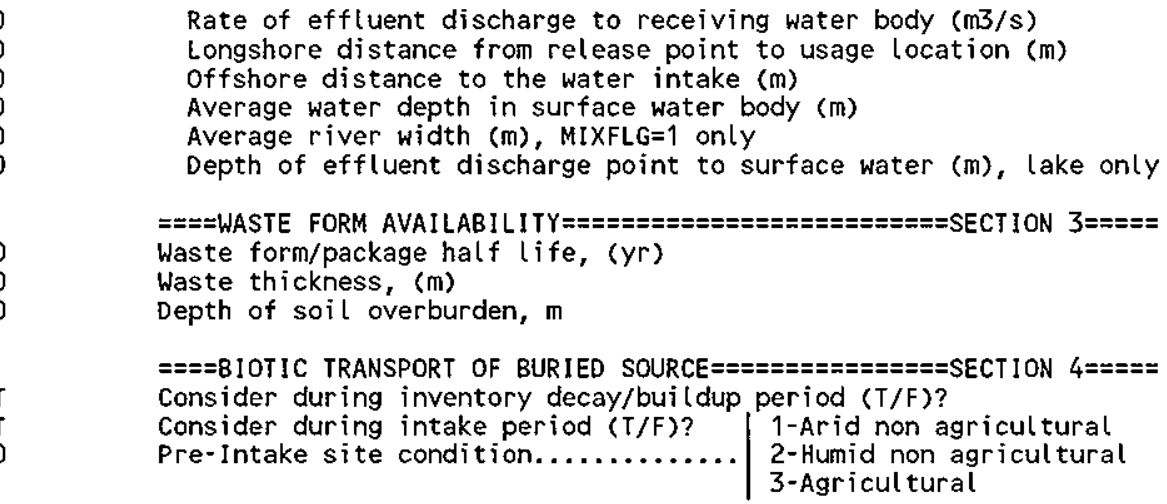



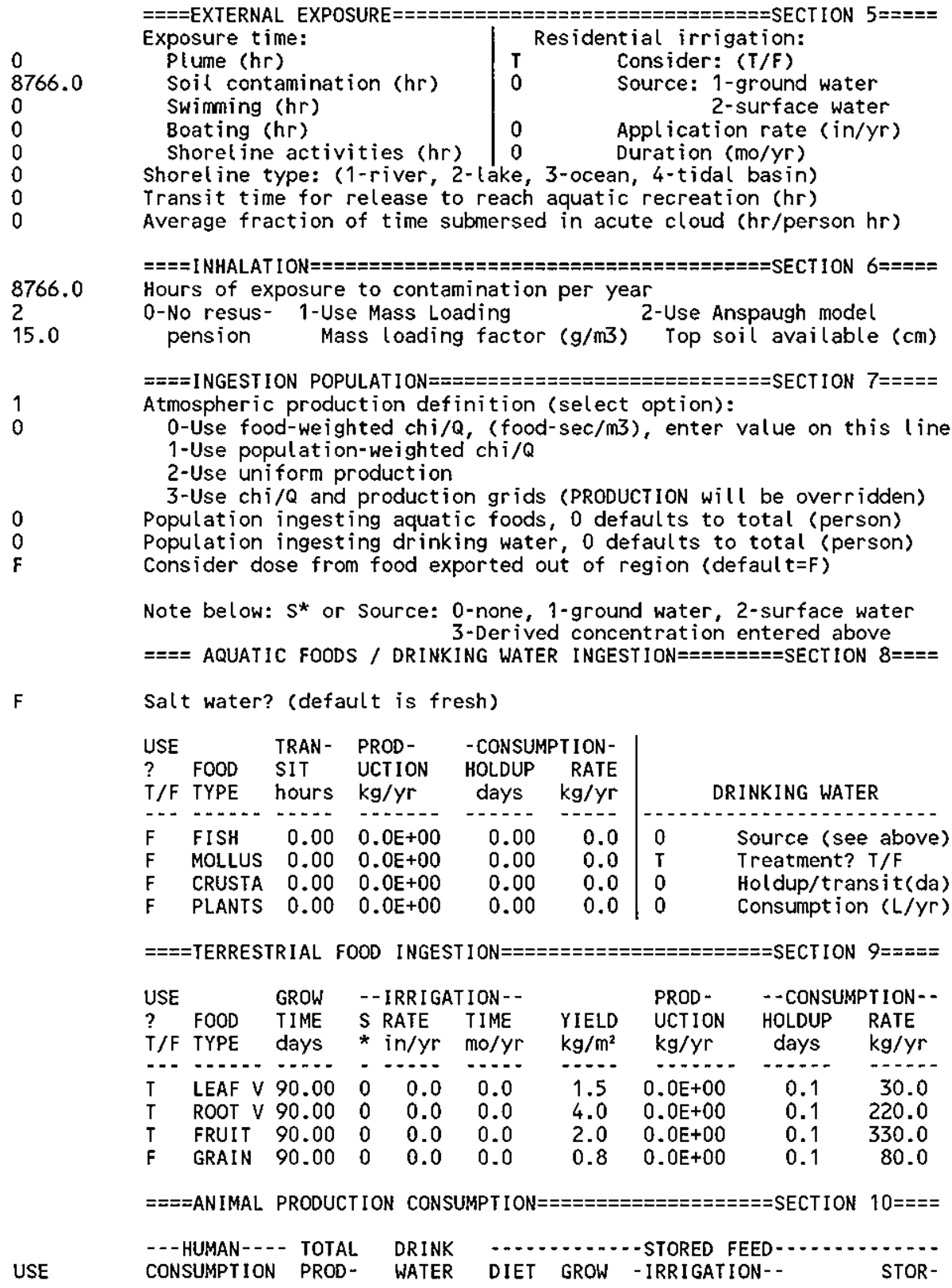




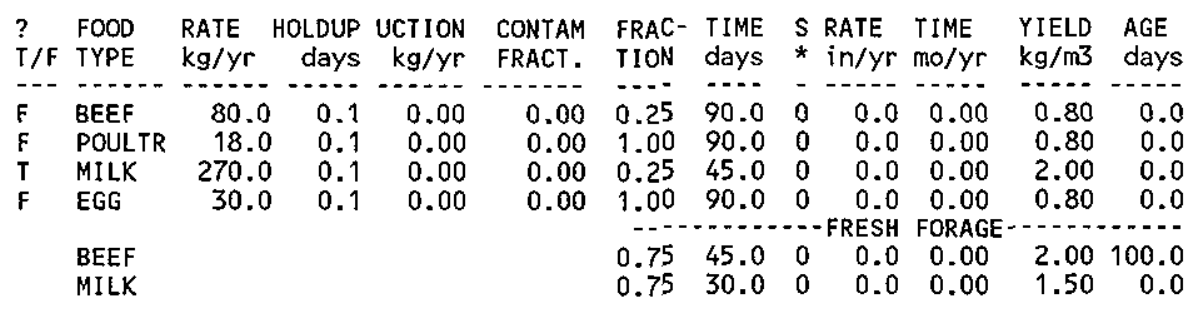

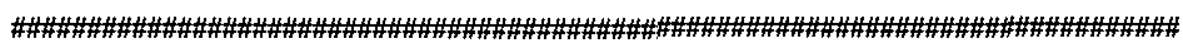




\section{Input File for GENII -- Vegetable Dose Factors}


Title: Veggie Produce IGENII $\backslash 24 P$. IN

Created on $01-06-1998$ at $07: 30$

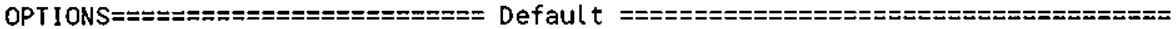

$F$ Near-field scenario? (Far-field) NEAR-FIELD: narrowly-focused

F Population dose? (Individual)

T Acute release? (Chronic) Maximum Individual data set used release, single site Complete TRANSPORT OPTIONS============ Section

$\begin{array}{lll}\text { T Air Transport } & 1 \\ \text { F Surface Water Transport } & 2 \\ \text { F Biotic Transport (near-field) } & 3,4 \\ \text { F Waste Form Degradation (near) } & 3,4\end{array}$ REPORT OPTIONS======================= $T$ Report AEDE only

F Report by radionuclide

i Report by exposure pathway

$F$ Debug report on screen

FAR-FIELD: wide-scale release, multiple sites Complete EXPOSURE PATHWAY OPTIONS===== Section $F$ Finite plume, external 5

F Infinite plume, external 5

$F$ Ground, externál 5

F Recreation, external

$F$ Inhalation uptake

$F$ Drinking water ingestion 7,8

$F$ Aquatic foods ingestion 7,8

$T$ Terrestrial foods ingestion 7,9

F Animal product ingestion 7,10

$F$ Inadvertent soil ingestion

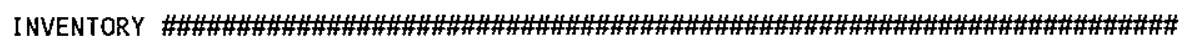

5 Inventory input activity units: ( $1-\mathrm{pCi} \quad 2-\mu \mathrm{Ci} \quad 3-\mathrm{mCi} \quad 4-\mathrm{Ci} \quad 5-\mathrm{Bq}$ )

0 Surface soil source units $\left(1-\mathrm{m}^{2} 2-\mathrm{m} 33-\mathrm{kg}\right)$

Equilibrium question goes here

\begin{tabular}{|c|c|c|c|c|c|c|c|c|}
\hline Use when & tr & $\begin{array}{l}\text { ease Ter } \\
\text { port sel }\end{array}$ & ms & & $\begin{array}{l}\text {--Basic } \\
\text { ield sce }\end{array}$ & $\begin{array}{l}\text { Conc } \\
\text { enari }\end{array}$ & opt 1or & \\
\hline $\begin{array}{l}\text { Release } \\
\text { Radio- } \\
\text { nucl ide }\end{array}$ & $\begin{array}{l}\text { Air } \\
\text { /yr }\end{array}$ & $\begin{array}{l}\text { Surface } \\
\text { Water } \\
\text { /yr }\end{array}$ & $\begin{array}{l}\text { Buried } \\
\text { Waste } \\
/ \mathrm{m} 3\end{array}$ & $\begin{array}{l}\mathrm{Air} \\
/ \mathrm{m} 3\end{array}$ & $\begin{array}{l}\text { Surface } \\
\text { Soil } \\
\text { /unit }\end{array}$ & $\begin{array}{l}\text { Deep } \\
\text { Soil } \\
/ \mathrm{m} 3\end{array}$ & $\begin{array}{l}\text { Ground } \\
\text { Water } \\
\text { /L }\end{array}$ & $\begin{array}{l}\text { Surface } \\
\text { Water } \\
\text { /L }\end{array}$ \\
\hline
\end{tabular}

$\begin{array}{ll}\text { H } 3 & 9.7 E+05\end{array}$

C $14 \quad 2.0 E+04$

FE55 2.0E+04

C060 $\quad 7.7 \mathrm{E}+04$

NI59 $1.2 \mathrm{E}+03$

NI63 1.3E+05

SE79 2.4E+03

KR85 $1.4 \mathrm{E}+07$

SR90 2.6E+08

Y $90 \quad 2.6 \mathrm{E}+08$

ZR93 1.1E+04

NB93M 7.1E+03

TC99 8.1E+04

RU106 $9.5 E+02$

PD107 5.8E+02

AG110M 2.0E-03

CD113M 1.0E+05

SN113 5.0E-15

IN113M 5.0E-15

SN119M 2.3E-03

SN121M $2.3 E+03$

SN121 1.8E+03

SN123 6.4E-12

SN126 4.8E+03

SB126M $\quad 4.8 E+03$

SB126 $6.7 E+02$

TE123M 5.6E-17

TE 127M 8.0E-15

TE127 7.8E-15

I $129 \quad 1.9 \mathrm{E}+02$

CS134 $2.4 \mathrm{E}+05$

CS135 2.2E+03

CS137 $3.6 \mathrm{E}+08$

CE144 2.9E+01

PR144M 3.5E-01

PR144 2.9E+01

PM147 4.0E+06 
HNF-SD-SNF-TI-059 REV 2

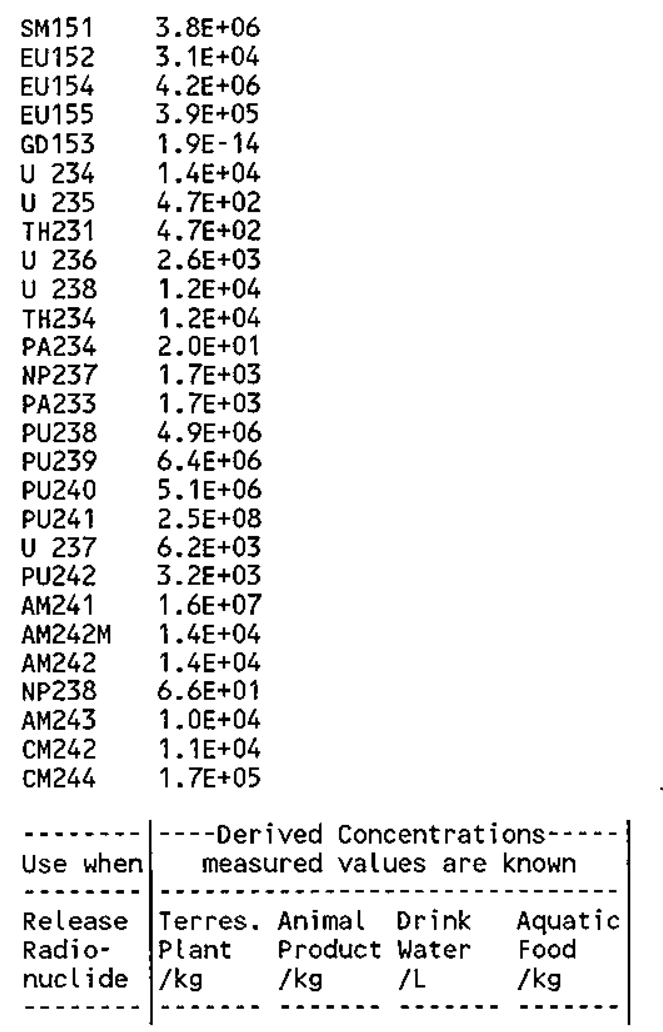



$1 \quad$ Intake ends after $(y r)$

50 Dose calc. ends after $(y r)$

0 Release ends after ( $y r)$

0 No. of years of air deposition prior to the intake period

0 No. of years of irrigation water deposition prior to the intake period

FAR-FIELO SCENARIOS (IF POPULATION DOSE)

0 Definition option: 1-Use population grid in file POP.IN

0 2-Use total entered on this line

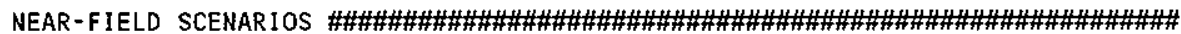

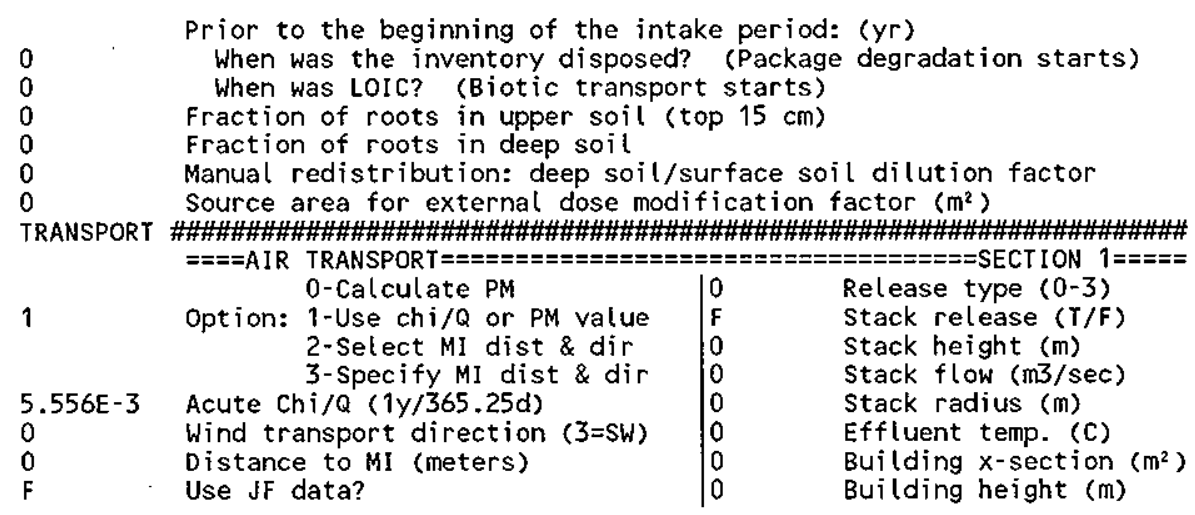



$0 \quad$ Mixing ratio model: 0 -use value, 1-river, 2-lake

0 . Mixing ratio, dimensionless

0 Average river flow rate for: MIXFLG $=0(\mathrm{mB} / \mathrm{s}), \operatorname{MIXFLG}=1,2(\mathrm{~m} / \mathrm{s})$,

$0 \quad$ Transit time to irrigation withdrawal location $(\mathrm{hr})$

If mixing ratio model $>0$ :

0 Rate of effluent discharge to receiving water body $(\mathrm{m} 3 / \mathrm{s})$ 
Longshore distance from release point to usage location (m) offshore distance to the water intake (m)

Average water depth in surface water body (m)

Average river width $(m), M I X F L G=1$ only

Depth of effluent discharge point to surface water (m), lake only

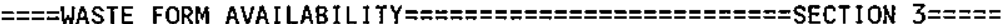

Waste form/package half life, (yr)

Waste thickness, (m)

Depth of soil overburden, m

$====$ BIOTIC TRANSPORT OF BURIED SOURCE $===============$ SECTION $4====$ Consider during inventory decay/buildup period (T/F)?

Consider during intake period (T/F)? 1-Arid non agricultural

Pre-Intake site condition............ 2-Humid non agricultural

3-Agricultural

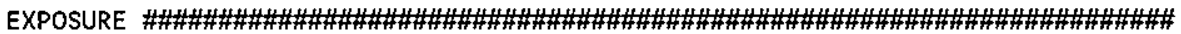

0
8766.0
0
0
0
0
0
0

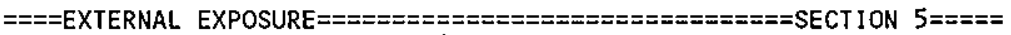
Exposure time:

Plume (hr)

Soil contamination (hr)

Swimming (hr)

Boating (hr)

Residential irrigation:

Shorel ine act

ivities (hr)

Transit time for release to reach aquatic recreation (hr)

Average fraction of time submersed in acute cloud (hr/person $h r$ )

8766.0 Hours of exposure to contamination per year

2

0 -No resus- 1-Use Mass Loading

2-Use Anspaugh model

pension

Mass loading factor $(\mathrm{g} / \mathrm{m} 3)$

Top soil available (cm)

1

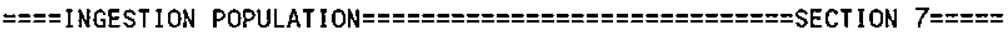

Atmospheric production definition (select option):

0 -Use food-weighted chi/Q, (food-sec/m3), enter value on this line

1-Use population-weighted $\mathrm{ch} \mathrm{i} / \mathrm{Q}$

2-Use uniform production

3-Use chi/Q and production grids (PRODUCTION will be overridden)

Population ingesting aquatic foods, 0 defaults to total (person)

Population ingesting drinking water, 0 defaults to total (person)

consider dose from food exported out of region (default $=F$ )

Note below: $S^{*}$ or Source: 0-none, 1-ground water, 2-surface water

3-Derived concentration entered above

$====$ AQUATIC FOODS / DRINKING WATER INGESTION $========$ SECTION $8====$

F Salt water? (default is fresh)

\begin{tabular}{|c|c|c|c|c|c|c|}
\hline $\begin{array}{l}\text { USE } \\
? \\
T / F\end{array}$ & $\begin{array}{l}\text { FOOD } \\
\text { TYPE }\end{array}$ & $\begin{array}{l}\text { TRAN- } \\
\text { SIT } \\
\text { hours }\end{array}$ & $\begin{array}{l}\text { PROD- } \\
\text { UCT ION } \\
\mathrm{kg} / \mathrm{Yr}\end{array}$ & $\begin{array}{l}\text { - CONSUM } \\
\text { HOLDUP } \\
\text { days }\end{array}$ & $\begin{array}{r}\text { TION- } \\
\text { RATE } \\
\mathrm{kg} / \mathrm{yr}\end{array}$ & DRINKING WATER \\
\hline--- & ----- & & & $-\ldots$ & & \\
\hline & FISH & 0.00 & $0.0 E+00$ & 0.00 & 0.0 & Source (see above) \\
\hline & MOLLUS & 0.00 & $0.0 E+00$ & 0.00 & 0.0 & Treatment? T/F \\
\hline 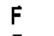 & CRUSTA & 0.00 & $0.0 \varepsilon+00$ & 0.00 & 0.0 & Holdup/transit (da) \\
\hline 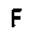 & PLANTS & 0.00 & $0.0 E+00$ & 0.00 & 0.0 & Consumption (L/Yr) \\
\hline
\end{tabular}

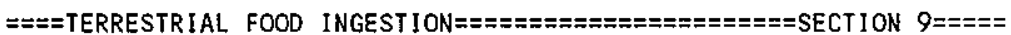

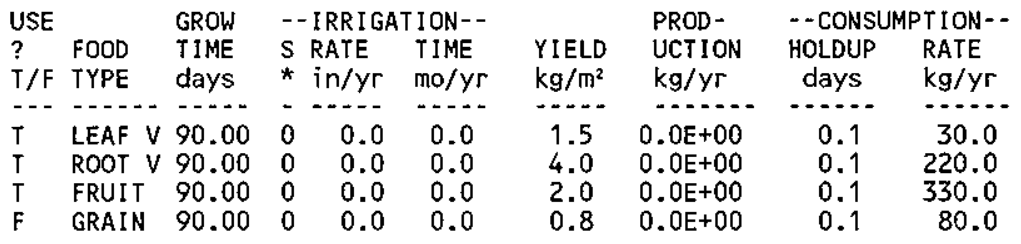

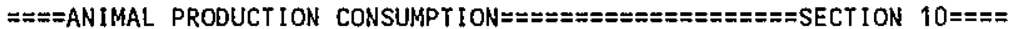

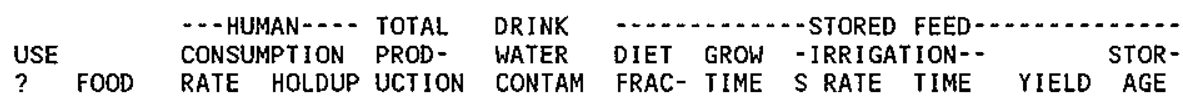




\section{HNF-SD-SNF-TI-059 REV 2}

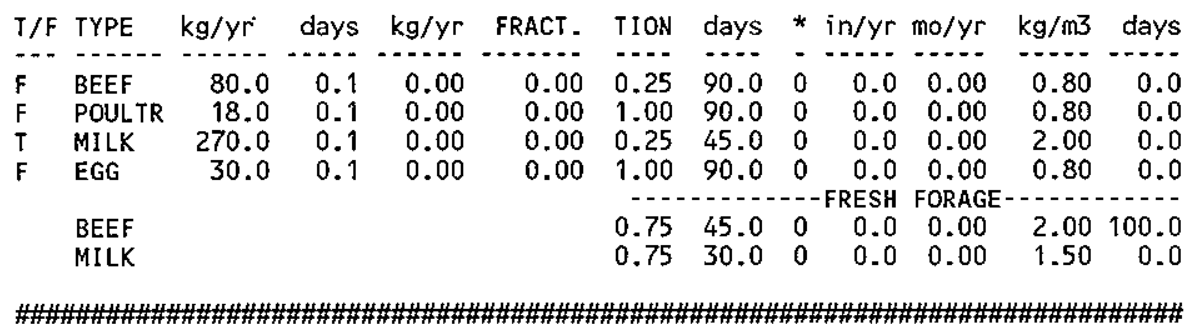


HNF-SD-SNF-TI-059 REV 2

APPENDIX H

CHECKLISTS FOR PEER REVIEW AND APPROVAL 
HNF-SD-SNF-TI-059 REV 2

This page intentionally left blank. 


\section{CHECKLIST FOR TECHNICAL PEER REVIEW}

Document Reviewed: HNF - SD-SNF-TI-OSq RCV 2

Title:

Author: P. Q RittmanN

Date: $\quad B / 12 / 9 \mathrm{~g}$

Scope of Review: Revucd X/Qs + Orgon Dorse Cacculations

Yes $\mathrm{No}^{*} \mathrm{NA}$

$\{X][]^{* *}$ Previous reviews complete and cover analysis, up to scope of this review, with no gaps.

[X][ ][ ] Problem completely defined.

[ ] [ $][x]$ Accident scenarios developed in a clear and logical manner.

(x] [ ] [ ] Necessary assumptions explicitly stated and supported.

XI ] [ ] Computer codes and data files documented.

X] ] [ ]

X][ ][ ]

[][]$[x]$

$x][][]$

Data used in calculations explicitly stated in dosument.

Data checked for consistency with original source information as applicable.

Mathematical derivations checked inciuding dimensional consistency of results.

Models appropriate and used within range of validity or use outside range of established validity justified.

$[X][$ ] ] Hand calculations checked for errors. Spreadsheet results should be treated exactly the same as hand calculations.

$[\times][][]$

X][ ][]

Software input correct and consistent with document reviewed.

$\propto][][]$

Software output consistent with input and with results reported in document reviewed.

Limits/criteria/guidelines applied to analysis results are appropriate and referenced.

Limits/criteria/guidelines checked against references.

X][ ] ]

$\triangle][$ ] $]$

$[x][][]$

¿] [ ] ]

Safety margins consistent with good engineering practices.

Conclusions consistent with analytical results and applicable limits.

Results and conclusions address all points required in the problem statement.

Format consistent with applicable guides or other standards.

[ ] $[x]^{* *}$

$X][][]$

Review calculations, comments, and/or notes are attached.

Traceability

[X] [ ] [ ] Document approved (for example, the reviewer affirms the technical accuracy of the document).

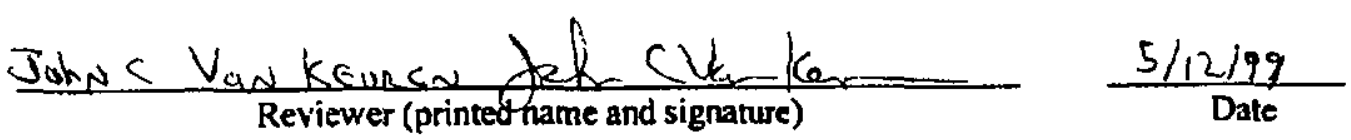

- All "no" responses must be explained below or on an additional sheet.

** Any calculations, comments, or notes generated as part of this review should be signed, dated, and attached to this checklist. Such material should be labeled and recorded in such a manner as to be intelligible to a technically qualified third party. 


\section{HEDOP REVIEW CHECKAIST}

Document Reviewed: HNR-SD-SNF-.OSP REV 2

Title:

Author: P. D RithmanN

Date: $5 / 12 / 99$

Scope of Review: Reviscd X/Qs t Organ Dose Cquculations

Yes No* NA

$[\zeta[][] \quad$ 1. A detailed technical review and approval of the environmental transport and dose calculation portion of the aralysis has been performed and documented.

[ I I J

2. Detailed technical review(s) and approval(s) of scenario and release determinations have been performed and documented.

[ ] ] ]

3. HEDOP-approved code(s) were used.

[ ] ] [ /

4. Receptor locations were selected according to HEDOP recommendations.

[以] ] ]

5. All applicable environmental pathways and code options were included and are appropriate for the calculations.

[

6. Hanford site data were used.

[ut ] ] ]

7. Model adjustments external to the computer program were justified and performed correctly.

[ ] ] [ [

8. The analysis is consistent with HEDOP recommendations.

[ ] ] ] U

9. Supporting notes, calculations, comments, comment resolutions, or other information is attached. (Use the "Page 1 of $X$ " page numbering format and sign and date each added page.)

[U] ] ] 10. Approval is granted on behalf of the Hanford Environmental Dose Overview Pancl.

- All "ro" responses must be explained below or on an additional sheet.
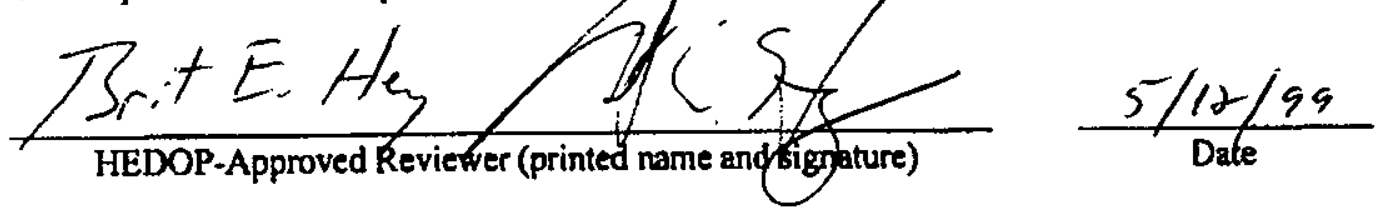

COMMENTS (add additional signed and dated page if necessary): 